\title{
EXTRAÇÃO SEQÜENCIAL E ESPECIAÇÃO IÔNICA DE ZINCO, COBRE E CÁDMIO EM LATOSSOLOS TRATADOS COM BIOSSÓLIDO
}

\section{MARIA LUCIA AZEVEDO SILVEIRA}

\begin{abstract}
Tese apresentada à Escola Superior de Agricultura "Luiz de Queiroz", Universidade de São Paulo, para obtenção do título de Doutor em Agronomia, Área de Concentração: Solos e Nutrição de Plantas.
\end{abstract}

P I R A C I C A B A

Estado de São Paulo - Brasil

Dezembro - 2002 


\title{
EXTRAÇÃO SEQÜENCIAL E ESPECIAÇÃO IÔNICA DE ZINCO, COBRE E CÁDMIO EM LATOSSOLOS TRATADOS COM BIOSSÓLIDO
}

\author{
MARIA LUCIA AZEVEDO SILVEIRA \\ Engenheira Agrônoma
}

Orientador: Prof. Dr. Luís Reynaldo Ferracciú Alleoni

Tese apresentada à Escola Superior de Agricultura "Luiz de Queiroz", Universidade de São Paulo, para obtenção do título de Doutor em Agronomia, Área de Concentração: Solos e Nutrição de Plantas.

P I R A C I C A B A

Estado de São Paulo - Brasil

Dezembro - 2002 


\title{
Dados Internacionais de Catalogação na Publicação (CIP)
}

DIVISÃO DE BIBLIOTECA E DOCUMENTAÇÃO - ESALQ/USP

\author{
Silveira, Maria Lucia Azevedo \\ Extra ção seqüencial e especia liza ção iônica de zinco, cobre e cádmio \\ em la tossolostratados com biossólido / Maria Lucia Azevedo Silveira. - - \\ Piracicaba, 2002. \\ 166 p. : il. \\ Tese (doutora do) - Escola Superior de Agric ultura Luiz de Queiroz, 2002. \\ Bibliografia. \\ 1. Cádmio 2. Cobre 3. Especiação químic a 4. Latossolo 5. Lodo de esgoto \\ 6. Metal pesa do 7. Znco I. Título
}

CDD 631.44 


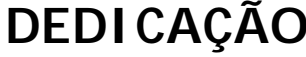

Aos meus pais, Lourdes e Iosé Waldir, pelo apoio, amor e o incentivo que me motivou a transpor todos os desafios. 


\section{Agradecimentos}

Ao Prof. Dr. Luís Reynaldo Ferracciú Alleoni, pela orientação, confiança e amizade;

Ao Prof. Dr. Andrew Chang (Universidade da Califórnia- Riverside) pela orientação no exterior e apoio;

Ao Dr. Ronaldo S. Berton (Instituto Agronômico de Campinas), pelo auxílio na elaboração do projeto e apoio técnico;

Ao Dr. Albert Page (Universidade da Califórnia- Riverside), pelas críticas e sugestões;

À CAPES, pela concessão da Bolsa de estudo;

À coordenação do Curso de Pós-Graduação em Solos e Nutrição de Plantas (ESALQ/USP), pela oportunidade oferecida;

Á Universidade da Califórnia- Riverside, pela oportunidade de realização do doutorado com estágio no exterior;

Aos funcionários da Universidade da Califórnia e da ESALQ, pelo auxílio nas análises laboratoriais;

Aos colegas de curso, pela amizade e convivência;

A todos aqueles que direta ou indiretamente ajudaram na realização desse trabalho; 


\section{SUMÁRIO}

Página

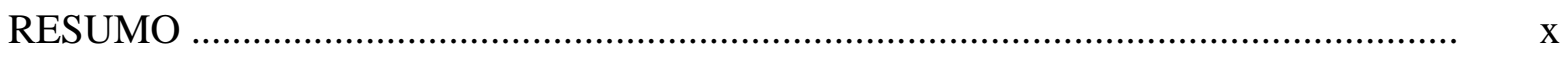

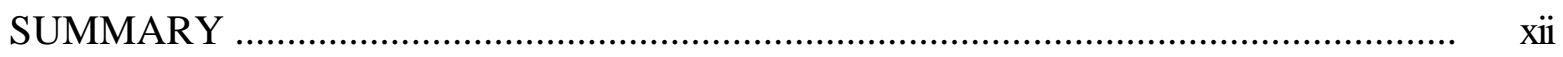

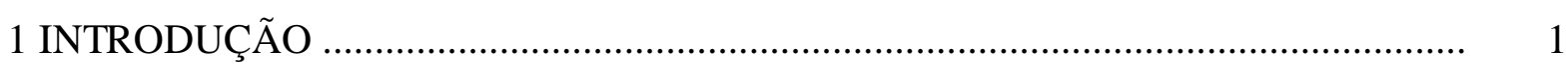

2 REVISÃO DE LITERATURA ....................................................................... 7

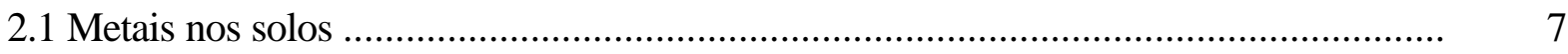

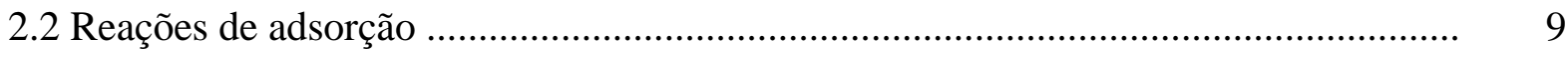

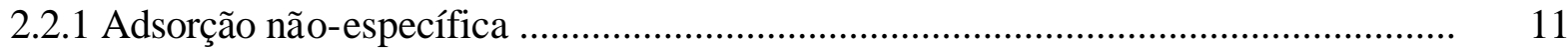

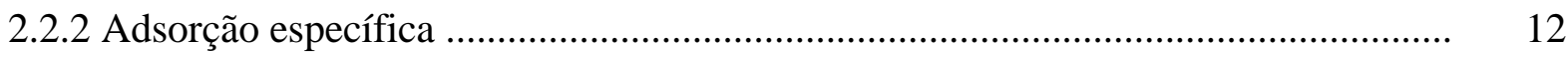

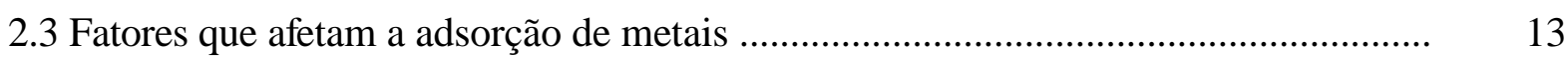

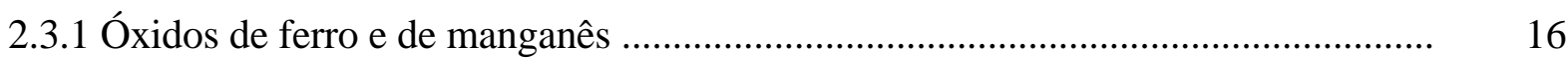

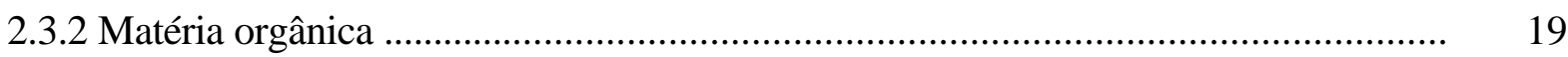

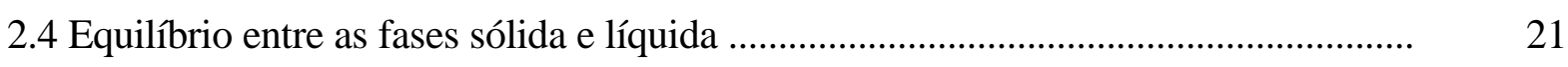

3 MODIFICAÇÃO NO MÉTODO DE EXTRAÇÃO SEQÜENCIAL DE METAIS 27 PARA LATOSSOLOS E BIOSSÓLIDOS

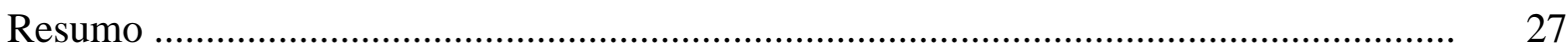

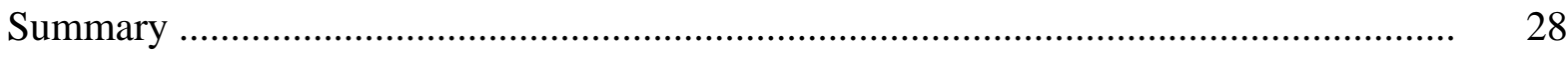

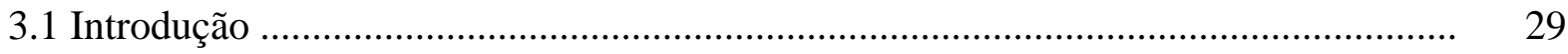

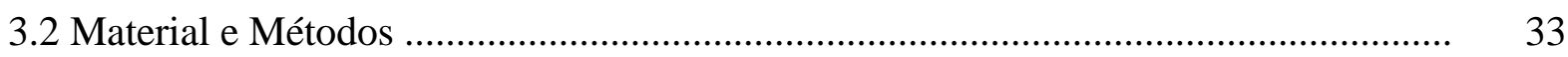

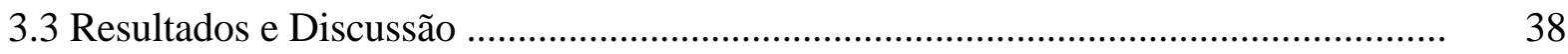

3.3.1 Efeito da concentração da solução de $\mathrm{NH}_{2} \mathrm{OH} . \mathrm{HCl}$ na dissolução de óxidos de $\mathrm{Mn} \quad 39$

3.3.2 Extração dos óxidos de Fe cristalinos e mal-cristalizados ...................................... 41

3.3.3 Recuperação de $\mathrm{Zn}, \mathrm{Cu}$ e $\mathrm{Cd}$ nas amostras que submetidas a extração seqüencial .. $\quad 48$

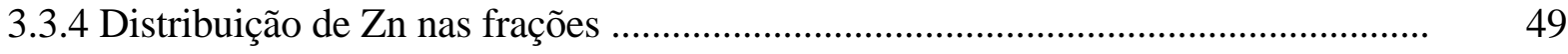


3.3.5 Distribuição de $\mathrm{Cu}$ nas frações ............................................................................

3.3.6 Distribuição de Cd nas frações .................................................................................

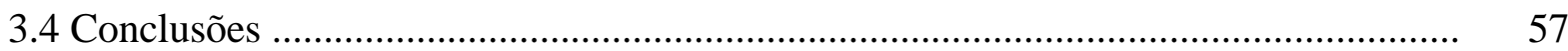

4 EFEITO DO pH E DA FORÇA IÔNICA NA ESPECIAÇÃO IÔNICA E NA 59 DISTRIBUIÇÃO DE ZINCO, COBRE E CÁDMIO EM AMOSTRAS DE LATOSSOLOS E DE BIOSSÓLIDOS

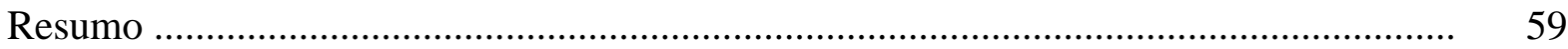

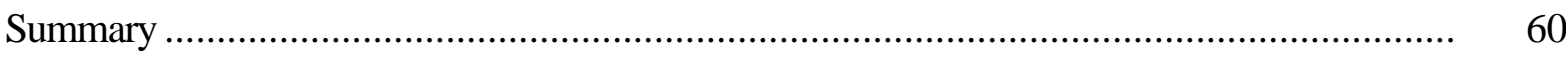

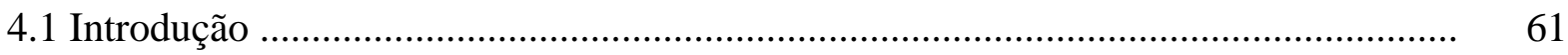

4.1.1 Reações que controlam a disponibilidade de metais no solo .................................... 62

4.1.2 Distribuição dos metais na fase sólida ...................................................................... 65

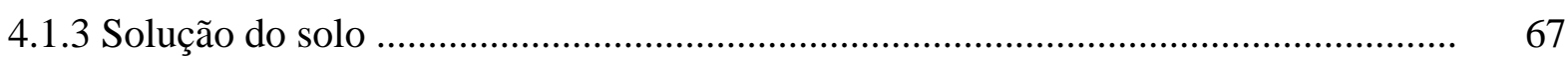

4.1.4 Limites tóxicos para aplicação de biossólidos ……………………………………....... 68

4.2 Material e Métodos ................................................................................................

4.2.1 Aparato Experimental ..................................................................................

4.2.2 Atividade química de metais em solos tratados com biossólidos ...............................

4.2.3 Efeito da acidez do solo ....................................................................................

4.2.4 Efeito da variação na força iônica da solução .......................................................... $\quad 78$

4.3 Resultados e Discussão .......................................................................................

4.3.1 Recuperação de metais nas amostras ..................................................................... $\quad 78$

4.3.2 Efeito do $\mathrm{pH}$ e da força iônica na distribuição dos metais nas fases sólida e

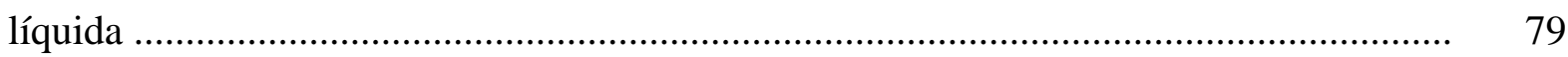

4.3.3 Distribuição de Zn nas amostras .........................................................................

4.3.4 Distribuição de $\mathrm{Cu}$ nas amostras ......................................................................... 91

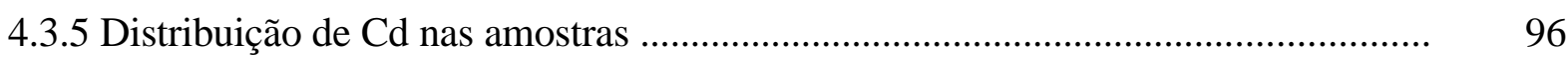

4.3.6 Especiação dos metais em solução ...................................................................... 103

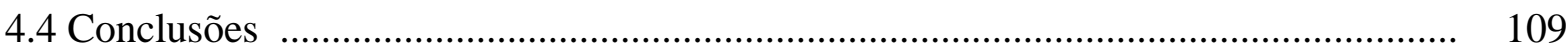

5 CONDICIONADORES QUÍMICOS NA RETENÇÃO E DISTRIBUIÇÃO DE METAIS PESADOS EM LATOSSOLOS E EM BIOSSÓLIDO ...................................... 110

Resumo ..................................................................................................... 110

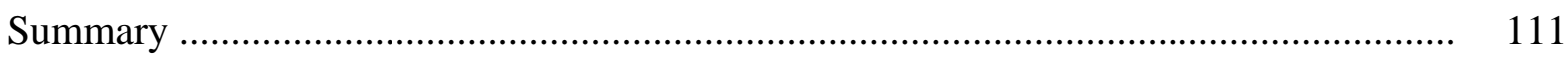

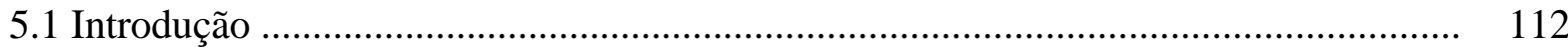




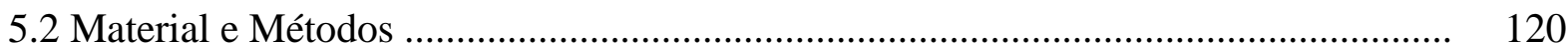

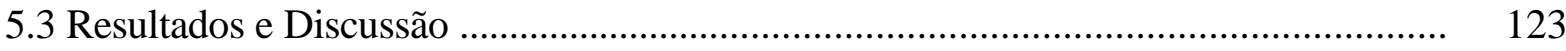

5.3.1 Efeito da dose de HA e do modo de tratamento das amostras ................................. 123

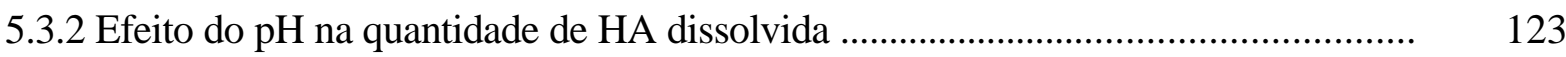

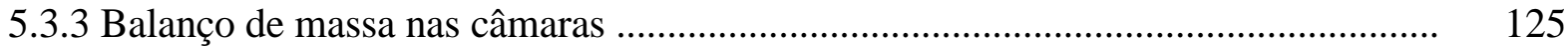

5.3.4 Distribuição dos metais nas fases sólida e líquida após o equilíbrio nas câmaras ... $\quad 126$

5.3.5 Efeito dos condicionadores na retenção dos metais no biossólido ........................... 130

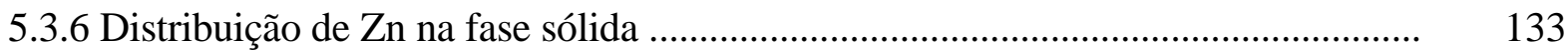

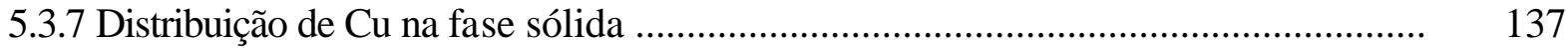

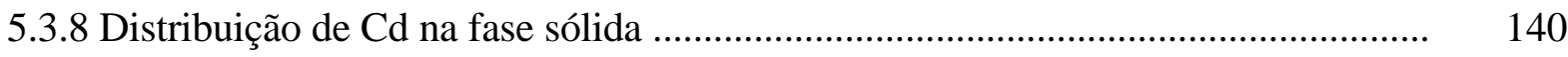

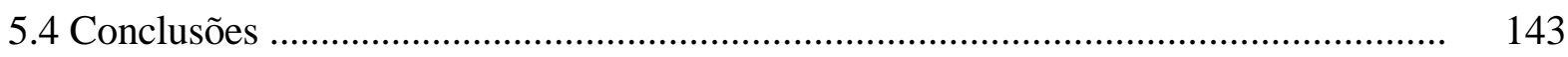

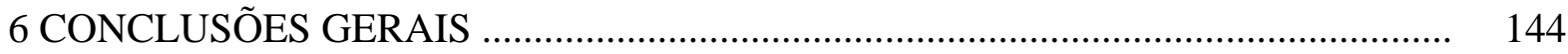

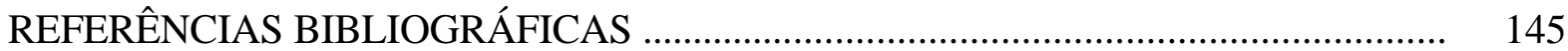




\section{LISTA DE FIGURAS}

Página

1 Tipos de interação entre as fases sólida e líquida do solo ........................................ 8

2 Remoção de óxidos de Fe, após cinco extrações seqüenciais ............................... 45

3 Resultados do difratograma de raios- $\mathrm{X}$ nas amostras de terra originais e tratadas com ditionito de sódio (T1) e oxalato $+\mathrm{HCl}(\mathrm{T} 2+\mathrm{T} 3)$........................................... 47

4 Distribuição de Zn nos solos e nos biossólidos .................................................... 50

5 Distribuiçãa de $\mathrm{Cu}$ nos solos e nos biossólidos ...................................................... 54

6 Distribuiç̧ão de Cd nos solos e nos biossólidos .................................................... 56

7 Dinâmica das reações de equilíbrio de metais nos solos ............................................ 63

8 Formas de metais nos solos potencialmente tóxicas no solo ................................ 64

9 Unidades das câmaras-duplas de difusão e membrana semi-permeável................... 73

10 Conjunto das câmaras-duplas de difusão e sistema de rotação ................................ 73

11 Representação esquemática das câmaras-duplas de difusão .................................. 74

12 Reações que ocorrem com os metais nas câmaras ................................................. 75

13 Distribuição de Zn nas fases sólida (2 g de terra e de biossólido) e líquida (500mL de solução) antes e após o equilíbrio nas câmaras .................................................. 80

14 Distribuição de Cu nas fases sólida (2 g de terra e de biossólido) e líquida (500mL de solução) antes e após o equilíbrio nas câmaras .................................................

15 Distribuição de Cd nas fases sólida (2 g de terra e de biossólido) e líquida (500mL de solução) antes e após o equilíbrio nas câmaras ................................................. 82

16 Extração seqüencial de Zn nas amostras de terra após o equilíbrio nas câmaras ....... 86

17 Extração seqüencial de Zn nas amostras de biossólido após o equilíbrio nas câmaras.

18 Extração sequiencial de $\mathrm{Cu}$ nas amostras de terra após o equilíbrio nas câmaras ....... 92

19 Extração seqüencial de Cu nas amostras de biossólido após o equilíbrio nas 


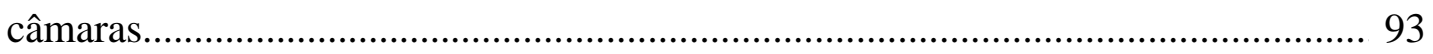

20 Extração seqüencial de Cd nas amostras de terra após o equilíbrio nas câmaras ....... 97

21 Extração seqüencial de Cd nas amostras de biossólido após o equilíbrio nas

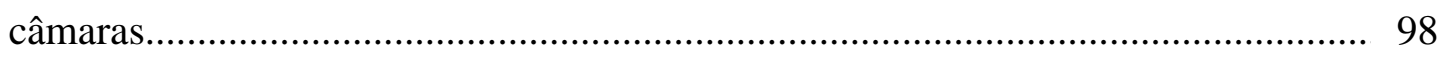

22 Distribuição de Zn, Cu e Cd nas fases sólida (solo e biossólido) e em solução ........ 127

23 Porcentagem dos metais retidos nas amostras de biossólido após equilíbrio com

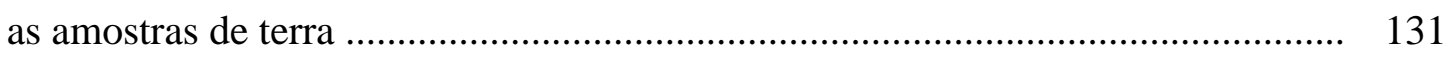

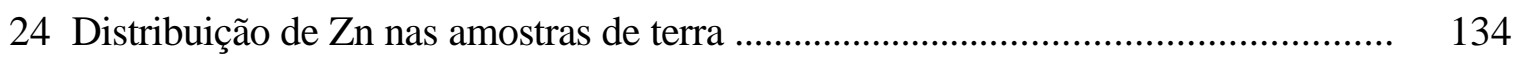

25 Distribuição de Zn nas amostras de biossólido ......................................................... 136

26 Distribuição de $\mathrm{Cu}$ nas amostras de terra ................................................................ 138

27 Distribuição de $\mathrm{Cu}$ nas amostras de biossólido .......................................................... 139

28 Distribuição de $\mathrm{Cu}$ nas amostras de terra ........................................................... 141

29 Distribuição de $\mathrm{Cu}$ nas amostras de biossólido ....................................................... 142 


\section{LISTA DE TABELAS}

Página

1 Ordem de estabilidade dos complexos em diferentes pHs ............................................ 20

2 Principais espécies químicas de elementos traços em soluções de solos ácido 22 alcalino (condições aeróbicas)

3 Representação de ácidos e bases duras e moles ........................................................... 24

4 Atributos químicos e físicos das amostras de terra ………………………………........ 34

5 Teores de óxidos (totais, livres e mal-cristalizados) ………………………………….... 35

6 Concentração total de Zn, Cu e Cd nas amostras ........................................................ 35

7 Valores médios de $\mathrm{Fe}, \mathrm{Zn}$ e $\mathrm{Mn}$ deslocados após 30 minutos de tratamento com $\mathrm{NH}_{2} \mathrm{OH} . \mathrm{HCl}$ ajustado a pH 2 ............................................................................ 40

8 Métodos para extração de óxidos de $\mathrm{Fe}$......................................................................... 42

9 Quantidade de Fe extraída a partir dos métodos .......................................................... 43

10 Recuperação dos metais após a extração seqüencial ................................................... 48

11 Propriedades de alguns cátions ............................................................................... 66

12 Concentração de Zn, Cu e Cd nas amostras ............................................................... 71

13 Esquema de extração seqüencial de metais ................................................................. 76

14 Recuperação dos metais nas amostras ................................................................... 78

15 Especiação iônica da solução após o equilíbrio nas câmaras-duplas de difusão ........... 104

16 Quantidade de $\mathrm{Zn}$, em $\mu \mathrm{g}$, nas amostras de terra tratadas com hidroxiapatita (HA) .... 124

17 Especiação química da solução eletrolítica após a adição da HA ................................. 124

18 Balanço de massa nas câmaras .............................................................................. 125 


\title{
EXTRAÇÃO SEQÜENCIAL E ESPECIAÇÃO IÔNICA DE ZINCO, COBRE E CÁDMIO EM LATOSSOLOS TRATADOS COM BIOSSÓLIDO
}

\author{
Autora: MARIA LUCIA AZEVEDO SILVEIRA \\ Orientador: Prof. Dr. LUÍS REYNALDO FERRACCIÚ ALLEONI
}

\section{RESUMO}

Com o crescimento urbano e industrial houve considerável aumento na geração de resíduos, tais como os biossólidos provenientes de estações de tratamento de esgoto. Diversas estratégias de utilização desse resíduo tem sido propostas, e o uso agrícola como fertilizante tem se tornado prática comum. Entretanto, os biossólidos podem apresentar caráter poluente, dependendo, dentre outro fatores, dos níveis de metais pesados no resíduo. A concentração total de metais nos solos pode ser utilizada como indicativo dos efeitos da aplicação agrícola de biossólidos, porém pode não refletir sua biodisponibilidade. A determinação das espécies em solução, bem como a distribuição dos metais na fase sólida, obtida por meio da extração sequiencial, são ferramentas úteis para avaliar as mudanças no comportamento desses elementos nos solos em resposta à aplicação de biossólidos. Os objetivos desse trabalho foram adaptar um método de extração seqüencial adequado para Latossolos tratados com biossólidos; avaliar o efeito do pH e da força iônica na retenção e distribuição de $\mathrm{Zn}, \mathrm{Cu}$ e Cd nas fases sólidas (solo e biossólido) e em solução; testar os efeitos de condicionadores químicos de solo, na imobilização de metais. A modificação do método de extração seqüencial de metais foi adequado para obter a distribuição de $\mathrm{Zn}, \mathrm{Cu}$ e $\mathrm{Cd}$ em Latossolos e biossólidos. Nas amostras originais de solo, o $\mathrm{Zn} \mathrm{e} \mathrm{o} \mathrm{Cu}$ estavam 
presentes em frações pouco móveis (residual e ligado aos óxidos de $\mathrm{Fe}$ ), enquanto o $\mathrm{Cd}$ foi encontrado ligado, principalmente, às superfícies dos óxidos. Nos biossólidos, os óxidos de $\mathrm{Mn}$ e de Fe tiveram papel importante na retenção de metais. A redução do $\mathrm{pH}$ da solução ocasionou aumento na quantidade de metais em solução, sobretudo nas formas livres, e na fração trocável nos solos. Esse efeito foi mais acentuado para $\mathrm{Zn}$ e $\mathrm{Cd}$, em relação ao $\mathrm{Cu}$. $\mathrm{O}$ efeito da força iônica não foi acentuado. Os condicionadores de solos foram eficientes na imobilização de $\mathrm{Zn}, \mathrm{Cu}$ e $\mathrm{Cd}$, porém a elevação do pH favoreceu a redução na concentração de metais em solução ou ligados à fração prontamente disponível (trocável). Em contrapartida, a quantidade de metais ligados à fração carbonatos/superfície dos óxidos foi aumentada com o uso dos condicionadores. Em geral, o uso do $\mathrm{CaCO}_{3}$ (pH 7) promoveu a menor disponibilização de metais do biossólido para solução. 


\title{
SEQUENTIAL EXTRACTION AND IONIC SPECIATION OF ZINC, COPPER AND CADMIUM IN OXISOLS AMENDED WITH BIOSOLID
}

\author{
Author: MARIA LUCIA AZEVEDO SILVEIRA \\ Adviser: Prof. Dr. LUÍS REYNALDO FERRACCIÚ ALLEONI
}

\section{SUMMARY}

The production of residues such as biosolids has been increased in urban and industrial societies. Many alternatives of their disposal have been proposed, and the agricultural application as a fertilizer has been more common. However, depending on the heavy metal contents, the biosolids may have a toxic effect in the environment. The metal total concentration in soils is an indicative related to the effects of agricultural application of biosolids, even though, it can not reflect their bioavailability. The determination of the species in solution, as well as the distribution of the metals in the solid phase, using the sequential extraction method, are useful tools for evaluating the changes in the metal behavior in the soils in response to the biosolid application. The objectives of this work were to: (i) develop a method of sequential extraction suitable for Oxisols treated with biosolids; (ii) evaluate the $\mathrm{pH}$ and the ionic strenght effect on the retention and distribution of $\mathrm{Zn}, \mathrm{Cu}$ and $\mathrm{Cd}$ in the solid phases (soil and biosolid) and on the solution; to test the efficiency of different amendments in the immobilization of metals. The modified sequential extraction procedure was appropriate to assess $\mathrm{Zn}, \mathrm{Cu}$ and $\mathrm{Cd}$ distribution in Oxisols and biosolids. In the original samples, $\mathrm{Zn}$ and $\mathrm{Cu}$ were associated with non-mobile fractions (residual and iron oxides), while $\mathrm{Cd}$ was found to be related with surface oxides fraction. The $\mathrm{Mn}$ and $\mathrm{Fe}$ oxide fractions played an important role in the metal retention by biosolids. As $\mathrm{pH}$ decreased, an increase in the metal concentrations in solution was observed, mainly as free-ions, and associated with the exchangeable fraction in the soils. The effect was more evident for $\mathrm{Zn}$ and $\mathrm{Cd}$, 
comparing to $\mathrm{Cu}$. The effect of the ionic force was not pronounced. The amendments were efficient in the immobilization of $\mathrm{Zn}, \mathrm{Cu}$ and $\mathrm{Cd}$. However, the $\mathrm{pH}$ elevation decreased the metal concentration either in solution or associated with the fraction readily available (exchangeable). On the other hand, the amount of metals found in the carbonate/surface oxide was increased with the use of amendments. In general, $\mathrm{CaCO}_{3}$ ( $\mathrm{pH}$ 7) decreased the biosolid dissolution and, consequently, the release of metals to solution. 


\section{INTRODUÇÃO}

Em sociedades industrializadas, grandes quantidades de resíduos são produzidas diariamente. Uma opção para disposição desse material é a aplicação agrícola. Desde 1970 vem aumentando o interesse no uso de resíduos provenientes de estação de tratamento de lodo de esgoto doméstico, também conhecido como biossólidos, como fonte de fertilizantes em áreas agrícolas e florestais (Tomlin et al., 1993). Aproximadamente metade da produção de biossólido nos Estados Unidos é atualmente aplicada ao solo. Na comunidade européia, mais de $30 \%$ do biossólido produzido é utilizado como fertilizante agrícola. A aplicação agrícola mostrou ser uma alternativa lógica e sensata para uso desse resíduo. $\mathrm{O}$ uso de biossólido pode melhorar alguns atributos do solo, tais como $\mathrm{o} p H$, conteúdos de matéria orgânica, nitrogênio e fósforo disponível (Tsadilas et al., 1995; López-Mosquera, 2000, Sastre et al., 2001). O biossólido é efetivo como fertilizante, resultando no aumento na produção de matéria seca de diversas culturas (Tsadilas et al., 1995). Pode também melhorar algumas características físicas do solo, tais como porosidade, estabilidade de agregados, densidade, retenção e movimento de água (Karapanagiotis et al., 1991). Entretanto, o uso de biossólido em áreas agrícolas e florestais pode ser limitado pelo conteúdo de metais presente nesse material.

Os metais pesados mais comumente encontrados no biossólido são chumbo $(\mathrm{Pb})$, níquel $(\mathrm{Ni})$, cádmio $(\mathrm{Cd})$, crômio $(\mathrm{Cr})$, cobre $(\mathrm{Cu})$ e zinco $(\mathrm{Zn})$. A concentração de metais depende da natureza e da intensidade da atividade industrial, além do tipo de processo empregado no tratamento do lodo de esgoto (Mattigod \& Page, 1983). Geralmente, resíduos de origem doméstica apresentam concentrações de metais inferiores às dos resíduos de origem industrial. $\mathrm{O}$ uso prolongado de biossólidos 
contendo metais pode levar ao acúmulo desses no solo (López-Mosquera et al., 2000), contaminar a cadeia alimentar e reduzir a produção de culturas agrícolas (Obrador et al., 1997). Uma vez que os metais pesados são persistentes no ambiente, eles irão permanecer na biosfera durante longo período de tempo. Além disso, os biossólidos podem introduzir ao solo níveis excessivos de certos nutrientes, sobretudo nitrogênio e fósforo, além de pesticidas e microrganismos patogênicos (Barry et al., 1995). A aplicação contínua de biossólido pode também aumentar a salinidade do solo e, conseqüentemente, elevar a disponibilidade de metais às plantas. Portanto, o risco de contaminação devido ao potencial movimento de metais pesados nos solos deve ser considerado quando o biossólido é aplicado, e o entendimento do comportamento desses metais no ambiente é fundamental para prever as possíveis consequiências dessa prática no agroecosistema.

Nos Estados Unidos, a aplicação de biossólido é controlada pela agência de proteção ambiental (United States Environmental Protection Agency- USEPA) através da norma EPA 503 (USEPA Clean Water Act 503 Regulations) (Estados Unidos, 1993). Essa norma, que regulamenta os limites para uso e disposição de biossólidos, controla a dose de aplicação, bem como a cultura que poderá ser cultivada posteriormente. Porém, quando comparados com padrões internacionais, os níveis de metais regulamentados pela EPA são extremamente permissivos (McBride, 1995; Schmidt, 1997). A acumulação máxima permitida para metais pesados $(\mathrm{Cd}, \mathrm{Cr}, \mathrm{Cu}, \mathrm{Mo}, \mathrm{Hg}, \mathrm{Ni}, \mathrm{Pb}$ e $\mathrm{Zn})$ e elementos não metálicos (As e Se) podem ser de 10-100 vezes superior aos níveis naturais encontrados na maioria dos solos (McBride, 1995). As premissas nas quais a EPA-503 foi desenvolvida são criticadas, sobretudo no que se relaciona aos resultados de análise de risco (McBride, 1995). Para aplicação no solo, foram considerados 14 destinos como possíveis rotas de transferência de poluentes do biossólido para as plantas, os animais e ao homem (Estados Unidos, 1994).

$\mathrm{Na}$ elaboração da norma 503, a EPA conduziu experimentos em casa-devegetação, com objetivo de determinar a absorção e fitotoxicidade dos poluentes presentes nos biossólidos. Nos vasos experimentais, os metais foram aplicados na forma de sais solúveis, e observou-se que o estudo conduzido nessas condições superestimou a fitotoxicidade e biodisponibilidade de metais (Estados Unidos, 1994). Isso foi devido à 
presença de determinados componentes nos biossólidos (óxidos e hidróxidos de Fe, matéria orgânica e fosfatos), que tem habilidade de reter os metais na matriz do biossólido, tornando-os menos disponíveis às plantas e ao homem (Estados Unidos, 1994). A EPA incluiu também na norma 503, biossólidos contendo baixos níveis de poluentes, os quais poderiam ser utilizados com regulamentação menos restritiva. Esses biossólidos foram caracterizados como "efeito adverso não observado" (no observed adverse effect level) ou NOAEL, e algumas restrições, tais como a quantidade máxima acumulada de poluentes, não foram obrigatórias para regulamentar uso desse tipo de biossólido.

Embora a EPA-503 considere a proteção com as plantas cultivadas, é praticamente impossível determinar os níveis de fitotoxicidade para todas as condições naturais, tais como espécie de planta, tipos de solo e condições ambientais (Schmidt, 1997). Fatores como sensibilidade interespécie, seleção dos níveis de fitotoxicidade e relação entre aplicação de elementos traços e taxa de absorção de planta podem afetar o comportamento das plantas em relação à presença de metais no solo (Schmidt, 1997). A EPA calculou a absorção de metais pela planta através do índice coeficiente de absorção (CA). No cálculo do CA foram analisados tecidos de plantas cultivadas em áreas tratadas com biossólidos. O CA baseou-se na concentração de metais em plantas cultivadas em um ou mais níveis de aplicação de biossólidos e comparou-se com plantas controle. Porém, McBride (1998) ressaltou que a concentração de metais em alguns casos foi excessivamente alta, sugerindo algum tipo de contaminação na amostra, como partículas de solo e deposição atmosférica ou técnicas analíticas inapropriadas. A falta de precisão torna esses resultados inapropriados para serem utilizados em análise de risco (McBride, 1998). Embora os sintomas fitotoxicidade ocorram apenas quando biossólidos com elevados níveis de metais são aplicados em altas doses, ou quando os solos exibam pH muito baixo (abaixo de 5) (Estados Unidos, 1994), a implicação a longo prazo dessa prática ainda é incerta.

A absorção de metais pela planta pode diferir, dependendo da fonte na qual o metal é adicionado. Quando sais contendo metais são adicionados ao solo, ocorre uma resposta linear na absorção pela planta, ou seja, com o aumento na concentração do metal no solo há correspondente aumento na concentração do mesmo na planta. Ao 
contrário, quando metais são aplicados ao solo via biossólido ocorre o fenômeno na absorção da planta denominado como efeito "platô". Esse "efeito platô" ocorre devido à presença de matéria adsorventes no próprio biossólido. Com a aplicação de doses iniciais de biossólido ocorre um aumento na absorção de metais pela planta e na adsorção dos mesmos pelo solo. À medida que maior quantidade de biossólido é incorporado ao solo, a reação de adsorção de metais na matriz do biossólido torna-se predominante em relação à adsorção pelo solo, resultando numa resposta linear na absorção de nutrientes pela planta, também conhecida como "efeito platô". A fração matéria orgânica presente no biossólido, por exemplo, promove a proteção do metal contra a decomposição e, conseqüentemente, reduz a absorção pela planta (McBride, 1995). A "teoria do platô" foi utilizada no desenvolvimento da EPA-503, considerando o efeito da matéria orgânica na restrição da disponibilidade às plantas dos metais pesados adicionados na forma de biossólido. Porém, são necessárias as seguintes condições com relação a "teoria do efeito platô": 1) até que o platô seja atingido, a aplicação contínua de biossólido irá resultar no aumento na concentração de metal no tecido vegetal. Se a aplicação é cessada, a concentração de metal na planta deve ser igual ao momento no qual foi interrompida; 2) Após o platô ser atingido, a aplicação contínua de biossólido não deve alterar a concentração de metal no tecido da planta, ou seja, a concentração deve ser igual à concentração quando o platô foi alcançado (Chang et al., 1997).

Os estudos sobre "efeito platô" rejeitam a hipótese conhecida como "teoria da bomba relógio". Nesse caso, considera-se que a mineralização da matéria orgânica do biossólido pode promover a liberação de metais em formas solúveis (McBride, 1995). O principal argumento da "teoria da bomba relógio" concentra-se nas conseqüências na concentração dos metais no solo e na planta, após o término da aplicação de biossólido. Experimentos de campo com dez anos de aplicação de biossólido mostraram que a concentração de Cd nos solos e no tecido da planta aumentou com o uso de biossólido e o "efeito platô" não foi atingido, mesmo quando as taxas de aplicação eram iguais a $1080 \mathrm{Mg} \mathrm{ha}^{-1}$ (Chang et al., 1997). Embora esses resultados não mostrem os "efeito platô", a concentração de metais na planta não aumentou após dez anos do término da aplicação do resíduo. Então, concluiu-se que tanto o "efeito platô" como a "teoria da bomba relógio" são hipóteses empíricas. 
Outro ponto a ser considerado é que muitos biossólidos utilizados pela EPA em experimentos no campo foram estabilizados com calcário, o que implica elevação do $\mathrm{pH}$ do material. Nesse caso, os metais tiveram sua disponibilidade limitada pelo $\mathrm{pH}$ do material, porém o $\mathrm{pH}$ do solo pode, gradualmente, diminuir após o término da aplicação de biossólidos (McBride, 1998). Portanto, se o solo for acidificado, a solubilidade e atividade dos metais em solos tratados com biossólidos podem aumentar (Chang et al., 1997).

É importante enfatizar que a EPA-503 foi baseada em experimentos de curtaduração e aplicação de doses relativamente baixas de metais no solo. Portanto, a questão “o que acontece com os metais tóxicos após o término da aplicação de biossólidos, em solos tratados durante longa duração?” ainda permanece (McBride, 1995). Não é claro se a disponibilidade de metais aumenta ou não com o tempo após o término da aplicação de biossólidos. Além disso, a contribuição de materiais orgânicos e inorgânicos capazes de reter metais no biossólido não é de fácil identificação. Sem uma conclusão se as teorias do "efeito platô" e da "bomba relógio" ocorrem realmente no solo, é difícil conhecer as implicações da aplicação de biossólidos nos solos (Chang et al., 1997). Outra crítica é que a EPA-503 não faz nenhuma consideração a respeito das diferenças químicas dos solos e dos biossólidos, assumindo que os constituintes inorgânicos irão permanentemente reter metais tóxicos em formas insolúveis (McBride, 1995). Porém, não se conhece a durabilidade e estabilidade cessas formas nos solos a longo prazo. A habilidade dos solos em remover elementos traços da solução do solo determina a fitodisponibilidade dos mesmos (Schmidt, 1997), e os fatores que afetam a solubilidade da matéria orgânica podem modificar a solubilidade e capacidade de lixiviação de metais nos solos. Os processos físicos no solo, tais como preparo e erosão, podem contribuir para perda de metais a longo prazo (McBride et al., 1997).

Nesse contexto, conclusões definitivas sobre os riscos e desvantagens do uso agrícola dos biossólidos são ainda questionáveis. Essa problemática ainda é mais acentuada em autros países que seguem a EPA-503, como o Brasil. Em solos altamente intemperizados, tais como os Latossolos do Brasil, com mineralogia predominantemente composta por óxidos de $\mathrm{Fe}$ e $\mathrm{Al}$, além de baixos valores de $\mathrm{pH}$, as reações de sorção do metal são particularmente diferentes, quando comparadas aos solos nos quais a EPA-503 
foi desenvolvida. Ainda, a dinâmica da matéria orgânica também é diferente nas regiões dos trópicos, quando comparada às condições de clima temperado. Portanto, as premissas assumidas na EPA-503 podem não ser aplicadas à essas condições específicas. A regulação para aplicação de biossólidos no solo deve considerar os fenômenos fisiológicos básicos do sistema biossólido-solo-planta e, sobretudo, deve ser desenvolvida para cada região e condição específica. Os solos servem como um meio através do qual águas subterrâneas são "repostas", e qualquer constituinte adicionado ao solo, tais como os metais pesados presentes nos biossólidos, pode afetar adversamente o uso dessas reservas, podendo trazer graves conseqüências à cadeia alimentar. 


\section{REVISÃO DE LITERATURA}

\subsection{Metais nos solos}

Os metais estão presentes no ambiente, e a maioria é essencial às plantas, aos animais e ao homem. Eles são constituintes naturais de rochas e sedimentos. Em condições naturais, a principal fonte de elementos nos solos é o material de origem no qual foram derivados. Fontes antropogênicas, incluindo emissões industriais, efluentes, biossólido, fertilizantes, condicionadores de solo e pesticidas, podem contribuir no aumento da concentração de metais nos solos. Na realidade, é impossível distinguir entre o aumento nos níveis de metais no solo devido a fontes naturais e/ou antropogênicas.

Os metais estão presentes na fase sólida e na solução do solo como íons-livres ou adsorvidos pelos colóides. A concentração de metais pesados no horizonte de superfície do solo é resultado da combinação do processo de formação de solo e atividades humanas e agrícolas. Doze metais são considerados essenciais para o homem: sódio $(\mathrm{Na})$, magnésio $(\mathrm{Mg})$, potássio $(\mathrm{K})$, cálcio $(\mathrm{Ca})$, crômio $(\mathrm{Cr})$, manganês $(\mathrm{Mn})$, ferro $(\mathrm{Fe})$, cobalto $(\mathrm{Co})$, cobre $(\mathrm{Cu})$, zinco $(\mathrm{Zn})$, selênio $(\mathrm{Se})$ e molibdênio $(\mathrm{Mo})$. Com relação aos elementos não-essenciais, mercúrio $(\mathrm{Hg})$, chumbo $(\mathrm{Pb})$, cádmio $(\mathrm{Cd})$ e arsênio $(\mathrm{As})$ são tóxicos ao ser humano e responsáveis pela maioria dos problemas de saúde devido à poluição do meio ambiente (Berglund et al., 1983).

A capacidade dos solos em reter e fornecer metais é um importante fator para prever o impacto ambiental do uso de resíduos. Metais podem ser aplicados ao solo na forma sólida, tal como os biossólidos, que entram em equilíbrio com a solução e, conseqüentemente, com a fase sólida do solo. Esse equilíbrio é controlado pelas 
propriedades químicas do solo e do resíduo (Figura 1). Em adição, a cinética de dissolução do metal irá determinar as taxas das reações.

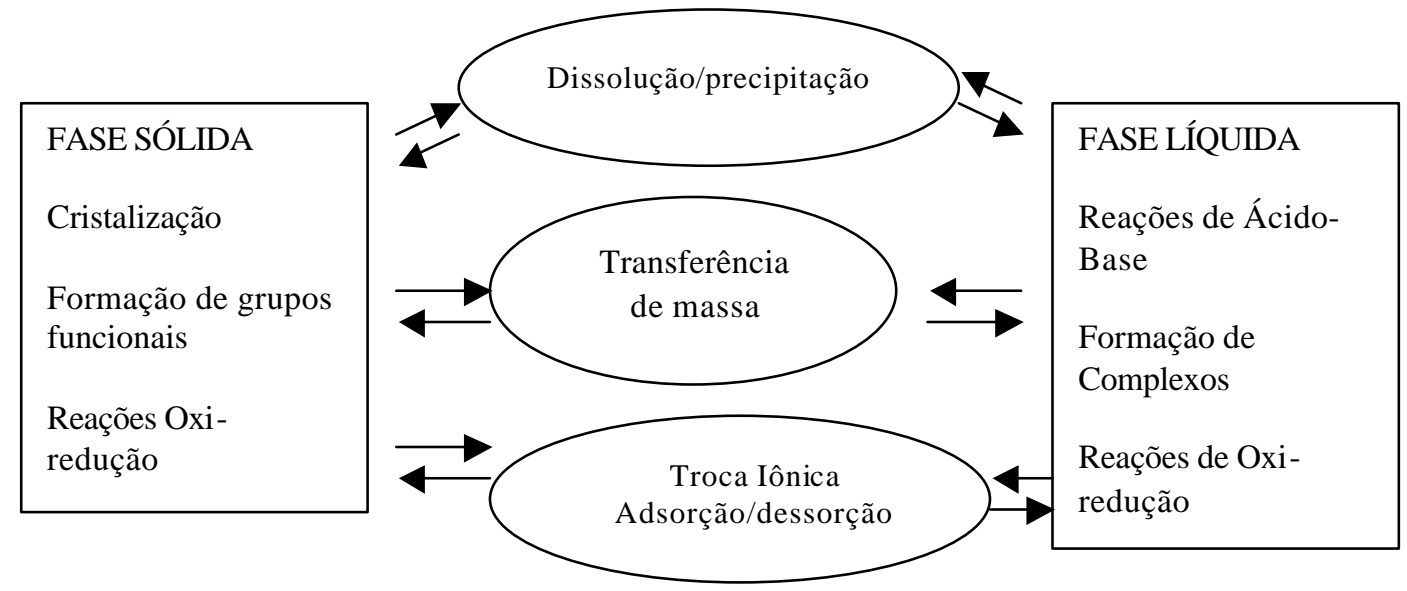

Figura 1 - Tipos de interação entre as fases sólida e líquida do solo (Adaptada de Mattigod \& Page, 1983).

Para avaliar o possível risco da aplicação de biossólidos em áreas agrícolas, é necessário conhecer a mobilidade e a biodisponibilidade de metais no solo. A solubilidade dos metais é controlada por reações de adsorção/dessorção, precipitação/dissolução e complexação. Essas interações influenciam a partição de metais nas fases líquida e sólida do solo e são responsáveis pela mobilidade e biodisponibilidade dos metais no sistema.

A quantidade total de metais no solo é distribuída em diferentes frações. Os metais podem estar presentes como íons-livres, como complexos organo-minerais solúveis ou adsorvidos às partículas do solo. O movimento de metais em solos tratados com biossólidos depende da composição desse resíduo, e as frações solúvel e trocável são as mais importantes em relação à poluição do lençol freático e à nutrição de plantas (Sastre et al., 2001). Biossólidos com elevada concentração de óxidos de ferro podem apresentar menores riscos de contaminação do meio ambiente por metais pesados, devido à capacidade de retenção de metais exibida por esses componentes. Por exemplo, a extração de metais em solos tratados com biossólidos pode ser reduzida com o tempo, 
devido, sobretudo, ao aumento no teor de matéria orgânica no solo (Karapanagiotis, 1991).

\subsection{Reações de adsorção}

Adsorção, definida como o acúmulo de uma substância ou material na interface entre uma superfície sólida e uma solução, parece ser o processo químico mais importante no controle da biodisponibilidade e do comportamento de metais em solos (Alloway, 1990; Sparks, 1995). A reação de adsorção é um importante fator que controla a atividade de metais pesados não apenas em solos, mas também em corpos de águas (McBride et al., 1997; Salam \& Helmke, 1998). Como resultado da adsorção, os metais são removidos da solução do solo e retidos na superfície dos colóides. Os grupos de superfície que complexam metais incluem o grupo hidrogênio, nas superfícies dos óxidos e dos minerais de argila, além dos grupos carboxílico e fenólico, na superfície da matéria orgânica do solo (Sposito, 1983).

Vários mecanismos estão envolvidos na adsorção de metais em solos, incluindo forças físicas (van der Waals e ligações eletrostáticas) e químicas (complexos de esfera interna) (Sparks, 1995). A natureza das interações e o mecanismo de adsorção podem ser diferentes, tais como (Filep, 1999):
a) van der Waals
b) Ligações de hidrogênio
c) Interação ion-dipolo
d) Forças eletrostáticas
e) Ligação covalente e outros tipos de ligações químicas

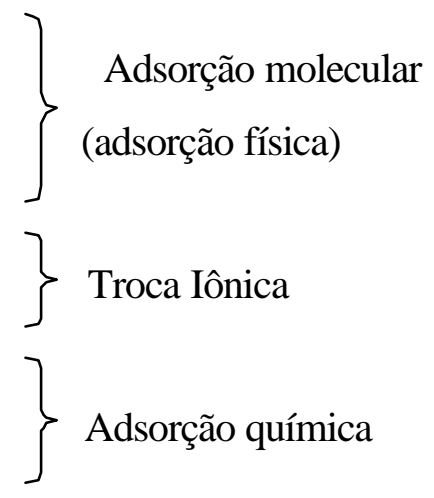

O tipo de interação que irá predominar depende de diversos fatores, dentre eles da quantidade e do tipo de sítios associados com a fase sólida do solo, da concentração do metal e dos ligantes capazes de formar complexos organo-minerais, do $\mathrm{pH}$, da 
condutividade elétrica e do potencial redox do solo (Kiekens, 1983). Entretanto, em geral, é difícil distinguir experimentalmente as forças envolvidas na reação de adsorção de metais.

A energia livre da reação de adsorção na superfície dos adsorventes pode ser descrita como (eq.1) (Ji \& Li, 1997):

$$
\Delta G_{\text {adorsorção }}=\Delta G_{\text {coulomb }}+\Delta G_{\text {quim.. }}+\Delta G_{\text {reação }}
$$

em que $\Delta G_{\text {coulomb }}=$ energia livre das interações eletrostáticas; $\Delta G_{\text {quim. }}=$ energia livre referente à adsorção química ou específica; $\Delta G_{\text {reação }}=$ relacionada ao tamanho e polaridade dos íons adsorvidos e da estrutura da solução adjacente à superfície adsorvente.

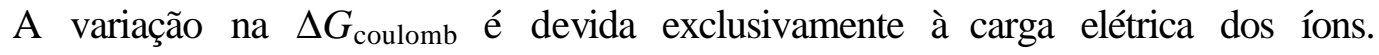
Quanto à $\Delta G_{\text {quim., }}$ as forças de ligação são determinadas pela natureza do adsorvente e pela espécie iônica. Se $\Delta G_{\text {quim }}$ é elevada, íons com mesma carga da superfície podem ser adsorvidos, uma vez que a energia dessa interação pode superar os mecanismos de repulsão eletrostática (Ji \& Li, 1997).

O valor da energia livre da reação de adsorção de metais pode servir como medida da extensão ou da força que guia esse equilíbrio e se a mesma é espontânea, num sistema fechado à temperatura e pressão constantes (Singh, 1971). Por exemplo, Silveira et al. (1999) observaram que a energia livre da adsorção de $\mathrm{Cu}$ em solos era espontânea e seu valor era maior nas menores concentrações do metal, sugerindo maior afinidade do $\mathrm{Cu}$ pelos sítios adsortivos nessas condições. À medida que as doses de $\mathrm{Cu}$ foram elevadas, a energia livre de adsorção do metal foi diminuída. 


\subsubsection{Adsorção não-específica}

Os íons em solução, tais como os metais pesados, estão em equilíbrio com os contra-íons que promovem o balanço de cargas na superfície dos colóides. De acordo com o princípio da eletroneutralidade, a adsorção não-específica de metais, também conhecida como adsorção eletrostática, deve ser seguida da dessorção de quantidades estequiométricas dos contra-1́ons (Harmsen \& Vlek, 1985; Ji \& Hi, 1997). Nesse tipo de adsorção, os metais são adsorvidos por forças eletrostáticas, resultando a formação de complexos de espera externa (Sparks, 1995). Considera-se que esse processo é reversível, controlado por difusão, estequiométrico e que exista alguma seletividade ou preferência dos íons pela superfície adsorvente, dependendo da sua valência e grau de hidratação. Tantos os colóides orgânicos como os inorgânicos estão envolvidos na adsorção não-específica.

Dentre outros fatores, a superfície de cargas, o pH, a concentração de íons e os ânions acompanhantes podem afetar a adsorção não-específica. Para cátions metálicos a adsorção depende da densidade de cargas negativas na superfície dos colóides e não, necessariamente, do balanço de cargas do solo (Ji \& Li, 1997). Por exemplo, Latossolos que apresentam balanço positivo de cargas nos horizontes B são capazes de adsorver metais quando o pH se encontra abaixo do seu ponto de carga zero. Silveira et al. (2002) observaram que horizontes de subsuperfície, que exibiam balanço positivo de cargas, eram capazes de adsorver ao redor de 65-67\% da dose de $\mathrm{Cu}$ adicionada, e que essa reação era favorecida com a eliminação dos óxidos de Fe. Esses autores sugeriram que a eliminação dos óxidos de Fe das amostras reduziu a quantidade de cargas positivas na superfície dos colóides e, conseqüentemente, diminuiu as forças de repulsão entre o metal e a superfície favorecendo a adsorção de $\mathrm{Cu}$. $\mathrm{O} \mathrm{pH}$ do solo pode afetar a espécie química do metal em solução e, em adição, alterar a quantidade de cargas na superfície de solos com carga variável. O efeito do ânion acompanhante em solução é mais evidente, novamente, em solos com cargas variáveis, uma vez que os ânions podem alterar a força iônica e as propriedades da superfície de cargas, ou ainda, podem formar pares-iônicos com os metais. 
A afinidade dos colóides de superfície em adsorver cátions aumenta com a valência dos mesmos. Para cátions com diferentes valências, a afinidade, em geral, segue a ordem $\mathrm{M}^{+}<\mathrm{M}^{2+}<\mathrm{M}^{3+}$. Para cátions de mesma valência, a afinidade na adsorção é determinada, principalmente, pelo raio iônico hidratado (Ji \& Li, 1997).

Apesar de a contribuição da adsorção não-específica na retenção de metais no solo ser relativamente inferior à adsorção específica, esse tipo de interação é importante no suprimento de nutrientes no solo e, consequientemente, às plantas.

\subsubsection{Adsorção específica}

A adsorção de metais não pode ser explicada simplesmente devido às forças eletrostáticas, especialmente em solos nos quais os óxidos apresentam importante função. O ponto de carga zero da maioria de óxidos é superior a 8, porém a adsorção de íons metálicos de transição ocorre, em geral, em valores de pH entre 3-7 (Yu et al., 1997). Nesse caso, a superfície apresenta balanço positivo de cargas, o que ocasiona em forças de repulsão entre a superfície do colóide e os metais. Os metais então se combinam com os grupos hidrogênio e oxigênio na superfície dos óxidos, resultando a formação de complexos de superfície.

A adsorção específica, ou adsorção química, de metais no solo resulta da formação de moléculas estáveis, com elevada energia de ligação, e tem como conseqüência à formação dos chamados complexos de esfera interna (Sparks, 1995). Nesse tipo de ligação, estão envolvidas forças específicas, e a adsorção depende da natureza dos cátions e das propriedades da superfície do colóide. Esse mecanismo é, muitas vezes, irreversível, mais lento do que a formação de complexos de esfera externa e é pouco afetado pela força iônica da solução (Sparks, 1995). Com o tempo, a tendência

é que metais adsorvidos especificamente na superfície dos colóides difundam para o interior das partículas, dificultando posterior dessorção (Barrow, 1985).

Os óxidos de $\mathrm{Al}, \mathrm{Fe}$ e $\mathrm{Mn}$ e a matéria orgânica são os principais constituintes do solo envolvidos nesse tipo de adsorção. Os minerais silicatados podem ter a habilidade 
de adsorver especificamente metais pesados, demonstrando que podem apresentar propriedades similares às dos grupos hidroxílicos das superfícies dos óxidos.

Dentre as espécies de cátions que podem ser adsorvidas especificamente, a maioria é metal pesado, tal como $\mathrm{Cu}, \mathrm{Zn}$, $\mathrm{Co}$ e $\mathrm{Cd}$. A adsorção específica ocorre porque os metais pesados e os íons metálicos dos grupos IB e IIB apresentam elevada quantidade de cargas elétricas no seu núcleo atômico, pequeno tamanho iônico e elevada polaridade (Yu et al., 1997). Além disso, os metais pesados apresentam maior habilidade em se deformar quando comparado aos metais alcalinos e alcalinos terrosos. Finalmente, os metais pesados existem na forma de cátions hidratados, tal como $\mathrm{MOH}^{+}$, o que contribui para a redução na quantidade média de carga elétrica por íon e, consequentemente, na redução na "barreira" que deve ser sobreposta quando os íons se aproximam da superfície dos óxidos, facilitando então a interação entre os íons e a superfície dos colóides (Yu et al., 1997).

$\mathrm{Na}$ adsorção específica não ocorre a dessorção de contra-íons e as propriedades da superfície de cargas dos óxidos podem ser modificadas (eq. 2)

$$
\begin{aligned}
& -\mathrm{Fe}-\mathrm{OH}+\mathrm{M}\left(\mathrm{H}_{2} \mathrm{O}\right)_{6}{ }^{2+} \rightarrow-\mathrm{Fe}-\mathrm{OM}\left(\mathrm{H}_{2} \mathrm{O}\right)_{5}{ }^{+} \\
& \mathrm{M}=\text { metal. }
\end{aligned}
$$

A adsorção específica de metais pesados não atua nas reações de trocas de cátions, mas é um importante fator no controle da concentração, biodisponibilidade e toxicidade de metais nos solos.

\subsection{Fatores que afetam a adsorção de metais}

Solos minerais e orgânicos podem adsorver metais em diferentes intensidades. A matéria orgânica, os óxi-hidróxidos de $\mathrm{Fe}$ e $\mathrm{Al}$ e os minerais de argila são os principais componentes dos solos que influenciam as reações de sorção (Barry et al., 1995). Mesmo se esses componentes não estejam presentes em elevadas concentrações nos solos, eles podem estar dispersos nas superfícies de areias e minerais de argila, 
influenciando consideravelmente as reações de adsorção. Em solos que receberam altas doses de metais, o complexo formado entre metal-colóide pode estar distribuído ao acaso na superfície das partículas ou estar concentrado em agregados (Martinéz \& McBride, 1998). Metais tais como $\mathrm{Cd}^{+2}, \mathrm{Cu}^{+2}, \mathrm{~Pb}^{+2}$ e $\mathrm{Zn}^{+2}$, em condições experimentais específicas, podem ser oclusos nas estruturas dos óxidos de Fe, quer seja pela formação de agregados com os óxidos, quer seja pela segregação no interior ou na superfície do óxido (Martinéz \& McBride, 1998). Além desses fatores, o pH, a capacidade de troca catiônica (CTC) e o potencial redox podem controlar a mobilidade de metais no solo (Lombi \& Gerzabek, 1998).

Por exemplo, o $\mathrm{pH}$ do solo é um importante fator para maioria dos metais pesados, uma vez que a disponibilidade dos mesmos é relativamente baixa em valores de pH ao redor de 6,5 a 7 (Kabata-Pendias \& Pendias, 1987). Com exceção do Mo, Se e As, a mobilidade de elementos traços é reduzida com o aumento do $\mathrm{pH}$, devido à precipitação de formas insolúveis como hidróxidos, carbonatos e complexos orgânicos.

A CTC está relacionada com a capacidade do solo em adsorver metais. Quanto maior a CTC, mais sítios de adsorção estarão disponíveis nos colóides do solo para adsorver metais. Assim, amostras de superfície e subsuperfície de um mesmo solo podem exibir diferentes capacidades em adsorver metais, uma vez que esse comportamento está relacionado com as propriedades dos solos e do elemento específico (Barry et al., 1995). Porém, a CTC do solo é influenciada pelo pH da solução. Com o aumento do $\mathrm{pH}$, a superfície de cargas negativas é aumentada, favorecendo a atração eletrostática entre o sorvente e o metal (Sposito, 1989). A menos que existam ligantes na solução capazes de competir com o metal pela superfície dos grupos funcionais, o aumento no $\mathrm{pH}$ resulta em maior quantidade de metal adsorvido. No caso do $\mathrm{Cu}$, por exemplo, esse metal tem a adsorção descrita por uma curva do tipo $\mathrm{H}$ (elevado coeficiente angular no início da isoterma, denotando alta afinidade do solo pelo adsorvato) (Silveira et al., 2002). Esses autores sugeriram a possível formação de complexos de esfera interna entre o $\mathrm{Cu}$ e a superfície adsorvente. Porém, se ligantes orgânicos estão presentes na solução, a adsorção torna-se menos acentuada, resultando numa curva do tipo $\mathrm{S}$ (baixo coeficiente angular no início da isoterma que tende a 
aumentar com a concentração do adsorvato, sugerindo que baixa afinidade das partículas de solo pelo adsorvato) (Sposito, 1989).

A presença de alguns cátions pode afetar a adsorção de metais nos solos. Por exemplo, $\mathrm{Ca}^{2+}$ compete efetivamente com metais pesados por sítios de adsorção, e essa competição parece ser maior para $\mathrm{Zn}$ e $\mathrm{Cd}$, do que para $\mathrm{Cu}$ e $\mathrm{Pb}$ (Kiekens, 1983). Segundo esse autor, esse fenômeno ocorre porque o $\mathrm{Zn}$ e o $\mathrm{Cd}$ são retidos nos solos por forças eletrostáticas, enquanto o $\mathrm{Cu}$ e o $\mathrm{Pb}$ são capazes de formar complexos com a matéria orgânica e com óxidos de $\mathrm{Fe}, \mathrm{Al}$ e $\mathrm{Mn}$. Em soluções diluídas, a adsorção de íons de maior valência é favorecida em relação aos íons de menor valência. Isso ocorre porque em altas concentrações, a atividade de cátions polivalentes e a quantidade de íons- livres diminuem mais rapidamente do que cátions monovalentes (Filep, 1999). A presença de ligantes orgânicos e inorgânicos na solução do solo pode afetar a adsorção de elementos traços. Esse efeito pode ser classificado em quatro categorias gerais (Sposito, 1983):

(i) O ligante tem alta afinidade pelo metal e ambos formam um complexo solúvel com alta afinidade pelo adsorvente,

(ii) $\quad \mathrm{O}$ ligante tem alta afinidade pelo adsorvente, é adsorvido, e o complexo ligante-adsorvente tem alta afinidade pelo metal,

(iii) $\mathrm{O}$ ligante tem alta afinidade pelo metal e ambos formam um complexo solúvel com baixa afinidade pelo adsorvente,

(iv) $\mathrm{O}$ ligante tem alta afinidade pelo adsorvente, é adsorvido, e o complexo ligante-adsorvente tem baixa afinidade pelo metal.

O potencial redox do solo pode influenciar a solubilidade de metais pesados. Quando reações de oxidação estão envolvidas, a solubilidade de metais aumenta com a redução do $\mathrm{pH}$. Porém, em condições de redução, a solubilidade de $\mathrm{Zn}, \mathrm{Cu}, \mathrm{Cd}$ e $\mathrm{Pb}$ é maior em valores de $\mathrm{pH}$ mais altos, na faixa alcalina, devido à formação de complexos organo-minerais estáveis. Por outro lado, na faixa de $\mathrm{pH}$ entre 4-6, a solubilidade dos metais pesados é menor devido à formação de complexos organo-minerais insolúveis e/ou complexos com sulfetos (Kiekens, 1983). 


\subsection{1 Óxidos de ferro e manganês}

Dentre os diversos tipos de óxidos e hidróxidos presentes no solo, tais como os óxidos de silício, titânio, alumínio, os óxidos de $\mathrm{Fe}$ e $\mathrm{Mn}$ têm maior influência no comportamento de elementos traços nos solos (Kabata-Pendias \& Pendias, 1984). Eles estão presentes nos solos em diversos tipos de minerais e com diferentes graus de cristalinidade, ou ainda, podem estar recobrindo partículas de solo e/ou formando concreções ou nódulos.

Os óxidos de $\mathrm{Fe}$ e Mn apresentam elevada capacidade adsortiva de elementos traços e regulam a mobilidade e o transporte de íons em diversos compartimentos do ecossistema (biota, solo, rios, lagos e oceanos) (Benjamin \& Leckie, 1981; Cornell \& Schwetmann, 1996). Alguns metais pesados, tais como o $\mathrm{Cd}, \mathrm{Cu}$ e $\mathrm{Zn}$, podem estar presentes como constituintes da estrutura dos óxidos nos solos (Kabata-Pendias \& Pendias, 1984; Singh \& Gilkes, 1992).

Os óxidos apresentam grupos funcionais hidroxílicos na superfície, altamente reativos (Sposito, 1989). A interação entre os metais e os grupos funcionais de superfície pode se dar por meio da formação de complexos de esfera externa ou complexos de esfera interna. No primeiro caso, há presença de pelo menos uma molécula de água entre o íon e o grupo funcional e, em geral, estão envolvidos mecanismos de ligação eletrostática, enquanto no segundo o íon e a superfície ligam-se diretamente por meio de ligações covalentes, o que thes garante maior estabilidade em relação aos complexos de esfera externa (Sposito, 1989). Os óxidos de Fe e Mn apresentam sítios de adsorção com diferentes afinidades em reter metais (Benjamin \& Leckie, 1981).

Os óxidos de Fe mais comuns que ocorrem nos solo são a goethita $(\alpha-\mathrm{FeOOH})$ e a hematita $\left(\alpha-\mathrm{Fe}_{2} \mathrm{O}_{3}\right)$. Podem ainda estar presentes no solo, em menor abundância, a lepidocrocita, a ferrihidrita e a maghemite (Schwertmann, 1991). A solubilidade dos óxidos de $\mathrm{Fe}$ é extremamente baixa na faixa de $\mathrm{pH}$ mais comum nos solos e, em geral, fatores como o tamanho das partículas, o grau de cristalinidade e a substituição de $\mathrm{Fe}$ por Al influenciam essa característica (Schwertmann, 1991). 
Os óxidos de Fe são constituintes importantes em solos altamente intemperizados da região tropical e subtropical que contém caulinita como principal mineral de argila (Singh \& Gilkes, 1992). Eles desempenham papel essencial nas características químicas e físicas desses solos. Tanto as formas cristalinas como as mal-cristalizadas são capazes de reter metais pesados. Em geral, os óxidos de Fe mal-cristalizados correspondem à forma mais ativa do ponto de vista químico (Chao \& Zhou, 1983). Benjamin \& Leckie (1981), estudando a adsorção de $\mathrm{Cd}, \mathrm{Cu}, \mathrm{Pb}$ e $\mathrm{Zn}$ em óxidos de $\mathrm{Fe}$ amorfos sintetizados no laboratório, encontraram que a adsorção desses metais era inicialmente rápida (uma hora), seguida de uma segunda fase lenta, sugerindo a existência de diferentes mecanismos de adsorção. Mattigod et al. (1981) consideram que a adsorção de metais nos óxidos é um processo que ocorre em dois estágios. O primeiro estágio, mais rápido, corresponde à adsorção nos sítios altamente acessíveis na superfície do colóide, seguido por um segundo estágio, mais lento, caracterizado pela modificação das características da superfície, co-precipitação associada aos óxidos de Fe e Mn e difusão na fase sólida. Esse segundo estágio pode perdurar por dias (Ross, 1994). Cornell \& Schwertmann (1996) encontraram que a cinética de adsorção de cátions pelos óxidos de Fe foi rápida, especialmente se está envolvida a formação de complexos de esfera externa. Esses autores ressaltam a existência de dois tipos de sítios de adsorção de metais nos óxidos de Fe, um com baixa e outro com alta energia de ligação.

Os óxidos de $\mathrm{Mn}$ nos solos são quase invariavelmente contaminados com sesquióxidos, silicatos, outros constituintes e alguns metais como o $\mathrm{Co}, \mathrm{Cu}, \mathrm{Ni}, \mathrm{Zn}, \mathrm{Pb}$, Cr e V (Gilkes \& McKenzie, 1988). Embora vários minerais contenham o elemento como constituinte essencial, esses minerais têm sua ocorrência limitada, e a maior parte do Mn presente no solo ocorre como substituição de outros elementos (Gilkes \& McKenzie, 1988). Em geral, o Mn encontra-se associado com silicatos ferromagnesianos e outros minerais contendo Fe. Dentre os óxidos de Mn mais comuns, se destacam a birnessita $\left(\left(\mathrm{Na}_{0,7}, \mathrm{Ca}_{0,3}\right) \mathrm{Mn}_{7} \mathrm{O}_{014} 2.8 \mathrm{H}_{2} 0\right)$ e a vernadita $\left(\mathrm{MnO}_{2}(?)\right)$.

Os óxidos de Mn podem participar de diversas reações no solo, incluindo as reações de troca iônica e adsorção específica (Norvell, 1988). Diversos metais pesados podem ser encontrados em concentrações relativamente elevadas em concreções e 
nódulos ricos em Mn (Norvell, 1988). Devido ao do PCZ (ponto de carga zero) dos óxidos de Mn variar de 1,5 a 4,6, em geral, na faixa de $\mathrm{pH}$ do solo ao redor de 5, esses minerais desenvolvem superfície de cargas negativas e podem adsorver cátions (Gilkes, McKenzie, 1988). A adsorção de metais pelos óxidos de Mn pode ocorrer numa extensa faixa de pH. Assim como os óxidos de Fe, a solubilidade dos óxidos de Mn depende do $\mathrm{pH}$ e do pe do meio. Em geral, com a diminuição do $\mathrm{pH}$ e do pe, a solubilidade dos óxidos de Mn é aumentada, porém essa tendência pode ser mais acentuada dependendo do tipo de mineral (Norvell, 1988).

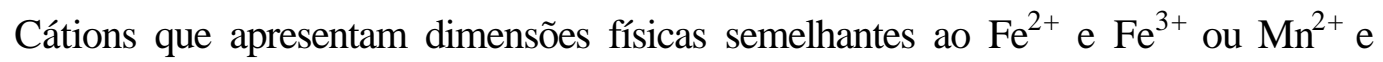

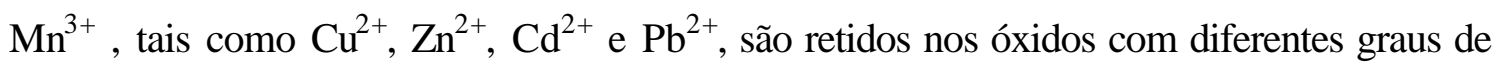
afinidade (Kabata-Pendias \& Pendias, 1984). Existe uma correlação entre a afinidade dos óxidos de Fe em reter os metais e a primeira constante de hidrólise do metal em solução (Cornell \& Schwertmann, 1996). O aumento na habilidade do metal em formar complexos favorece os mecanismos de adsorção específica (Ross, 1994). Para Sposito (1989), a afinidade de um componente do solo em adsorver um íon-livre é favorecida com o aumento na tendência do cátion em formar complexos de esfera interna com o adsorvente. A adsorção específica de metais pesados nos óxidos de Mn segue a ordem: $\mathrm{Pb}>\mathrm{Cu}>\mathrm{Mn}>\mathrm{Co}>\mathrm{Zn}>\mathrm{Ni}$ (Gilkes \& McKenzie, 1988). Cornell \& Schwertmann (1996) sugeriram que a afinidade da goethita em reter metais pode ser descrita como: $\mathrm{Cu}>\mathrm{Pb}>$ $\mathrm{Zn}>\mathrm{Cd}>\mathrm{Co}>\mathrm{Ni}>\mathrm{Mn}$. Para a hematita, segue-se a mesma sequiência, porém o $\mathrm{Pb}$ apresenta como o metal adsorvido com maior intensidade, seguido do $\mathrm{Cu}$. $\mathrm{O} \mathrm{Pb}$, o $\mathrm{Cu}$ e o Zn são adsorvidos preferencialmente em óxidos e frações orgânicas do solo em relação a Cd, Ni e Co (Ross, 1994). Benjamin \& Leckie (1981) encontraram que a adsorção era diferenciada dependendo do metal em questão. Para esses autores, embora os metais sejam adsorvidos com diferentes graus de afinidade, pode ocorrer a competição desses pelos sítios de adsorção dos óxidos, sobretudo quando todos os cátions se encontram em baixas concentrações. 


\subsubsection{Matéria orgânica}

A matéria orgânica do solo é um fator importante na retenção de metais. Associações organo-metálicas podem ocorrer tanto na fase sólida, como na fase líquida do solo e/ou de resíduos, tais como no biossólido.

Alguns metais, tais como o cobre, podem ser complexados pelo carbono orgânico dissolvido (COD), aumentando os riscos de lixiviação do metal no perfil (Moolenaar \& Beltrami, 1998). Húmus e outros compostos orgânicos podem quelatar os metais e formar moléculas estáveis. As frações húmicas com baixo peso molecular são mais efetivas na complexação de íons metálicos, uma vez que esses compostos contêm elevadas concentrações de grupos fenólico (Ph-OH) e carboxílico (-COOH).

As substâncias húmicas são separadas de acordo com a solubilidade. Os ácidos húmicos (HA) são solúveis apenas em meio alcalino, enquanto os ácidos fúlvicos (FA) são solúveis em meios alcalino e ácido. Ambos, HA e FA apresentam diferentes funções no controle da absorção de metais pelas plantas. Geralmente, os complexos FA-metal são solúveis, enquanto os HA-metal são insolúveis (McBride, 1995). Dependendo da solubilidade, o complexo metal-matéria orgânica pode ser encontrado na fase líquida ou na fase sólida. Complexos solúveis, em geral, envolvem os FA, os quais ligam-se com os metais em uma larga faixa de $\mathrm{pH}$. Na forma de complexos solúveis os metais são disponíveis às plantas, enquanto nos complexos insolúveis os metais são imobilizados. Com o tempo, a tendência é que os níveis de material orgânica solúvel e a decomposição

de compostos orgânicos diminuam, e os conteúdos totais de metais estalibizem em concentrações baixas, reduzindo a biodisponibilidade dos mesmos (McBride, 1995), ao mesmo tempo em que, paralelamente, ocorre a transformação na solução do solo de complexos solúveis em insolúveis (Schmidt, 1997).

A estabilidade de complexos orgânicos é fortemente influenciada pela variação no $\mathrm{pH}$. Em geral, em baixos valores de $\mathrm{pH}$, a maioria dos metais encontra-se na forma iônica, porém com o aumento no $\mathrm{pH}$ há a tendência de se formarem complexos com HA. Para os FA, a estabilidade dos complexos aumenta na faixa de $\mathrm{pH}$ entre 3,5-5,0 (Kiekens, 1983). Porém, a estabilidade dos complexos FA-metal pode diminuir com o 
aumento na força iônica da solução. Embora seja difícil calcular a constante de estabilidade dos HA e FA complexos, algumas sugestões têm sido desenvolvidas (Tabela 1).

Tabela 1. Ordem de estabilidade dos complexos em diferentes pHs. (Adaptada de Filep, 1999)

\begin{tabular}{lll}
\hline Fração & $\mathrm{pH}$ & Seqüência de estabilidade \\
\hline Ácido Fúlvico & 3 & $\mathrm{Fe}^{3+}>\mathrm{Al}^{3+}>\mathrm{Cu}^{2+}>\mathrm{Ca}^{2+}>\mathrm{Zn}^{2+}>\mathrm{Mn}^{2+}>\mathrm{Mg}^{2+}$ \\
5 & $\mathrm{Cu}^{2+} \approx \mathrm{Ca}^{2+}>\mathrm{Mn}^{2+}>\mathrm{Zn}^{2+}>\mathrm{Mg}^{2+}$ \\
7 & $\mathrm{Cu}^{2+}>\mathrm{Ca}^{2+} \approx \mathrm{Zn}^{2+}>\mathrm{Nn}^{2+}$ \\
8 & $\mathrm{Cu}^{2+}>\mathrm{Ca}^{2+}>\mathrm{Zn}^{2+}>\mathrm{Nn}^{2+}$ \\
Ácido Húmico & & \\
& 7 & $\mathrm{Al}^{3+}>\mathrm{Cu}^{2+}>\mathrm{Ca}^{2+}>\mathrm{Mn}^{2+}>\mathrm{Zn}^{2+}$ \\
& 8 & $\mathrm{Cu}^{2+}>\mathrm{Zn}^{2+} \approx \mathrm{Mn}^{2+}>\mathrm{Ca}^{2+}$ \\
\hline
\end{tabular}

A influência do $\mathrm{pH}$ nas substâncias húmicas ocorre porque a maioria dos grupos funcionais, tais como os grupos carboxílicos, fenólico e amino, é pH-dependente. Se o pH da solução muda, ocorre protonação ou desprotonação da superfície de cargas. Para o grupo carboxílico, o pK é ao redor de 3-5, enquanto para o fenólico encontra-se entre 910 (Filep, 1999). Por esse motivo, a capacidade de ionização é maior para o grupo carboxílico nos valores comumente encontrados nos solos.

A material orgânica pode formar complexos organo-minerais com minerais de argila do tipo 2:1 ou com óxidos de Fe e Al. Esses complexos apresentam forte ligação por coordenação, alterando as características dos colóides. A interação entre hidróxidos e óxidos e a material orgânica também ocorre quando a superfície do mineral é recoberta por um filme de hidróxidos de Fe e Al (Filep, 1999). 


\subsection{Equilíbrio entre as fases sólida e líquida}

O conteúdo total de metais pesados em solos tratados com biossólidos pode não refletir diretamente a disponibilidade dos mesmos às plantas. Elevadas concentrações de metais no solo nem sempre refletem altos teores nas plantas. Para alguns autores, a concentração total de metais é o índice mais útil para calcular o grau de acumulação de metais nos solos, porém a biodisponibilidade dos mesmos é mais bem representada pela composição da solução do solo (Mattigod \& Page, 1983). Lópes-Mosquera et al. (2000) não encontraram correlação significativa entre a concentração total de metais no solo e na planta. Embora a solubilidade dos metais seja, inicialmente, reduzida pelas reações de sorção, a longo prazo a solubilidade é controlada pelas formas químicas presentes, as quais também podem variar com o tempo (Martinéz and McBride, 1998). O conhecimento da distribuição de metais e a especiação são essenciais para o entendimento da interação química solo-metal (Mattigod \& Page, 1983).

No sistema solo, a maioria dos íons pode estar presente na forma livre ou interagir com outros íons ou moléculas, formando pares iônicos. A solução do solo pode conter de 100 a 200 complexos solúveis diferentes (Sposito, 1994). Geralmente, os cátions metálicos livres e os complexos com sulfatos são mais importantes em solos ácidos, enquanto os complexos com carbonato e borato destacam-se solos alcalinos (Tabela 2).

Em solos tratados com biossólidos, a distribuição de metais depende de uma série de características dos solos e do resíduo, sendo que o $\mathrm{pH}$ é, provavelmente, o fator mais importante (Obrador, 1997). Em baixos valores de pH, as formas "livres" dos metais são favorecidas, enquanto em pHs elevados, há a formação de complexos com hidroxilas e carbonatos (Sposito, 1994).

Ligações eletrostáticas e covalentes estão envolvidas na formação do par iônico. Para formar-se um par iônico, os íons com cargas opostas devem aproximar-se a uma distância mais próxima do que a distância média em condições normais. Essa distância 
Tabela 2 . Principais espécies químicas de elementos traços em soluções de solos ácido e alcalino (condições aeróbicas). (Adaptada de Sposito, 1983).

\begin{tabular}{|c|c|c|}
\hline & \multicolumn{2}{|c|}{ Principais Espécies } \\
\hline Metal & Solos Ácidos & Solos Alcalinos \\
\hline \multirow[t]{2}{*}{$\operatorname{Mn}(\mathrm{II})$} & $\mathrm{Mn}^{2+}, \mathrm{MnSO}_{4}{ }^{0}, \mathrm{Org}$ & $\mathrm{Mn}^{2+}, \quad \mathrm{MnSO}_{4}{ }^{0}, \quad \mathrm{MnCO}_{3}{ }^{0}$, \\
\hline & & $\mathrm{MnHCO}_{3}{ }^{+}, \mathrm{MnB}(\mathrm{OH})_{4}^{+}$ \\
\hline $\mathrm{Fe}(\mathrm{II})$ & $\mathrm{Fe}^{2+}, \mathrm{FeSO}_{4}{ }^{0}, \mathrm{FeHP}_{2} \mathrm{O}_{4}^{+}$ & $\mathrm{Fe}^{2+}, \mathrm{FeCO}_{3}{ }^{0}, \mathrm{FeHCO}_{3}{ }^{+}, \mathrm{FeSO}_{4}{ }^{0}$ \\
\hline \multirow[t]{2}{*}{$\mathrm{Ni}(\mathrm{II})$} & $\mathrm{Ni}^{2+}, \mathrm{NiSO}_{4}{ }^{0}, \mathrm{NiHCO}_{3}^{+}$, Org & $\mathrm{NiCO}_{3}{ }^{0}, \quad \mathrm{NiHCO}_{3}{ }^{+}$ \\
\hline & & $\mathrm{MnB}(\mathrm{OH})_{4}^{+}$ \\
\hline \multirow[t]{2}{*}{$\mathrm{Cu}(\mathrm{II})$} & Org, $\mathrm{Ni}^{2+}$ & $\mathrm{CuCO}_{3}{ }^{0}, \quad$ Org \\
\hline & & $\mathrm{Cu}\left(\mathrm{B}(\mathrm{OH})_{4}\right)_{2}{ }^{0}$ \\
\hline \multirow[t]{2}{*}{$\mathrm{Zn}(\mathrm{II})$} & $\mathrm{Zn}^{2+}, \mathrm{ZnSO}_{4}{ }^{0}$ & $\mathrm{ZnHCO}_{3}{ }^{+}, \mathrm{ZnCO}_{3}{ }^{0}, \mathrm{Zn}^{2+}, \mathrm{ZnSO}_{4}{ }^{0}$, \\
\hline & & $\mathrm{ZnB}(\mathrm{OH})_{4}^{+}$ \\
\hline $\mathrm{Cd}(\mathrm{II})$ & $\mathrm{Cd}^{2+}, \mathrm{CdSO}_{4}{ }^{0}, \mathrm{CdCl}^{+}$ & $\mathrm{Cd}^{2+}, \mathrm{CdCl}^{+}, \mathrm{CdSO}_{4}{ }^{0}, \mathrm{CdHCO}_{3}{ }^{+}$ \\
\hline \multirow[t]{2}{*}{$\mathrm{Pb}(\mathrm{II})$} & $\mathrm{Pb}^{2+}, \mathrm{Org}, \mathrm{PbSO}_{4}{ }^{0}, \mathrm{PbHCO}_{3}{ }^{+}$ & $\mathrm{PbCO}_{3}{ }^{0}, \quad \mathrm{PbHCO}_{3}{ }^{+}, \mathrm{Pb}\left(\mathrm{CO}_{3}\right)_{2}{ }^{2-}$, \\
\hline & & $\mathrm{PbOH}^{+}$ \\
\hline
\end{tabular}

mínima necessária para formação do par ồnico $\left(r_{\text {min }}\right)$ pode ser calculada de acordo com eq. 3 (N. Bjerrum, citado por Filep, 1999)

$$
\mathrm{r}_{\min }=\frac{\left(\mathrm{Z}_{\mathrm{i}} \underline{\mathrm{Z}}_{\mathrm{i}}\right) \mathrm{e}^{2}}{8 \pi \varepsilon \mathrm{kT}}
$$

na qual $Z_{j}$ é a carga de um dado íon j; $Z_{i}$ é a carga do íon i adjacente ao íon j; e é a unidade de carga elétrica; $\varepsilon$ é a permissividade do meio; k é a constante de Boltzmann e T é a temperatura termodinâmica.

Uma vez que a distância mínima é alcançada, forma-se o par iônico em solução. Por exemplo, em soluções com íons do tipo $1: 1$, a $25^{\circ} \mathrm{C}$, à distância para que haja a formação de um par iônico é $0,357 \mathrm{~nm}$, enquanto em soluções do tipo 2:2 é, 
aproximadamente, 1,4 nm (Filep, 1999). A força iônica da solução afeta o tipo dos pares iônicos formados. Em soluções concentradas, com eletrólitos fortes, os íons podem formar pares iônicos mais facilmente do que em soluções diluídas

Carbonatos, fosfatos, molibdatos, $\mathrm{OH}^{-}$e outros vários compostos orgânicos, incluindo humatos e fulvatos podem precipitar com metais. A precipitação de "íonslivres" $\left(\mathrm{M}^{\mathrm{n}+}\right)$ na solução do solo depende do produto de solubilidade (eq. 4).

$$
\begin{aligned}
& \mathrm{Ks}=(\mathrm{M})^{\mathrm{n}}(\mathrm{R})^{\mathrm{m}} \\
& -\log \left(\mathrm{M}^{\mathrm{n}+}\right)=\mathrm{pM}=\underline{\mathrm{pKs}-\mathrm{m} . \mathrm{pR}}
\end{aligned}
$$

$\mathrm{n}$

Baseado no produto de solubilidade, Lindsay (1979) descreveu equações teóricas para metais:

$$
\begin{aligned}
& \log \left(\mathrm{Al}^{3+}\right)=8,04-3 \mathrm{pH} \\
& \log \left(\mathrm{Fe}^{3+}\right)=2,7-3 \mathrm{pH} \\
& \log \left(\mathrm{Zn}^{2+}\right)=5,8-2 \mathrm{pH} \\
& \log \left(\mathrm{Cu}^{2+}\right)=2,8-2 \mathrm{pH} \\
& \log \left(\mathrm{MoO}_{4}^{2-}\right)=2 \mathrm{pH}-20,5
\end{aligned}
$$

Em todos esses casos, a solubilidade do metal (M) depende do $\mathrm{pH}$ (Kiekens, 1983). Porém, além do $\mathrm{pH}$, a estabilidade dos complexos é afetada pelo tipo do íon central e pelas propriedades do ligante (Filep, 1999). Para metais de transição com orbital d não saturado $\left(\mathrm{Mn}^{2+}, \mathrm{Mn}^{3+}, \mathrm{Fe}^{2+}, \mathrm{Fe}^{3+}, \mathrm{Co}^{2+}, \mathrm{Ni}^{2+}, \mathrm{Cu}^{2+}, \mathrm{Zn}^{2+}, \mathrm{Cr}^{3+}\right)$, as ligações coordenadas dativas são dominantes na formação dos complexos, e quanto maior o estado de oxidação, maior a estabilidade do complexo com o ligante (Filep, 1999).

A tendência de um determinado metal em formar complexos com um ligante pode ser explicada com auxílio no princípio dos ácidos e bases duros e moles (hard and soft acid and base ou HSAB). Um ácido de Lewis é qualquer espécie química que emprega um orbital eletrônico vazio no início da reação de complexação, enquanto uma base de Lewis é qualquer espécie química que emprega um orbital duplamente ocupado 
no início da reação de complexação. Os prótons e todos os cátions metálicos de interesse na solução do solo sã classificados como ácidos de Lewis (Tabela 3).

Tabela 3 . Representação de ácidos e bases duras e moles (Adaptada de Sposito, 1994)

\section{ÁCIDOS DE LEWIS}

\section{Ácidos Duros}

$\mathrm{H}^{+}, \mathrm{Li}^{+}, \mathrm{Na}^{+}, \mathrm{K}^{+},\left(\mathrm{Rb}^{+}, \mathrm{Cs}^{+}\right), \mathrm{Mg}^{2+}, \mathrm{Ca}^{2+}, \mathrm{Sr}^{2+},\left(\mathrm{Ba}^{2+}\right), \mathrm{Ti}^{4+}, \mathrm{Zr}^{4+}, \mathrm{Cr}^{3+}, \mathrm{Cr}^{6+}, \mathrm{Mn}^{4+}, \mathrm{Mn}^{3+}$, $\mathrm{Mn}^{2+}, \mathrm{Fe}^{3+}, \mathrm{CO}^{3+}, \mathrm{Al}^{3+}, \mathrm{Si}^{4+}, \mathrm{CO}_{2}$

\section{Ácidos Intermediários}

$\mathrm{Fe}^{3+}, \mathrm{CO}^{2+}, \mathrm{Ni}^{2+}, \mathrm{Cu}^{2+}, \mathrm{Zn}^{2+},\left(\mathrm{Pb}^{2+}\right)$

Ácidos Moles

$\mathrm{Cu}^{+}, \mathrm{Ag}^{+}, \mathrm{Au}^{+}, \mathrm{Cd}^{2+}, \mathrm{Hg}^{+}, \mathrm{Hg}^{2+}, \mathrm{CH}_{3} \mathrm{Hg}^{2+}$

\section{BASES DE LEWIS}

\section{Bases Duras}

$\mathrm{NH}_{3}, \mathrm{RNH}_{2}, \mathrm{H}_{2} \mathrm{O}, \mathrm{OH}^{-}, \mathrm{O}^{2-}, \mathrm{ROH}, \mathrm{CH}_{3} \mathrm{COO}^{-}, \mathrm{CO}_{3}{ }^{2-}, \mathrm{NO}_{3}{ }^{-}, \mathrm{PO}_{4}{ }^{3-}, \mathrm{SO}_{4}{ }^{2-}, \mathrm{F}^{-}$

Bases Intermediárias

$\mathrm{C}_{6} \mathrm{H}_{5} \mathrm{NH}_{2}, \mathrm{C}_{2} \mathrm{H}_{5} \mathrm{~N}, \mathrm{~N}_{2}, \mathrm{NO}_{2}^{-}, \mathrm{SO}_{3}{ }^{2-}, \mathrm{Br}^{-},(\mathrm{Cl})$

Bases Moles

$\mathrm{C}_{2} \mathrm{H}_{4}, \mathrm{C}_{6} \mathrm{H}_{6}, \mathrm{R}_{3} \mathrm{P},(\mathrm{RO})_{3} \mathrm{P}, \mathrm{R}_{3} \mathrm{As}, \mathrm{R}_{2} \mathrm{~S}, \mathrm{RSH}, \mathrm{S}_{2} \mathrm{O}_{3}{ }^{-}, \mathrm{S}^{2-}, \mathrm{I}^{-}$

$\mathrm{R}=$ unidade molecular orgânica; ( ) indica a tendência a se tornar mole

As bases de Lewis incluem $\mathrm{H} 0$; oxi-ânions tais como $\mathrm{OH}^{-}, \mathrm{COO}^{-}, \mathrm{CO}_{2}{ }^{-}, \mathrm{SO}_{4}{ }^{2-}$, $\mathrm{PO}_{4}{ }^{2-}$, e doadores de elétrons inorgânicos, como $\mathrm{N}, \mathrm{S}$ e P. O princípio do HSAB divide os ácidos e bases de Lewis em duas categorias:

a) Ácido de Lewis duro: unidade molecular de tamanho relativamente pequeno, elevado estado de oxidação, alta eletronegatividade e baixa polaridade. Apresentam elétrons externos relativamente difíceis de serem excitados a níveis mais elevados de energia. 
b) Ácido de Lewis mole: é relativamente grande em tamanho, reduzido estado de oxidação, baixa eletronegatividade e alta polaridade. Apresentam elétrons externos relativamente fáceis de serem excitados a níveis mais elevados de energia.

c) Base de Lewis dura: unidade molecular de elevada eletronegatividade e baixa polaridade. É difícil de oxidar e não apresenta orbitais vazios nos níveis inferiores de energia

d) Base de Lewis mole: mostra baixa eletonegatividade, alta polaridade e tendência à oxidação.

Porém, a separação das classes dos ácidos e bases não é bem clara. Existe uma mudança gradual com o aumento da polaridade dos ácidos de Lewis. Após a formação do complexo metal-ligante, outros ligantes podem competir para desestabilizá-lo e formar novos complexos com o cátion metálico (Sposito, 1994).

Segundo o princípio do HSAB, ácidos duros tem a tendência de formar complexos com bases duras, enquanto ácidos moles tem preferência por bases moles. Esse princípio, embora empírico, pode levar a conclusão que a especiação de elementos traços irá depender sensivelmente, por exemplo, do conteúdo e do tipo de matéria orgânica presente no solo.

A natureza e a concentração da solução do solo altera a atividade dos íons. Em geral, as espécies de "íons-livres" são biodisponívies, e sua determinação reflete o equilíbrio entre as diversas espécies químicas. Os "metais-livres" são as espécies mais tóxicas às plantas em relação às formas de complexos solúveis (McBride, 1995). Diversas metodologias têm sido desenvolvidas com o objetivo de quantificar a atividade dos “íons-livres" (Norvell, 1971; Gardiner, 1974; Baker et al., 1977; Fujii đ al., 1983; Amacher, 1984; Fitch \& Helmke, 1989; Hirsch \& Bonin, 1990).

Uma das opções para calcular a especiação química são os modelos computacionais. Esses modelos foram desenvolvidos inicialmente para soluções aquosas e são baseados em dados termodinâmicos. Porém, para o desenvolvimento de modelos geoquímicos para soluções em contato com as partículas de solo foi necessário 
considerar alguns processos, tais como reações de precipitação e dissolução, adsorção específica e troca de cátions (Ross, 1994). O primeiro modelo desenvolvido para soluções aquosas e solo foi o GEOCHEM (Sposito \& Mattigod, 1980). Mais tarde, Sposito \& Coves (1988) desenvolveram o SOILCHEM. Atualmente existe uma série de modelos para calcular a especiação iônica na solução do solo, tais como MINTEQ e MINEQL.

O GEOCHEM-PC (Sposito \& Mattigod, 1980; Parker et al., 1995) calcula a especiação de uma solução de equilíbrio, utilizando as constantes de estabilidade termodinâmicas e as concentrações totais dos metais e dos ligantes. Para cada componente da solução do solo, uma equação balanceada pelo número de mols é calculada, e as constantes termodinâmicas de equilíbrio são corrigidas de acordo com a força iônica da solução (Sposito, 1983). Uma das principais vantagens do uso do GEOCHEM-PC é a inclusão de um grande número de complexos e a possibilidade de prever a distribuição das espécies dos metais nos solos. Candelaria et al.(1997), estudando diferentes métodos para determinar a atividade de $\mathrm{Cd}$ na solução do solo, concluíram que a atividade do metal, em solos tratados com biossólidos, pode ser estimada com auxilio do GEOCHEM-PC. 


\section{MODIFICAÇÃO NO MÉTODO DE EXTRAÇÃO SEQÜENCIAL DE METAIS PESADOS PARA LATOSSOLOS E BIOSSÓLIDOS}

\section{Resumo}

A extração seqüencial de metais consiste numa ferramenta útil para estudar a distribuição de metais em frações quimicamente semelhantes em solos e em resíduos. Embora existam diversos métodos para realizar a extração seqüencial ou fracionamento químico de metais, a maioria deles não é adaptado para solos tropicais, com elevados teores de óxidos de $\mathrm{Fe}$ como os Latossolos. O objetivo desse estudo foi desenvolver um método de extração seqüencial de metais pesados, adequado para Latossolos e para biossólidos. A extração foi realizada em amostras superficiais e subsuperficias de dois solos do Estado de São Paulo: Latossolo Vermelho acriférrico (LVwf) e Latossolo Amarelo distrófico (LAd) e uma amostra da camada superficial de um Typic Xerorthent (BM), equivalente a um Neossolo Regolítico eutrófico na classificação brasileira, usada como referências devido à diferente constituição mineralógica; e duas amostras de biossólido (B-1974 e B-2001), coletadas na estação de tratamento de esgoto da cidade de Chicago, EUA em 1974 e em 2001, respectivamente. O método de extração seqüencial de metais modificado para os Latossolos e biossólido foi eficientemente capaz de extrair os metais ligados às frações trocável (Troc.), associados à superfície dos óxidos (Superf.Ox.), matéria orgânica (MO), óxidos de Mn (Ox.Mn), óxidos de Fe mal cristalizados (Fe Ox.); óxidos de Fe cristalinos (Fe crist.) e residual (Res). As frações óxidos de $\mathrm{Mn}$ e de $\mathrm{Fe}$ (mal cristalizados e cristalinos) foram dissolvidas satisfatoriamente com os reagentes. $\mathrm{O} \mathrm{Zn}$ e o $\mathrm{Cu}$ estiveram associados, principalmente, 
à fração Res, $\mathrm{Fe} \mathrm{Ox}$. e Fe crist. nos solos, enquanto nos biossólidos os óxidos de $\mathrm{Mn}, \mathrm{Fe}$ Ox. e Superf. Ox. foram mais importantes na retenção desses metais. Para $\mathrm{Cd}$, em todas as amostras, a fração Superf.Ox. destacou-se na retenção dos metais, com exceção do B2001, no qual a fração Ox.Mn foi a que reteve maior quantidade do metal. Não foi observada variação na distribuição de $\mathrm{Zn}$, de $\mathrm{Cu}$ e de $\mathrm{Cd}$ entre os horizontes $\mathrm{A}$ e $\mathrm{B}$ das amostras de terra. Para os biossólidos, a distribuição relativa dos metais nas frações foi semelhante, apesar de seus teores terem sido contrastantes.

\section{Summary: MODIFICATION OF A HEAVY METAL SEQUENTIAL EXTRACTION PROCEDURE FOR OXISOLS AND BIOSOLIDS}

The sequential extraction procedure can be useful to assess the metal distribution in soil and residues. Many methods have been proposed but, in generally, they are not suitable for tropical soils with high iron oxides contents, such as Oxisols. The objective of this study was to develop a heavy metal sequential extraction procedure, suitable for Oxisols and biosolids. The following materials were used: Surface soil samples (0-20 cm) from two Oxisols, a Rhodic Acrudox (RA) and a Typic Haplorthox (HA), a surface sample from a Typic Xerorthent (BM) and two biosolid samples from Sewage collected in 1974 (B-1974) and in 2001 (B-2001) in Chicago, USA. The modified procedure extracted metals associated with the fractions: exchangeable (Ex), surface oxides/carbonate (Surf.Ox.), organic matter (OM), Mn oxides (Mn Ox.), amorphous Fe oxide (Fe Ox.), crystalline $\mathrm{Fe}$ oxides (cryst. Fe) and residual (Res). The reagents dissolved satisfactorily the $\mathrm{Mn}$ and Fe oxides. Zinc and copper were mainly associated to Res, Fe Ox. and cryst. Fe fractions in the soils, while Mn Ox, Fe Ox. and Surf. Ox. were more important in the biosolid. The Surf.Ox. fraction was remarkable for $\mathrm{Cd}$ retention in all samples, except for the B2001, in which Mn. Ox were important. Zn, Cu and $\mathrm{Cd}$ distribution were similar in the surface and in the subsurface soil samples. For the biosolids, in spite of the different metal concentrations, their relative distribution was similar. 


\subsection{Introdução}

A concentração de metais no solo pode ser aumentada com o uso de resíduos industriais e municipais em áreas agrícolas e florestais. Porém, a concentração total de metais no solo pode não refletir sua biodisponibilidade (Lópes-Mosquera et al., 2000), e o fracionamento dos mesmos em frações específicas na fase sólida é uma importante ferramenta para prever os possíveis efeitos tóxicos no ambiente. Os metais, quando adicionados ao solo na forma sólida, tal como nos biossólidos, entram em equilíbrio com a solução, e, conseqüentemente, com a fase sólida. Esse equilíbrio é controlado, dentre outros fatores, pelas propriedades dos biossólidos e dos solos (Jing \& Longan, 1992; Petruzelli et al., 1994).

O principal do objetivo da extração seqüencial é medir seletivamente a distribuição de metais em sedimentos (Shannon \& White, 1991). Esse procedimento tem sido especialmente utilizado para determinar as formas dos metais adicionados ao solo via biossólido (Shuman, 1982). Teoricamente, os reagentes, o tempo de extração e a relação entre solo e solução utilizados na extração sequiencial são selecionados com o objetivo de solubilizar frações específicas da fase sólida com o mínimo de interferência nas demais frações. Apesar de existirem críticas aos métodos de extração sequiencial de metais, sobretudo relacionados à possibilidade de readsorção e redistribuição de metais durante as extrações, esse método possibilita a comparação entre metais ligados a frações similares do ponto de vista químico (Candelaria et al., 1997).

Diferentes métodos de extração seqüencial têm sido propostos (Tessier et al., 1979; European Community Bureau of References (BCR); Shuman, 1985; Ma \& Uren, 1998; Ahnstrom \& Parker, 1999). Os esquemas de extração não são padronizados, e várias modificações são realizadas para adaptar a metodologia às condições particulares.

A falta de uniformidade dos reagentes ou das condições experimentais torna muito difícil a comparação dos resultados (Arunachalam et al., 1996). Um esquema largamente utilizado por pesquisadores é o procedimento desenvolvido por Tessier et al. (1979), no qual os elementos traços são divididos nas fases trocável, ligados a carbonatos, óxidos de ferro e manganês, matéria orgânica e residual. A complexidade e o número de frações 
solubilizadas pode variar dependendo do procedimento. Por exemplo, Ma \& Uren (1998) propuseram um esquema de extração seqüencial no qual o metal estava associado a oito frações (solução do solo, trocável, extraído com EDTA, Mn facilmente redutível, carbonato, matéria orgânica, óxidos de $\mathrm{Fe}$ e $\mathrm{Al}$ e formas residuais). Todavia, esse procedimento mostrou-se extremamente trabalhoso, sendo necessária uma otimização sistemática da metodologia. Além da diferença entre os extratores, as condições experimentais nas quais as extrações são realizadas podem influenciar os resultados. Por exemplo, Zhang et al. (1998) estudaram dois métodos de extração de sequiencial de metais e obtiveram diferentes resultados quando utilizaram um mesmo reagente para remover a fração óxidos de $\mathrm{Fe}$ e $\mathrm{Mn}$, porém variando a temperatura e o modo de agitação. Arunachalam et al. (1996) encontraram diferenças na quantidade de Zn extraída com determinado reagente, porém submetidos ou à agitação horizontal ou à vertical. Além disso, dependendo do procedimento adotado e do seu respectivo grau de complexidade, a fração residual pode ser superestimada. Em geral, quanto mais simplificado, ou seja, quanto menor for o número de extrações, maior será a concentração do metal na fração residual. Arunachalam et al. (1996) observaram diferentes concentrações de $\mathrm{Mn}$ e Fe na fração residual de amostras de terra submetidas a dois métodos de extração seqüencial. A fração residual, em particular, pode ser calculada por diferença entre a somatória das demais frações e o teor total (LópezSánches et al., 1993), o que a torna mais suscetível ao acúmulo de erros experimentais.

A fração solúvel/trocável, presente na maioria dos procedimentos de extração sequiencial, é considerada a mais móvel e biodisponível das frações (Sastre et al., 2001). Em geral, essa fração é obtida com uso de soluções salinas diluídas, tais como cloreto de magnésio ou acetato de sódio. No caso de biossólidos, a extração das formas trocáveis de metais pode superestimar a biodisponibilidade, uma vez que a maior parte desses elementos pode se encontrar associada à fase coloidal, a qual é composta de partículas capazes de passar por um filtro de 0,45 $\mu \mathrm{m}$ e/ou moléculas maiores dissolvidas, lipofílicas, tais como as substâncias húmicas (Carlson-Ekvall \& Morrison, 1997). Os metais podem estar ligados nas superfícies dos óxidos ou associados aos carbonatos. Essa fração pode ser estimada por meio da extração com acetato de sódio (Lum et al., 
1982; Bradley \& Cox, 1987; Forstner, 1993). Obrador et al. (1997) encontraram correlação positiva entre a soma dos metais ligados às frações trocável + ligados às superfícies dos óxidos com DTPA. Esses autores concluíram que a soma dessas frações pode ser utilizada como estimativa da disponibilidade potencial de metais às plantas.

Além da fração trocável, os teores de matéria orgânica, óxidos de ferro e de manganês e de argila influenciam as reações de sorção de metais no solo (Barry et al., 1995). Metais tais como $\mathrm{Cd}^{+2}, \mathrm{Cu}^{+2}, \mathrm{~Pb}^{+2}$ and $\mathrm{Zn}^{+2}$, sob condições experimentais específicas, podem ser sequiestrados no interior das estruturas dos óxidos de ferro, seja pela interação das fases sólida e solução, resultando na formação de agregados com os óxidos, seja pela segregação na estrutura ou na superfície dos óxidos (Martinéz \& McBride, 1998). Os metais associados à essas frações são determinados utilizando diferentes reagentes que solubilizam especificamente cada um desses componentes.

Vários compostos são utilizados para extrair metais associados à fração matéria orgânica, tais como pirofosfato alcalino, $\mathrm{H}_{2} \mathrm{O}_{2}$ e $\mathrm{NaOCl}$. A técnica do pirofosfato apresenta algumas desvantagens, tais como a baixa repetibilidade, além de não apresentar seletividade para ferro e alumínio (Borggaard, 1985). Pode também ser empregada a $\mathrm{H}_{2} \mathrm{O}_{2}$ para solubilizar a matéria orgânica (Tessier et al., 1979), porém esse reagente pode também solubilizar óxidos de manganês. Uma alternativa para substituição do peróxido de oxigênio é o hipoclorito de sódio (5 a $6 \%$ ) a pH 8,5, que, nas condições citadas anteriormente, parece ser seletivo e capaz de remover completamente o carbono orgânico da amostra (Shuman, 1985).

Poucos trabalhos atentam para a associação de metais com óxidos de manganês facilmente redutível (Ma \& Uren, 1998). Porém, essa fração pode apresentar papel importante na retenção de metais. A extração pode ser feita com hidroxilamina cloridrato acidificada ( $\left.\mathrm{NH}_{2} \mathrm{OH} . \mathrm{HCl}\right)$ (Chao, 1972; Gilkes \& McKenzie, 1988; Krasnodebska-Ostrega et al., 2001). Outra opção é o uso de hidroxilamina-HCl-citrato para determinação dos metais associados às frações óxidos de ferro e manganês. Porém, a combinação desses reagentes pode não dissolver totalmente essas frações, sobretudo nos Latossolos, que apresentam elevado teor de óxidos de ferro cristalinos. Outra 
desvantagem desse método é que não é possível distinguir os metais associados aos óxidos de ferro mal-cristalizados ou aos óxidos de manganês.

Para os óxidos de ferro, vários procedimentos são apresentados com o objetivo de solubilizar essa fração, porém, em geral, esses métodos não separam os metais ligados às frações cristalinas e mal-cristalizadas, ou quando o fazem, como no trabalho de Shuman (1982), os solos estudados apresentam concentrações de ferro muito inferiores aos dos Latossolos. Deve-se ressaltar a importância da separação dos metais ligados aos óxidos de ferro com diferentes graus de cristalinidade, pois os óxidos de ferro mal-cristalizados são mais "ativos", do ponto de vista químico, no ciclo geoquímico de alguns elementos (Chao \& Zhou, 1983). O método do ascorbato-oxalato, desenvolvido por Shuman (1982), dissolve óxidos de ferro cristalinos e malcristalizados, porém, não é possível distinguir os metais associados a cada uma dessas frações. Por outro lado, o método do citrato-bicarbonato-dithionito (Mehra and Jackson, 1960), embora seja eficaz na remoção de formas cristalinas de óxidos de ferro, apresenta desvantagens, tais como a contaminação de zinco no ditionito de sódio, a formação de sulfitos que podem precipitar metais (Shuman, 1982), além da dificuldade da leitura dos extratos no espectrofotômetro de absorção atômica, devido ao constante entupimento do queimador do equipamento (Tessier et al., 1979). A técnica do $\mathrm{HCl}$ de remoção de óxidos de ferro cristalinos e mal-cristalizados, dependendo da concentração do ácido e tempo de equilíbrio, tem sido utilizada em vários trabalhos (Chao \& Zhou, 1983; Schwertmann, 1984). A habilidade do ácido clorídrico em dissolver ferro pode ser devida à formação de complexos entre $\mathrm{Fe}-\mathrm{Cl}$ na superfície dos óxidos, diminuindo a superfície de cargas positivas, o que ocasiona aumento da ação dos prótons em solução na dissolução os óxidos (Sidhu et al., 1981). Quanto aos óxidos de ferro malcristalizados, o método do oxalato inicialmente desenvolvido por Tamm (1922) e, posteriormente modificado por Schwertmann (1959), é utilizado para determinar metais ligados às formas amorfas e pouco cristalinas de óxidos de ferro em solos e minerais de argila. Esse procedimento é largamente utilizado em estudos de gênese e exploração geoquímica. O princípio do método do oxalato, o qual utiliza solução de oxalato de

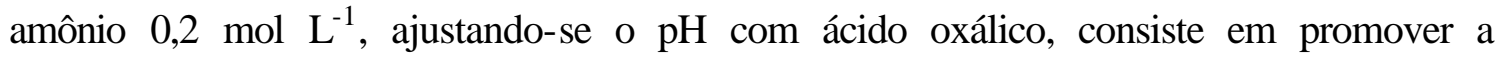


redução e, conseqüentemente, dissolução da ferridrita durante duas horas, sem reagir com formas cristalinas de óxidos de ferro, tais como goethita e hematita (Schwertmann, 1964). Esse procedimento deve ser procedido na ausência de luz, uma vez que formas cristalinas podem ser dissolvidas, além da degradação do reagente em tais circunstâncias. Embora se espere que os Latossolos apresentem baixos teores de óxidos mal-cristalizados, essa fração pode ser importante na retenção de metais nos biossólidos.

O objetivo desse trabalho foi desenvolver um método de extração seqüencial de metais pesados, adequado para Latossolos e para biossólidos.

\subsection{Material e Métodos}

Foram selecionadas sete amostras para realizar e otimizar o procedimento de extração seqüencial de metais: três amostras de terra de camadas superficiais, duas amostras de terra de subsuperfície (na maior expressão do horizonte B) e duas amostras de biossólidos. Os solos foram selecionados com base na granulometria e no teor de óxidos de ferro. As amostras LVwf-A e LVwf-B correspondem aos horizontes de superfície e subsuperfície, respectivamente, de um Latossolo Vermelho acriférrico (Typic Eutrorthox). As amostras LAd-A e LAd-B são horizontes de superfície e subsuperfície, respectivamente, de um Latossolo Amarelo distrófico (Typic Haplorthox). A amostra BM corresponde a um Typic Xerorthent, coletado em Solano County, Califórnia, equivalente a um Neossolo Regolítico eutrófico, na classificação brasileira de solos (Empresa Brasileira de Pesquisa Agropecuária, 1999). Essa amostra foi utilizada para comparar a eficiência do método em solos com diferentes composições mineralógicas. Os solos foram caracterizados conforme metodologia preconizada por Camargo et al. (1986) (Tabela 4).

O carbono orgânico foi analisado pela oxidação da matéria orgânica com solução de dicromato de potássio em presença de ácido sulfúrico e titulação do excesso de dicromato com sulfato ferroso amoniacal; o pH foi determinado em água, relação solosolução 1:2,5. 
Tabela 4. Atributos químicos e físicos das amostras de terra.

\begin{tabular}{|c|c|c|c|c|c|c|c|c|c|c|c|}
\hline Solo & $\mathrm{pH}$ & $\mathrm{C}$ & $\mathrm{Ca}$ & $\mathrm{Mg}$ & $\mathrm{K}$ & $\mathrm{Na}$ & $\mathrm{Al}$ & CTC & Areia & Silte & Argila \\
\hline & $\mathrm{H}_{2} \mathrm{O}$ & $\mathrm{g} \mathrm{kg}^{-1}$ & -----. & -------. & $-\mathrm{cmol}_{\mathrm{c}} \mathrm{C}$ & $n^{-3}-\cdots$ & - & -- & ---------- & $\mathrm{g} \mathrm{kg}^{-1}$ & ----- \\
\hline LVwf-A* & 5,0 & 20 & 40 & 17 & 5,8 & 0,1 & 0 & 62,9 & 170 & 230 & 600 \\
\hline LVwf-B* & 5,7 & 5,0 & 4 & 4 & 0,2 & 0 & 0 & 8,2 & 130 & 230 & 640 \\
\hline LAd-A & 4,0 & 8,3 & 0,4 & 0,1 & 0,02 & 0 & 1,43 & 2,0 & 830 & 50 & 120 \\
\hline LAd-B & 4,5 & 2,9 & 0,4 & 0,1 & 0,02 & 0 & 0,83 & 1,4 & 800 & 50 & 150 \\
\hline $\mathrm{BM}$ & 6,3 & ---- & 61 & 15 & 11 & 17 & 0 & - & 250 & 350 & 400 \\
\hline
\end{tabular}

$\mathrm{LVwf}=$ Latossolo Vermelho acriférrico; LAd= Latossolo Amarelo distrófico; $\mathrm{BM}=$ Typic Xerorthent; *A e B corresponde às amostras de superfície e subsuperfície, respectivamente.

$\mathrm{O}$ cátion trocável $(\mathrm{Ca}, \mathrm{Mg}, \mathrm{K}$ e $\mathrm{Na})$ utilizou-se resina trocadora de íons e posterior leitura no espectrofotômetro de absorção atômica (cálcio e magnésio)e no fotômetro de chama (potássio e sódio). A análise granulométrica foi realizada pelo método do densímetro.

As amostras de biossólido, designadas como B1974 e B-2001, são provenientes da estação de tratamento de esgoto da cidade de Chicago, EUA e foram coletadas em 1974 e em 2001, respectivamente. Outra distinção entre as amostras de biossólido é o sistema de tratamento empregado. Ambas amostras sofreram secagem ao sol, porém na amostra B-2001, foram utilizados polieletrólitos, enquanto na B-1974 empregou-se a compostagem.

Foram determinados os teores de Fe, Al e Mn "livres" (Meha \& Jackson,1960) e mal-cristalizados ou microcristalinos (Schwertmann, 1959) nas amostras de terra e biossólido (Tabela 5). O teor total de óxidos Fe foi obtido após digestão total da amostra com $\mathrm{HNO}_{3}, \mathrm{HF}$ e água deionizada (EPA 3052) $\left(\mathrm{HNO}_{3}, \mathrm{HF}\right.$ e água deionizada) (ESTADOS UNIDOS, 1996).

As amostras foram secas ao ar, moídas em mortar de ágata e peneiradas em peneiras de 100 mesh. Foram pesados aproximadamente $0,250 \mathrm{~g}$ de terra e 0,100 g de biossólido, e procedeu-se a digestão completa da amostra em microondas, utilizando o 
Tabela 5. Teores de óxidos (totais, livres e mal cristalizados).

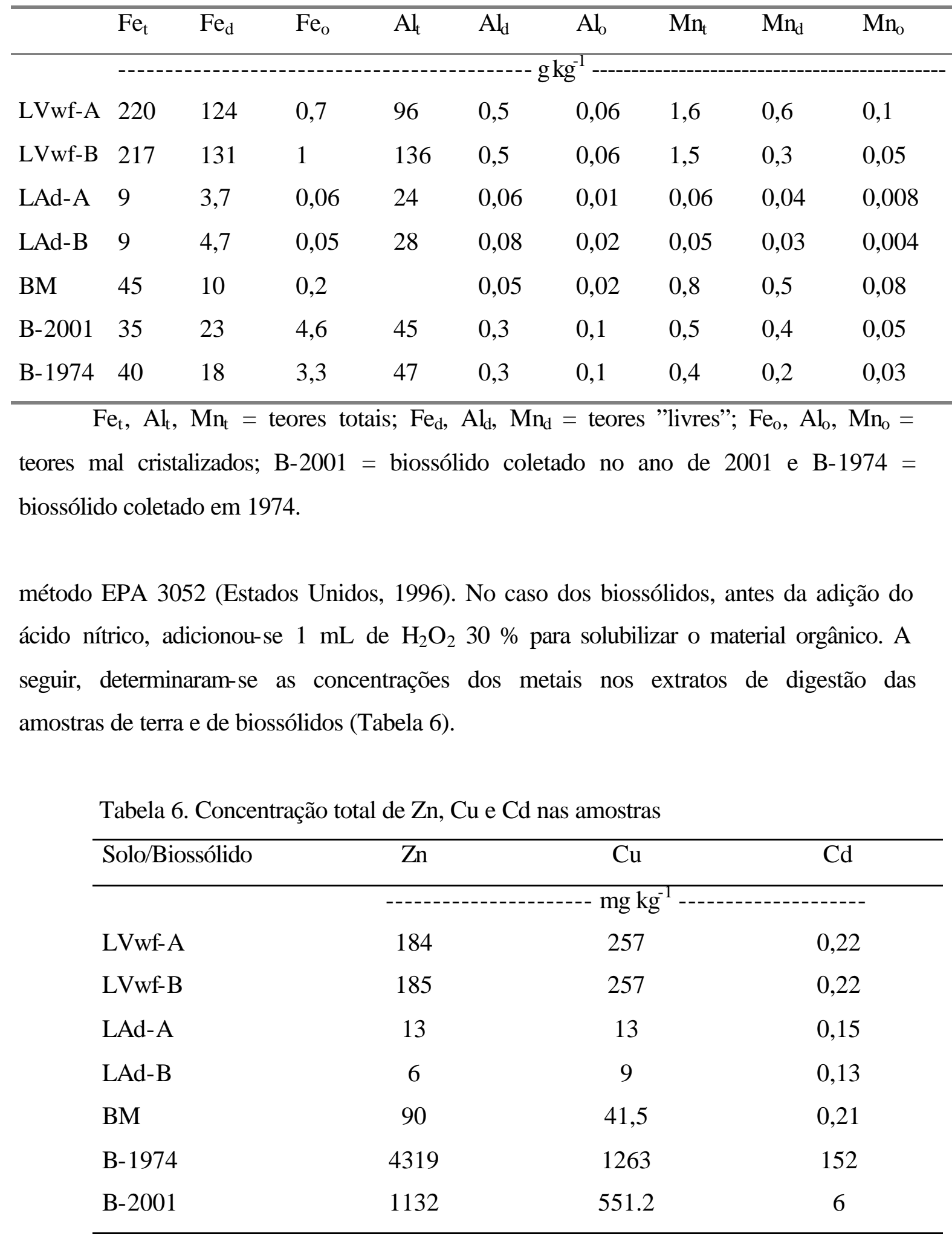


Para realizar a extração seqüencial, pesou-se o equivalente a $1 \mathrm{~g}$ do material seco (solo ou biossólido) e adicionou-se em tubos de centrífuga de policarbonato. Em seguida, procedeu-se às seguintes extrações:

1) Trocável (F1): as amostras foram equilibradas por 2 horas com $15 \mathrm{~mL}$ de $\mathrm{Sr}\left(\mathrm{NO}_{3}\right)_{2} \quad 0,1 \mathrm{~mol} \mathrm{~L}{ }^{-1}$. Agitaram-se por 2 horas em agitador horizontal, a temperatura ambiente. Essa extração foi baseada no trabalho de Ahnstrom \& Parker (1999), utilizando o mesmo reagente, tempo de equilíbrio e relação solo:solução equivalente. Embora existam vários tipos de reagentes para extrair a fração trocável, como $\mathrm{CaCh}$ ou $\mathrm{MgCh}_{2}$, o nitrato foi preferencialmente escolhido devido à habilidade do cloreto em formar complexos com os metais (Doner, 1978).

2) Adsorvido na superfície dos óxidos (F2): após $F 1$, as amostras reagiram com 15 de NaOAc 1,0 mol L ${ }^{-1}$, ajustado a pH 5 com ácido acético TMG (trace metal grade) (Lum et al., 1982; Bradley \& Cox, 1987). A suspensão foi agitada por 5 h da mesma forma descrita em F1.

3) Matéria Orgânica (F3): no resíduo proveniente de $F 2$ foram adicionados $5 \mathrm{~mL}$ of $\mathrm{NaOCl} 5 \%$, ajustado a $\mathrm{pH} 8,5 \mathrm{com} \mathrm{HCl}$ TMG. Os tubos de centrífuga foram colocados em banho-maria $\left(90^{\circ} \mathrm{C}\right)$ e reagiram por 30 minutos.

4) Óxidos de Mn (F4): Nessa extração, adaptou-se o procedimento empregado por Krasnodebska-Ostrega et al. (2001). O princípio desse método baseou-se na diferente solubilidade dos óxidos de ferro e manganês em $\mathrm{NH}_{2} \mathrm{OH} . \mathrm{HCl}$ acidificada. $\mathrm{O}$ resíduo de $\mathrm{F} 3$ foi extraído com $50 \mathrm{~mL}$ de $\mathrm{NH}_{2} \mathrm{OH} . \mathrm{HCl} 0,05 \mathrm{~mol} \mathrm{~L}^{-1}$ ajustado a pH 2 com HCl TMG. A suspensão foi agitada por 30 minutos em agitador horizontal.

5) Óxidos de Fe mal-cristalizados (F5): para determinar os metais ligados aos óxidos de ferro mal-cristalizados, utilizou-se o método do oxalato de sódio (Schwertmann (1964). Uma vez que o ferro extraído pelo oxalato é sensível à luz (Schwertmann, 1964), a extração foi desenvolvida no escuro, recobrindo-se os tubos de centrífuga com papel alumínio. No resíduo de $\mathrm{F} 4$ foram adicionados $40 \mathrm{~mL}$ de uma solução contendo oxalato de amônio $0,2 \mathrm{~mol} \mathrm{~L}^{-1}$ e ácido oxálico $0,2 \mathrm{~mol} \mathrm{~L}^{-1}$ ajustado o $\mathrm{pH}$ em 3,0. As amostras foram agitadas por $2 \mathrm{~h}$, de acordo com Schwertmann (1964). 
6) Óxidos de Fe cristalinos (F6): no resíduo de F5, foram adicionados $250 \mathrm{~mL}$ de $\mathrm{HCl} 6 \mathrm{~mol} \mathrm{~L}^{-1}$ e agitou-se a suspensão por 24 horas. Esse procedimento baseou-se em Schwertmann $(1983,1991)$.

7) Residual (F7): Após F6, o resíduo foi seco por congelamento e 2 subamostras de $0,25 \mathrm{~g}$ foram tomadas e procedeu-se a digestão total em microondas, de acordo com o método EPA 3052 (Estados Unidos, 1996).

Entre cada extração sucessiva, o resíduo foi suspenso em $5 \mathrm{~mL}$ de $\mathrm{NaCl} 0,1 \mathrm{~mol}$ $\mathrm{L}^{-1}$, para deslocar a solução anterior que poderia ter permanecido, reduzir a dispersão da amostra e limitar a readsorção do metal (Ahnstrom \& Parker, 1999). Todas as suspensões foram centrifugadas a $1225 \mathrm{~g}$ por $10 \mathrm{~min}$, e os supernadantes foram filtrados (Whatman \# 42). Os extratos de F1 a F3 foram acidificados a $1 \%$ com $\mathrm{HNO}_{3}$. Nos extratos de F4 e F5, foi adicionada uma gota de tolueno para evitar o crescimento de microorganismos. As concentrações de metais (Fe, $\mathrm{Mn}, \mathrm{Cu}$ and $\mathrm{Zn}$ ) foram determinadas com auxílio do espectrofotômetro de absorção atômica (chama de ar-acetileno). Os teores de $\mathrm{Cd}$ foram determinados em forno de grafite, acoplado ao mesmo espectrofotômetro descrito anteriormente. $\mathrm{Na}$ determinação de $\mathrm{Cd}$, foram adicionados os seguintes modificadores de matriz: $\mathrm{Mg}\left(\mathrm{NO}_{3}\right)_{2} 0,06 \%$ e $\mathrm{NH}_{4} \mathrm{H}_{2} \mathrm{PO}_{4} 1 \%$, para favorecer o processo de pirólise da amostra. Para garantir a exatidão das determinações, foram utilizados padrões certificados de água (NIST 1640- Trace elements in Natural Water) para verificar as leituras, além de padrões certificados de solo (NIST 2709- San Joaquin Soil) e biossólido (NIST 2781- Domestic Sludge), para avaliar o procedimento de digestão das amostras. O grau de recobrimento, calculado por meio da eq. (5), foi utilizado como critério de controle dos resultados obtidos na extração seqüencial e estipulo-se o limite máximo de erro tolerável igual a $\pm 15 \%$.

$$
\text { Recuperação }(\%)=\frac{\sum[\mathrm{M} \text {-frações }]}{[\mathrm{M} \text {-digestão total }]} * 100
$$

\subsection{Resultados e Discussão}


Os solos apresentam baixa fertilidade (Tabela 4). Os solos LVwf e LAd são pobres em cátions, sendo considerados ácricos. Isso se deve ao processo de intemperismo avançado nesses latossolos, que favoreceu a lixiviação de bases do perfil. Como esperado, os horizontes de superfície apresentaram maior concentração de cátions em relação aos de subsuperfície. Com relação à granulometria, o LVwf apresentou maior concentração de argila (textura muito argilosa), enquanto no LAd e no BM as frações grosseiras foram mais representativas. Esse comportamento refletiu, dentre outros fatores, nos valores de CTC dos Latossolos. O LVwf apresentou CTC aproximadamente trinta vezes superior ao LAd.

Os biossólidos apresentaram maior proporção de formas mal cristalizadas de óxidos em relação às formas livres $\left(\mathrm{Fe}_{\mathrm{o}} / \mathrm{Fe}_{\mathrm{d}}=0,2 ; \mathrm{Al}_{\mathrm{o}} / \mathrm{Al}_{\mathrm{d}}=0,33\right.$ e $\left.\mathrm{Mn}_{\mathrm{o}} / \mathrm{Mn}_{\mathrm{d}}=0,1\right)$ (Tabela 5). Nos solos, as amostras do LVwf apresentaram menores proporções de formas mal cristalizadas. Em média, encontrou-se $\mathrm{Fe}_{\mathrm{o}} / \mathrm{Fe}_{\mathrm{d}}=0,007 ; \mathrm{Al}_{\mathrm{o}} / \mathrm{Al}_{\mathrm{d}}=0,12 \mathrm{e}$ $\mathrm{Mn}_{\mathrm{o}} / \mathrm{Mn}_{\mathrm{d}}=0,2$. No LAd esses valores foram iguais a 0,02;0,2 e 0,2 para $\mathrm{Fe}, \mathrm{Al}$ e $\mathrm{Mn}$, respectivamente, enquanto no $\mathrm{BM}$ as proporções, seguindo a mesma ordem, foram iguais a 0,$02 ; 0,4$ e 0,2 .

As amostras de superfície e subsuperfície do LVwf apresentaram maiores teores de $\mathrm{Zn}$ (aproximadamente $\left.185 \mathrm{mg} \mathrm{k}^{-1}\right)$, de $\mathrm{Cu}\left(257 \mathrm{mg} \mathrm{k}^{-1}\right)$ e de $\mathrm{Cd}\left(0,22 \mathrm{mg} \mathrm{k}^{-1}\right)$ (Tabela 6). No LAd, as concentrações de metais, em mg kg-1, foram iguais a 13 para $\mathrm{Zn}$ e para $\mathrm{Cu}$ no horizonte $\mathrm{A}$ e 0,15 para $\mathrm{Cd}$. No horizonte $\mathrm{B}$ desse solo, os valores foram iguais a 6, 9 e $0,13 \mathrm{mg} \mathrm{kg}^{-1}$ de $\mathrm{Zn}, \mathrm{Cu}$ e $\mathrm{Cd}$, respectivamente. Ao contrário do observado por Kuo et al. (1983), em áreas próximas a mineração de cobre, não houve incremento na concentração de $\mathrm{Cd}$ com a profundidade em ambos os Latossolos. Para o BM, a concentração, em $\mathrm{mg} \mathrm{kg}^{-1}$, foi igual a 89 para o Zn, 41 para o $\mathrm{Cu}$ e 0,21 para o $\mathrm{Cd}$.

A concentração de metais nas amostras de biossólidos, em $\mathrm{mg} \mathrm{kg}^{-1}$, foi superior na amostra designada B-1974 (4319 de Zn, 1263 de $\mathrm{Cu}$ e 152 de Cd) em relação à amostra B-2001 (1132 para Zn, 551 para Cu e 6 para Cd) (Tabela 6). As amostras de biossólido apresentam a mesma origem, porém foram coletadas em épocas diferentes. Dentre outros fatores, a implementação da legislação nos Estados Unidos que controla os limites máximos de metais presentes no biossólido foi a principal razão na redução 
dos níveis de Zn, Cu e Cd nos resíduos coletados em 1974 (B-1974) e em 2001 (B2001). Os teores de metais pesados na amostra B-1974 foram bastante superiores aos encontrados por Sastre et al. (2001), em biossólido proveniente de descarga industrial. Especialmente para Cd, a concentração do metal na amostra B-1974 é aproximadamente duas vezes superior à obtida por esses autores. Em contrapartida, o biossólido B2001 apresenta teores de $\mathrm{Zn}$ e $\mathrm{Cu}$ semelhantes e de $\mathrm{Cd}$ inferiores aos obtidos por CarlsonEkvalll \& Morrison (1997) e Sastre et al. (2001) em biossólidos de origem urbana.

\subsubsection{Efeito da concentração da solução de $\mathrm{NH}_{2} \mathrm{OH}$.HCl na dissolução de óxidos de Mn}

Embora o método de dissolução de óxidos de $\mathrm{Mn}$ redutíveis em $\mathrm{NH}_{2} \mathrm{OH}$. $\mathrm{HCl}$ seja utilizado em diversos trabalhos (Chao, 1972; Gilkes \& McKenzie, 1988; KrasnodebskaOstrega et al., 2001), a concentração, o pH da solução extratora, o tempo de equilíbrio e a relação entre solo:solução variaram, dependendo do trabalho. A concentração e a acidez do extrator, além do tempo de equilíbrio, devem restringir a dissolução de óxidos de $\mathrm{Fe}$ e, ao mesmo tempo, serem suficientes para dissolver eficientemente os óxidos de Mn (Chao, 1972). Inicialmente, foram testadas duas concentrações da solução de $\mathrm{NH}_{2} \mathrm{OH} . \mathrm{HCl}\left(0,05 \mathrm{~mol} \mathrm{~L}^{-1}\right.$ e $\left.0,1 \mathrm{~mol} \mathrm{~L}^{-1}\right)$ nas amostras superficiais dos solos, pois nesta profundidade a concentração dos metais foi ligeiramente superior a de subsuperfície (Tabela 7). O tempo de extração e o pH ideal também foram avaliados.

A quantidade de Mn solubilizado não diferiu com o aumento na concentração de $\mathrm{NH}_{2} \mathrm{OH} . \mathrm{HCl}$ para as três amostras (Tabela 7). Resultados semelhantes foram obtidos por Krasnodebska-Ostrega et al. (2001). No LVwf-A, aproximadamente $22 \%$ do Mn total foi dissolvido em $\mathrm{NH}_{2} \mathrm{OH} . \mathrm{HCl}\left(0,05 \mathrm{~mol} \mathrm{~L}^{-1}\right)$, enquanto no LAd-A e no BM os valores foram iguais a 36 e $42 \%$ do $\mathrm{Mn}$ total, respectivamente. 
Tabela 7. Valores médios de Fe, Zn e Mn deslocados após 30 minutos de tratamento com $\mathrm{NH}_{2} \mathrm{OH} . \mathrm{HCl}$ ajustado a $\mathrm{pH} 2$.

\begin{tabular}{|c|c|c|c|c|c|c|}
\hline \multirow[b]{2}{*}{ Solos } & \multicolumn{2}{|c|}{$\mathrm{NH}_{2} \mathrm{OH} . \mathrm{HCl}$} & \multicolumn{2}{|c|}{$\mathrm{NH}_{2} \mathrm{OH} . \mathrm{HCl}$} & \multicolumn{2}{|c|}{$\mathrm{NH}_{2} \mathrm{OH} . \mathrm{HCl}$} \\
\hline & $0,05 \mathrm{~mol} \mathrm{~L}^{-1}$ & $0,1 \mathrm{~mol} \mathrm{~L}^{-1}$ & $0,05 \mathrm{~mol} \mathrm{~L}^{-1}$ & $0,1 \mathrm{~mol} \mathrm{~L}^{-1}$ & $0,05 \mathrm{~mol} \mathrm{~L}^{-1}$ & $0,1 \mathrm{~mol} \mathrm{~L}^{-1}$ \\
\hline & \multicolumn{2}{|c|}{$\mathrm{Fe}\left(\mathrm{mg} \mathrm{kg}^{-1}\right)$} & \multicolumn{2}{|c|}{$\mathrm{Zn}\left(\mathrm{mg} \mathrm{kg}^{-1}\right)$} & \multicolumn{2}{|c|}{$\operatorname{Mn}\left(\mathrm{mg} \mathrm{kg}^{-1}\right)$} \\
\hline LVwf-A & 93 & 133,8 & 3,75 & 2,7 & 340 & 430 \\
\hline LAd-A & 49 & 53 & 2,28 & 2,08 & 24,5 & 24,8 \\
\hline $\mathrm{BM}$ & 186,8 & 186,5 & 3,58 & 3,2 & 317,5 & 248,8 \\
\hline
\end{tabular}

Krasnodebska-Ostrega et al. (2001), utilizando a mesma concentração de $\mathrm{NH}_{2} \mathrm{OH} . \mathrm{HCl}$ citada anteriormente, obtiveram valores entre 26 a $35 \%$ do $\mathrm{Mn}$ total removido em amostras de terra de superfície e subsuperfície. Zhang et al. (1998), utilizando $\mathrm{NH}_{2} \mathrm{OH} . \mathrm{HCl}$ pH 2, obtiveram concentrações entre 20 a $40 \%$ do $\mathrm{Mn}$ total dissolvido em Molisols originários da China. Em sedimentos contendo óxidos de Mn mal cristalizados, Tipping et al. (1985) obtiveram cerca de $97 \%$ do Mn total removido por $\mathrm{NH}_{2} \mathrm{OH} . \mathrm{HCl}$. As quantidades de $\mathrm{Mn}$ que reagem e são dissolvidas em $\mathrm{NH}_{2} \mathrm{OH} . \mathrm{HCl}$ foram diferentes, dependendo das características das amostras, uma vez que essa fração representa os óxidos de Mn "ativos" do ponto de vista químico, tais como os minerais secundários de Mn. A quantidade Mn que permanece na amostra após a extração com $\mathrm{NH}_{2} \mathrm{OH} . \mathrm{HCl}$ e é dissolvida lentamente após extrações posteriores pode estar presente, sobretudo, como minerais primários ou formas não facilmente redutíveis (Chao, 1972).

A quantidade de Fe extraída aumentou com o aumento na concentração de $\mathrm{NH}_{2} \mathrm{OH} . \mathrm{HCl}$ para os Latossolos (LVwf e LAd). Na concentração mais alta de $\mathrm{NH}_{2} \mathrm{OH} . \mathrm{HCl}$, a concentração de $\mathrm{Fe}$ nos extratos variou entre 0,06 e 0,6 \% do ferro total para os três solos. Esses valores de Fe dissolvido foram inferiores aos encontrados por Krasnodebska-Ostrega et al. (2001). Esses autores obtiveram valores até $7 \%$ do Fe total dissolvido em $\mathrm{NH}_{2} \mathrm{OH} . \mathrm{HCl}$ 0,1 mol L-1 Tipping et al. (1985) encontraram até $10 \%$ do Fe total removido nesse extrator. Possivelmente, isso se deve ao diferente grau de cristalinidade e, conseqüentemente, de solubilidade dos óxidos de $\mathrm{Fe}$ das amostras de terra. A hematita, a goethita e a magnetita dissolvem moderadamente em $\mathrm{NH}_{2} \mathrm{OH} . \mathrm{HCl}$, 
porém formas amorfas de $\mathrm{Fe}(\mathrm{OH})_{3}$ podem ser mais facilmente dissolvidas (Chao, 1972). Finalmente, a quantidade de metal dissolvida, nesse caso indicada pela concentração de zinco em solução, não se mostrou dependente da concentração da solução extratora (Tabela 7). Na solução de $\mathrm{NH}_{2} \mathrm{OH}$. $\mathrm{HCl} 0,05 \mathrm{~mol} \mathrm{~L}^{-1}, 3,8 \%$ do $\mathrm{Zn}$ total foi dissolvido no LVwf-A; 2,3 \% no LAd-A e 3,6 no BM. Os resultados de Zn extraído foram inferiores aos obtidos por Krasnodebska-Ostrega et al. (2001), que obtiveram aproximadamente 19 $\%$ do $\mathrm{Zn}$ total removido em $\mathrm{NH}_{2} \mathrm{OH} . \mathrm{HCl} 0,05 \mathrm{~mol} \mathrm{~L}^{-1}$, em amostras de superfície. Tipping et al. (1985) obtiveram aproximadamente $95 \%$ do $\mathrm{Zn}$ total associado à fração óxidos de $\mathrm{Mn}$ em sedimentos de mineração de chumbo. Portanto, a solução de $\mathrm{NH}_{2} \mathrm{OH} . \mathrm{HCl} 0,05$ mol L${ }^{-1}$ acidificada com $\mathrm{HNO}_{3}$ a $\mathrm{pH} 2$ foi selecionada como a mais indicada para para dissolução de óxidos de Mn nas amostras de terra estudadas.

\subsubsection{Extração dos óxidos de Fe cristalinos e mal-cristalizados}

Diversos métodos e modificações foram testados com a finalidade de remover eficientemente os óxidos de ferro das amostras de terra e de biossólido e, conseqüentemente, determinar os metais ligados a essa fração. Uma breve descrição sobre os métodos testados está presente na Tabela 8.

As quantidades de Fe solubilizadas variaram dependendo do método utilizado e da amostra (Tabela 8). Para um mesmo método, a diferença na quantidade de $\mathrm{Fe}$ removida para cada amostra de terra pode ser devida a fatores como o grau de cristalinidade, a superfície específica e a taxa de substituição de $\mathrm{Al}^{3+}$ nos óxidos de $\mathrm{Fe}$ das amostras (Schwertmann, 1991). Para as amostras de terra, a proporção de óxidos de Fe mal-cristalizados em relação aos óxidos de $\mathrm{Fe}$ cristalinos foi marcadamente baixa $\left(\mathrm{Fe}_{\mathrm{o}} / \mathrm{Fe}_{\mathrm{d}}\right.$ entre 0,006 e 0,02) (Tabela 5), o que denota o elevado grau de cristalinidade dos óxidos de $\mathrm{Fe}$ nesses materiais. Já para as amostras de biossólido a relação $\mathrm{Fe}_{\mathrm{o}} / \mathrm{Fe}_{\mathrm{d}}$ variou entre 0,18 e 0,20 .

Em geral, o método do ditionito de sódio (T1) removeu de 56 e $60 \%$ do Fe nas amostras de superfície e subsuperfície do LVwf, 41 e $52 \%$ nas amostras do LAd e 22,5 \% do Fe total no BM (Tabela 9). O T1 foi um dos métodos mais eficiente na dissolução 
Tabela 8. Métodos para extração de óxidos de Fe

\begin{tabular}{|c|c|c|c|c|c|}
\hline $\begin{array}{c}\text { Tratamento/ } \\
\text { Extrator }\end{array}$ & Solução extratora & Solo:Solução & $\begin{array}{c}\text { Tempo } \\
\text { equilíbrio }\end{array}$ & $\begin{array}{c}\text { Condições } \\
\text { experimentais }\end{array}$ & $\begin{array}{c}\text { Referência } \\
\text { bibliográfica }\end{array}$ \\
\hline $\mathrm{T}_{1} /$ Ditionito & $\begin{array}{l}\text { Citrato tamponado + } \\
1 \mathrm{~g} \mathrm{Na}_{2} \mathrm{~S}_{2} \mathrm{O}_{4}\end{array}$ & $1: 30$ & $\begin{array}{l}15 \\
\text { minutos }\end{array}$ & $\begin{array}{l}90-95^{\circ} \mathrm{C}, \\
\text { agitando } \\
\text { ocasionalmente }\end{array}$ & $\begin{array}{l}\text { Meha \& } \\
\text { Jackson } \\
(1960)\end{array}$ \\
\hline $\mathrm{T}_{2} /$ Oxalato & $\begin{array}{l}0,2 \mathrm{~mol} \mathrm{~L}^{-1}\left(\mathrm{NH}_{4}\right)_{2} \mathrm{C}_{2} \mathrm{O}_{4}+ \\
0,2 \mathrm{~mol} \mathrm{~L}^{-1} \mathrm{C}_{2} \mathrm{O}_{4} \mathrm{H}_{2}, \mathrm{pH} 3\end{array}$ & $1: 40$ & 2 horas & $\begin{array}{l}\text { Agitador } \\
\text { horizontal, } \\
\text { escuro }\end{array}$ & $\begin{array}{l}\text { Schwertmann } \\
\text { (1959) }\end{array}$ \\
\hline $\mathrm{T}_{3} / \mathrm{HCl}$ & $6 \mathrm{M} \mathrm{HCl}$ & $1: 250$ & 24 horas & $\begin{array}{l}\text { Agitador } \\
\text { horizontal }\end{array}$ & $\begin{array}{l}\text { Schwertmann } \\
\text { (1984) }\end{array}$ \\
\hline $\begin{array}{l}\mathrm{T}_{4} / \text { Ácido } \\
\text { ascórbico- } \\
\text { oxalato }\end{array}$ & $\begin{array}{l}\text { Oxalato acima }+ \\
0,1 \mathrm{~mol} \mathrm{~L}^{-1} \quad \text { ácido } \\
\text { ascórbico }\end{array}$ & $1: 50$ & $\begin{array}{l}30 \\
\text { minutos }\end{array}$ & $\begin{array}{l}\text { Agitador } \\
\text { horizontal }\end{array}$ & $\begin{array}{l}\text { Shuman } \\
\text { (1982) }\end{array}$ \\
\hline $\begin{array}{l}\mathrm{T}_{5} / \text { Ácido } \\
\text { ascórbico- } \\
\text { oxalato }\end{array}$ & $\begin{array}{l}\text { Oxalato acima }+ \\
0,1 \text { mol } \mathrm{L}^{-1} \text { ácido } \\
\text { ascórbico }\end{array}$ & $1: 25$ & $\begin{array}{l}30 \\
\text { minutos }\end{array}$ & $\begin{array}{l}\text { Agitador } \\
\text { horizontal }\end{array}$ & $\begin{array}{l}\text { Ahnstrom \& } \\
\text { Parker } \\
\text { (1999) }\end{array}$ \\
\hline $\begin{array}{l}\mathrm{T}_{6} / \text { Ácido } \\
\text { ascórbico- } \\
\text { oxalato }\end{array}$ & $\begin{array}{l}\text { Oxalato acima }+ \\
0,1 \mathrm{~mol} \mathrm{~L}^{-1} \text { ácido } \\
\text { ascórbico }\end{array}$ & $1: 25$ & $\begin{array}{l}30 \\
\text { minutos }\end{array}$ & $\begin{array}{l}\text { Ultra-som + } \\
\text { Agitador } \\
\text { horizontal }\end{array}$ & Experimental \\
\hline $\begin{array}{l}\mathrm{T}_{7} / \text { Ácido } \\
\text { ascórbico- } \\
\text { oxalato }\end{array}$ & $\begin{array}{l}\text { Oxalato acima }+ \\
0,1 \mathrm{~mol} \mathrm{~L}^{-1} \text { ácido } \\
\text { ascórbico }\end{array}$ & $1: 25$ & 2 horas & $\begin{array}{l}\text { Agitador } \\
\text { horizontal }\end{array}$ & Experimental \\
\hline
\end{tabular}

de ferro das amostras, sobretudo nas que apresentavam os maiores conteúdos de ferro cristalino, tais como o LVwf-A e LVwf-B. A mudança na coloração da amostra de vermelha para amarela observada nas amostras submetidas ao T1 foi indicativo de que os óxidos de Fe "livres" foram preferencialmente solubilizados no início do processo de redução (Jeanroy et al., 1991). 
Tabela 9. Quantidade de Fe extraída a partir dos métodos.

\begin{tabular}{|c|c|c|c|c|c|}
\hline & \multicolumn{5}{|c|}{ Solos } \\
\hline Tratamentos & LVwf-A & LVwf-B & LAd-A & LAd-B & $\mathrm{BM}$ \\
\hline $\mathrm{T} 1$ & $123,9(56,3)^{*}$ & $130,6(60,2)$ & $3,7(40,9)$ & $4,3(52,5)$ & $10,1(22,5)$ \\
\hline $\mathrm{T} 2$ & $0,8(0,35)$ & $1,0(0,47)$ & $0,06(0,63)$ & $0,06(0,61)$ & $0,2(0,45)$ \\
\hline $\mathrm{T} 3$ & $138,0(62,7)$ & $139,3(64,2)$ & $2,6(29,2)$ & $2,0(22,44)$ & $10,2(22,5)$ \\
\hline $\mathrm{T} 4$ & $84,0(38,2)$ & $62,5(28,8)$ & $4,9(54,6)$ & $5,3(58,3)$ & $26(57,8)$ \\
\hline T5 & $17,1(7,8)$ & $17,1(7,9)$ & $1,0(11,3)$ & $0,6(7,1)$ & $12,3(27,3)$ \\
\hline T6 & $21,3(9,7)$ & $21,9(10,1)$ & $4,4(49,3)$ & $3,1(34,7)$ & $11,8(26,1)$ \\
\hline $\mathrm{T} 7$ & $10,5(4,8)$ & $10,9(5)$ & $0,9(9,6)$ & $0,9(10,2)$ & $13,4(29,7)$ \\
\hline
\end{tabular}

$\mathrm{T} 1=$ ditionito; $\mathrm{T} 2=$ oxalato; $\mathrm{T} 3=\mathrm{HCl} ; \mathrm{T} 4=$ ácido arcórbico+oxalato (relação solo:extrator 1:50); T5= ácido arcórbico+oxalato (relação solo:extrator 1:25); T6= idem T5, porém uso ultra-som; T6=idem T5, porém tempo de equilíbrio de 2 horas.

* Concentração de Fe entre parênteses refere-se a \% do total.

O método T2, usualmente utilizado para solubilizar formas mal-cristalizadas de óxidos de $\mathrm{Fe}$, resultou nas menores concentrações de $\mathrm{Fe}$ dissolvido $(<1 \%$ do $\mathrm{Fe}$ total para as cinco amostras) (Tabela 9). Isso se deve, novamente, ao elevado grau de cristalinidade dos óxidos de Fe dessas amostras. O T3 foi o mais eficiente na remoção de $\mathrm{Fe}$, sobretudo nas amostras que apresentaram maior concentração desse metal (LVwf-A e LVwf-B). Aproximadamente $63 \%$ do Fe foi removido no LVwf-A e $64 \%$ no LVwfB. No LAd-A a quantidade de Fe solubilizada foi igual a $29 \%$ e $22 \%$ do Fe total no LAd-B. Para o BM esse valor foi igual a $27 \%$ do Fe total. Schwertmann (1991) obteve diferentes taxas de dissolução de $\mathrm{Fe} \mathrm{HCl} 6 \mathrm{~mol} \mathrm{~L}^{-1}$ a $25^{\circ} \mathrm{C}$ em solos tropicais goetíticos/hematíticos, sendo que, para algumas amostras, dependendo do grau de substituição de $\mathrm{Al}^{3+}$, aproximadamente $60 \%$ do $\mathrm{Fe}$ foi dissolvido após oito dias de equilíbrio.

A eficiência do oxalato-ácido ascórbico (T4) mostrou ser dependente das características da amostra. Nas amostras do LAd, quando se utilizou a maior relação 
entre solo:extrator, esse método mostrou-se mais eficiente do que os demais, resultando na dissolução de aproximadamente 55 e $58 \%$ do Fe total nas amostras de superfície e subsuperfície, respectivamente. No LVwf-A, $38 \%$ do Fe total foi removido no horizonte A e $28 \%$ no horizonte B, enquanto para o BM foram dissolvidos $27 \%$ do Fe total (T4). Porém, a quantidade de Fe removida em todas as amostram no T4 foram bastante inferiores às obtidas por Shuman (1982), que observou de 67 a $100 \%$ do Fe total removido em três amostras de solos. Porém, as amostras de terra estudadas por Shuman (1982) apresentavam teor total de Fe variando entre 0,24 e 3,19 \%, que são concentrações bastante inferiores às das amostras estudadas no presente trabalho.

Quando se utilizou a menor relação solo:extrator, ou seja, 1:25 (T5), as quantidades de Fe dissolvidas foram iguais a $8 \%$ do Fe total em ambas as amostras do LVwf, 11 e $5 \%$ no LAd-A e no LAd-B, respectivamente, e $27 \%$ no BM. Esses resultados sugerem que a quantidade de reagente não foi suficiente para dissolver completamente os óxidos de Fe cristalinos presentes nas amostras. $\mathrm{O}$ efeito do ultra-som (T6) só foi evidente para as amostras do LAd, nas quais $49 \%$ do Fe foi dissolvido no horizonte A e 35 no horizonte $\mathrm{B}$. Isso se deve, possivelmente, a granulometria grosseira desse solo, sendo que o tratamento prévio com auxílio de ultra-som favoreceu a maior área de contato entre as partículas de solo e o reagente. Oorschot \& Dekkers (1999) obtiveram resultados semelhantes e concluíram que o ultra-som pode favorecer a dispersão e reduzir o diâmetro médio dos agregados.

Comparando os resultados obtidos em T5 e T7, observou-se que o aumento no tempo de equilíbrio da reação de 30 minutos para 2 horas não resultou em maior quantidade de Fe dissolvida. Para o LVwf-A e para o LVwf-B, que apresentam os maiores conteúdos de $\mathrm{Fe}$, os tratamentos T4 a T6 não foram eficientes na remoção de $\mathrm{Fe}$ das amostras, e os metais associados à essa fração podem ser subestimados, pois não houve a dissolução completa dos óxidos.

A eficiência dos tratamentos T4 aT7 foi favorecida com aumento do número de extrações com a solução oxalato-ácido ascórbico (Figura 2). 


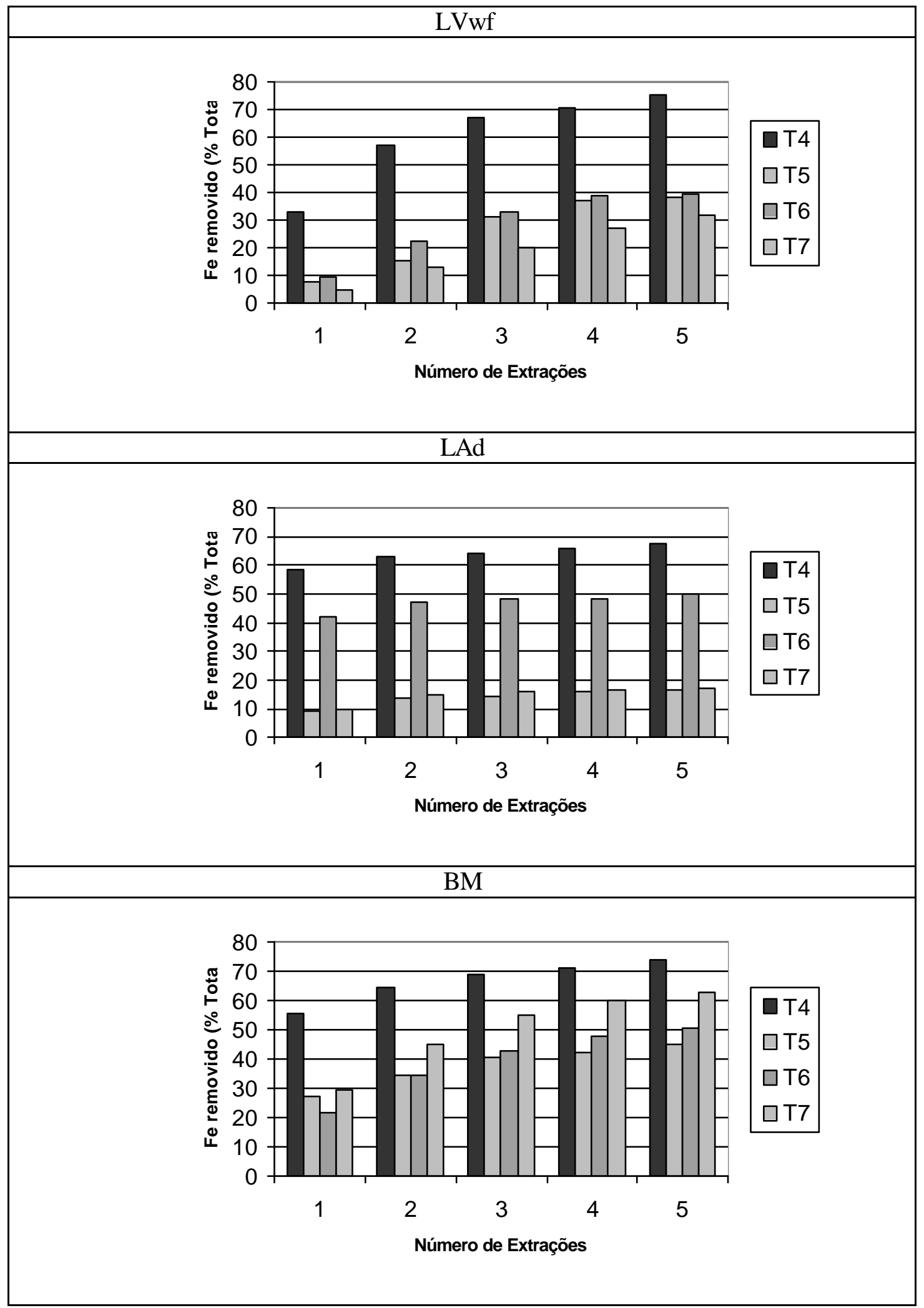

Figura 2 - Remoção de óxidos de Fe, após cinco extrações seqüenciais. 
Após cinco extrações seqüenciais, o T4 foi o tratamento mais eficiente na remoção de Fe. Foram removidos $75 \%$ do Fe total no LVwf, 67 \% no LAd e 67 \% no BM. Comparando as quantidades de Fe extraídas após uma extração (Tabela 9) e após cinco extrações (Figura 2), nota-se que o aumento no número de extrações promoveu um aumento de aproximadamente $97 \%$ na quantidade Fe extraída no LVwf (uma extração = $38 \%$ do Fe total; cinco extrações $=\hbar \%$ do Fe total). Para o LAd esse aumento foi igual a $22 \%$ no Fe extraído (55 \% do Fe total obtido após uma extração e $67 \%$ após cinco extrações), enquanto para o BM, o incremento foi da ordem de $28 \%$ (58 \% do $\mathrm{Fe}$ total para $74 \%)$.

O tratamento T5 removeu 38, 17 e $45 \%$ do Fe total no LVwf, LAd e BM, respectivamente. No T6 as concentrações de Fe foram iguais a $40 \%$ do Fe total no LVwf, $50 \%$ para LAd e para BM. Finalmente, para o T7, a quantidade de Fe removida não diferiu do T5, sendo igual a $32 \%$ do Fe total no LVwf, $17 \%$ no LAd e $62 \%$ no BM.

Devido ao número excessivo de extrações necessário para dissolver eficientemente os óxidos de Fe das amostras, o método de remoção de óxidos de Fe desenvolvido por Shuman (1982) (T4) e suas modificações (T5 a T7) não foram considerados apropriados para serem utilizados na extração seqüencial de metais.

Outra opção testada foi a combinação dos métodos do oxalato (T2) e do $\mathrm{HCl}$ (T3) com o objetivo de solubilizar seletivamente os óxidos de Fe mal cristalizados e cristalinos, respectivamente. Após o tratamento com os reagentes, realizou-se a análise com auxílio do difratograma de raios- $\mathrm{X}$ de duas amostras originais, ou seja, sem remoção dos óxidos de Fe, após o tratamento utilizando T2 + T3 e após o tratamento com ditionito de sódio (T1), como parâmetro de comparação da eficiência do método. A eficiência do tratamento $\mathrm{T} 2+\mathrm{T} 3$ em solubilizar os óxidos de Fe foi semelhante à do T1 (Figura 3). Os picos dos óxidos de Fe e Al foram reduzidos no LVwf, sem que houvesse interferência nos minerais tais como caulinita e quartzo, embora se saiba da associação nos solos entre goethita e hematita com gibbsita, caulinita e quartzo (Pinheiro-Dick \& Schwertmann 1996). No LAd não foram detectados picos relacionados aos óxidos de Fe, 
possivelmente, pela limitação do método de não detectar minerais presentes em

LVwf

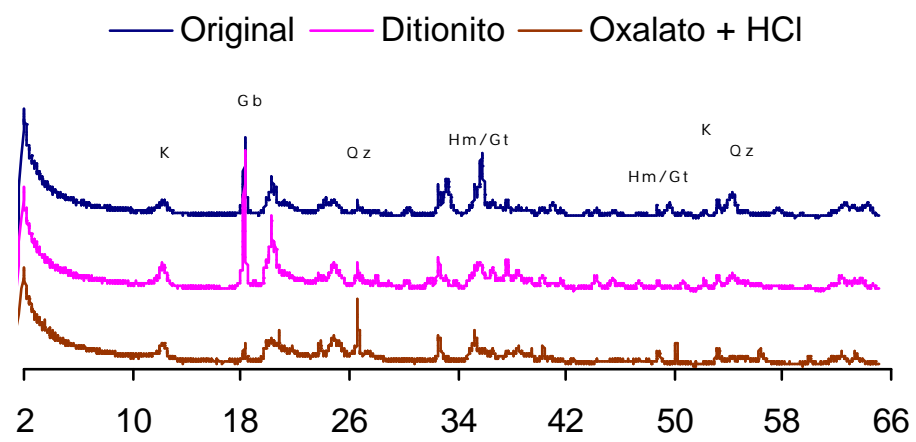

LAd

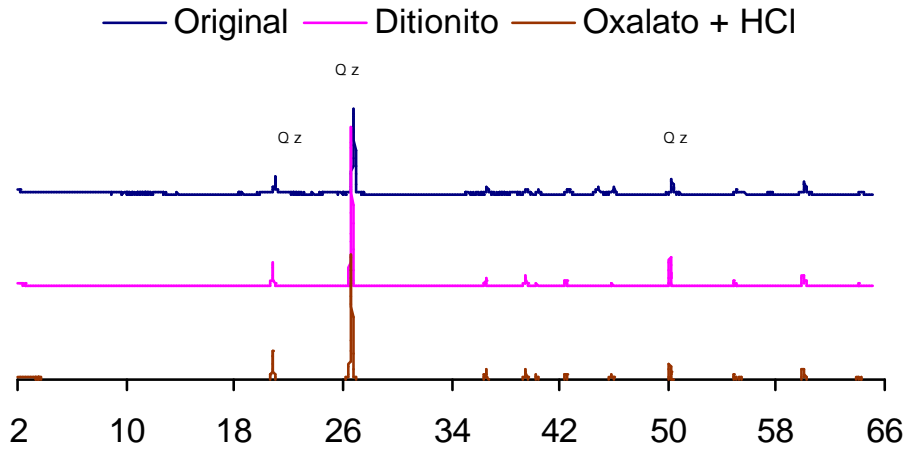

Figura 3 - Resultados do difratograma de raios-X nas amostras de terra originais e tratadas com ditionito de sódio (T1) e oxalato $+\mathrm{HCl}(\mathrm{T} 2+\mathrm{T} 3)$.

$\mathrm{K}=$ caulinita $; \mathrm{Gb}=$ gibbisita; $\mathrm{Qz}=$ quartzo; $\mathrm{Hm}=$ hematita e $\mathrm{Gt}=$ goethita.

concentrações inferiores a $1 \%$ (base em massa) do total. Nessa amostra foram identificados apenas os picos típicos do quartzo. Embora seja difícil distinguir dentre os picos dos óxidos de $\mathrm{Fe}$, sugere-se que a hematita é mais facilmente dissolvida devido à menor substituição por Al do que a goethita (Jeanroy et al., 1991). A combinação dos tratamentos oxalato $+\mathrm{HCl}$ não provocou a dissolução da caulinita, possibilitando que na fração residual fossem extraídos os metais ligados aos minerais secundários e ao quartzo. 
A combinação dos métodos do oxalato (T2), seguido do $\mathrm{HCl}$ (T3), parece ser uma opção viável, considerando o número de extrações, o tempo e a seletividade dos reagentes em dissolver formas cristalinas e mal-cristalizadas de Fe, para ser empregado na metodologia de extração seqüencial de metais, em solos com elevado teor de óxidos de Fe, tais como os Latossolos. Além disso, os extratos podem ser facilmente analisados no espectrofotômetro de absorção atômica, no forno de grafite ou no ICP, sem os inconvenientes do método do ditionito de sódio ou do número excessivo de extrações do método do oxalato-ácido ascórbico.

\subsubsection{Recuperação de $\mathrm{Zn}$, Cu e $\mathrm{Cd}$ nas amostras submetidas a extração seqüencial}

Em geral, a recuperação de $\mathrm{Zn}, \mathrm{Cu}$ e $\mathrm{Cd}$ nas amostras que sofreram a extração seqüencial, calculada de acordo com a equação 5, encontrou-se dentro do limite de erro $( \pm 15 \%)$ (Tabela 10).

Tabela 10. Recuperação dos metais após a extração seqüencial (valores em \%).

\begin{tabular}{lccc}
\hline Amostras & Zn & $\mathrm{Cu}$ & $\mathrm{Cd}$ \\
\hline LVwf-A & 97 & 102 & 106 \\
LVwf-B & 104 & 102 & 108 \\
LAd-A & 71 & 71 & 109 \\
LAd-B & 108 & 80 & 103 \\
BM & 104 & 107 & 109 \\
B-1974 & 91 & 91 & 81 \\
B-2001 & 97 & 109 & 98 \\
\hline
\end{tabular}

Os menores valores de recuperação foram obtidos na amostra do LAd-A, na qual a recuperação de $\mathrm{Zn}$ e $\mathrm{Cu}$ foi de $71 \%$ (Tabela 10). Nessa amostra, embora recuperação de $\mathrm{Zn}$ tenha sido inferior ao erro máximo de $15 \%$, os valores absolutos de $\mathrm{Zn}$ e $\mathrm{Cu}$ obtidos via digestão total (13- $\mathrm{mg} \mathrm{kg}^{-1}$ de $\mathrm{Zn}$ e de $\mathrm{Cu}$ ) e pelo cálculo da soma das frações (9- $\mathrm{mg} \mathrm{kg}^{-1}$ de $\mathrm{Zn}$ e de $\mathrm{Cu}$ ) foram bastante semelhantes. Devido à baixa concentração de 
metais nessa amostra, uma pequena diferença entre a soma das frações e o valor total representou um erro proporcionalmente maior em relação às amostras com maior concentração de metais. Embora a recuperação tenha sido inferior a $15 \%$ nas amostras LAd-A, esses valores foram considerados satisfatórios para discussão dos resultados. Uma vez que o critério de recuperação foi atendido, os valores de distribuição dos metais nas frações foram expressos em termos de porcentagem do total.

\subsubsection{Distribuição de Zn nas frações}

A distribuição de $\mathrm{Zn}$ nos solos seguiu a seguinte ordem:

- LVwf-A : Res> Fe crist $>$ Fe-Ox> Ox.Mn $>$ Superf. Ox.

- LVwf-B: Res $>$ Fe crist $>$ Fe Ox> Ox. Mn

- LAd-A: Fe Ox > Ox.Mn > Troc. > Surf. Ox.

- LAd-B: Fe Ox > Ox.Mn > Superf. Ox.

- BM: Res> Fe Ox > Ox.Mn

- B-1974: Ox.Mn $>$ Superf. Ox. $=$ Fe crist $>$ Fe-Ox $>$ MO $>$ Troc.

Nas amostras de terra, o Zn foi encontrado principalmente relacionado à fração óxidos de $\mathrm{Fe}$ (mal cristalizados ou cristalinos) e residual (Figura 4). Esses resultados concordam com os obtidos por Shuman (1985), nos quais o $\mathrm{Zn}$ foi encontrado, preferencialmente, ligado aos óxidos de Fe do que aos óxidos de Mn. Porém, de 1,4 a $32,1 \%$ (média de 12,9 \%) do $\mathrm{Zn}$ foi associado à fração óxidos de Mn. Esses valores corroboram os obtidos por Iyengar et al. (1981), porém são superiores aos obtidos por Zhang et al. (1998). Esses últimos autores encontraram de 4,5 a 8,8 \% do $\mathrm{Zn}$ total associado aos óxidos de Mn, em solos com teores de Mn variando entre 138 e $413 \mu \mathrm{g} \mathrm{g}^{-1}$ de Mn. Embora o teor de Mn nos solos estudados por Zhang et al. (1998) se encontrem na mesma faixa de concentração dos solos do presente estudo, as quantidades de $\mathrm{Zn}$ obtidas nessa fração foram diferentes. Sugere-se, então, que não apenas o teor de óxidos 


\section{Solos}

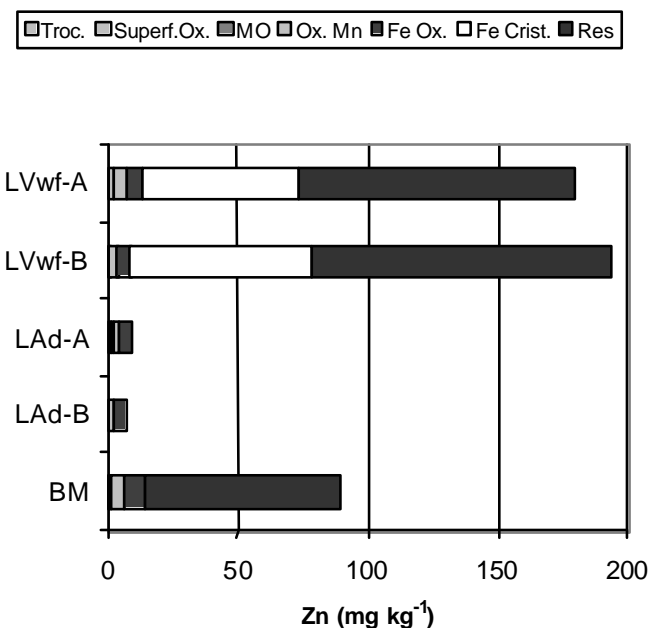

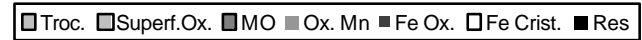

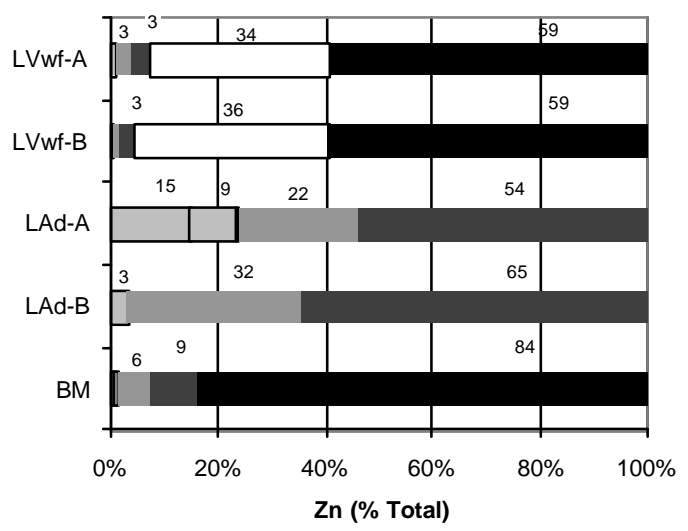

Biossólidos
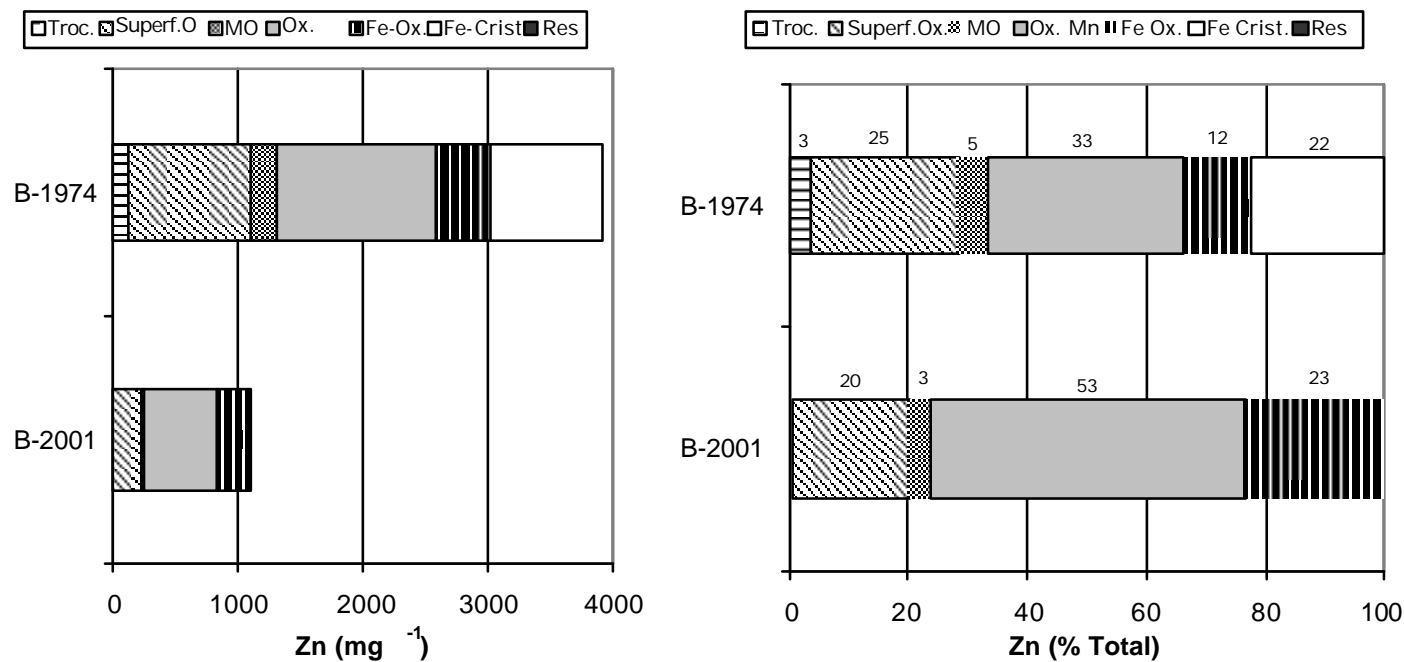

Figura 4 - Distribuição de Zn nos solos e nos biossólidos 
de Mn seja importante na adsorção de $\mathrm{Zn}$, mas também a reatividade dessa fração. Embora a absorção de metais seja influenciada por diversos fatores, e a relação entre a mesma e determinada fração do solo seja difícil de ser calculada, Zhang et al. (1998) encontraram correlação entre teor de $\mathrm{Zn}$ em raízes de milho e o determinado na fração óxidos de Fe e Mn.

Em ambos os horizontes do LVwf, a fração trocável (Troc.) e ligado à matéria orgânica (MO) foram inferiores a $1 \%$ do total. Sposito et al. (1982b), estudando solos tratados com biossólido, encontraram valores entre 1,6 e 1,7\% do $\mathrm{Zn}$ total associado à fração solúvel + trocável (extraídos com $\mathrm{KNO}_{3}+\mathrm{H} \mathrm{O}$ ). No LVwf, de 93 a 96 \% do Zn foi encontrado nas frações Res e Fe crist., que correspondem às frações do metal ligado aos minerais primários, aos secundários e às formas cristalinas de óxidos de ferro. Nessas frações, o zinco pode encontrar-se absorvido ou ocluso no interior das estruturas cristalinas, não sendo disponível às plantas. Shuman (1985) encontrou resultados semelhantes para solos do estado da Geórgia (EUA), nos quais o Zn estava associado principalmente aos óxidos de Fe cristalinos e à fração residual. Iyengar et al. (1981) estudaram 19 solos do estado da Virginia (EUA) e observaram que, em média, $70 \%$ do Zn nativo desses solos se encontravam na fração residual. Kuo et al. (1983) avaliaram 19 amostras de terra, coletadas em diversas profundidades, e observaram que entre 30 e 87 $\%$ do $\mathrm{Zn}$ estava associado à fração residual.

No LAd, a fração Fe Ox. foi responsável por aproximadamente $54 \%$ do Zn total no horizonte A e $65 \%$ no B. Esses resultados corroboram os obtidos por Kuo et al. (1983), que encontraram entre 35 e $57 \%$ do $\mathrm{Zn}$ total associado com a fração óxidos de Fe mal cristalizados. Obrador et al. (1997) observaram que a maior porcentagem do $\mathrm{Zn}$ foi obtida na fração extraída com solução de oxalato, correspondente à fração Fe Ox.. Porém, como não houve o tratamento prévio da amostra com hidroxilamina no trabalho de Obrador et al. (1997), não se pode distinguir se essa fração corresponde aos óxidos de Fe mal cristalizados e/ou óxidos de Mn. A maior importância relativa na fração Fe-Ox no LAd deve-se a maior concentração de formas mal cristalizadas de ferro (maior relação Fe-oxalato / Fe-ditionito) em relação aos demais solos (Tabela 5). Como citado anteriormente, os óxidos de ferro mal-cristalizados são considerados mais "ativos" do 
ponto de vista químico no ciclo (Chao \& Zhou, 1983), e os metais ligados à essa fração podem ser mais facilmente absorvidos pelas plantas.

Para o BM cerca de $84 \%$ do $\mathrm{Zn}$ estava associado à fração residual. Em seguida, as frações Fe Ox. e Ox. Mn representaram aproximadamente $14 \%$ do $\mathrm{Zn}$ total. As demais frações foram inferiores a $1 \%$ do total. Devido à composição mineralógica desse solo, composta sobretudo por minerais de argila do tipo 2:1, a fração residual desempenhou importante papel na retenção de $\mathrm{Zn}$ nesse solo. Iyengar et al. (1981) encontraram até $90 \%$ do $\mathrm{Zn}$ total associado à fração residual, dependendo das características químicas e mineralógicas dos solos. Bradley \& Cox (1987) obtiveram, em sedimentos de rios, até $95 \%$ do $\mathrm{Zn}$ total presente na fração residual.

Nos biossólidos, embora a concentração de Zn na amostra B1974 tenha sido quase quatro vezes superior à concentração na amostra B2001, a distribuição do metal foi semelhante (Figura 4). Aproximadamente $77 \%$ do $\mathrm{Zn}$ estava associado às frações Mn e Fe Ox no B-2001, enquanto no B-1974, 67 \% do Zn foi encontrado nas frações Mn $+\mathrm{Fe} \mathrm{Ox}+\mathrm{Fe}$ crist. Para ambas as amostras de biossólido, a fração trocável foi desprezível (0,4 \% do Zn total no B-2001 e 3 \% no B-1974). Esses valores são semelhantes aos obtidos por Petruzzelli et al. (1994), que encontraram valores variando entre 1,0-3,6 \%, e 0,06-0,50 \% do total de Zn extraído nas frações solúvel + trocável para duas amostras de biossólido. Não foi detectado $\mathrm{Zn}$ associado à fração residual para ambos os biossólidos.

\subsubsection{Distribuição de Cu nas frações}

A distribuição de $\mathrm{Cu}$ nos solos seguiu a seguinte ordem:

- L R-A : Res> Fe crist > > Ox.Mn> Fe Ox> Superf. Ox.= MO

- LVwf-B: Res> Fe crist > Ox.Mn > Fe Ox= Superf. Ox.

- LAd-A: Fe Ox > Ox.Mn> Troc. > Surf. Ox.

- LAd-B: Fe Ox > Ox.Mn > Superf. Ox.> Troc.

- BM: Res $>$ Fe crist $>$ Ox.Mn $>$ Fe $\mathrm{Ox}=\mathrm{MO}$

- B-1974: Ox.Mn> Fe-Ox > MO> Superf. Ox .= Res $>$ Fe crist 
- B-2001: Fe-Ox = Res > MO> Ox.Mn > Fe crist > Superf. Ox.

Nas amostras de terra, o $\mathrm{Cu}$ foi encontrado relacionado principalmente às frações residual e óxidos de ferro (Figura 5). Com exceção das amostras LAd-A e LAd-B, a fração Cu-trocável nas demais amostras foi igual a zero. Esses resultados concordam com os obtidos por Sposito et al. (1982b), que obtiveram valores de Cu associado à fração solúvel + trocável inferior a $4 \%$ do Cu total. Bradley \& Cox (1987) encontraram entre 0,2 e $10 \%$ (média $=1,5 \%$ ) do $\mathrm{Cu}$ total associado à fração trocável. Embora possa haver migração e perdas de $\mathrm{Cu}$ (McBride et al., 1997), as baixas concentrações de $\mathrm{Cu}$ encontrados nas frações trocáveis dos solos e dos biossólidos revelam que, nessas condições, o metal não pode ser facilmente lixiviado. Por outro lado, Zhang et al.(1998) não encontraram correlação entre o teor de $\mathrm{Cu}$ em diferentes partes da cultura de milho e as frações extraídas no solo.

No LVwf, a fração residual representou $79 \%$ do $\mathrm{Cu}$ no horizonte $\mathrm{A}$ e $86 \%$ no horizonte B (Figura 5). No BM, cerca de $45 \%$ do Cu estava associado à fração residual. Nesse mesmo solo as frações Fe crist e Mn representaram entre 18 e $20 \%$ do $\mathrm{Cu}$ total. Já para as amostras do $\mathrm{LAd}$, o $\mathrm{Cu}$ encontrou-se principalmente ligado às frações $\mathrm{Fe}-\mathrm{Ox}$ e Ox. Mn. No LAd-A a soma dessas frações foi aproximadamente $76 \%$ do Cu total e no LAd-B ao redor de 91\%. Kuo et al. (1983), estudando amostra de terra de horizontes de superfície e subsuperfície, observaram que entre 70 e $82 \%$ do $\mathrm{Cu}$ total estava associado com óxidos de Fe mal cristalizados. Esses autores observaram decréscimo no $\mathrm{Cu}$ extraído com oxalato com o aumento na profundidade do solo, acompanhado de um aumento na concentração do metal na fração residual.

Embora a importância da matéria orgânica na retenção de cobre em solos seja realçada em diversas publicações (Hoelgrem et al. 1993; Bibak, 1994), a porcentagem do metal associado à essa fração foi menor do que $1 \%$ nas amostras de terra, com exceção do BM (8 \% do Cu total). Kuo et al. (1983) não encontraram correlação entre teor total de matéria orgânica do solo (MO) e Cu retido nessa fração. Nesse trabalho, os autores observaram variação de 1,2 a 3,9 \% Cu total associado à matéria orgânica em amostras de terra com teor de MO entre 0,4 e 10,6 \%. A formação de complexos entre 
Solos
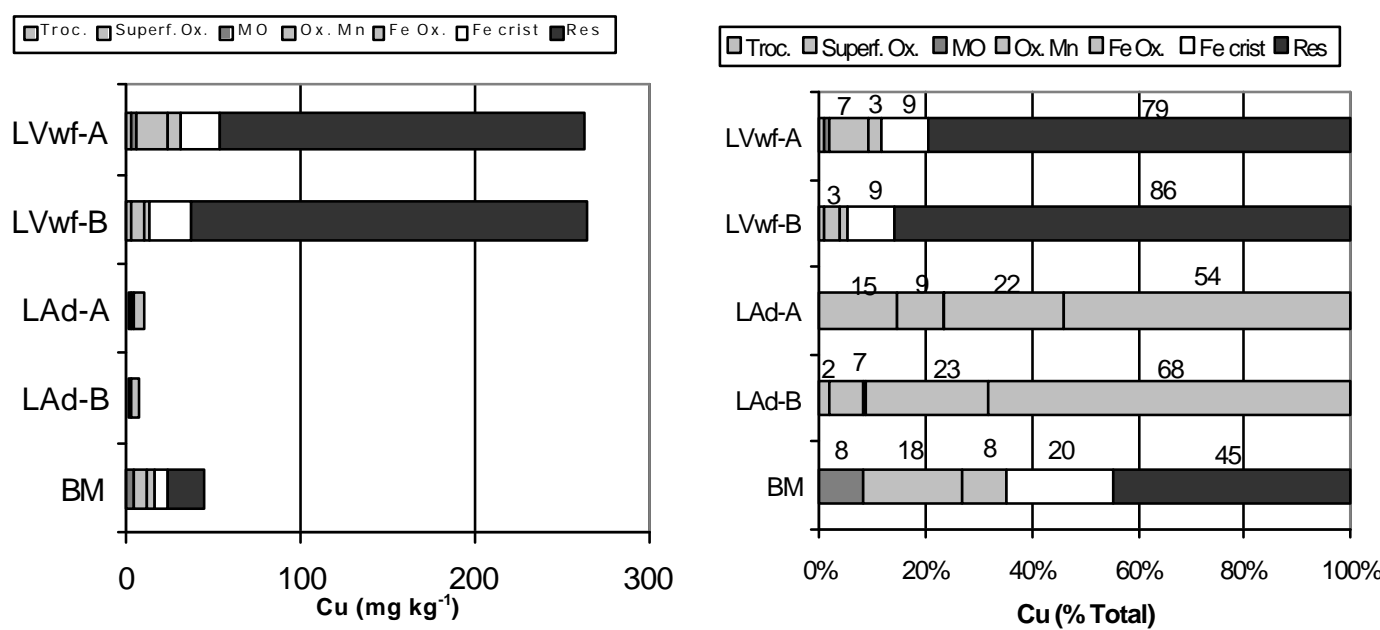

\section{Biossólidos}
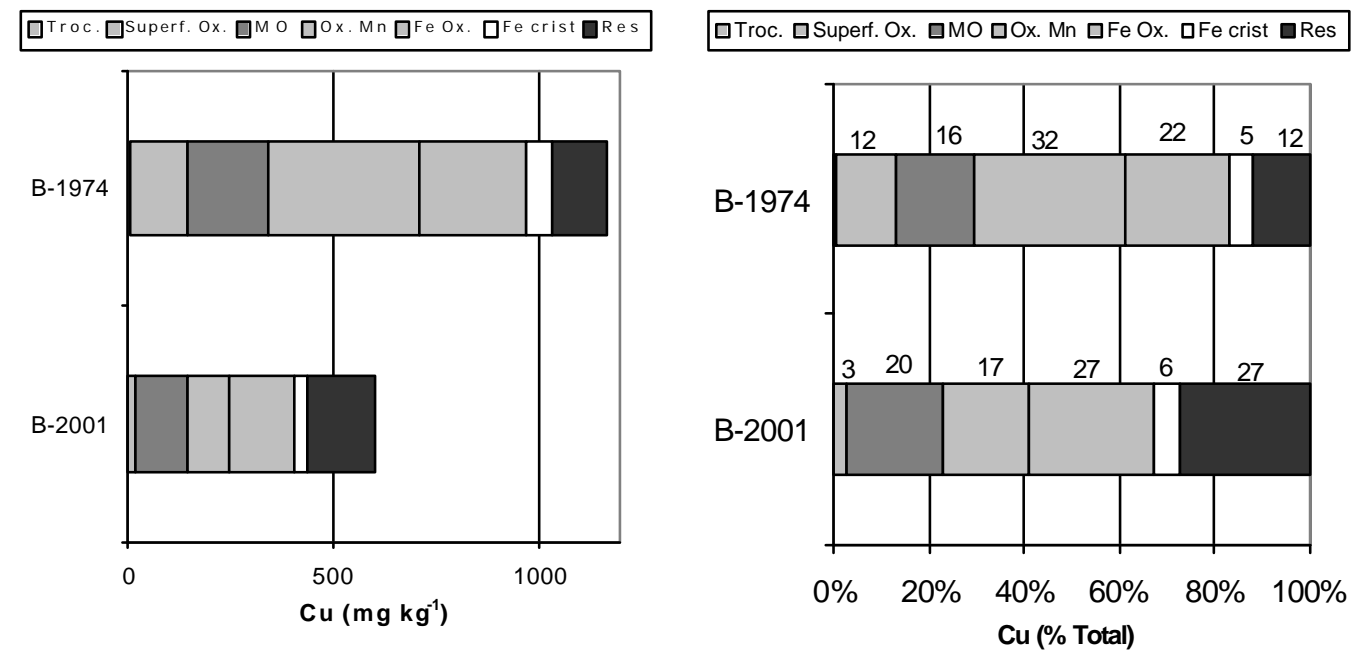

Figura 5 - Fracionamento de $\mathrm{Cu}$ nos solos e nos biossólidos. 
orgânicos com $\mathrm{Cu}$ pode aumentar a mobilidade do metal e favorecer a migração do mesmo no perfil do solo (McBride et al., 1997).

A distribuição de $\mathrm{Cu}$ nos biossólidos foi ligeiramente diferente, porém em ambas as amostras as frações Fe ox e Mn desempenharam papel importante na retenção de $\mathrm{Cu}$ (Figura 5). Para o B-1974, as frações Fe Ox. + Ox. Mn representaram 54 \% do Cu total, enquanto para o B2001, esse valor foi igual a $44 \%$. Os valores de $\mathrm{Cu}$ trocáveis foram iguais a zero em ambos biossólidos. Dentre outros fatores, as características dos biossólidos controlam a taxa de liberação de $\mathrm{Cu}$ para o solo. Por exemplo, Petruzzelli et al. (1994) observaram que para uma amostra de biossólido, aproximadamente 8,5\% do $\mathrm{Cu}$ total estava ligado às frações solúvel e trocável, enquanto para uma segunda amostra, esse valor foi, em média, igual a $42 \%$ do $\mathrm{Cu}$ total. Ambas as amostras eram proveniente da mesma cidade, porém submetidas a diferentes sistemas de tratamento.

\subsubsection{Distribuição de Cd nas frações}

A distribuição de $\mathrm{Cd}$ nos solos seguiu a ordem:

- LVwf-A : Superf. Ox.> MO >Res >Ox.Mn $>$ Fe Ox

- LVwf-B: Superf. Ox. > MO = Res > Ox. Mn > Fe Ox

- LAd-A: Superf. Ox. $>$ MO > Ox.Mn $>$ Fe Ox $=$ Res $=$ Troc.

- LAd-B: Superf. Ox. $>\mathrm{MO}=\mathrm{Ox} . \mathrm{Mn}>\mathrm{Fe} \mathrm{Ox}=\mathrm{Res}$

- BM: MO> Superf. Ox. $>$ Ox. Mn = Res $>$ Fe-Ox

- B-1974: Superf. Ox. $>$ MO $>$ Fe crist $>$ Troc.

- B-2001: Ox. Mn > MO = Superf. Ox .> Fe crist $>$ Troc.

A distribuição de Cd foi semelhante nas amostras, sendo que as frações Surf.Ox. e MO foram as mais importantes na retenção do metal (Figura 6). Cerca de $68 \%$ do $\mathrm{Cd}$ total estava associado à essas frações no LVwf-A, 86 \% no LVwf-B, $82 \%$ no LAd-A, $75 \%$ no LAd-B e $80 \%$ no BM. Esses resultados discordam dos obtidos por Bradley \& Cox (1987), que, estudando sedimentos de rios, encontraram até $70 \%$ do Cd presente na 
Solos
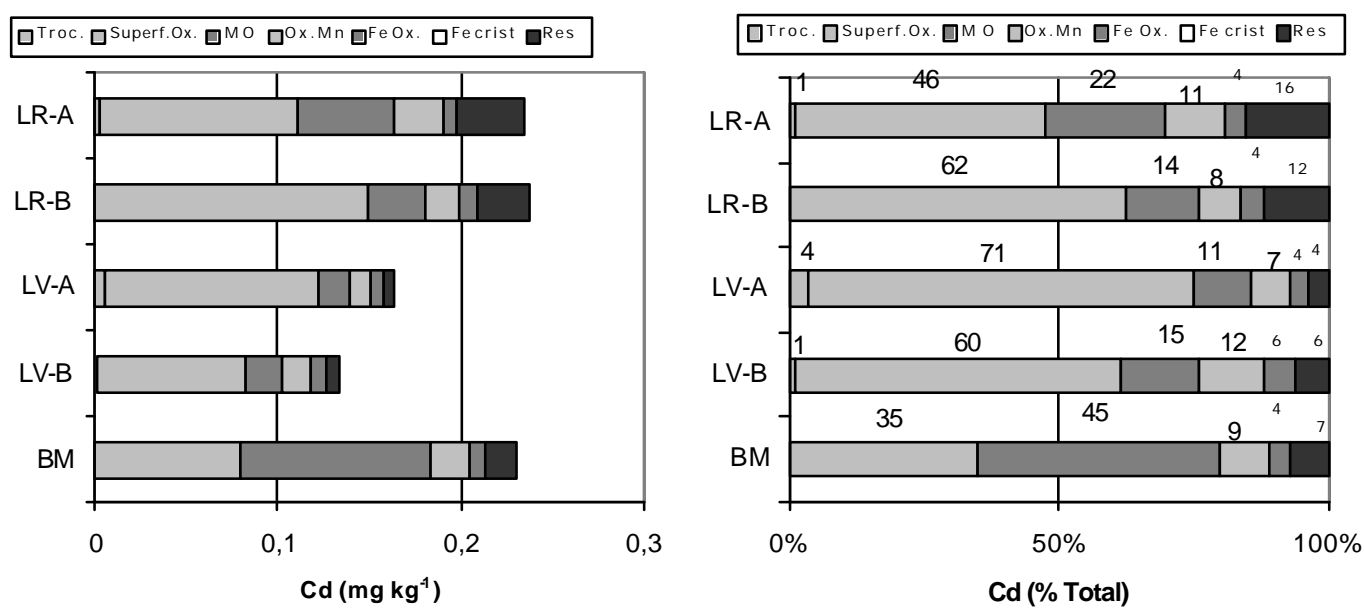

\section{Biossólidos}
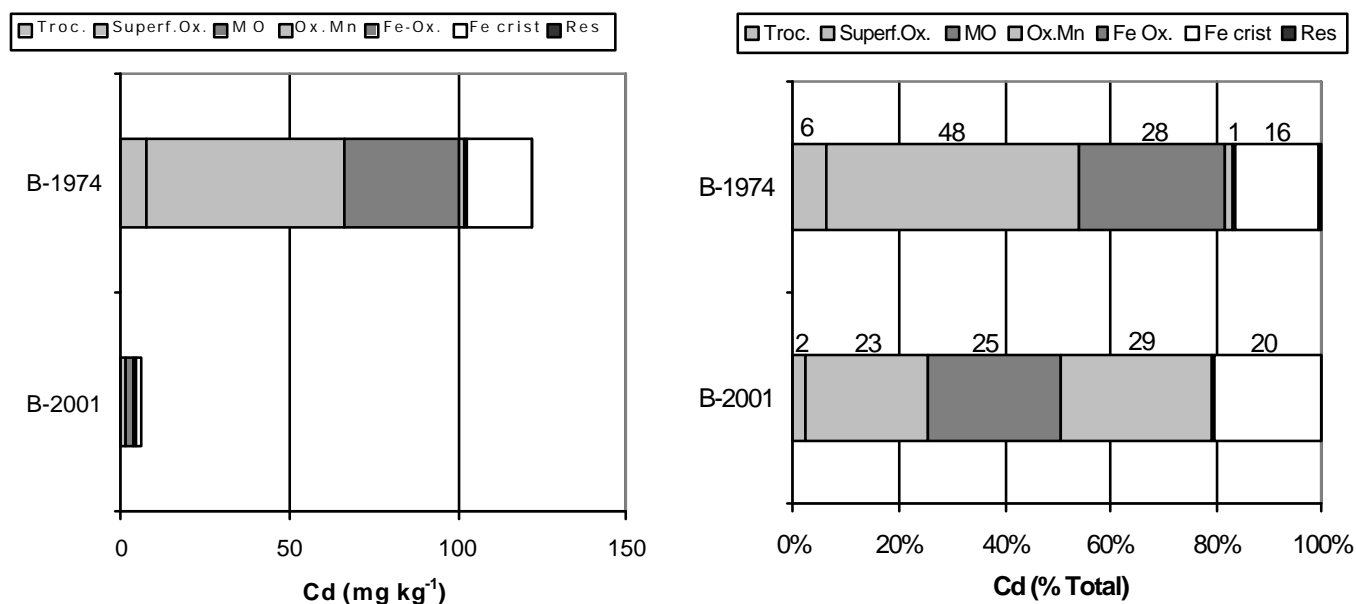

Figura 6 - Fracionamento de Cd nos solos e nos biossólidos. 
fração trocável. Kuo et al. (1983) obtiveram valores entre 30 e $60 \%$ do Cd total na forma trocável. Esses autores, utilizando o mesmo procedimento utilizado no presente trabalho para acessar a fração matéria orgânica, não encontraram $\mathrm{Cd}$ associado a essa fração. Ao contrário, Sastre et al. (2001), utilizando a metodologia de extração de Tessier et al. (1979), encontraram que a maior parte do Cd estava associada à matéria orgânica. No caso específico do fracionamento desenvolvido por Tessier et al. (1979), o procedimento para acessar a fração matéria orgânica utiliza como reagente o $\mathrm{H}_{2} \mathrm{O}_{2}$, que não se mostra ser seletivo aos óxidos de Mn. Portanto, nesse caso, a fração do metal relacionada com a matéria orgânica pode ter sido superestimada.

Embora, o Cd não se encontre em formas prontamente disponíveis nos solos e nos biossólidos, alguns trabalhos consideram as frações extraídas com NaOAc (fração Superf. Ox.) e com $\mathrm{NH}_{2} \mathrm{OH}-\mathrm{HCl}$ (fração $\mathrm{Ox}$. Mn) como potencialmente biodisponíveis (Obrador et al., 1997; Koeckritz et al., 2001). Há relatos de afinidade de Cd por óxidos de Fe cristalinos ou mal cristalizados (Benjamin \& Leckie,1981), mas apenas 4 a 6 \% do

$\mathrm{Cd}$ estava associado com a fração $\mathrm{Fe} \mathrm{Ox}$, e não foi detectado metal ligado à fração $\mathrm{Fe}$ crist. Os óxidos de Fe e Mn apresentam sítios com diferente afinidade a metais e, com exceção do $\mathrm{Pb}$ e $\mathrm{Ag}$, o $\mathrm{Cd}$ apresenta-se como metal com maior afinidade em ser adsorvido por esses óxidos (Benjamin \& Leckie, 1981).

Nos biossólidos a distribuição de $\mathrm{Cd}$ foi ligeiramente diferente (Figura 6). Na amostra B-1974, $76 \%$ do Cd encontroutse associado às frações Superf.Ox.+MO, enquanto no B-2001, o metal estava distribuído em proporções semelhantes entre as frações Ox.Mn, MO, Superf.Ox. e Res.

\subsection{Conclusões}

A extração seqüencial de metais, embora apresente algumas limitações, pode ser utilizada como importante ferramenta em estudos relacionados à geoquímica de metais. $\mathrm{O}$ procedimento deve ser adequado às características físicas e químicas das amostras, a fim de garantir a completa solubilização da fase sólida de interesse. $\mathrm{O}$ esquema proposto mostrou ser adequado para as amostras de terra e biossólidos, com elevados teores de óxidos de Fe. 
Não foi observada variação na distribuição de $\mathrm{Zn}, \mathrm{Cu}$ e $\mathrm{Cd}$ entre os horizontes A e B das amostras de terra. Para os biossólidos, embora os teores de metais tenham sido contrastantes, a distribuição relativa dos mesmos nas frações foi semelhante.

As quantidades de $\mathrm{Zn}, \mathrm{Cu}$ e $\mathrm{Cd}$ associados à fração trocável foram relativamente baixas, indicando que esses metais não se encontram prontamente disponível às plantas nas amostras de terra e de biossólido. $\mathrm{O} \mathrm{Cd}$ foi encontrado, principalmente, ligado à fração superfície dos óxidos/carbonatos, podendo ser facilmente disponibilizado para solução. 


\section{EFEITO DO pH E DA FORÇA IÔNICA NA ESPECIAÇÃO IÔNICA E NA DISTRIBUIÇÃo DE ZINCO, COBRE E CÁDMIO EM AMOSTRAS DE LATOSSOLOS E DE BIOSSÓLIDOS}

\section{Resumo}

A concentração total de metais no solo, embora utilizada como instrumento para monitorar os efeitos da aplicação agrícola de resíduos, tais como os biossólidos, pode não refletir suaa disponiblidade às plantas. Em geral, a disponibilidade desses elementos está relacionada com a distribuição na fase sólida e o equilíbrio das espécies químicas em solução. Os objetivos desse trabalho foram estudar o efeito da aplicação de biossólidos na distribuição de $\mathrm{Zn}, \mathrm{Cu}$ e $\mathrm{Cd}$ nas fases sólida (solo e biossólido) e em solução, e avaliar o efeito da variação do $\mathrm{pH}$ e da força iônica da solução. Foram utilizadas amostras superficiais $(0-20 \mathrm{~cm})$ de dois solos do Estado de São Paulo: Latossolo Vermelho acriférrico (LVwf) e Latossolo Amarelo distrófico (LAd). A amostra de biossólido foi coletada na Estação de Tratamento de Esgoto de Chicago, EUA, em 1974 e apresentou níveis elevados de Zn, Cu e Cd. As amostras de terra foram colocadas para reagir com o biossólido em um aparato experimental designado como câmaras-duplas de difusão. As unidades das câmaras foram preenchidas com solução eletrolítica com força iônica próxima à da solução do solo. No experimento no qual foi testado o efeito da força iônica, esse valor foi aumentado em dez vezes. $\mathrm{O}$ pH da solução foi ajustado para compreender a faixa de 4 a 7. Após o equilíbrio, a solução das câmaras foi centrifugada, filtrada e acidificada para posterior leitura das concentrações dos metais. As amostras de terra e de biossólido provenientes das câmaras foram secas e procedeu-se a extração seqüencial de $\mathrm{Zn}, \mathrm{Cu}$ e $\mathrm{Cd}$. O $\mathrm{Cu}$ foi o metal menos afetado pelas 
variações no $\mathrm{pH}$ do meio, sendo que a maior parte desse elemento permaneceu no biossólido. Ao contrário, as quantidades de $\mathrm{Zn}$ e o $\mathrm{Cd}$ em solução foram aumentadas com a diminuição do $\mathrm{pH}$ devido à maior solubilização do biossólido. Para os três metais, o LVwf exibiu maior capacidade de adsorção em relação ao LAd. No LVwf o Cu e o Zn estiveram associados às frações residual e óxidos de Fe, enquanto no LAd, esses metais foram retidos em frações menos estáveis quimicamente, como a fração superfície dos óxidos. Em ambos os solos, o $\mathrm{Cd}$ estava presente em frações mais facilmente biodisponíveis. Em solução, a maior parte dos metais encontrou-se na forma livre, com exceção do $\mathrm{Cu}$ nos valores mais altos de $\mathrm{pH}$. A redução do $\mathrm{pH}$ aumentou as quantidades dos metais retidos na fração trocável, além de maior atividade dos metais nas formas livre. O efeito da elevação da força iônica não foi marcante quando comparado ao $\mathrm{pH}$. Os resultados apontam para os possíveis riscos ambientais da aplicação de biossólidos, contendo elevados níveis de metais, sobretudo em solos ácidos.

\section{Summary: EFFECT OF pH AND IONIC STRENGHT ON ZINC, COPPER AND CADMIUM SPECIATION AND DISTRIBUTION IN OXISOLS AND BIOSOLIDS}

The total metal concentration is a useful tool to predict the impact of agricultural application of biosolids in soils, but does no reflect their bioavailability. In general, the metal availability is related with its distribution in the solid phase and the chemical equilibrium in solution. The objective of this work was to study the effect of biosolid application in the distribution of $\mathrm{Zn}, \mathrm{Cu}$ and $\mathrm{Cd}$ (in soil and biosolid samples) and their speciation in solution. Surface soil samples $(0-20 \mathrm{~cm})$ from a Rhodic Acrudox (RA) and a Typic Haplorthox (HA) were used. The biosolid, with high heavy metal concentrations, was collected from Sewage Sludge Treatment Facility from Chicago, USA, in 1974. Both soil and sludge were equilibrated in an experimental dual-chamber diffusion apparatus. A background solution with ionic strength similar to that of the soil was added in the chamber to allow he equilibrium between the two phases. The $\mathrm{pH}$ was adjusted to vary in a range from 4 to 7 . In order to study the ionic strength effect, a 
background solution ten times more concentrated than the original soil solution was used. After the equilibrium, the solutions were centrifuged, filtrated, acidified and analyzed. The soil and sludge samples were dried, and the sequential fractionation was performed for $\mathrm{Zn}, \mathrm{Cu}$ and $\mathrm{Cd}$. The $\mathrm{pH}$ had no significant effect on $\mathrm{Cu}$ in comparison with the $\mathrm{Zn}$ and $\mathrm{Cd}$, and most of the metal remained in the biosolid. The concentration of $\mathrm{Zn}$ and $\mathrm{Cd}$ in solution were enhanced with the $\mathrm{pH}$ decrease, due to the higher solubilization of the biosolid. For the three metals, the adsorption capacity was higher in the RA, where $\mathrm{Cu}$ and $\mathrm{Zn}$ were associated with the residual fraction and Fe oxides, while for the HA the metals were related with fractions chemically instable, such as surface oxides. In both soils, $\mathrm{Cd}$ were found in fractions readily bioavailable. Most of the metals were found as free-ions in solution, except $\mathrm{Cu}$ for the higher $\mathrm{pH}$ values. The amount of metal in the exchangeable fraction and the free-metal activity were higher at the lower $\mathrm{pH}$ values. The $\mathrm{pH}$ effect was more evident in the metal distribution than the ionic strength effect. Environmental risks might be associated with the agricultural application of biossolids containing high concentrations of metals, especially in acidic soils.

\subsection{Introdução}

Nos últimos anos, devido ao crescimento urbano e industrial, houve considerável aumento na geração de resíduos. Esses materiais, provenientes de diversas fontes, apresentam caráter poluente quando excedem a capacidade ambiental de acomodação. Diversas estratégias de utilização dos resíduos têm sido propostas pela sociedade e pelas indústrias, ambos setores responsáveis pela maior parte da sua geração. $\mathrm{O}$ uso agrícola de resíduos urbanos e industriais tem se tornado prática comum, ao mesmo tempo que, paralelamente, cresce a preocupação com os riscos desse procedimento.

O lodo de esgoto, também referido como biossólido, é um resíduo derivado das estações de tratamento de esgoto (ETE), gerados diariamente em larga escala. A possibilidade do uso na agricultura desse material consistiu uma das alternativas viáveis para seu gerenciamento, pois permite a reciclagem dos nutrientes. 
Os estudos sobre a utilização agrícola do biossólido são incipientes e, em geral, são desenvolvidos para condições de clima temperado. Nos Estados Unidos tem-se estudado nos últimos 25 anos o impacto do uso do biossólido ra agricultura. De modo geral, o resíduo contribuiu para o crescimento e a produção de várias culturas (Tsadilas

et al., 1995). Contrariamente, há indícios de reduções no desenvolvimento vegetal devido às elevadas concentrações metais, principalmente níquel e zinco (LópezMosquera et al., 2000). Portanto, ao mesmo tempo que o biossólido apresenta efeito benéfico nas práticas agrícolas, sua aplicação contínua e sem critérios pode tornar-se potencialmente arriscada ao meio ambiente.

O biossólido pode apresentar elevados teores de metais pesados, que podem acumular-se no solo, lixiviar para o lençol freático, ou ainda, serem incorporados na cadeia alimentar dos mamíferos. Os metais pesados mais comumente presentes no biossólido, como o chumbo, níquel, cádmio, crômio, cobre e zinco, podem comprometer, a longo prazo, a sustentabilidade do meio ambiente, causando riscos à saúde humana.

\subsubsection{Reações que controlam a disponibilidade de metais no solo}

Os metais pesados, definidos por apresentarem densidade superior a $5 \mathrm{~g} \mathrm{~cm}^{-3}$, têm sua solubilidade controlada por um conjunto de reações químicas que ocorrem no solo. O solo influencia nos ciclos dos elementos traços no ambiente e é considerado um meio controlador da atividade dos mesmos (Kabata-Pendias \& Pendias, 1987). As interações que influenciam a partição do metal nas fases líquida e sólida do solo são responsáveis pela sua mobilidade e biodisponibilidade no sistema (Figura 7)

Os metais, quando adicionados ao solo na forma sólida, tal como nos biossólidos, entram em equilíbrio com a solução do solo e, consequentemente, com a fase sólida. Esse equilíbrio é controlado pelos atributos dos biossólidos e dos solos, pela introdução 


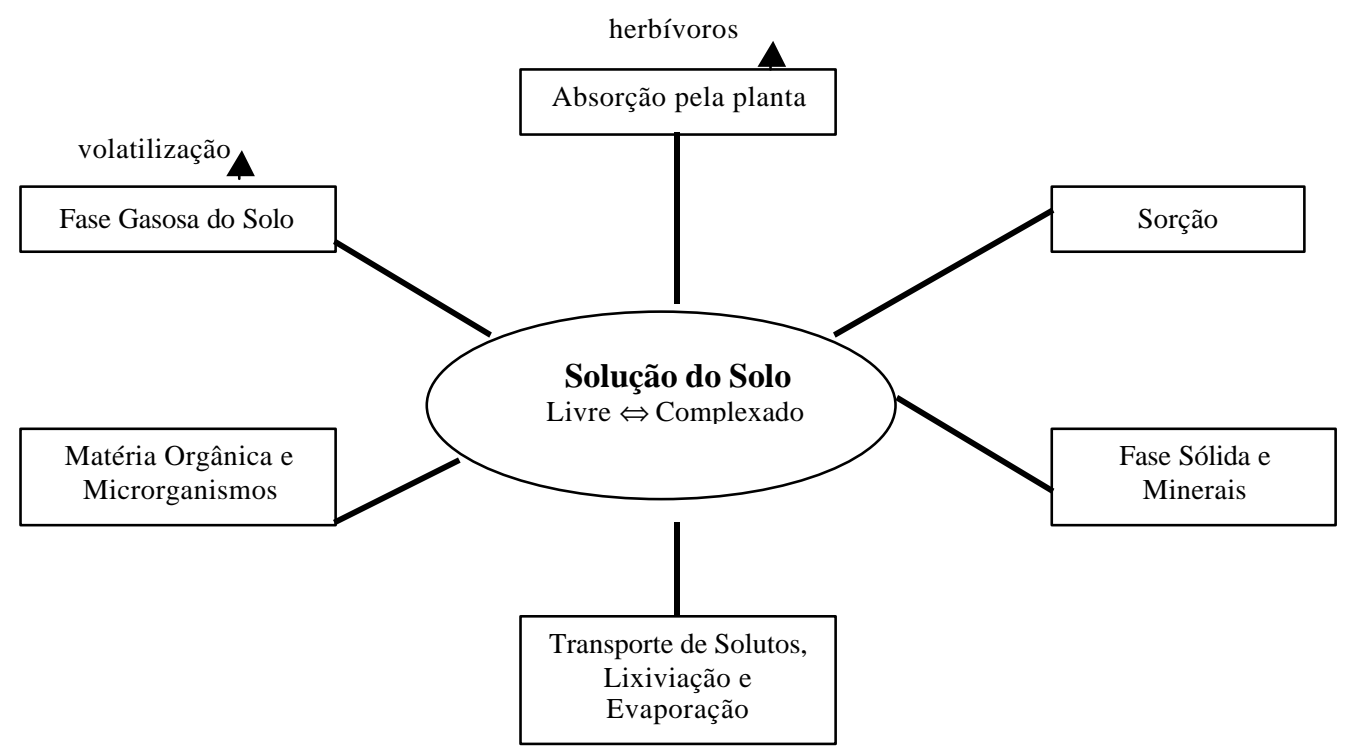

Figura 7 - Dinâmica das reações de equilíbrio de metais nos solos. Adaptada de Lindsay (1979).

de formas químicas do metal e, pela cinética de dissolução do metal (Jing \& Logan, 1992). Nos solos, os óxidos hidratados de $\mathrm{Fe}, \mathrm{Al}$ e $\mathrm{Mn}$, a matéria orgânica e os minerais de argila são considerados os principais componentes que contribuem na retenção dos elementos traços.

Um grande número de fatores influencia a disponibilidade e sorção de metais nos solos, tais como as características dos colóides (minerais de argila, óxidos e matéria orgânica), o pH, a concentração iônica da solução, a presença de cátions e ligantes orgânicos e inorgânicos (Ross, 1994). Esses fatores devem ser considerados, sobretudo, em áreas que recebem tratamento com resíduos contendo metal.

A biodisponibilidade e mobilidade de metais no solo dependem da sua concentração na solução, da natureza da associação com outras espécies iônicas solúveis e da habilidade do solo em fornecê-los para solução do solo em resposta à absorção pelas plantas (Krishnamurti \& Naidu, 2002). Uma vez que não há um consenso sobre um "índice de disponibilidade" que possa ser utilizado como alternativa ao conteúdo total do elemento (Sauvé et al., 2000), a técnica da extração seqüiencial de metais nos solos é uma ferramenta útil para estimar a distribuição de metais na fase sólida. Krishnamurti \& Naidu (2002) destacaram que a extração seqüencial nos diversos 
componentes do solo é importante para prever o potencial do solo em repor metais para solução. Ross (1994) propôs um esquema para explicar a relação entre a extração seqüencial e a disponibilidade de metais às plantas (Figura 8).

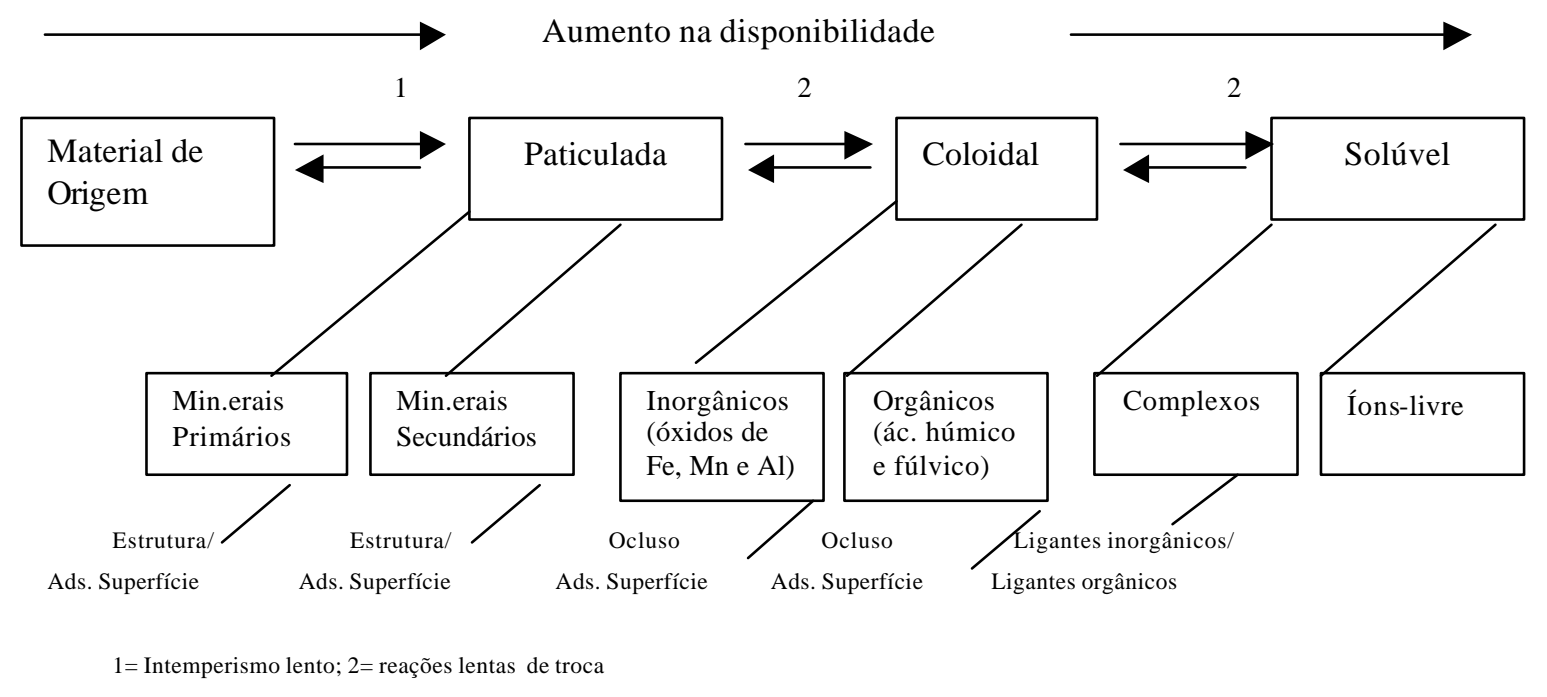

Figura 8 - Formas de metais potencialmente tóxicas nos solos (Adaptada de Ross, 1994).

$\mathrm{O} \mathrm{pH}$ do solo é um dos principais fatores que regula o comportamento e biodisponibilidade de metais pesados (Smith, 1994a, Yin et al., 2002). Em geral, a redução do $\mathrm{pH}$ do solo ocasiona menor adsorção dos metais. Na Comunidade Européia os limites máximos de aplicação de metais via biossólido foram estipulados para uma faixa de $\mathrm{pH}$ entre 6 e 7 e, em solos com $\mathrm{pH}$ mais baixo, o uso de biossólidos é proibido devido ao aumento na disponiblidade dos metais às plantas (Smith, 1994a). Mudanças no pH alteram a distribuição dos metais entre os componentes do solo (Yin et al., 2002). A maior disponibilidade de metais em pHs baixos (meios mais ácidos) que ocorre em solos com carga variável, tais como os Latossolos, é causada pela possibilidade de predominância de cargas positivas no perfil, enquanto em altos valores de $\mathrm{pH}$ a geração de cargas negativas é favorecida. Com a redução do $\mathrm{pH}$, há repulsão entre o colóide e o metal, desfavorecendo as reações de sorção. Porém, a adsorção dos metais pesados não 
depende apenas das cargas elétricas do solo, uma vez que eles podem ser adsorvidos especificamente.

A solubilidade dos metais está diretamente relacionada com sua biodisponibilidade e movimentação no perfil do solo. Em geral, em valores mais baixos de $\mathrm{pH}$, os metais encontram-se em formas móveis; porém elevando-se o pH não haverá, necessariamente, menor solubilidade de metais em solução (Kabata-Pendias \& Pendias, 1987), pois as ligações com complexos orgânicos pode ser favorecida nessa situração. Smith (1994b) observou aumento na concentração de Cd em várias culturas com a diminuição do $\mathrm{pH}$ do solo. Esse autor sugeriu que em meios mais ácidos o $\mathrm{Cd}$ estava presente como metal-livre e, conseqüentemente, pode ser absorvido pela planta. À medida que o $\mathrm{pH}$ foi aumentado, a adsorção de $\mathrm{Cd}$ pelos colóides do solo foi favorecida.

Cada metal apresenta características particulares e pode precipitar e/ou ser adsorvido em condições específicas. Quanto maior o potencial iônico do metal, em geral, maior será o seu grau de hidratação em solução e, conseqüentemente, mais facilmente será precipitado (Tabela 11). Porém, os dados da Tabela 11 foram obtidos em soluções puras e não podem ser extrapolados para solução do solo, principalmente devido aos efeitos da formação de complexos que, por sua vez, interferem na solubilidade dos metais.

Com relação à força iônica da solução, sabe-se que vários cátions em solução podem competir com os metais pesados pelos sítios de adsorção do solo. $\mathrm{O} \mathrm{Ca}^{2+}$, por exemplo, é o cátion mais importante que controla a solubilidade dos elementos traços no solo (Kabata-Pendias \& Pendias, 1987). A composição dos ânions da solução também influencia no comportamento dos metais. Por exemplo, o $\mathrm{Cl}$ parece complexar mais fortemente o $\mathrm{Zn}$ que os demais ânions, resultando no aumento na adsorção desse metal, especialmente em baixos valores de $\mathrm{pH}(4,0-4,5)$ (Shuman, 1986).

\subsubsection{Distribuição dos metais na fase sólida}

Os metais presentes no solo ou nos biossólidos teoricamente podem ser encontrados em diversas frações do solo, representando formas químicas distintas. 
Tabela 11. Propriedades de alguns cátions (Adaptada de Kabata-Pendias \& Pendias, 1987).

\begin{tabular}{|c|c|c|c|c|c|}
\hline & $\begin{array}{c}\mathrm{pH} \\
\text { (precipitação } \\
\text { como hidróxido) }\end{array}$ & Raio Iônico & $\begin{array}{l}\text { Raio iônico } \\
\text { Hidratado }\end{array}$ & Eletronegatividade & $\begin{array}{c}\text { Potencial } \\
\text { Iônico }\end{array}$ \\
\hline & & ----------- & )--------------- & $\mathrm{kcal} / \mathrm{g}$ átomo & Carga/raio \\
\hline $\mathrm{K}^{+}$ & - & $1,7-1,6$ & 3,0 & 0,8 & 0,6 \\
\hline $\mathrm{Na}^{+}$ & - & $1,2-1,1$ & 4,5 & 0,9 & 0,9 \\
\hline $\mathrm{Ca}^{2+}$ & - & $1,2-1,1$ & 6,0 & 1,0 & 1,8 \\
\hline $\mathrm{Mg}^{2+}$ & 10,5 & 0,8 & 8,0 & 1,2 & 2,5 \\
\hline $\mathrm{Fe}^{2+}$ & $5,1-5,5$ & $0,9-0,7$ & 6,0 & 1,8 & 2,6 \\
\hline $\mathrm{Fe}^{3+}$ & $2,2-3,2$ & $0,7-0,6$ & 9,0 & 1,9 & 4,4 \\
\hline $\mathrm{Cu}^{2+}$ & $5,4-6,9$ & 0,8 & 6,0 & 2 & 2,5 \\
\hline $\mathrm{Mn}^{2+}$ & $7,9-9,4$ & $1-0,8$ & 6,0 & 1,5 & 2,0 \\
\hline $\mathrm{Mn}^{4+}$ & - & 0,6 & - & - & 6,5 \\
\hline $\mathrm{Zn}^{2+}$ & $5,2-8,3$ & $0,9-0,7$ & 6,0 & 1,8 & 2,6 \\
\hline $\mathrm{Cd}^{2+}$ & $8,0-9,5$ & 1,03 & - & - & - \\
\hline $\mathrm{Ni}^{2+}$ & $6,7-8,2$ & 0,8 & 6,0 & 1,7 & 2,6 \\
\hline $\mathrm{Cr}^{3+}$ & $4,6-5,6$ & 0,7 & 9,0 & 1,6 & 4,3 \\
\hline $\mathrm{Cr}^{6+}$ & - & 0,4 & - & - & 16,0 \\
\hline $\mathrm{Al}^{3+}$ & $3,8-4,8$ & $0,6-0,5$ & 9,0 & 1,5 & 5,6 \\
\hline
\end{tabular}

Essas frações podem ser definidas empregando-se a metodologia de extração seqüiencial dos sólidos que contém o metal (Shuman, 1991). Para tanto, são utilizados reagentes químicos que, conceitualmente, são capazes de extrair uma fração específica do metal. A distribuição dos metais pesados em frações do solo pode fornecer informações sobre a disponiblidade dos mesmos para as plantas (Sims, 1986). Em geral, são extraídos os metais associados às frações trocáveis, ligados a carbonatos, redutível (oxi-hidróxidos de 
Fe e Mn), oxidáveis (sulfetos e matéria orgânica) e residual (associado ao material de origem) (Forstner, 1993). As frações solúvel e trocável merecem atenção especial, pois são consideradas prontamente disponíveis às plantas. Porém, a concentração do metal associado às frações do solo depende do $\mathrm{pH}$, da força iônica, do potencial redox e dos tipos de cátions e ânions na solução extratora.

A técnica da extração seqüencial de metais é especialmente utilizada para determinar as formas de metais adicionados ao solo via biossólido (Shuman, 1985). Uma das vantagens da extração seqüencial é a possibilidade de avaliar, a longo prazo, a mobilidade dos metais introduzidos no solo e a redistribuição dos mesmos com o tempo. Outra vantagem da técnica é que os efeitos das variações nos atributos dos solos podem ser observados, avaliando as mudanças na distribuição dos metais nas diversas frações (Sim, 1986). Contrariamente, a técnica apresenta algumas desvantagens, tais como a seletividade dos extratores. Além disso, a ocorrência de fenômenos de readsorção e redistribuição dos metais pode se tornar importante (Kheboian \& Beaur, 1987).

\subsubsection{Solução do solo}

A atividade ou concentração efetiva de metais pesados na solução do solo varia consideravelmente dependendo do tipo de solo, do método de extração e do tempo. Por exemplo, Kabata-Pendias \& Pendias (1987), estudando diferentes solos e métodos de obtenção da solução do solo, encontraram concentrações variando de $1-135 \mu \mathrm{g} \mathrm{L}^{-1}$ de $\mathrm{Cu} ; 1-570 \mu \mathrm{g} \mathrm{L} \mathrm{L}^{-1}$ de $\mathrm{Zn}$ e 0,01-300 $\mu \mathrm{g} \mathrm{\textrm {L } ^ { - 1 }}$ de $\mathrm{Cd}$ em solução. Os metais apresentam caráter tóxico e são passíveis de serem absorvidos pelas plantas e animais, quando os mesmos encontram-se na solução do solo. Uma típica solução do solo pode conter trinta diferentes metais e ligantes em concentrações significantes e, aproximadamente 300 complexos solúveis (Sposito, 1981).

Os metais pesados podem estar presentes na solução do solo como "íons-livres", formando complexos com ligantes orgânicos e inorgânicos e/ou pode encontrar-se precipitado. Em geral, as espécies livres em solução são mais prontamente 
biodisponíveis, sendo que sua determinação reflete o equilíbrio entre as diferentes espécies químicas do metal em solução.

Diversas metodologias podem ser utilizadas na determinação da atividade de íons livres não complexados nas soluções do solo (Norvell, 1971; Gardiner, 1974; Baker et al., 1977; Fujii et al., 1983; Amacher, 1984, Fitch \& Helmke, 1989; Hirsch \& Bonin, 1990). Para alguns íons, a atividade pode ser calculada utilizando eletrodos seletivos, porém, para a maioria dos elementos a atividade deve ser calculada após a correção da concentração total do elemento, levando em consideração a formação de complexos solúveis.

Candelaria et al. (1995) compararam as determinações da atividade do $\mathrm{Cd}$ utilizando vários métodos e demonstraram que as atividades dos metais em extratos de saturação de solos que receberam a adição de biossólidos podem ser estimadas pelo programa GEOCHEM-PC (Sposito \& Mattigod, 1980; Parker et al., 1995). Esse programa calcula a especiação iônica baseada nas concentrações das espécies químicas solúveis e nas constantes de estabilidade termodinâmicas para as reações de equilíbrio pertinentes (Sposito, 1981). Os dados iniciais exigidos para executar o programa são a concentração total dos metais e ligantes e o pH. Após, estima-se um valor aproximado para força iônica e os valores da constante de estabilidade condicional são calculados pelo GEOCHEM, baseados nas constantes de estabilidade termodinâmica. O programa calcula então a concentração dos "íons-livres" e a força iônica por meio da solução de um conjunto de equações utilizando o método matemático de Newton-Raphson. Expressando o efeito do metal em termos de atividade, pode-se avaliar com maior segurança o comportamento e os efeitos do metal devido às alterações nas propriedades do solo e do biossólido.

\subsubsection{Limites tóxicos para aplicação de biossólidos}

No Brasil, a legislação que controla os limites máximos de metais presentes nos resíduos está em desenvolvimento. Embora diversos grupos multidisciplinares tenham tentado desenvolver uma legislação própria, atualmente segue-se a legislação vigente 
nos Estados Unidos. Nesse país, a Agência de Proteção Ambiental (USEPA) controla as regulamentações de uso e disposição de biossólidos, por meio de uma série de normas, conhecidas como EPA 503 (USEPA Clean Water Act 503 Regulations) (Estados Unidos, 1993). A falta de critérios científicos tornou-a sujeita a inúmeras críticas. Uma das principais críticas a EPA 503 é que a mesma foi baseada em ensaios de curta duração e em relações empíricas. Nesse sentido, os riscos do uso do biossólido foram calculados, baseados no destino dos poluentes e na população exposta a esses elementos (Estados Unidos, 1993). Definiram-se então os limites nos quais os biossólidos podem ser dispostos ou utilizados beneficamente. Os limites superiores definidos para os metais pesados $(\mathrm{Cd}, \mathrm{Cu}, \mathrm{Hg}, \mathrm{Ni}, \mathrm{Pb}$ e $\mathrm{Zn}$ ) e para elementos não-metálicos (As e $\mathrm{Se}$ ) encontramse 10 a 100 vezes superiores aos encontrados em solos naturais.

Os limites de aplicação de biossólidos formulados pela USEPA foram definidos considerando-se que os metais potencialmente tóxicos estão mantidos em formas químicas não disponíveis para as plantas e em quantidades não nocivas aos consumidores (Ryan \& Chaney, 1994). Acredita-se que a concentração de metais no tecido vegetal nas plantas cultivadas em solos que receberam a adição de biossólidos atinge um limite máximo, à medida que se aumenta sua quantidade no solo (Corey et al., 1987; Chaney \& Ryan, 1992; Estados Unidos, 1993). Esse conceito, também designado como "teoria do platô", recebeu diversas críticas, dentre elas a de que a capacidade de adsorção do solo é favorecida com o aumento no conteúdo de matéria orgânica fornecido pelo biossólido, porém tende a ser minimizada com o tempo após a aplicação. Paralelamente, desenvolveu-se a hipótese da "bomba relógio", na qual acredita-se que a mineralização lenta da matéria orgânica presente no biossólido pode disponibilizar os metais em formas mais solúveis (McBride, 1995). Baseado nessa última teoria, a capacidade dos solos em imobilizar os metais por meio de reações de adsorção e precipitação é limitada e finita. Dessa forma, à medida que o efeito protetor do material adsorvente presente no biossólido seja diminuído, a concentração de equilíbrio do metal eleva-se rapidamente, aumentando sua disponibilidade para as plantas. Esse fenômeno segue o comportamento de uma isoterma de adsorção de Langmuir, sendo que, quanto 
mais próxima à concentração do metal em relação à adsorção máxima do solo, maior o efeito da mineralização da fração orgânica do biossólido.

Neste contexto, conclusões definitivas sobre as vantagens e riscos da utilização agrícola dos biossólidos ainda seriam precipitadas. Aliado a isso, deve-se salientar a natureza distinta dos solos da região tropical, em relação aos solos de clima temperado. A mineralogia essencialmente oxídica presente nos solos muito intemperizados confere características distintas daquelas dos solos com argilominerais do tipo 2:1, influenciando nas reações que controlam a disponibilidade de metais no sistema. Deve-se considerar a importância dos óxidos nas reações de adsorção/dessorção, precipitação e complexação dos metais no solo. Espera-se que, nessas condições, os efeitos da utilização de biossólidos apresentem comportamento diferenciado, sobretudo com relação aos níveis máximos tolerados de metais pesados, sendo, portanto, difícil à adoção direta de uma legislação baseada em critérios desenvolvidos condições diferenciadas.

Os principais objetivos do trabalho foram: a) estudar o comportamento de zinco, cobre e cádmio em solos do Estado de São Paulo com atributos químicos, físicos e mineralógicos distintos, após a adição de biossólido; b) avaliar o efeito do $\mathrm{pH}$ e da força iônica do solo na disponibilidade dos metais e; c) realizar a extração seqüencial no solo e no biossólido, além da especiação iônica dos metais Zn, $\mathrm{Cu}$ e Cd.

\subsection{Material e Métodos}

Foram utilizadas amostras superficiais $(0-20 \mathrm{~cm})$ de dois solos do Estado de São Paulo: Latossolo Vermelho acriférrico (LVwf) e Latossolo Amarelo distrófico (LAd). Os solos apresentam granulometria distintas, o que permite avaliar o efeito da textura, sobretudo do conteúdo de argila, no comportamento dos metais. As amostras foram coletadas na profundidade de $0-20 \mathrm{~cm}$, com objetivo de representar as condições nas quais o biossólido é incorporado ao solo através de práticas agrícolas.

Após a coleta, as amostras foram secas ao ar, moídas em mortar de ágata e peneiradas em peneiras de 100 mesh. Os solos foram caracterizados conforme metodologia preconizada por Camargo et al. (1986) (Tabela 4). Aproximadamente 0,250 
$\mathrm{g}$ de terra e $0,100 \mathrm{~g}$ de biossólido foram pesados e procedeu-se a digestão completa da amostra em microondas, utilizando o método EPA $3052\left(\mathrm{HNO}_{3}, \mathrm{HF}\right.$ e água deionizada) (Estados Unidos, 1996). No caso da amostra de biossólido, antes da adição do ácido nítrico, adicionou-se $1 \mathrm{~mL}$ de $\mathrm{H}_{2} \mathrm{O}_{2} 30 \%$ para solubilizar o material orgânico. A concentração de metais nas amostras de terra e de biossólido está apresentado na Tabela 12.

Tabela 12. Concentração total de $\mathrm{Zn}, \mathrm{Cu}$ e $\mathrm{Cd}$ nas amostras

\begin{tabular}{lccc}
\hline Solo/Biossólido & $\mathrm{Zn}$ & $\mathrm{Cu}$ & $\mathrm{Cd}$ \\
\hline & --184 & 257 & 0,22 \\
LVwf* & 18 & 13 & 0,15 \\
LAd** & 13 & 1263 & 152 \\
Biossólido & 4319 & Acriférrico; **LAd $=$ & Latossolo Amarelo
\end{tabular}
distrófico.

\subsubsection{Aparato Experimental}

Utilizou-se o aparato experimental designado como câmaras-duplas de difusão (CDD), modificado de De Pinto (1982), na qual cada unidade é separada por uma membrana seletiva (Figuras 9 e 10). Em uma das unidades da câmara é adicionada a amostra de terra e, na outra, o biossólido. Ambas as unidades são preenchidas com solução eletrolítica, próxima à força iônica da solução do solo, e um sistema de agitação possibilita que as fases permaneçam em suspensão. Quando montadas as duas unidades das CDD, o conjunto apresenta aproximadamente $23 \mathrm{~cm}$ de comprimento e um volume de $300 \mathrm{~cm}^{3}$. A membrana que separa as duas unidades apresenta poros de diâmetro 0,45 $\mu \mathrm{m}$ e permite que as fases sólidas, no caso o biossólido e o solo, reajam e entrem em equilíbrio através de difusão da fase líquida (Figura 11). Esse diâmetro da membrana utilizado não permite a passagem de metais ligados à fração coloidal entre as duas 
unidades das câmaras. Os filtros de $0,45 \mu \mathrm{m}$ podem separar a fração solúvel da fração particulada (Ross, 1994).

Há trabalhos relacionados ao comportamento de metais pesados, desenvolvidos na Universidade da Califórnia, mostrando as vantagens da utilização de câmaras de difusão (Candelaria \& Chang 1997; Berton et al., 1998). A utilização dessas câmaras permite avaliar a dinâmica dos metais pesados no sistema solo-biossólido, ou seja, possibilita observar e quantificar as interações entre os diversos metais presentes em cada uma das fases. Pode-se observar, por exemplo, o comportamento de determinado metal presente no biossólido e se o mesmo está sendo disponibilizado do resíduo para a solução, ou ainda, avaliar os efeitos da acidez do solo nas reações de equilíbrio entre as fases solo-biossólido. Em estudos conduzidos em câmaras-duplas de difusão, observouse aumento na solubilidade de zinco, níquel, cobre, cádmio, crômio e chumbo com a redução no pH do solo (Berton et al., 1998). Contudo, a determinação dos teores totais dos metais pode não refletir diretamente sua biodisponibilidade (McBride, 1995). Assim, faz-se necessário avaliar a distribuição química nas quais os metais estão adsorvidos na fração sólida, além da sua especiação na solução do solo.

\subsubsection{Atividade química de metais em solos tratados com biossólidos}

No laboratório, as amostras de terra foram colocadas nas CDD para reagir com o biossólido, coletado na Estação de Tratamento de Esgoto de Chicago. Deve-se ressaltar que o biossólido foi coletado em 1974 e apresentou elevados teores de metais, uma vez que a legislação que controla os limites máximos de metais nos biossólidos (EPA 503) não estava implementada nessa época nos Estados Unidos. Essa amostra de biossólido foi escolhida por essa razão, ou seja, os teores elevados de metais, o que permitiu, posteriormente, a leitura e quantificação dos mesmos nos extratos obtidos na extração seqüencial. Após a coleta em 1974, o biossólido foi seco, moído e peneirado a $2 \mathrm{~mm}$ e

armazenado em embalagens fechadas em local seco e sem variações bruscas de temperatura. 


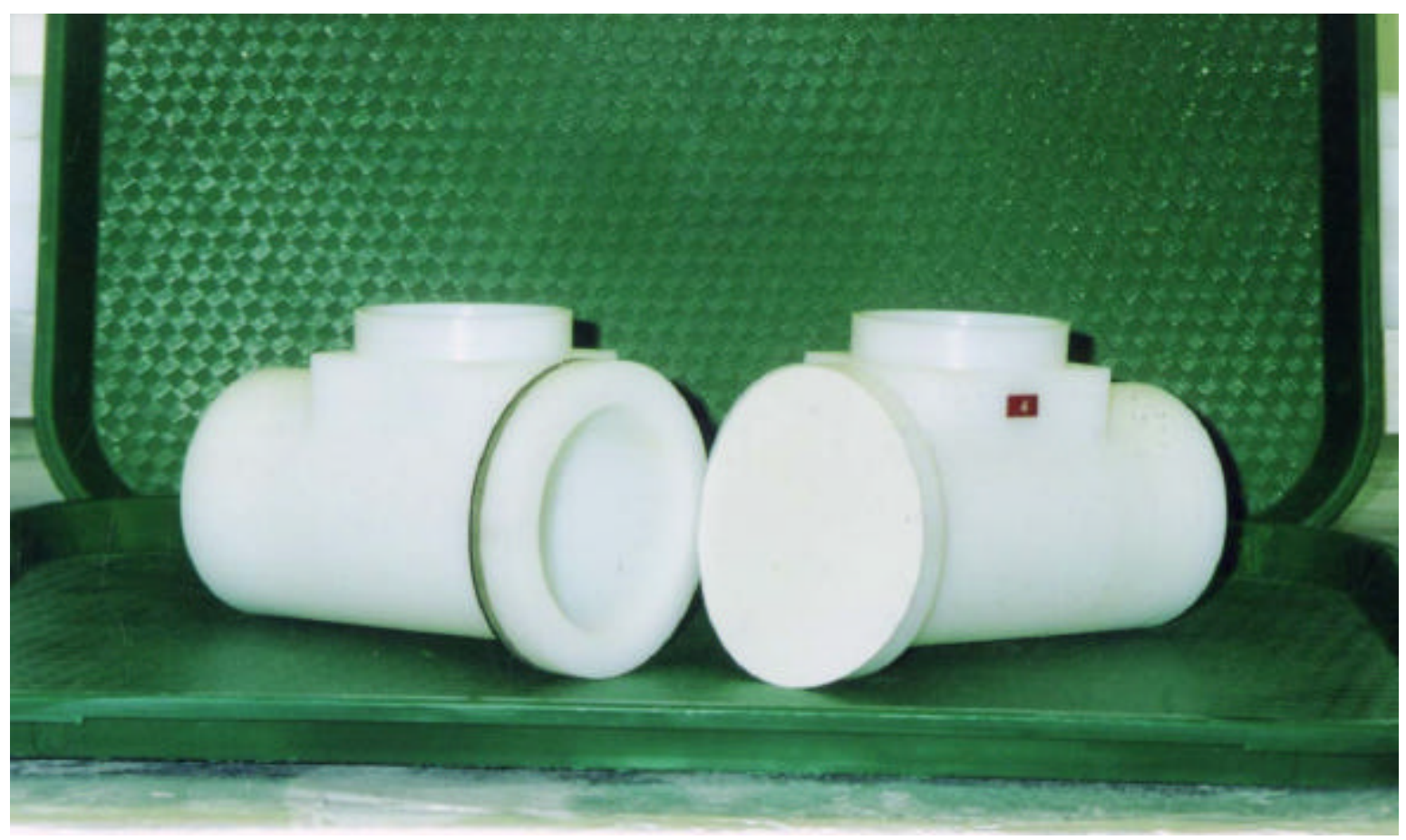

Figura 9 - Unidades das câmaras-duplas de difusão e membrana semi-permeável

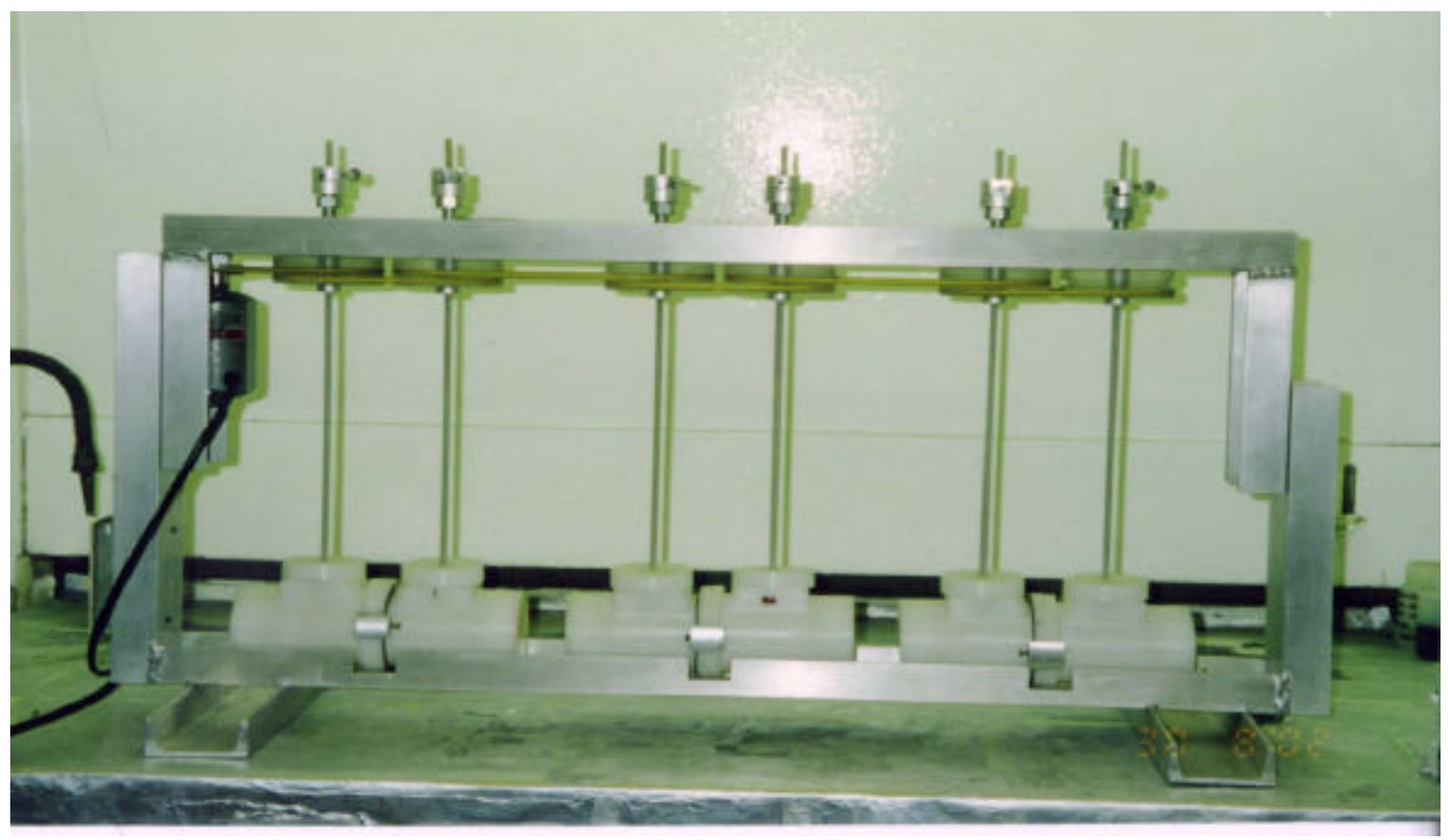

Figura 10 - Conjunto de câmaras-duplas de difusão e sistema de rotação. 


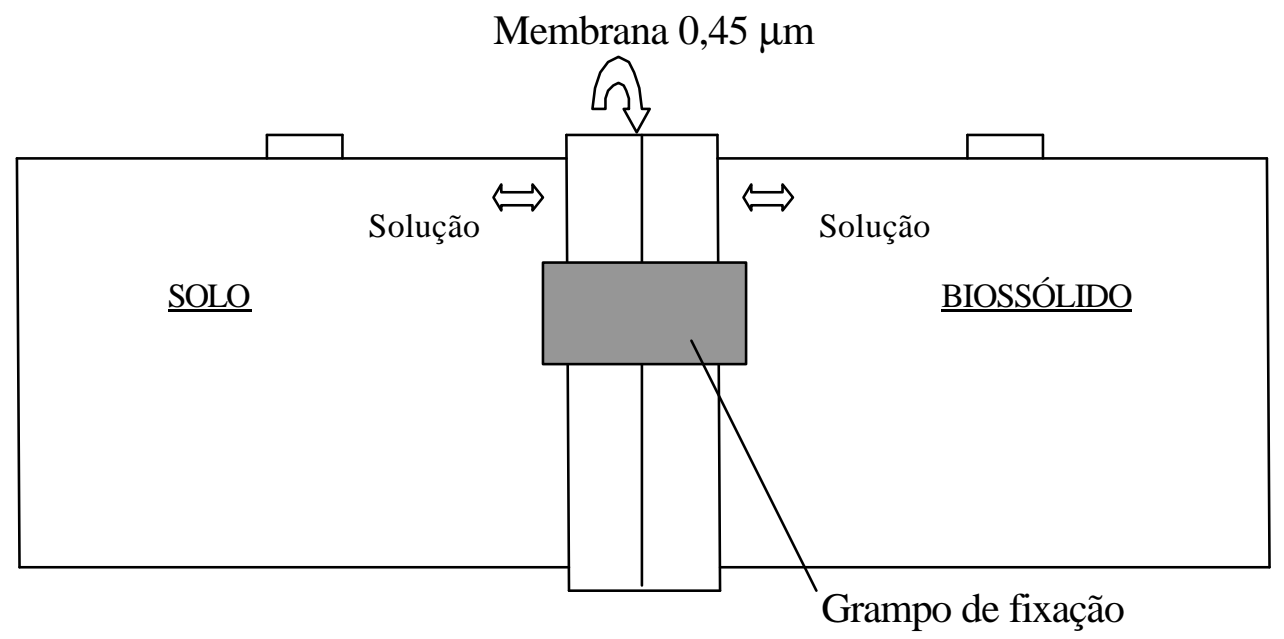

Figura 11 - Representação esquemática das câmaras-duplas de difusão (CDD)

O equivalente a dois gramas de solo e de biossólido foram colocados em cada uma das unidades das câmaras. As câmaras foram preenchidas com solução eletrolítica de $\mathrm{Ca}\left(\mathrm{NO}_{3}\right)_{2}\left(0,005 \mathrm{~mol} \mathrm{~L}^{-1}\right)+\mathrm{CaSO}_{4}\left(0,003 \mathrm{~mol} \mathrm{~L}^{-1}\right)$. A força iônica da solução eletrolítica foi semelhante à da solução do solo, calculada com base nos resultados do extrato de saturação das amostras de terra. $\mathrm{O}$ cálcio foi escolhido por ser o cátion predominante no complexo de troca dos solos, e os ânions nitrato e sulfato porque além de estarem presentes em maior concentração na solução do solo, apresentam menor afinidade em complexar metais e não são considerados capazes de formar complexos de esfera interna com a superfície dos colóides (adsorção específica) (Sposito, 1989). Em cada conjunto de câmaras, utilizou-se uma membrana Millipore de 0,45 $\mu \mathrm{m}$ de abertura de poros e $90 \mathrm{~mm}$ de diâmetro. $\mathrm{O}$ diâmetro das membranas que separam as unidades foi escolhido para que não permitisse a passagem de metais ligados à fase coloidal em solução, definida como partículas solúveis de tamanho superior a 0,45 $\mu \mathrm{m}$ (Yin et al., 2002). Através da solução eletrolítica, os metais, na sua forma iônica, poderiam difundir-se de um dos lados da câmara para o outro. Os conteúdos das câmaras foram agitados, com auxílio de agitadores mecânicos . O sistema de agitação possibilitou que o equilíbrio entre ambas as fases fosse atingido mais rapidamente. $O$ equilíbrio foi 
determinado quando o $\mathrm{pH}$ e a condutividade elétrica em ambos os lados das câmaras foram iguais, ou seja, quando as seguintes reações estivessem em equilíbrio entre as fases (Figura 12).

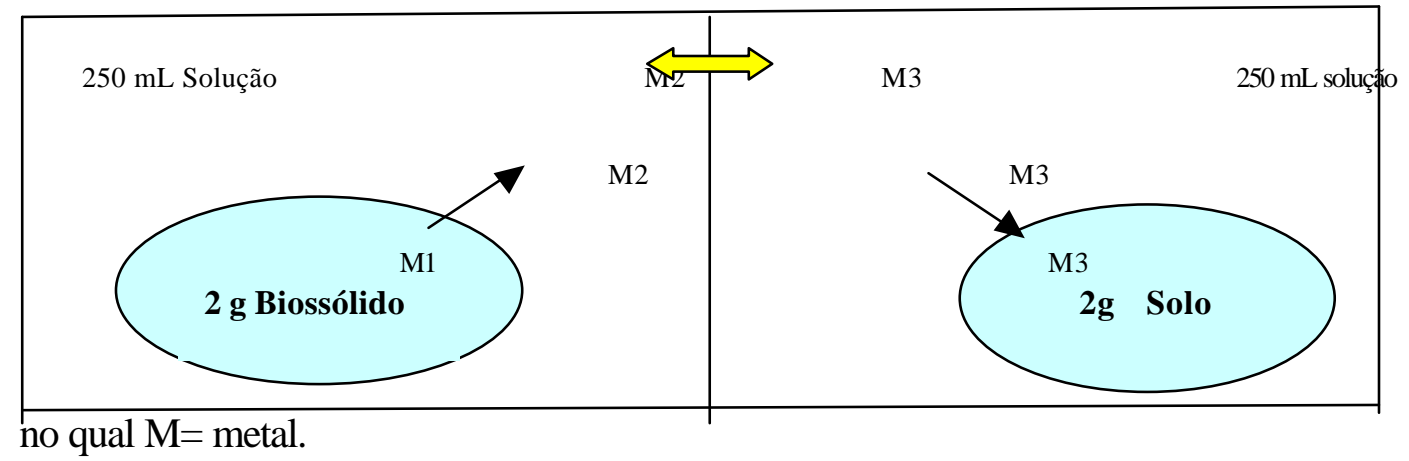

Figura 12 - Reações que ocorrem com os metais nas câmaras

Após o equilíbrio, o solo e o biossólido foram coletados e secos através de congelamento. Parte da solução foi acidificada $\left(1 \% \mathrm{HNO}_{3}\right)$ para evitar o crescimento de microrganismos e, na fração não acidificada, foram analisadas as concentrações dos ânions $\mathrm{SO}_{4}{ }^{2-}, \mathrm{Cl}^{-}, \mathrm{NO}_{3}{ }^{-} \mathrm{e} \mathrm{PO}_{4}{ }^{3-}$, com auxílio de cromatografia de troca iônica. As concentrações dos cátions $\mathrm{Fe}^{2+}, \mathrm{Mn}^{2+}, \mathrm{Zn}^{2+}, \mathrm{Ca}^{2+}, \mathrm{Cu}^{2+}, \mathrm{K}^{+,} \mathrm{Mg}^{2+}, \mathrm{Na}^{+}, \mathrm{Ni}^{2+}, \mathrm{Cd}^{2+}, \mathrm{Pb}^{2+} \mathrm{e}$ $\mathrm{Al}^{3+}$ foram determinadas por espectrometria de absorção e/ou por plasma com espectrômetro de massa acoplado.

A partir das concentrações de cátions e ânions, $\mathrm{pH}$ e carbono orgânico total dissolvido foi calculada a especiação iônica em solução, utilizando o programa GEOCHEM-PC. Foi utilizado o modelo conhecido como "mixture model" (Mattigod \& Sposito et al., 1979) para calcular a interação dos metais com os ligantes orgânicos presentes em solução. Nesse modelo, os ácidos orgânicos que reagem com os metais são caracterizados, incluindo a fração ácido fúlvico presente nos biossólidos (Sposito et al., 1982a). A distribuição quantitativa dos ácidos orgânicos é determinada pela concentração de carbono orgânico na solução. Dentre as vantagens do uso do "mixture model", destaca-se a aplicabilidade em larga faixa de $\mathrm{pH}$ e força iônica (Mattigod \& Sposito et al., 1979). 
A concentração total dos metais nas fases sólidas foi determinada por meio da digestão total da amostras (EPA 3052) (Estados Unidos, 1996). A distribuição desses nas fases sólidas (solo e biossólido) foi calculada utilizando o procedimento de extração seqüencial de metais em suas diversas formas químicas. $O$ balanço de massa foi utilizado para determinar a distribuição dos metais nas fases sólida e líquida, bem como na extração seqüencial. O método da extração seqüiencial consistiu das seguintes etapas:

Pesou-se o equivalente a $1 \mathrm{~g}$ do material seco (solo ou biossólido) e adicionou-se em tubos de centrífuga de policarbonato. Em seguida, procedeu-se a extração seqüencial de $\mathrm{Zn}, \mathrm{Cu}$ e Cd (Tabela 13).

Tabela 13. Esquema de extração seqüencial de metais.

\begin{tabular}{|c|c|c|c|}
\hline Fração & & Reagente & $\begin{array}{l}\text { Tempo de extração/ } \\
\text { Temperatura }\end{array}$ \\
\hline Trocável & Troc. & $15 \mathrm{~mL}$ de $\mathrm{Sr}\left(\mathrm{NO}_{3}\right)_{2} 0,1 \mathrm{~mol} \mathrm{~L}^{-1}$ & $2 \mathrm{~h}, 25^{\circ} \mathrm{C}$ \\
\hline $\begin{array}{l}\text { Adsorvido nas superfícies dos } \\
\text { Óxidos/Carbonatos }\end{array}$ & Superf.Ox. & 15 de $\mathrm{NaOAc} 1,0 \mathrm{~mol} \mathrm{~L}^{-1}(\mathrm{pH} 5)$ & $5 \mathrm{~h}, 25^{\circ} \mathrm{C}$ \\
\hline Matéria Orgânica & MO & $5 \mathrm{~mL}$ de $\mathrm{NaOCl} 5 \%(\mathrm{pH} 8,5)$ & $30 \mathrm{~min}, 90^{\circ} \mathrm{C}$ \\
\hline Óxidos de manganês & Ox.Mn & $\begin{array}{l}50 \mathrm{~mL} \text { de } \mathrm{NH}_{2} \mathrm{OH} . \mathrm{HCl} 0,05 \mathrm{~mol} \mathrm{~L}^{-} \\
{ }^{1}(\mathrm{pH} 2)\end{array}$ & $30 \min , 25^{\circ} \mathrm{C}$ \\
\hline $\begin{array}{l}\text { Óxidos de ferro mal } \\
\text { cristalizados }\end{array}$ & Fe Ox. & $\begin{array}{l}40 \mathrm{~mL} \text { solução oxalato de amônio } \\
0,2 \mathrm{~mol} \mathrm{~L}^{-1}+\text { ácido oxálico } 0,2 \\
\mathrm{~mol} \mathrm{~L}^{-1}(\mathrm{pH} 3,0)\end{array}$ & $\begin{array}{l}2 \mathrm{~h}, \quad \text { agitação } \\
\text { ausência de luz }\end{array}$ \\
\hline Óxidos de ferro cristalinos & Fe crist. & $250 \mathrm{~mL}$ de $\mathrm{HCl} 6 \mathrm{~mol} \mathrm{~L}^{-1}$ & $24 \mathrm{~h}, 25^{\circ} \mathrm{C}$ \\
\hline Residual & Res & $\mathrm{HNO}_{3}+\mathrm{HF}+\mathrm{H}_{2} \mathrm{O}$ & $\begin{array}{l}\text { Digestão } \\
\text { microondas }\end{array}$ \\
\hline $\begin{array}{l}\text { *Entre cada fração, as amostra } \\
\text { papel de filtro Whatmann \#42. } \\
\text { e filtradas para evitar possível } \\
\mathrm{HNO}_{3} \text { com exceção da fração } \mathrm{F} \\
\text { microrganismos. }\end{array}$ & $\begin{array}{l}\text { foram centri } \\
\text { Após, as an } \\
\text { readsorção } \\
\text { e Ox. na Qu }\end{array}$ & $\begin{array}{l}\text { das a } 1225 \mathrm{~g} \text { durante } 10 \mathrm{~min} \text { e o sobrena } \\
\text { cas foram "lavadas" com } 5 \mathrm{~mL} \text { de } \mathrm{NaCl} \\
\text { metais. Os extratos obtidos foram aci } \\
\text { i adicionado } 1 \text { gota de tolueno para ev }\end{array}$ & $\begin{array}{l}\text { adante foi filtrado em } \\
0,1 \mathrm{M} \text {, centrifugadas } \\
\text { dificados a } 1 \% \text { com } \\
\text { itar o crescimento de }\end{array}$ \\
\hline
\end{tabular}


Uma prova do branco foi realizada para cada fração para eventuais correções de determinação. As concentrações de metais ( $\mathrm{Fe}, \mathrm{Mn}, \mathrm{Cu}$ and $\mathrm{Zn}$ ) foram determinadas com auxílio do espectrofotômetro de absorção atômica (chama de ar-acetileno). Os teores de $\mathrm{Cd}$ foram determinados em forno de grafite. $\mathrm{Na}$ determinação de $\mathrm{Cd}$, foram adicionados os seguintes modificadores de matriz: $\mathrm{Mg}\left(\mathrm{NO}_{3}\right)_{2} \quad 0,06 \%$ e $\mathrm{NH}_{4} \mathrm{H}_{2} \mathrm{PO}_{4} 1 \%$ para favorecer o processo de pirólise da amostra.

Para garantir a exatidão das determinações, foram utilizados padrões certificados de água (NIST 1640- Trace elements in Natural Water) para verificar as leituras, além de padrões certificados de solo (NIST 2709- San Joaquin Soil) e biossólido (NIST 2781Domestic Sludge) para avaliar o procedimento de digestão das amostras. O grau de recobrimento, calculado por meio da eq. (5), foi utilizado como critério de controle dos resultados obtidos na extração seqüencial dos metais.

\subsubsection{Efeito da acidez do solo}

Foi estudado o efeito da variação do $\mathrm{pH}$ do solo na disponibilidade de metais do biossólido. Para isso, o $\mathrm{pH}$ da solução eletrolítica foi ajustado lentamente durante o equilíbrio com o biossólido, com auxílio da adição de $\mathrm{HNO}_{3}(1 \%)$ ou $\mathrm{CaCO}_{3}$. A concentração da solução ácida utilizada para promover a redução do $\mathrm{pH}$ foi escolhida, de modo que ñ̃o provocasse alterações drásticas nos valores de $\mathrm{pH}$ e, ainda, não alterasse significativamente a relação solo:solução e a força iônica do meio. $\mathrm{O} \mathrm{CaCO}_{3}$ foi escolhido para elevar o pH da solução baseado em Smith (1994b). Ainda, o $\mathrm{CaCO}_{3}$ não apresenta o inconveniente de algumas bases fortes, tais como o $\mathrm{Ca}(\mathrm{OH})_{2}$ ou $\mathrm{Na}(\mathrm{OH})_{2}$ em

solubilizar a fração matéria orgânica do solo (McBride \& Blasiak, 1979). As quantidades de ácido adicionadas e as variações no $\mathrm{pH}$ foram registradas, bem como os valores de condutividade elétrica. 


\subsubsection{Efeito da variação na força iônica da solução}

As amostras de solo e de biossólido foram equilibradas em duas soluções eletrolíticas nas concentrações de 0,03 e $0,3 \mathrm{~mol} \mathrm{~L}^{-1}$. O valor inferior da força iônica, como citado anteriormente, foi calculado baseado na condutividade elétrica da solução do solo. A concentração superior foi escolhida para avaliar o efeito de uma força iônica da solução do solo dez vezes maior. A precipitação de metais $(\mathrm{M})$ na forma $\mathrm{M}(\mathrm{OH})_{2}$ foi evitada, mantendo-se o pH ao redor de 6 (Shuman, 1986).

\subsection{RESULTADOS E DISCUSSÃO}

\subsubsection{Recuperação de metais nas amostras}

A recuperação de $\mathrm{Cu}, \mathrm{Zn}$ e Cd nas câmaras-duplas de difusão foi entre 81-123 \%, ou seja, um erro ao redor de $\pm 20 \%$ (Tabela 14).

Tabela 14 . Recuperação dos metais nas amostras

\begin{tabular}{|c|c|c|c|c|}
\hline & Tratamento & $\mathrm{Zn}$ & $\mathrm{Cu}$ & $\mathrm{Cd}$ \\
\hline & \multicolumn{4}{|c|}{------------------------------- \% \% ------------------------------ } \\
\hline Câmara 1 & $\mathrm{pH} 7$ & 80 & 85 & 100 \\
\hline \multirow[t]{4}{*}{ (LVwf+biossólido) } & $\mathrm{pH} 6$ & 95 & 101 & 119 \\
\hline & $\mathrm{pH} 5$ & 92 & 104 & 118 \\
\hline & $\mathrm{pH} 4$ & 105 & 104 & 123 \\
\hline & F.I. * & 88 & 95 & 112 \\
\hline \multirow{5}{*}{$\begin{array}{l}\text { Câmara } 2 \\
\text { (LAd+biossólido) }\end{array}$} & $\mathrm{pH} 7$ & 81 & 85 & 107 \\
\hline & $\mathrm{pH} 6$ & 90 & 95 & 113 \\
\hline & pH 5 & 97 & 96 & 114 \\
\hline & $\mathrm{pH} 4$ & 98 & 100 & 118 \\
\hline & F.I.* & 91 & 97 & 122 \\
\hline
\end{tabular}

* F.I.= força iônica 10 vez superior à da solução do solo 
Em todas as amostras, os valores de recuperação de Cd foram superiores a 100 \%. Uma vez que a concentração de $\mathrm{Cd}$ na solução eletrolítica na qual as câmaras foram equilibradas, bem como nos ácidos usados na digestão foi igual a zero, excluiu-se a possibilidade de contaminação das amostras com $\mathrm{Cd}$. Possivelmente, a recuperação de Cd superior a 100 \% nas amostras após o equilíbrio deve-se a erros de diluição das amostras e/ou interferência de algum íon no processo de leitura, uma vez que os resultados de Cd do NIST, em água, atenderam os limites certificados.

\subsubsection{Efeito do pH e da força iônica na distribuição dos metais nas fases sólida e líquida}

Em geral, para valores de $\mathrm{pH}$ entre 6 e 7, a maior parte do $\mathrm{Cu}$, do $\mathrm{Zn}$ e do $\mathrm{Cd}$ ficou retido no biossólido (Figuras 13 a 15). Embora se saiba do efeito da matéria orgânica dissolvida em valores elevados de $\mathrm{pH}$, promovendo a solubilização de metais (Yin et al., 2002), esse efeito não foi observado nas amostras de biossólido estudadas. À medida que o pH foi reduzido, a dissolução do biossólido foi favorecida, resultando maiores quantidades de metais em solução e/ou adsorvidos pelos solos. Com relação ao efeito da força iônica, tratamento denominado (F.I.), não foram observadas mudanças na distribuição dos metais entre as fases sólida e líquida, quando se aumentou a força iônica em dez vezes. O valor de $\mathrm{pH}$ da solução no tratamento F.I. foi ao redor de 6 e os resultados de distribuição dos metais foram semelhantes ao tratamento no mesmo $\mathrm{pH}$, porém com valor de força iônica semelhante ao da solução do solo. Cerca de 81-98 \% do Zn, 86-91 \% do $\mathrm{Cu}$ e 87-89 \% do Cd total permaneceram no biossólido após o equilíbrio no tratamento F.I. A concentração dos metais na solução, em \% do total, no F.I. foi igual a 0,2-0,3 para $\mathrm{Cu}$; 6,5-8,0 para $\mathrm{Zn}$ e 10-11 para $\mathrm{Cd}$. Esses valores em solução foram semelhantes aos encontrados no tratamento a $\mathrm{pH}$ 6, demonstrando que a força ônica aumentada em dez vezes não favoreceu a maior disponibilização dos metais do lodo e/ou maior concentração desses em solução. Nessas condições, a elevação na concentração de sais na solução do solo não favoreceu a elevação dos teores de metais na fase líquida, possivelmente, devido ao $\mathrm{pH}$ elevado do biossólido, ao redor de 7. 

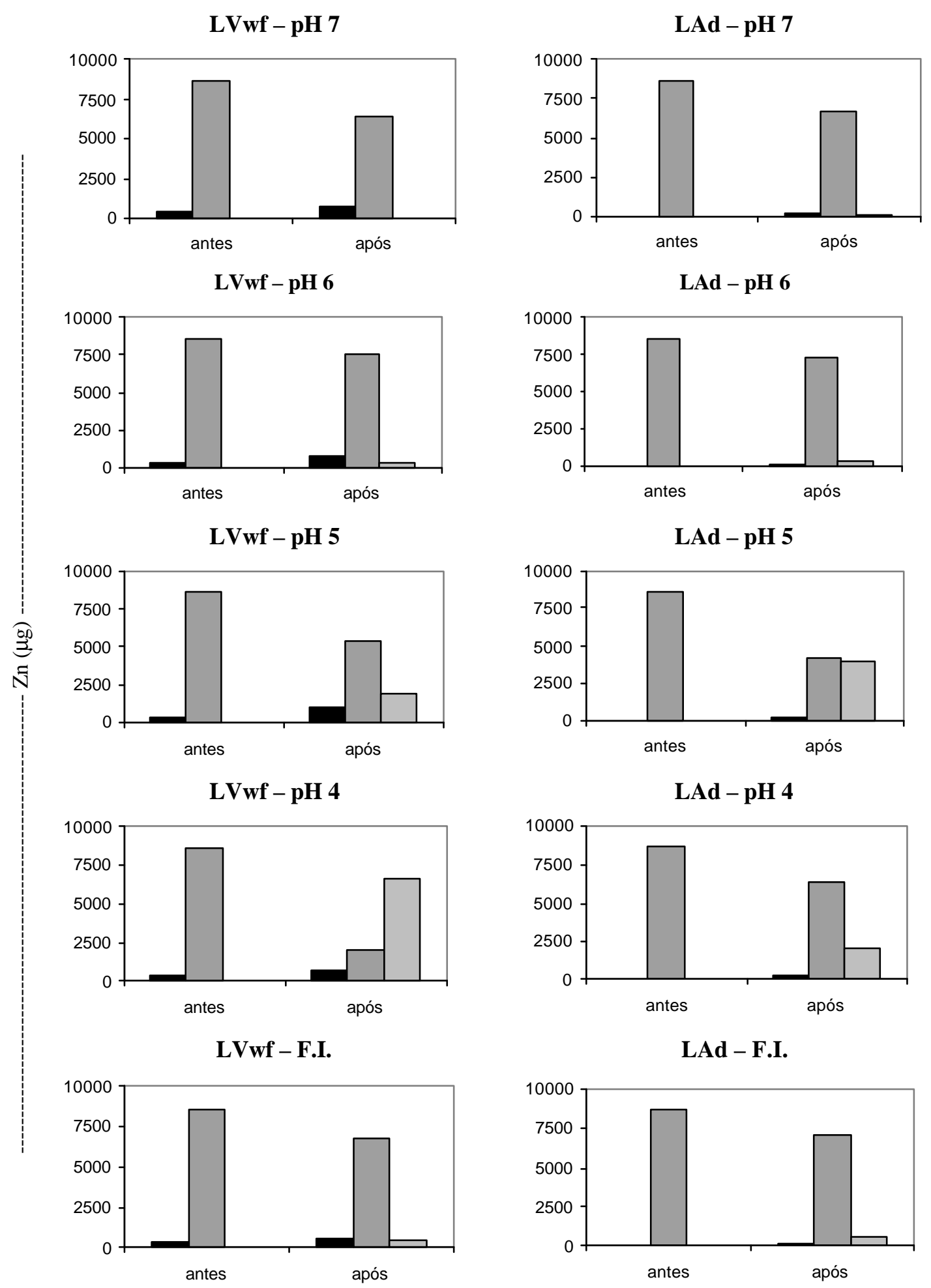

$$
\text { LAd - F.I. }
$$

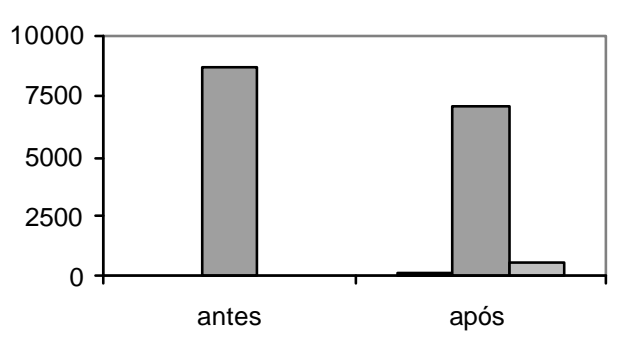

Figura 13 - Distribuição de Zn nas fases sólida (2 g de terra e de biossólido) e líquida (500mL de solução) antes e após o equilíbrio nas câmaras.( $\boldsymbol{\square}_{\text {= Solo }} \square=$ Biossólido $\square$ = Solução). 

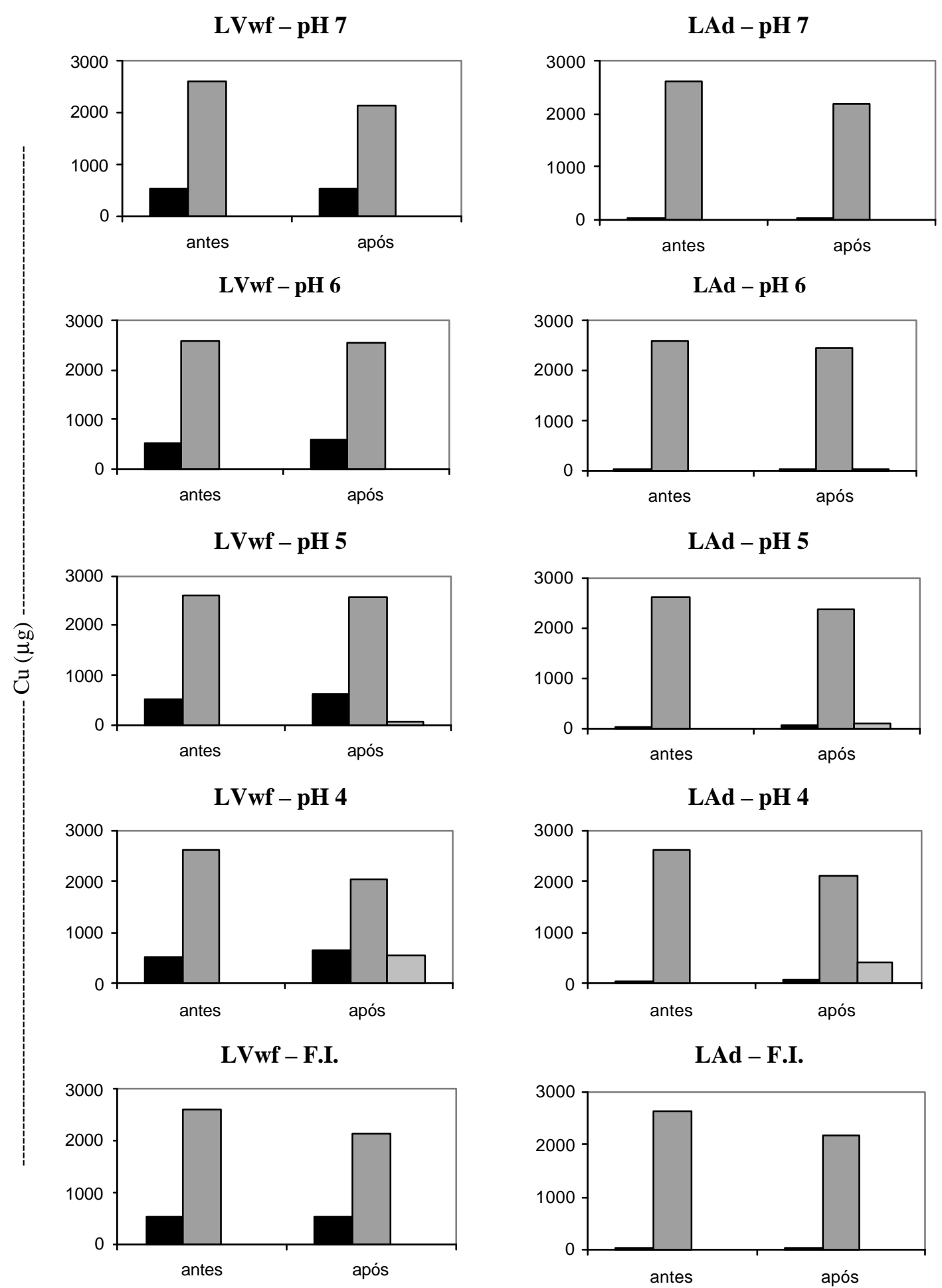

$$
\text { LAd - F.I. }
$$

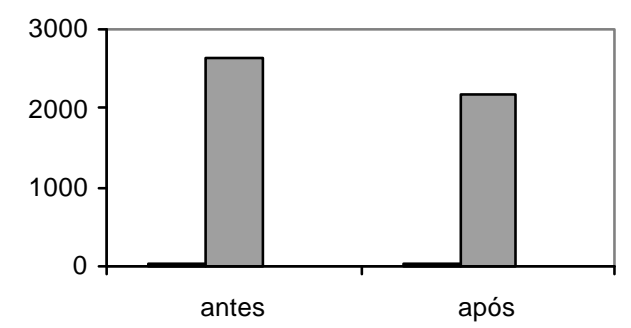

Figura 14 - Distribuição de Cu nas fases sólida (2 g de terra e de biossólido) e líquida (500 mL de solução) antes e após o equilíbrio nas câmaras.( $\square$ = Solo $\square=$ Biossólido $\square$ = Solução). 

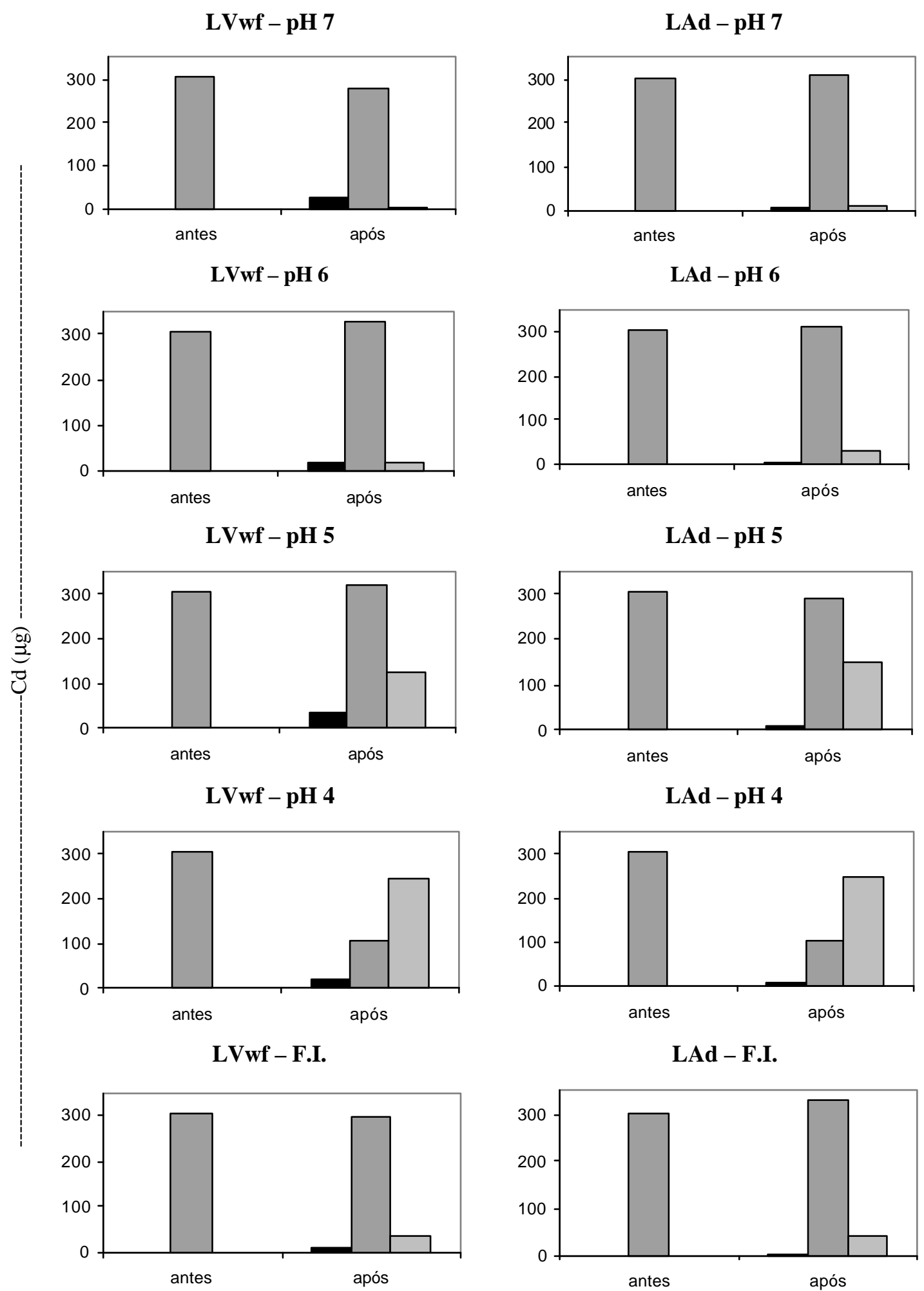

LAd - F.I.

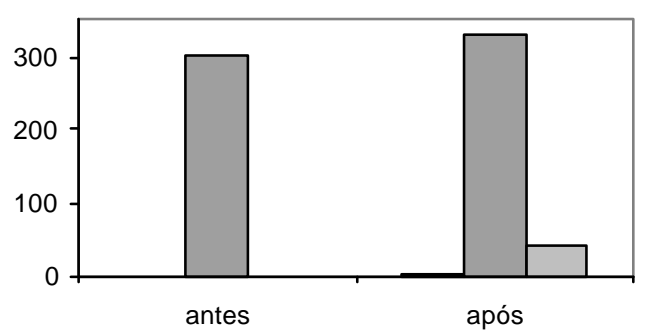

Figura 15 - Distribuição de Cd nas fases sólida (2 g de terra e de biossólido) e líquida (500 mL de solução) antes e após o equilíbrio nas câmaras.( $\square$ = Solo $\square=$ Biossólido $\square$ = Solução). 
Zhu \& Alva (1993) observaram efeito mais acentuado do aumento da força iônica na adsorção de metais, especialmente, em solos com $\mathrm{pHs}$ mais baixos. Esses autores sugerem que os cátions em solução podem competir pelos sítios de adsorção dos colóides, porém esse efeito foi menos acentuado em $\mathrm{pHs}$ acima de 6,6, pois nessas condições os solos apresentaram elevada afinidade em adsorver os metais. Concordando com esses resultados, Fotovat \& Naidu (1998), estudando solos ácidos e alcalinos, observaram que o aumento da força iônica foi diferenciado dependendo do metal e do $\mathrm{pH}$ do solo. Eles observaram que nos solos alcalinos ( $\mathrm{pH}$ entre 7,35 e 8,66), apenas a concentração de $\mathrm{Cd}$ foi aumentada com a elevação da força iônica, acompanhado da diminuição nos teores de $\mathrm{Zn}$ e de $\mathrm{Cu}$ em solução. Petruzzelli et al. (1985) observaram redução no coeficiente de distribuição de metais $\left(\mathrm{K}_{\mathrm{d}}\right)$ com o aumento da força iônica da solução de 0,005 para $0,01 \mathrm{~mol} \mathrm{~L}^{-1}$, porém o $\mathrm{pH}$ dos solos estudados por esses autores variou entre 4,2 e 5,5. Embora sejam escassos os trabalhos que mostrem os efeitos da elevação da força iônica da solução na retenção de metais nos biossólidos, sugere-se que, devido às suas características, sobretudo o $\mathrm{pH}$ elevado e a presença de substâncias recalcitrantes, tais como os óxidos de Fe e Mn, o aumento na concentração de sais na solução não é um fator importante que controla a disponibilização de metais para a solução do solo.

Em todos os tratamentos, conduziu-se um conjunto de câmaras denominado testemunha, na qual não foi adicionado solo, ou seja, o biossólido foi equilibrado apenas com a solução eletrolítica. Em geral, as quantidades dos metais em solução foram superiores nessas câmaras testemunhas, uma vez que não havia a presença do solo para adsorver o metal disponibilizado do biossólido. Esse efeito foi mais acentuado nos valores de $\mathrm{pH}$ mais baixos.

Não foi observado efeito da redução do $\mathrm{pH}$, de 7 para 6 , na solubilização do biossólido. Os valores dos metais retidos no biossólido, nos pHs 6 e 7, foram, em média, iguais a $90 \%$ do total para o Cu, $92 \%$ para o $\mathrm{Zn}$ e $91 \%$ para o $\mathrm{Cd}$. Em geral, a dissolução desses metais foi mais acentuada na amostra de biossólido que foi equilibrada com o LVwf. A quantidade dos metais em solução, após o equilíbrio, foi ao redor de 
0,1-0,9\% do total para $\mathrm{Cu}$; $0,4-5 \%$ para $\mathrm{Zn}$ e $1-8 \%$ para $\mathrm{Cd}$, nos valores de $\mathrm{pH}$ iguais a 6 e 7.

Á medida que o $\mathrm{pH}$ foi reduzido para 5 , as quantidades de $\mathrm{Cu}, \mathrm{Zn} \mathrm{e} \mathrm{Cd}$ solubilizadas do biossólido foram aumentadas, resultando maior concentração dos metais em solução e, consequentemente, maior adsorção desses elementos pelos solos. No $\mathrm{pH} 5,95 \%$ do $\mathrm{Cu}, 50 \%$ do $\mathrm{Zn}$ e $65 \%$ do $\mathrm{Cd}$ permaneceram no biossólido equilibrado com o LAd. Já no biossólido que reagiu com o LVwf, esses valores foram iguais a $79 \%$ para o $\mathrm{Cu}, 64 \%$ para o $\mathrm{Zn}$ e $66 \%$ para o $\mathrm{Cd}$. No $\mathrm{pH}$, as quantidades dos três metais em solução foram maiores na câmara que continha o LAd e relação ao LVwf, que por sua vez, apresentou maior capacidade de adsorção dos metais. Por exemplo, no caso do $\mathrm{Zn}$, nesse valor de $\mathrm{pH}$, o LVwf reteve $13 \%$ do $\mathrm{Zn}$ total, enquanto no LAd esse valor foi igual a $2 \%$ do $\mathrm{Zn}$ total. Essa maior capacidade adsortiva do LVwf deve-se, possivelmente, aos seus maiores conteúdos de argila (Tabela 4) e de óxidos de Fe e Mn (Tabela 5). Sobretudo nos valores mais baixos de $\mathrm{pH}$, as concentrações de $\mathrm{Cd}$ em ambos os solos ( $3 \mathrm{mg} \mathrm{kg}^{-1} \mathrm{Cd}$ no LAd e 12 no LVwf) foram superiores às propostas por Smith (1994b) como limites máximos de $\mathrm{Cd}$ no solo com o intuito de proteger a cadeia alimentar. Esse autor sugeriu que os limites máximos de $\mathrm{Cd}$ no solo em função do $\mathrm{pH}$ deveriam ser iguais a 2,0; 2,5 e $3 \mathrm{mg} \mathrm{kg}^{-1}$ do metal em pHs variando entre 5,0; 5,5-6,0 e $>7,0$, respectivamente. Porém, os teores de $\mathrm{Cd}$ nas amostras de solo após o equilíbrio com o biossólido foram inferiores ao limite máximo desse metal estipulado pela EPA503 (85 mg kg-1 Cd) (Estados Unidos, 1993). Tomando como base os limites máximos no solo de metais encontrados por Smith (1994a), os teores de $\mathrm{Cu}$ e $\mathrm{Zn}$ no LVwf (pHs 4 e 5) encontram-se acima desses valores, porém bastante inferiores aos limites determinados pela EPA-503 (Estados Unidos, 1993).

No pH mais baixo, ou seja, igual a 4, a solubilização dos metais do biossólido foi ainda mais favorecida. Cerca de $81 \%$ do $\mathrm{Cu}$ total, $23 \%$ do $\mathrm{Zn}$ e $30 \%$ do $\mathrm{Cd}$ ficaram retidos no biossólido equilibrado com o LAd,. Para o biossólido equilibrado com o LVwf, aproximadamente $63 \%$ do $\mathrm{Cu}, 21 \%$ do $\mathrm{Zn}$ e $29 \%$ do Cd total ficaram retidos no resíduo. Com a redução de apenas uma unidade de pH (5 para 4), as quantidades dos metais retidos no biossólido diminuíram de $87 \%$ para $72 \%$ no caso do $\mathrm{Cu}$, de 57 para 
$22 \%$ para o $\mathrm{Zn}$ e de 65 para $30 \%$ para o $\mathrm{Cd}$. Em contrapartida, as quantidades de metais adsorvidos pelos solos não foram aumentadas em resposta à maior concentração de metais em solução no pH 4. Em geral, o LAd adsorveu aproximadamente $2 \%$ do total dos metais presentes no sistema, tanto em $\mathrm{pH} 4$ como em $\mathrm{pH}$ 5. O LVwf adsorveu aproximadamente $20 \%$ do $\mathrm{Cu}, 8 \%$ do $\mathrm{Zn}$ e $6 \%$ do $\mathrm{Cd}$ total. Esse comportamento resultou em maiores quantidades de metais em solução no pH 4. Quando se comparam os resultados obtidos nos pHs 5 e 4, o aumento na quantidade de metais em solução foi da ordem de $14 \%$ para o $\mathrm{Cu}, 38 \%$ para o $\mathrm{Zn}$ e $37 \%$ para o $\mathrm{Cd}$.

Esses dados sugerem que o $\mathrm{pH}$ tem efeito diferenciado, dependendo do metal estudado. $\mathrm{O} \mathrm{Cu}$ proveniente do biossólido teve sua disponibilidade afetada de forma menos intensa quando comparado ao $\mathrm{Zn}$ e ao $\mathrm{Cd}$. Mesmo no $\mathrm{pH}$ mais baixo, cerca de 63-81 \% do $\mathrm{Cu}$ permaneceu no biossólido após o equilíbrio. Com relação aos demais metais, no $\mathrm{pH} 7$, o biossólido apresentava aproximadamente $93 \%$ do $\mathrm{Zn}$ e do $\mathrm{Cd}$ total, porém, esses valores foram iguais a 22 e $30 \%$ em $\mathrm{pH} 4$ para $\mathrm{Zn}$ e $\mathrm{Cd}$, respectivamente. Sugere-se nos biossólidos, assim como nos solos, a afinidade em reter $\mathrm{Cu}$ seja superior em relação aos demais metais estudados. Esses resultados concordam com os obtidos por Smith (1994a). Esse autor, estudando solos o efeito do $\mathrm{pH}$ em solos tratados com biossólidos, não encontrou aumento na concentração de $\mathrm{Cu}$ no tecido foliar em função da acidez do solo. Porém, paralelamente, os teores de $\mathrm{Zn}$ e $\mathrm{Ni}$ foram aumentados significativamente a ponto de causar toxidez às plantas. A conclusão desse trabalho foi que o $\mathrm{Cu}$ era retido mais fortemente na superfície do solo em relação aos demais metais. Yin et al. (2002) citaram que a quantidade de $\mathrm{Cu}$ solúvel no solo estava relacionada ao conteúdo total do metal, independentemente do $\mathrm{pH}$. Entretanto, a quantidade de íonslivre era afetada por ambos os fatores, ou seja, $\mathrm{pH}$ e $\mathrm{Cu}$ total.

\subsubsection{Distribuição de Zn nas amostras}

As quantidades de $\mathrm{Zn}$ adsorvidas nos solos foram bastante semelhantes na faixa de pH 4 a 7 (Figuras 16 e 17). No LVwf, a adsorção de Zn foi reduzida com o pH da solução, com exceção do pH 5, que apresentou a maior adsorção do metal. 


\section{LVwf}
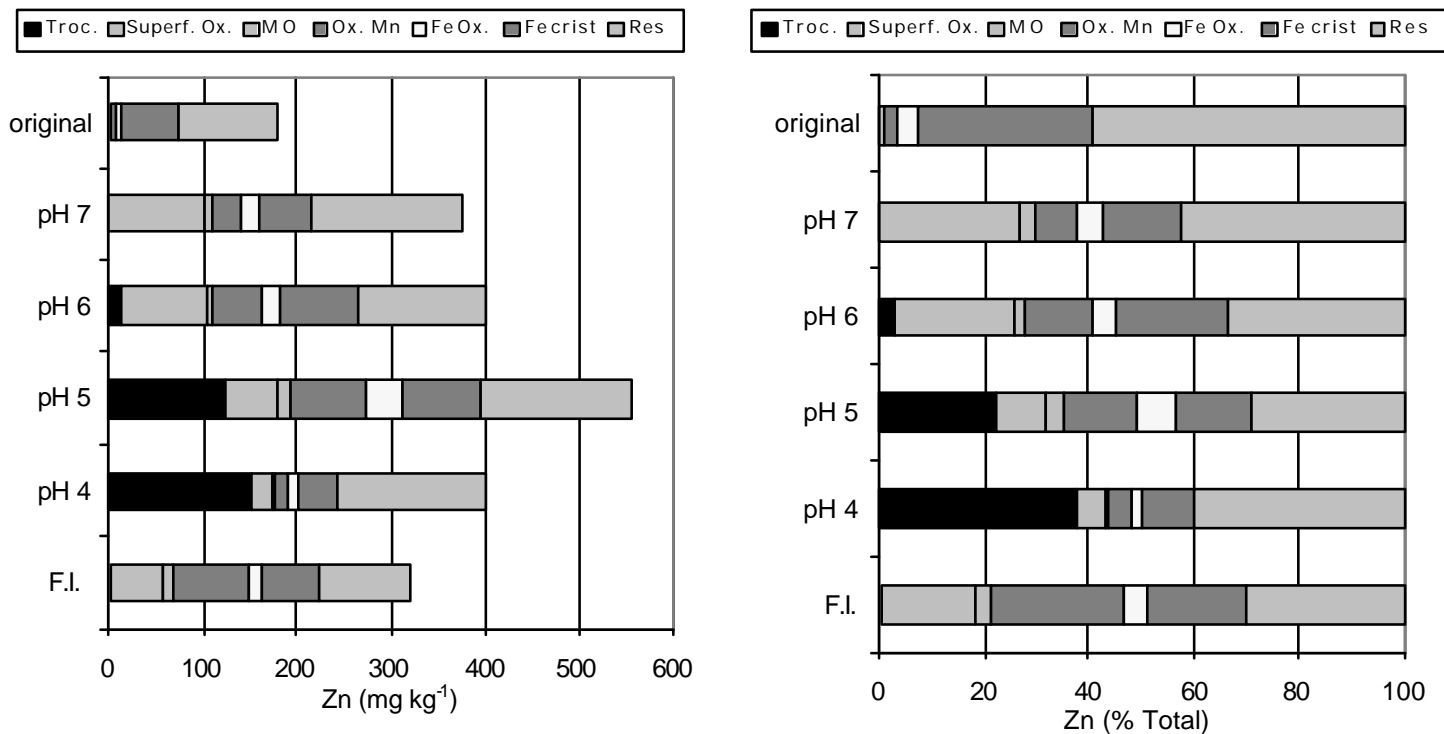

\section{LAd}
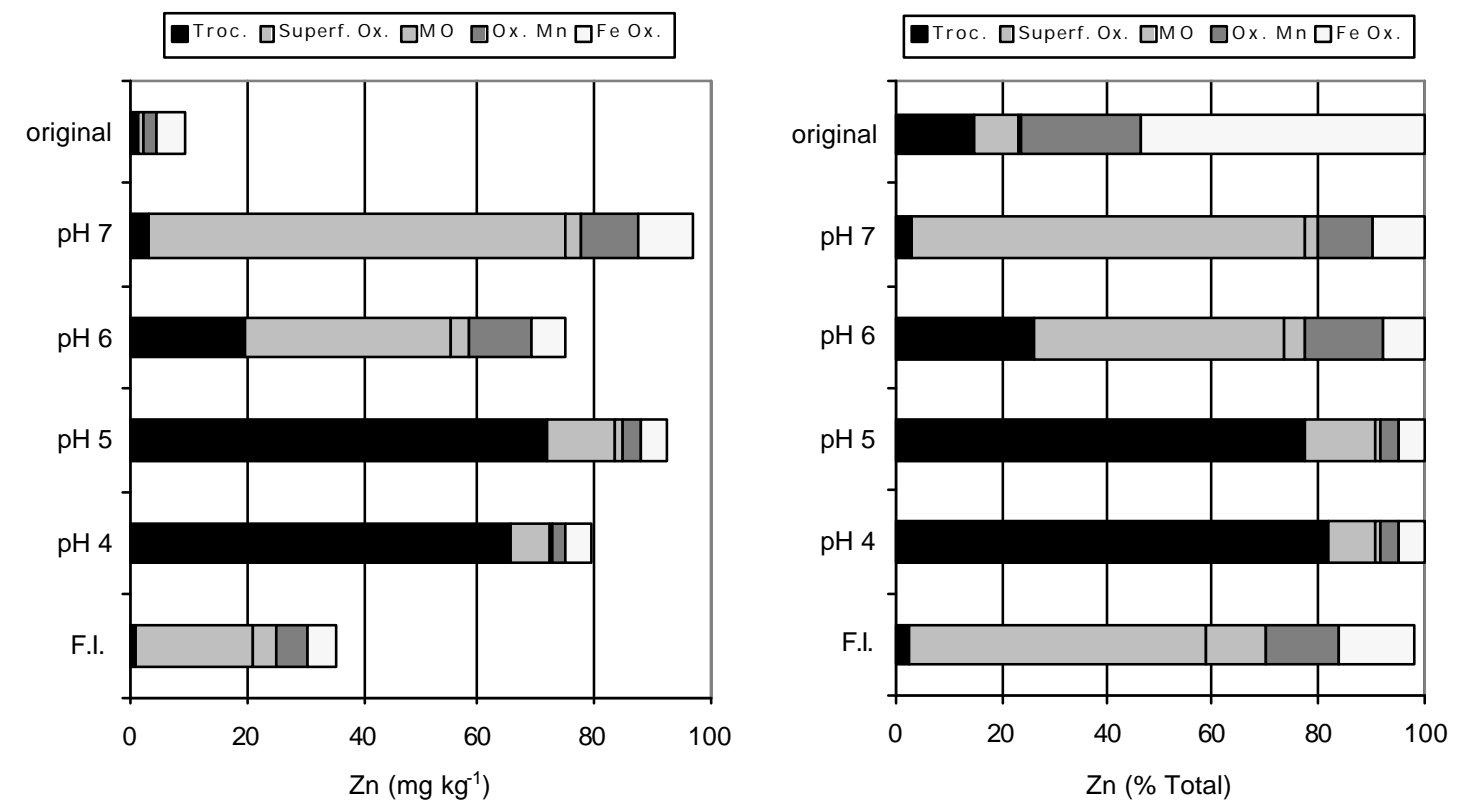

Figura 16 - Extração seqüencial de Zn nas amostras de terra após o equilíbrio nas câmaras. 
Biossólido 1*
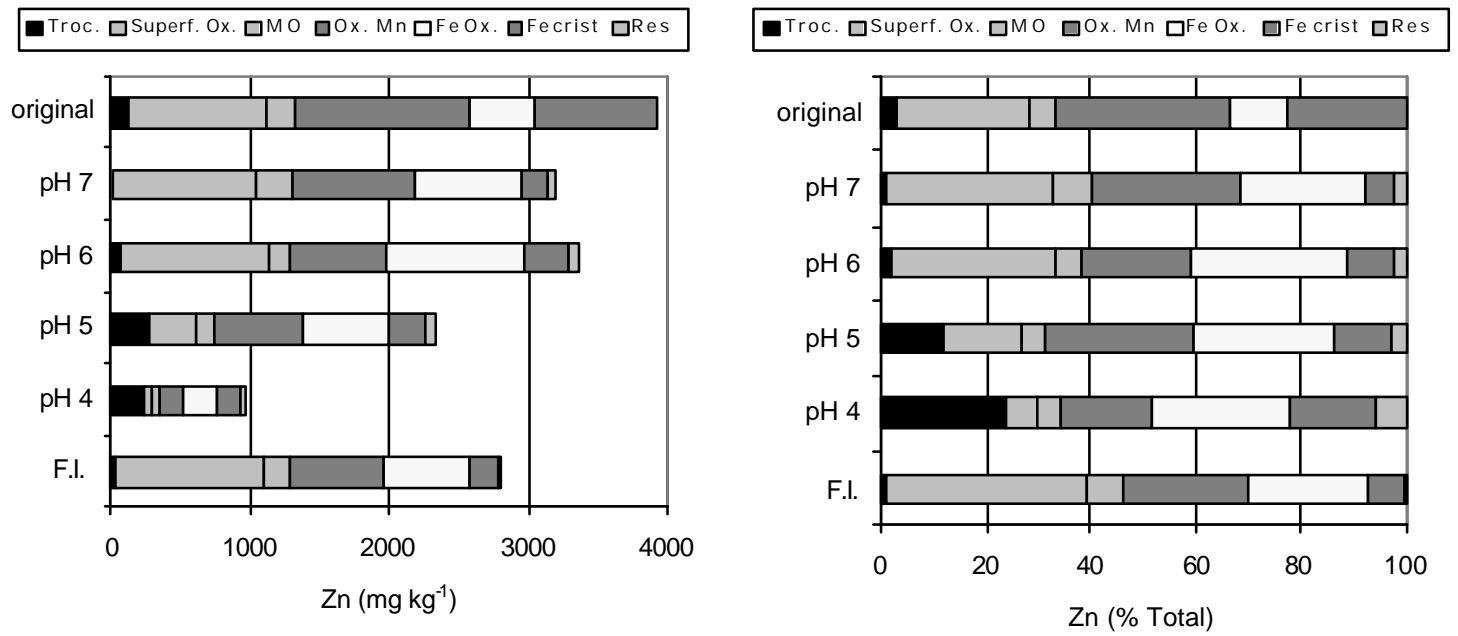

Biossólido 2**
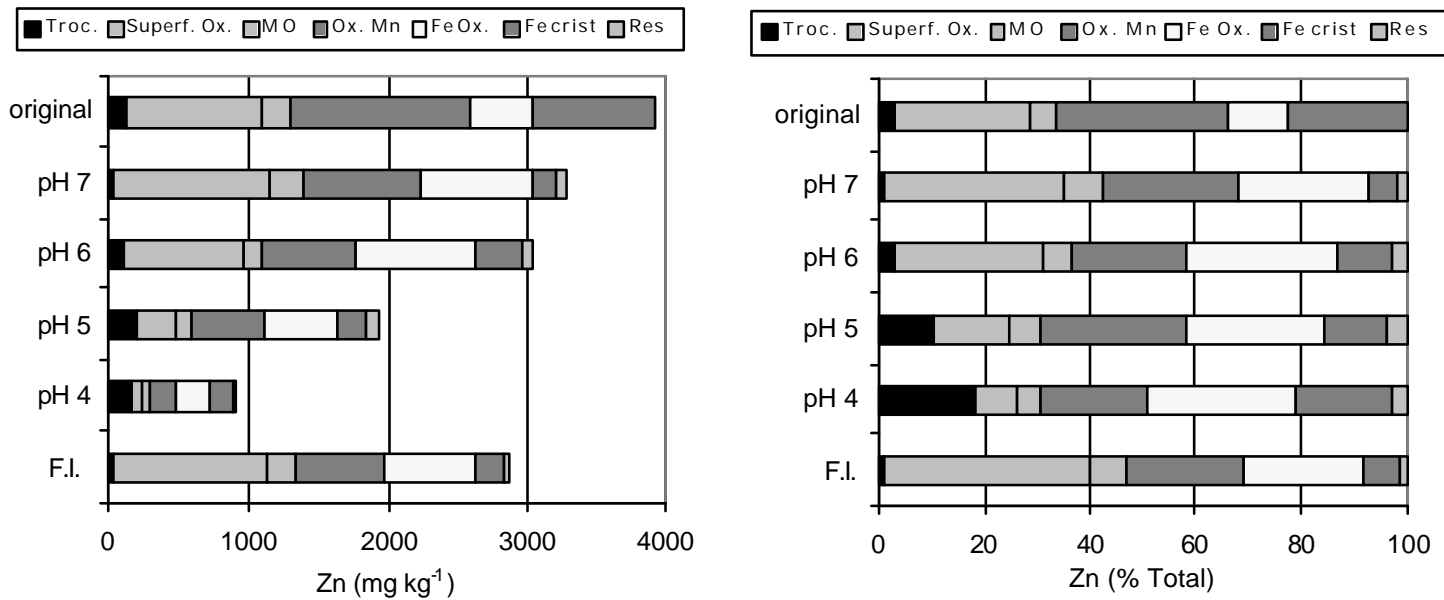

Figura 17 - Extração seqüencial de Zn nas amostras de biossólido após o equilíbrio nas câmaras. *Biossólido $1=$ equilibrado com o LVwf; **Biossólido 2= equilibrado com o LAd. 
Em contrapartida, as quantidades de $\mathrm{Zn}$ retidas no biossólido foram reduzidas com o aumento da acidez, devido à sua solubilização em solução. No LAd, ao pH 7 observouse maior adsorção do metal e, contrariamente, no $\mathrm{pH} 6$ houve a menor quantidade de $\mathrm{Zn}$ adsorvido nesse solo. Isso evidencia a maior solubilização de metais do biossólido em valores de $\mathrm{pH}$ mais baixos. As diferenças no efeito do $\mathrm{pH}$ na adsorção de $\mathrm{Zn}$ em ambos os solos deve-se às características dos solos, resultando em diferentes afinidades em adsorver o metal e, sobretudo, à taxa de dissolução e disponibilização dos metais do biossólido.

Para ambos os solos, os óxidos de $\mathrm{Fe}$ e $\mathrm{Mn}$ foram os principais componentes responsáveis pela retenção de $\mathrm{Zn}$ (Figura 16). Além deles, o pH e os minerais de argila também influenciam a solubilidade de $\mathrm{Zn}$ nos solos (Abd-Elfattah \& Wada, 1981). Especialmente em valores de $\mathrm{pH}$ elevados, o $\mathrm{Zn}$ apresenta baixa solubilidade e alta afinidade em ser adsorvido, sobretudo, pelos óxidos dos solos (McBride \& Blasiak, 1979). Em solos ricos em matéria orgânica, a complexação de Zn por ligantes orgânicos em pHs elevados é favorecida, reduzindo a oclusão ou precipitação do metal nos óxidos de Fe e Mn. Porém, os valores de $\mathrm{Zn}$ associados à fração MO variaram entre 0 a 4,6 \% do $\mathrm{Zn}$ total em ambos os solos, possivelmente, devido aos baixos teores de matéria orgânica dos solos. McBride \& Blasiak (1979) sugeriram que na faixa de $\mathrm{pH}$ entre 5,5 a 7,0 a solubilidade do $\mathrm{Zn}$ não é controlada pela formação de complexos orgânicos entre o metal e o solo.

$\mathrm{Na}$ amostra original do LVwf, aproximadamente $93 \%$ do $\mathrm{Zn}$ total estava associado às frações Fe crist e Res (Figura 16). Isso se deve à mineralogia desse solo, representada principalmente pelos óxidos e por minerais de argila do tipo 1:1 (caulinita) e ao maior conteúdo de argila desse solo em relação ao LAd (Tabela 4). O Zn associado à fração residual pode estar ligado à estrutura dos minerais de argila. Nessas condições, o metal não se encontra disponível às plantas a menos que o processo de intemperismo o disponibilize para solução (Akhter, 1990). A acentuada afinidade do $\mathrm{Zn}$ pelas frações $\mathrm{Fe}$ crist. e Res corrobora os resultados obtidos por Abd-Elfattah \& Wada (1981), que encontraram que 38 a $100 \%$ do $\mathrm{Zn}$ total associado aos minerais de argila e hidróxidos de Fe e Al. Shuman (1979) também concluiu que o Zn estava associado, principalmente, 
aos óxidos de $\mathrm{Fe}$ e às argilas. Esse autor comparou solos com teores de argila variando entre 2 a $28 \%$ e observou correlação entre a textura e a retenção de Zn. Kalbasi \& Racz (1978), estudando solos com diferentes texturas, observaram correlação positiva entre o teor de argila e adsorção de $\mathrm{Zn}$ devido, sobretudo, ao recobrimento dos óxidos livre de $\mathrm{Fe}$ e $\mathrm{Al}$ na superfície das argilas silicatadas. Esses autores sugerem que o efeito do recobrimento dos óxidos na superfície dos minerais de argila, apesar de mais acentuado em solos com textura fina, pode ocorrer, em menor intensidade, em solos com textura arenosa, principalmente nos horizontes mais profundos, devido à formação de concreções ferruginosas. A retenção de $\mathrm{Zn}$ pelos óxidos de Fe envolve mecanismos de troca iônica (adsorção não-específica) e ligações covalentes (adsorção específica). Kalbasi et al. (1978) observaram que, dependendo do pH, de 60 a $90 \%$ do $\mathrm{Zn}$ total estava adsorvido nos óxidos de Fe por meio de reações específicas, e que de 40 a $10 \%$ do metal estava adsorvido de forma não-específica.

Nas amostras do LVwf tratadas com biossólido, embora a maior parte do Zn estivesse retida nas frações Fe crist. e Res, as frações Superf.Ox. e Ox. Mn foram as que apresentaram maior incremento na retenção de $\mathrm{Zn}$ em relação às amostras originais. Em $\mathrm{pH}$ 7, o LVwf tratado com biossólido apresentou $58 \%$ do $\mathrm{Zn}$ total associado às frações Fe crist. e Res, e a fração Superf. Ox. passou a reter aproximadamente $27 \%$ do total nesse $\mathrm{pH}$. Esse aumento na fração Superf. Ox. deve-se a interação do metal com a fração carbonato nesse valor de $\mathrm{pH}$. Com o aumento da acidez houve aumentou na porcentagem do metal retido em formas trocáveis. As porcentagens de $\mathrm{Zn}$-Troc. estão de acordo com os resultados obtidos por Sims (1986), que encontrou 1 a $53 \%$ do Zn total na forma trocável, numa faixa de $\mathrm{pH}$ entre 4,1 a 7,5. A fração Troc. variou de 0 a $37 \%$ do $\mathrm{Zn}$ total, seguido de uma redução na porcentagem do metal retido na fração Superf. Ox. (de $27 \%$ para $6 \%$, nos valores de $\mathrm{pH}$ entre 7 e 4 , respectivamente). A diferença na distribuição de $\mathrm{Zn}$ em função do $\mathrm{pH}$ pode ser devida à forma na qual o metal é retido no solo. Em pHs mais baixos (meios ácidos), o Zn pode ser retido no solo por reações de troca, enquanto em pHs mais elevados, mecanismos de adsorção específica passam a ser mais importantes (McBride \& Blasiak, 1979). Shukla et al. (1980) também observaram que o $\mathrm{Zn}$, em valores de $\mathrm{pH}$ baixos, era adsorvido no complexo de troca dos solos. 
Jeffery \& Uren (1983) reafirmaram a existência ambos mecanismos de retenção de Zn nos solos e, no caso de solos contaminados com o metal e em baixos valores de $\mathrm{pH}$, as reações de adsorção não-específicas foram predominantes.

No LAd, ao contrário do LVwf, tanto nas amostras originais como nas equilibradas com biossólido, não foi detectado $\mathrm{Zn}$ associado às frações Fe Crist. e Res (Figura 16). Isso se deve, possivelmente, aos menores conteúdos de argila e de óxidos de Fe cristalinos nesse solo (Tabelas 4 e 5). No LAd, as frações Fe Ox. e Ox. Mn foram as mais importantes na retenção do metal na amostra original. Esses resultados foram semelhantes aos observados por Kalbasi \& Racz (1978). Esses autores sugeriram que, embora o Zn estivesse associado aos óxidos de Fe e Mn em solos com textura grosseira, o metal estava ocluso ou coprecipitado apenas com os óxidos de $\mathrm{Fe}$. No pH 7, a fração Superf. Ox. passou a reter $74 \%$ do $\mathrm{Zn}$ total, e a participação relativa na adsorção das frações Fe Ox. e Ox. Mn foi reduzida. Porém, à medida que se aumentou a acidez da solução, a maior parte do $\mathrm{Zn}$ encontrou-se na fração Troc. Por exemplo, no pH 4, cerca de $82 \%$ do Zn estava na forma trocável. Esse valor foi superior ao encontrado por Sims (1986) para o mesmo $\mathrm{pH}$, porém em um solo com maior conteúdo de matéria orgânica. Já no LVwf, no $\mathrm{pH}$ 4, cerca de $37 \%$ do $\mathrm{Zn}$ total encontrava-se na fração Troc. Esse aumento no Zn-trocável deve ser considerado em áreas que recebem resíduos contendo o metal, uma vez que esse é considerado o metal mais móvel e biodisponível em solos minerais ligeiramente ácidos (Kabata-Pendias \& Pendias, 1987). Concordando com essa hipótese, Sims (1986) observou que, em geral, havia uma correlação entre a absorção de $\mathrm{Zn}$ pelas plantas, o $\mathrm{pH}$ do solo e a fração Zn-trocável $\mathrm{O}$ efeito da redução do $\mathrm{pH}$ no aumento das formas trocáveis foi mais acentuado no LAd do que no LVwf, possivelmente devido à maior contribuição dos óxidos de $\mathrm{Fe}$ e da presença de caulinita na fração residual nesse último solo, o que lhe conferiu maior afinidade em reter $\mathrm{Zn}$ (Figura 3).

A distribuição de $\mathrm{Zn}$ no tratamento F.I. foi semelhante àquelas das amostras incubadas no $\mathrm{pH}$ 6. O aumento na concentração de cálcio, devido ao aumento na força iônica da solução, provavelmente não interferiu na adsorção de $\mathrm{Zn}$ nos solos. Esse resultado concorda com o obtidos por Shukla et al (1980), que não encontraram efeito do 
cálcio na adsorção de $\mathrm{Zn}$, uma vez que esse cátion é predominante no complexo de troca dos solos. Porém, Shuman (1986) encontrou um efeito negativo do aumento da força iônica da solução na adsorção de Zn. Esse autor observou que os parâmetros das isotermas de adsorção de $\mathrm{Zn}$ eram semelhantes numa faixa de força iônica variando entre $0,005-0,1 \mathrm{~mol} \mathrm{~L} \mathrm{~L}^{-1}$, porém o valor absoluto de $\mathrm{Zn}$ adsorvido foi aproximadamente dez vezes superior no menor valor de força iônica. $\mathrm{O} p H$ da solução foi ao redor de 6 e nesse valor os mecanismos de adsorção específicos são mais importantes na retenção do metal do que os sítios de troca. No F.I. houve ligeiro aumento no $\mathrm{Zn}$ associado à fração Ox.Mn no LVwf e nas frações MO e Fe Ox no LAd. No LAd a porcentagem do ZnTroc. foi reduzido de $26 \%$ no tratamento a $\mathrm{pH} 6$ para $3 \%$ no tratamento F.I.

Em ambas as amostras de biossólido, equilibrada com o LVwf ou com o LAd, a distribuição de $\mathrm{Zn}$ foi semelhante (Figura 17). Na amostra original, as frações Ox. Mn, Superf. Ox. e Fe crist. representaram $80 \%$ do $\mathrm{Zn}$ total da amostra. Porém, com a redução do $\mathrm{pH}$, houve diminuição na quantidade do metal retido na fração Superf. Ox. e, correspondente aumento na fração Troc. A redução na fração Superf. Ox. pode ser explicada pela eliminação dos carbonatos presentes no biossólido com a diminuição do pH. Com relação à fração trocável, enquanto no $\mathrm{pH} 7$ não foi detectado $\mathrm{Zn}$ associado a essa fração, no pH 4 os valores variaram entre 18-24 \% do $\mathrm{Zn}$ total. Petruzzelli et al. (1994) encontraram em torno de 0,05 a $0,9 \%$ do Zn associado com a fração trocável em diversos biossólidos. Esses autores observaram que, embora a concentração de $\mathrm{Zn}$ total nos biossólidos fossem bastante semelhantes, a distribuição do metal nas frações era ligeiramente diferente.

\subsubsection{Distribuição de Cu nas amostras}

As quantidades de $\mathrm{Cu}$ adsorvidos em ambos os solos foram maiores com o aumento da acidez do solo (Figuras 18 e 19). Esses resultados não concordam com os obtidos por Barrow et al. (1981) e Msaky \& Calvet (1990) para adsorção de Cu. Isso se deve, principalmente, às menores quantidades de $\mathrm{Cu}$ retidas no biossólido com a redução do pH da solução e, conseqüente, maior disponibilização do metal para ser adsorvido 


\section{LVwf}
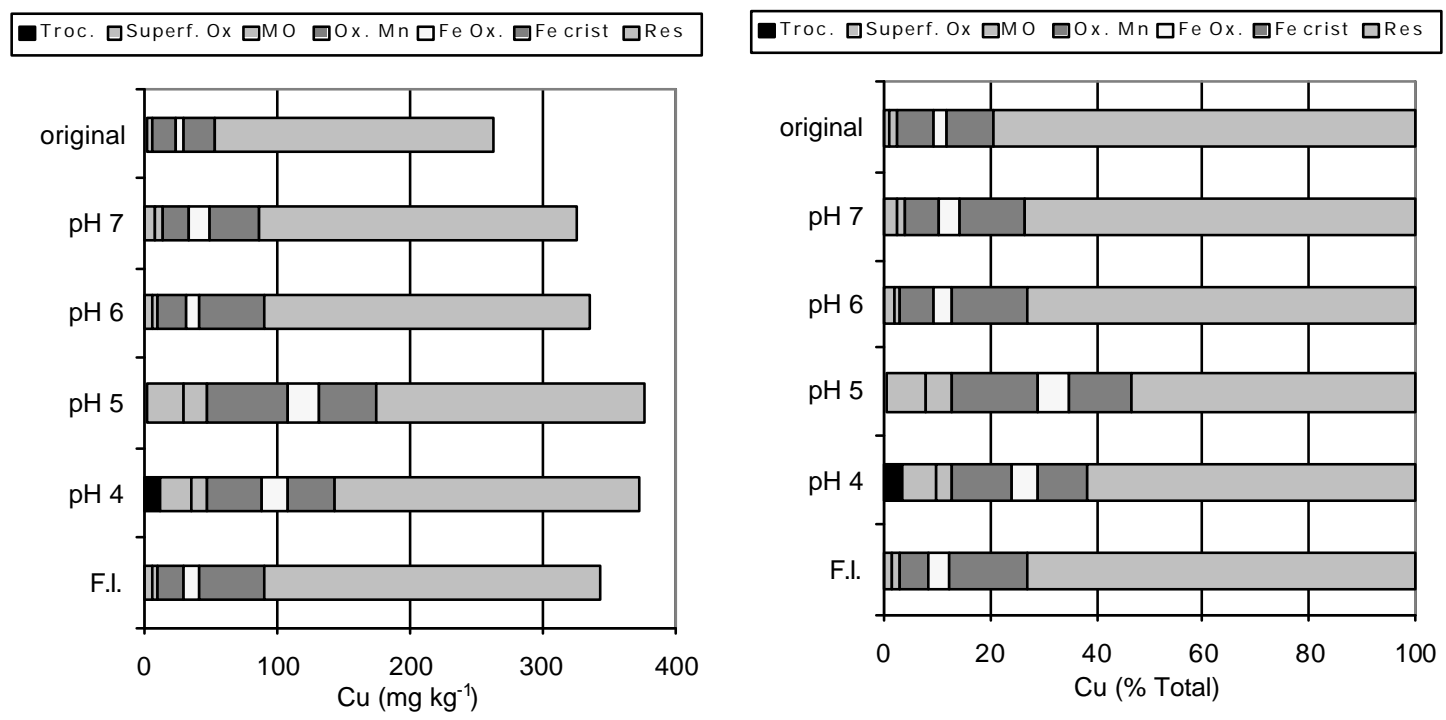

\section{LAd}

$\square^{\text {Troc. }} \square^{\text {Superf. Ox }} \square^{\text {MO }} \square^{\text {Ox. Mn }} \square^{\text {Fe Ox. }} \square^{\text {Fe crist }} \square^{\text {Res }}$

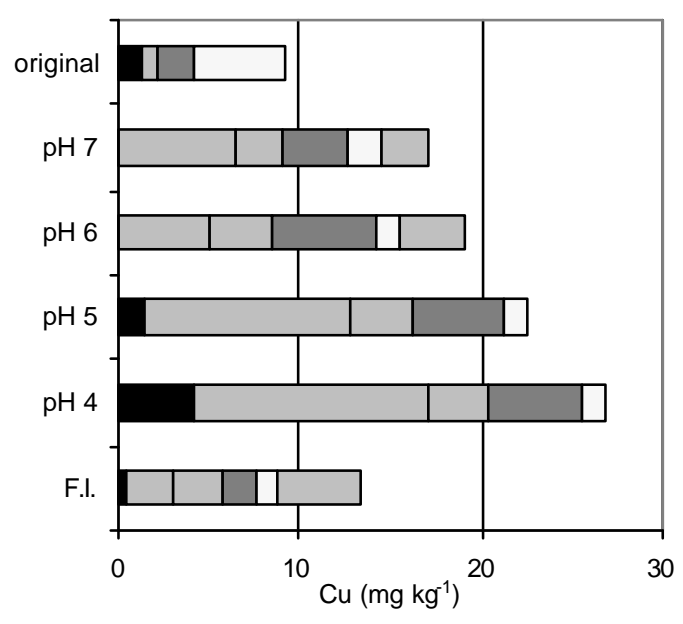

$\square^{\text {Troc. }} \square^{\text {Superf. Ox }} \square^{\text {MO }} \square^{\text {Ox. Mn }} \square^{\text {Fe Ox. }} \square^{\text {Fecrist }} \square^{\text {Res }}$

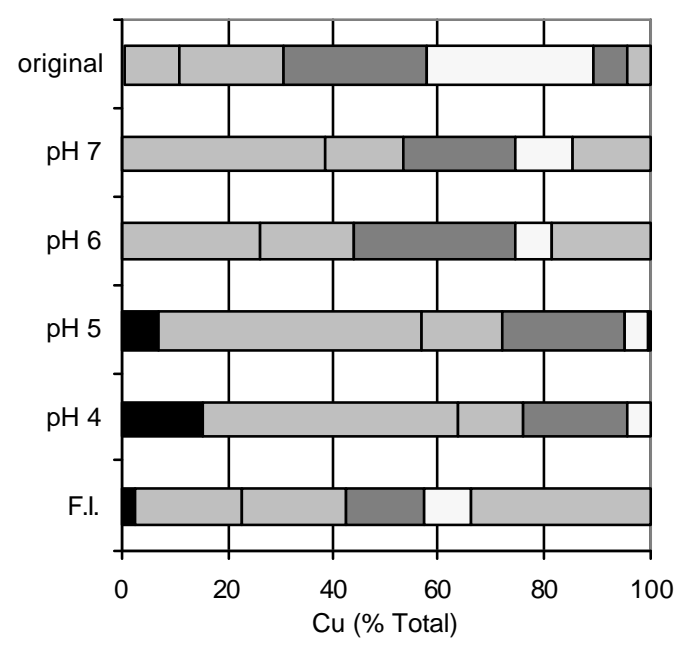

Figura 18 - Extração seqüencial de $\mathrm{Cu}$ nas amostras de terra após o equilíbrio nas câmaras. 


\section{Biossólido 1*}
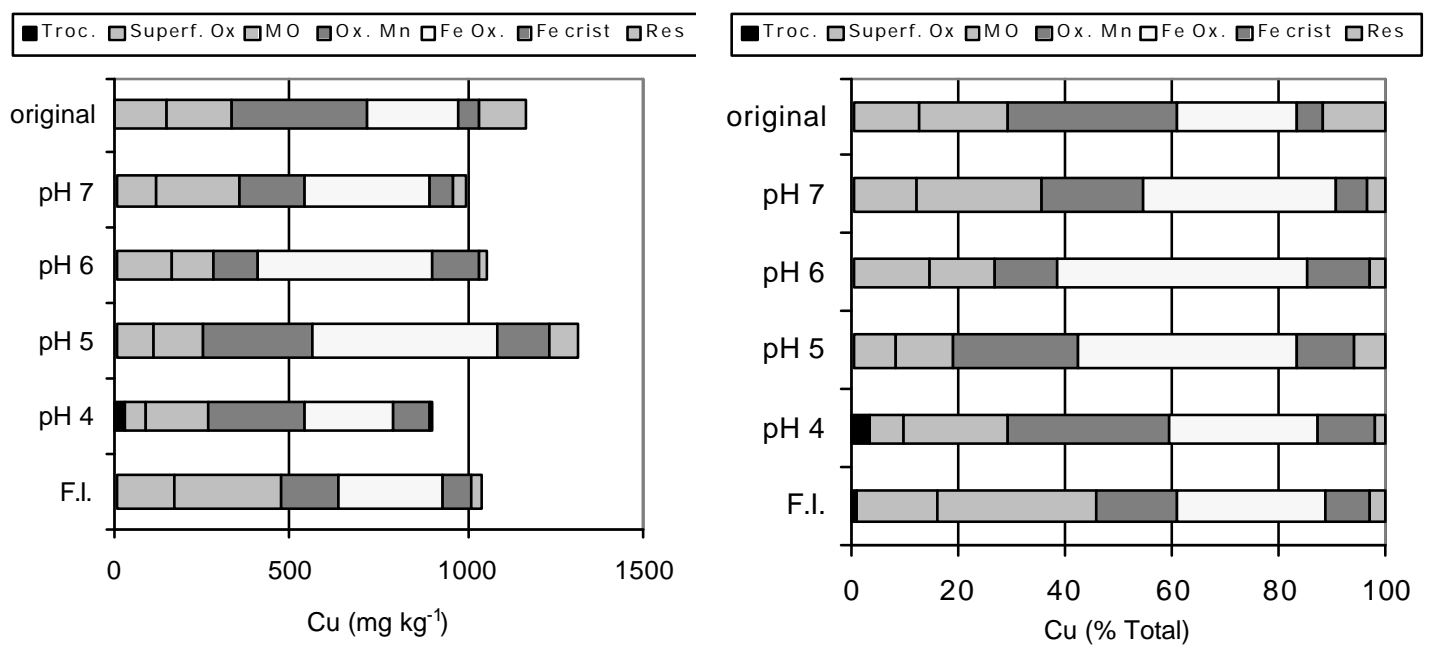

Biossólido 2**
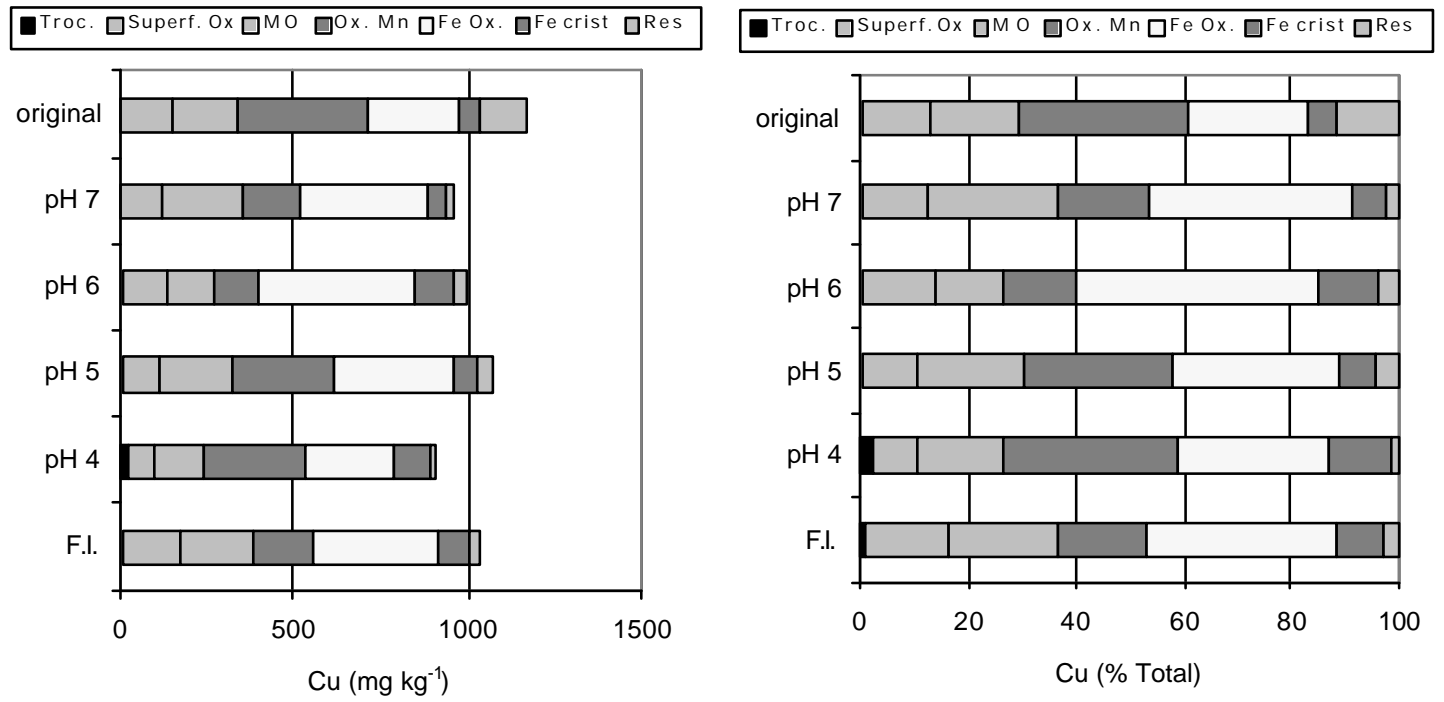

Figura 19 - Extração seqüencial de Cu nas amostras de biossólido após o equilíbrio nas câmaras. **Biossólido 1= equilibrado com o LVwf; **Biossólido 2= equilibrado com o LAd. 
pelos solos. Ao contrário do $\mathrm{Zn}$, para o $\mathrm{Cu}$ a maior disponibilização do metal do biossólido resultou em maior adsorção do mesmo pelas amostras de solo.

O cobre esteve associado às frações pouco solúveis em ambos os solos (Figura 18). No $\mathrm{pH}$ mais baixo, apenas $16 \%$ do $\mathrm{Cu}$ total estava presente na solução no LAd e 3 $\%$ no LVwf, enquanto no $\mathrm{pH}$ mais elevado, esse valor foi ao redor de zero em ambos os solos. O efeito do pH na quantidade do metal em solução e/ou adsorção e distribuição do metal no solo não foi tão acentuado quando comparado ao $\mathrm{Zn}$. Esses resultados concordam com os obtidos por Jeffery \& Uren (1983), que não encontraram dependência acentuada entre o cobre solúvel e o pH do solo, com exceção de áreas contaminadas com o metal. Corroborando esses resultados, Sims (1986) não observou mudanças na distribuição de $\mathrm{Cu}$ na faixa de $\mathrm{pH}$ entre 4,1 e 7,5. Um dos motivos para essa resposta é que o $\mathrm{Cu}$ é retido no solo de forma diferenciada em relação ao $\mathrm{Zn}$ e ao Cd. McBride \& Blasiak (1979), conduzindo testes de adsorção de Cu e Zn, concluíram que os valores de $\mathrm{pH}_{50}$ para ambos os metais eram iguais a 4,4 e 5,4, respectivamente. Para esses autores, os hidróxidos de $\mathrm{Fe}$ e $\mathrm{Al}$ do solo adsorveram primeiramente o $\mathrm{Cu}$ e, posteriormente, o $\mathrm{Zn}$. Sugere-se ainda que existam dois mecanismos opostos que controlam a solubilidade de cobre no solo: 1) adsorção de $\mathrm{Cu}$ pelos colóides do solo, reduzindo sua concentração em solução; 2) agentes complexantes solúveis competem por sítios de adsorção com o Cu-livre, desfavorecendo sua adsorção (Jeffery \& Uren, 1983). Forbes et al (1976) citaram que o cobre foi o metal mais fortemente adsorvido em pHs elevados, e a ordem de adsorção dos metais pesados nos solos com o aumento do pH foi igual a: $\mathrm{Cu}>\mathrm{Pb}>\mathrm{Zn}>\mathrm{Co}>\mathrm{Cd}$. Com relação à fração $\mathrm{MO}$, os resultados de $\mathrm{Cu}$ obtidos nessa fração para ambos os solos foram inferiores aos encontrados por Sims (1986). Cerca 1-5 \% do Cu total estava presente na fração MO do LVwf e 12-20 \% do $\mathrm{Cu}$ total no LAd, enquanto Sims (1986), utilizando o mesmo reagente utilizado para extrair a fração $\mathrm{MO}$, encontrou aproximadamente de 6-73 \% do $\mathrm{Cu}$ total. Porém, os solos estudados por esse autor apresentavam teores de matéria orgânica superiores aos dos Latossolos, e o método de extração seqüencial utilizado não continha a remoção da fração Superf.Ox., o que pode ter contribuído para superestimar a quantidade de $\mathrm{Cu}$ associado à fração MO. Ao contrário dos resultados obtidos por Sposito et al. (1982a), 
quando se compara a fração MO das amostras de solo originais e tratadas com biossólido, não foi observado aumento do Cu nessa fração.

$\mathrm{O}$ tratamento F.I. não promoveu mudanças na distribuição de $\mathrm{Cu}$ nas amostras de terra e de biossólido, quando comparado ao tratamento no mesmo valor de $\mathrm{pH}$ (Figuras 18 e 19). Apenas no LAd houve ligeiro aumento na porcentagem de $\mathrm{Cu}$-Troc. (de 0 para $3 \% \mathrm{Cu}$ total) quando se comparam os tratamentos a pH 6 e o F.I. As quantidades de $\mathrm{Cu}$ adsorvidas pelos solos e a dissolução do biossólido não foram alteradas pelo aumento da força iônica da solução. Esses resultados discordam dos obtidos por Petruzelli et al. (1985), que observaram redução na adsorção de $\mathrm{Cu}$ com o aumento da força iônica da solução.

$\mathrm{Na}$ amostra original do LVwf, cerca de $79 \%$ do $\mathrm{Cu}$ estava associado à fração Res (Figura 18). McLaren \& Crawford (1973) encontraram valores semelhantes de $\mathrm{Cu}$ associado aos minerais de argila (77 \% do $\mathrm{Cu}$ total) e concluíram que essa fração era responsável pela maior parte da retenção do $\mathrm{Cu}$ total do solo. Em seguida, a fração $\mathrm{Fe}$ crist. foi responsável por reter cerca de $9 \%$ do Cu total. Forbes et al. (1976) observaram que o $\mathrm{Cu}$ foi o metal com maior afinidade em ser adsorvido por óxidos de $\mathrm{Fe}$, mais especificamente goethita, e que a seqüência de afinidade para os demais metais pesados foi igual a: $\mathrm{Cd}<\mathrm{Co}<\mathrm{Zn}<\mathrm{Pb}<\mathrm{Cu}$. Nesse solo, o $\mathrm{Cu}$ estava presente em formas não difusíveis, provavelmente incorporado na estrutura cristalina dos minerais. Após o equilíbrio com o biossólido, o $\mathrm{Cu}$ foi distribuído de forma equivalente dentre as frações. Embora as quantidades de $\mathrm{Cu}$ retidas no LVwf sejam diferentes, após o tratamento com biossólido e na amostra original, a distribuição relativa do metal foi semelhante. A porcentagem de $\mathrm{Cu}$ retido no Res foi ligeiramente diminuída nos pHs 5 e 4 (53 e $62 \%$ do $\mathrm{Cu}$ total, respectivamente), porém esse comportamento foi acompanhado de um aumento na retenção de $\mathrm{Cu}$ na fração Óx. Mn.

Em contrapartida, na amostra original do LAd, ao redor de $79 \%$ do $\mathrm{Cu}$ foi retido nas frações Fe Ox., Ox. Mn e MO (Figura 18). A porcentagem de $\mathrm{Cu}$ retido na fração $\mathrm{Fe}$ Ox. (32\% do $\mathrm{Cu}$ total) concorda com os resultados de McLaren \& Crawford (1973) que, utilizando o mesmo extrator, obtiveram cerca de $35 \%$ do $\mathrm{Cu}$ associado a essa fração. Confirmando esses resultados, Abd-Elfattah \& Wada (1981) encontraram que os óxidos 
de $\mathrm{Fe}$ mal cristalizados foram os componentes mais seletivos na adsorção de $\mathrm{Cu}$. Kabata-Pendias \& Pendias (1987) ressaltam a associação de $\mathrm{Cu}$ com os óxidos de $\mathrm{Fe}$ e Mn e as formas mal cristalizadas. Nas amostras tratadas com biossólido, no pH 7, apenas $47 \%$ do $\mathrm{Cu}$ estava associado às três frações citadas anteriormente. A fração Superf. Ox. passou a reter a maior parte do metal, com o aumento da acidez da solução. No $\mathrm{pH} 4$, cerca de $48 \%$ do $\mathrm{Cu}$ foi encontrado relacionado à essa fração.

O comportamento das amostras de biossólido, originais e equilibrada com os solos, foi bastante semelhante (Figura 19). As frações Ox. Mn, Fe Ox. e MO foram as principais responsáveis pela retenção de $\mathrm{Cu}$ nesse resíduo. Com a diminuição do $\mathrm{pH}$ houve ligeiro aumento na porcentagem do metal associado à fração trocável (de 0 para 3 \% do $\mathrm{Cu}$ total) e uma redução na participação da fração Superf. Ox. na retenção de $\mathrm{Cu}$ (de 12 para $6 \%$ do $\mathrm{Cu}$ total). Petruzzelli et al. (1994), estudando várias amostras de biossólido, encontraram valores semelhantes de $\mathrm{Cu}$-Troc. para uma amostra de biossólido, porém dependendo das características desse material, o teor de $\mathrm{Cu}$ associado à fração trocável pode ser até cinco vezes superior. Esses autores consideram que os metais na fração Troc. do biossólido são retidos por forças de Coulomb ou de van der Waals. Embora a quantidade de $\mathrm{Cu}$ retida na fração trocável seja proporcionalmente menor em relação às demais, essa forma do metal pode ser considerada facilmente disponível para ser absorvida pelo planta.

\subsubsection{Distribuição de Cd nas amostras}

O cádmio foi o metal que teve maior incremento na concentração total nas amostras de terra após a incubação com o biossólido (Figuras 20 e 21). A quantidade de Cd adsorvido nos solos após o tratamento com o biossólido variou entre 0,8 e $7 \%$ do Cd total. No pH 4, no qual a solubilização de $\mathrm{Cd}$ do biossólido foi maior, o incremento na concentração do metal nas amostras de terra foi, em $\mathrm{mg} \mathrm{kg}^{-1}$, de 0,22 na amostra original do LVwf para 11,5 na amostra tratada com o biossólido, e no LAd de 0,15 para 4 nas amostras original e incubada, respectivamente. Isso representou um aumento de 52 vezes no teor original de Cd no LVwf e 27 vezes no LAd. Akhter (1990) observou resultados 


\section{LVwf}
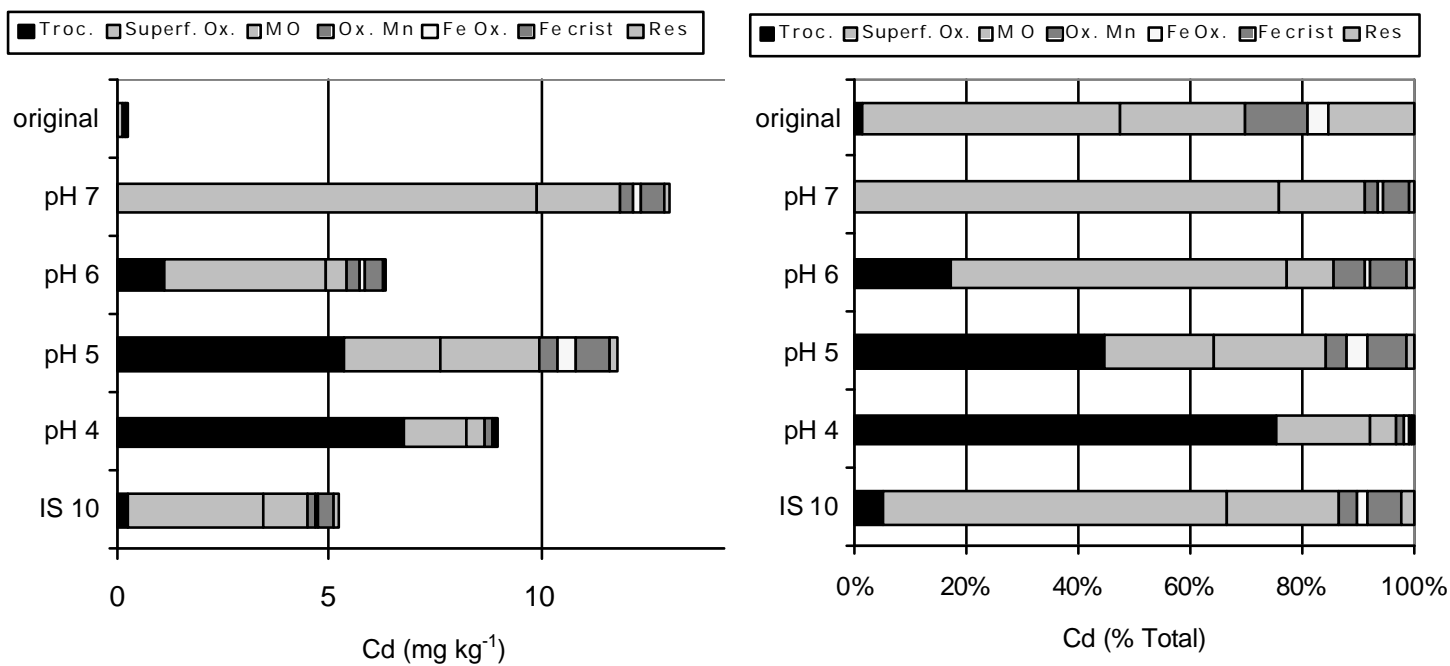

\section{LAd}
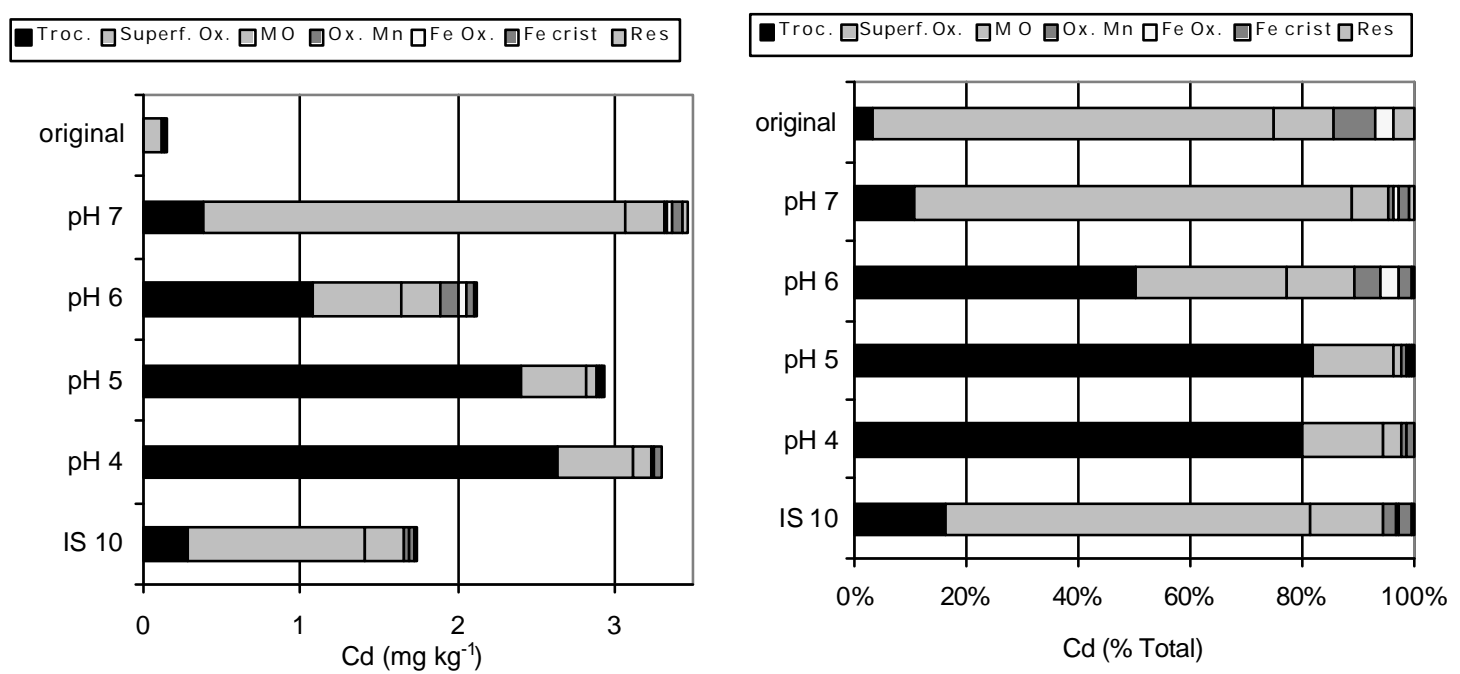

Figura 20 - Extração seqüencial de Cd nas amostras de terra após o equilíbrio nas câmaras. 
Biossólido 1*
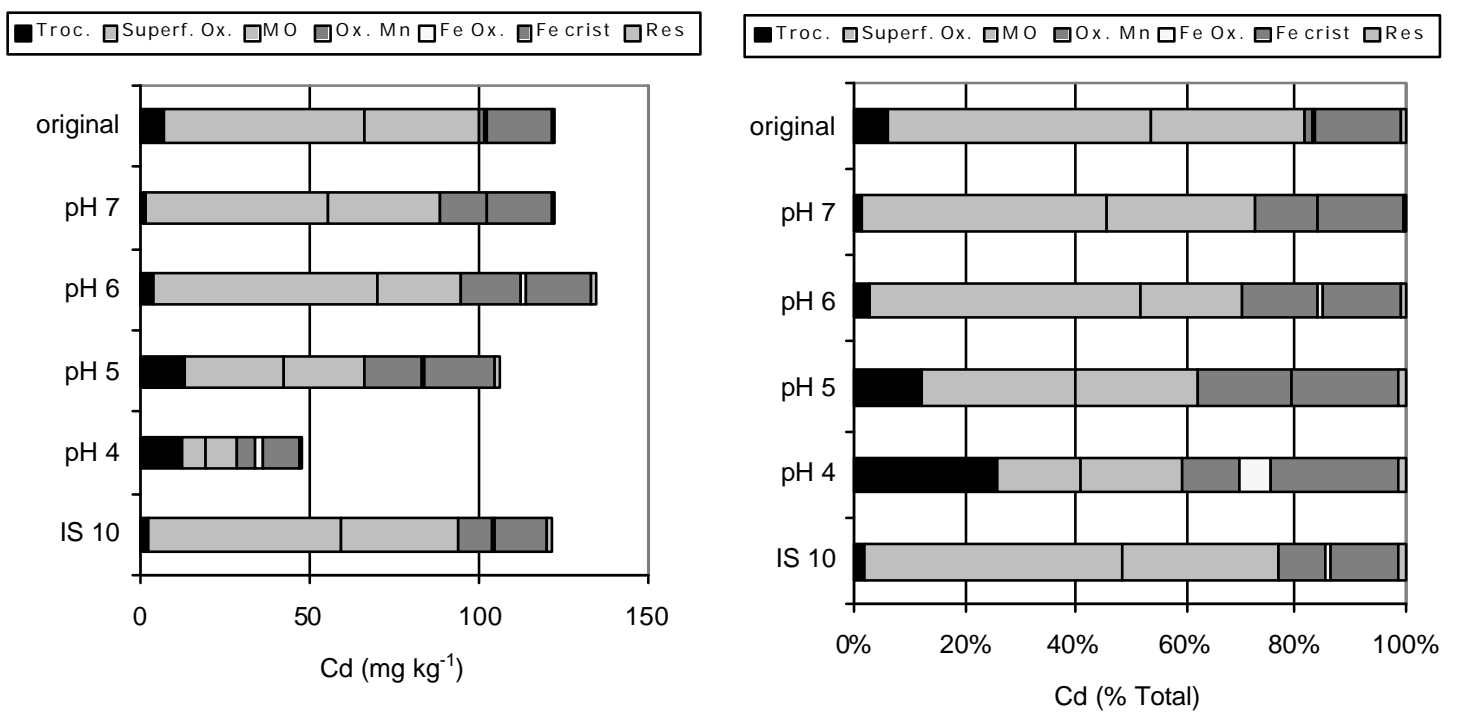

Biossólido 2**

$\square^{\text {Troc. }} \square^{\text {Superf. Ox. }} \square^{\text {MO }} \square^{\text {Ox. Mn }} \square^{\text {Fe Ox. }} \square^{\text {Fecrist }} \square^{\text {Res }}$

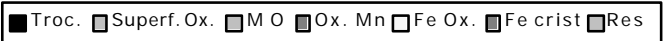
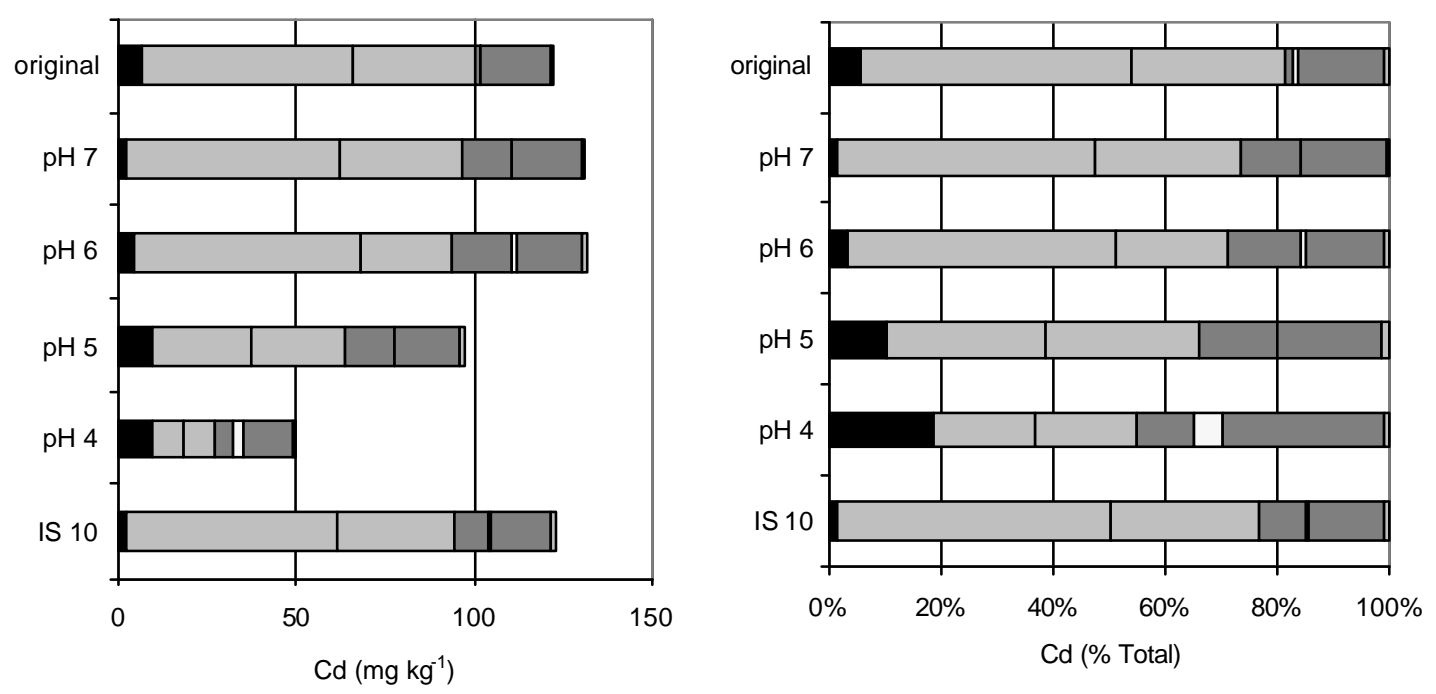

Figura 21 - Extração seqüencial de Cd nas amostras de biossólido após o equilíbrio nas câmaras. **Biossólido 1= equilibrado com o LVwf; **Biossólido 2= equilibrado com o LAd. 
semelhantes, ou seja, o incremento principalmente de Cd no solo após a aplicação de biossólido por um ano. Esse autor apontou o risco de contaminação dos solos com Cd e $\mathrm{Pb}$ na área estudada devido, sobretudo, ao clima quente e úmido, e ressaltou a necessidade do constante monitoramento dos níveis desses metais nos solos tratados com biossólidos. $\mathrm{O}$ acúmulo mais acentuado de $\mathrm{Cd}$ nos solos em relação aos demais metais pode ser considerado um indicativo dos riscos de aplicação de biossólidos com elevados teores desse metal nos Latossolos. Em solos com pHs baixos, os metais podem tornar-se mais móveis e biodisponíveis em relação a meios alcalinos (Palazzo \& Reynolds, 1991). Na faixa de $\mathrm{pH}$ entre 4,5 a 5,5 o Cd encontra-se, predominantemente, nas formas móveis (Kabata-Pendias \& Pendias, 1987). Portanto, além das condições climáticas favoráveis ao acúmulo de $\mathrm{Cd}$ nos solos tropicais, o $\mathrm{pH}$ ácido pode potencializar os riscos de transporte e contaminação do meio ambiente. Kabata-Pendias \& Pendias (1987) citaram diversas fontes de contaminação de Cd em solos, dentre elas o uso de biossólidos e consideraram que a poluição dos solos por esse metal como sendo um dos riscos mais sérios a saúde. Entretanto, os efeitos a longo prazo da adição de Cd nos solos ainda não são bem definidos. Palazzo \& Reynolds (1991), estudando solos que receberam tratamento com biossólidos, observaram que o aumento na concentração de Cd foi mais acentuado após as primeiras aplicações do resíduo. Porém, após dezesseis anos do término da aplicação todos os metais estudados, incluindo cádmio, tiveram sua concentração reduzida nos solos. Esses autores sugerem que, embora o $\mathrm{Cd}$ possa ser inicialmente lixiviado no perfil ou transportado via escorrimento superficial, com o tempo os mecanismos de imobilização e complexação do metal com materiais orgânicos são favorecidos devido à aplicação dos biossólidos. Práticas de manejo adotadas após o término da aplicação dos biossólidos, tais como a aplicação de fertilizantes nitrogenados, que podem reduzir o $\mathrm{pH}$ do solo, além da adição de ligantes orgânicos e inorgânicos $(\mathrm{Cl}$ ), influenciam a mobilidade dos metais nos solos (Evans et al., 1995).

A diminuição do $\mathrm{pH}$ ocasionou maior disponibilização de $\mathrm{Cd}$ do biossólido (Figura 21). Por exemplo, no pH 7, entre 91 e $94 \%$ do Cd apresentava-se no biossólido, enquanto no $\mathrm{pH} 4$, esse valor foi da ordem de $30 \%$ do $\mathrm{Cd}$ total. Assim como esperado, a maior dissolução do biossólido foi acompanhada de uma elevação na concentração do 
metal em solução. No pH mais elevado, apenas $1 \%$ do $\mathrm{Cd}$ total estava presente em solução; porém, no meio mais ácido, $68 \%$ do metal estava em solução. Esse comportamento dos biossólidos em disponibilizar quantidades significativas de $\mathrm{Cd}$ em solução em pHs baixos pode ser um indicativo dos possíveis efeitos prejudiciais do uso de biossólidos contendo elevados teores de $\mathrm{Cd}$ em solos ácidos. $\mathrm{O} \mathrm{Cd}$ ligado ao biossólido foi mais facilmente disponibilizado na solução em comparação aos demais metais, sobretudo ao $\mathrm{Cu}$. Possivelmente, os mecanismos que retém esse metal na matriz do biossólido são mais facilmente afetados pelas variações do $\mathrm{pH}$ do meio. Isso pode ser comprovado pela distribuição do metal nos biossólidos (Figuras 21). A maior parte do metal estava associada às frações Superf.Ox. e MO (aproximadamente $76 \%$ do $\mathrm{Cd}$ total). Devido ao elevado $\mathrm{pH}$ desse material, a fração Superf. Ox. pode conter carbonatos, que contribuem na retenção do $\mathrm{Cd}$ na fase sólida. Dentre os metais estudados, o $\mathrm{Cd}$ pode encontrar-se mais facilmente coprecipitado com carbonatos na fase sólida (Sposito, 1983). À medida que o pH é reduzido, os carbonatos tendem a serem solubilizados e, conseqüente, ocorre a redução na importância da fração Superf.Ox. em reter o $\mathrm{Cd}$. Assim como nos solos, nos valores de $\mathrm{pH}$ mais baixos houve maior participação da fração Troc. (entre 19-26 \% do Cd total no pH 4) na retenção do metal (Figura 21). A solubilidade do Cd parece ser altamente dependente do $\mathrm{pH}$ do meio (Kabata-Pendias \& Pendias, 1987).

$\mathrm{O}$ aumento do $\mathrm{Cd}$ em solução não foi acompanhado de uma adsorção proporcional pelos solos (Figura 20). No LAd, em todos os valores de $\mathrm{pH}$ estudados, cerca de $2 \%$ do $\mathrm{Cd}$ foi retido no solo, independentemente da quantidade do metal em solução, enquanto para o LVwf, esse valor variou de 5 a $8 \%$ do Cd total. Isso pode ser devido à saturação dos sítios de retenção de metais nos solos nessas condições. Os principais constituintes dos solos importantes na retenção de metais, tais como os óxidos de Fe, minerais de argila e matéria orgânica apresentam menor afinidade em adsorver Cd em relação aos demais metais (Alloway, 1990). Portanto, em condições nas quais o $\mathrm{Zn}$, o $\mathrm{Cu}$ e o $\mathrm{Cd}$ podem competir pelos sítios de adsorção dos colóides, esse último metal tem menor habilidade em ser adsorvido pelos solos. Esses resultados apontam novamente para os riscos de contaminação por esse elemento, sobretudo em meios 
ácidos, uma vez que a maior parte do metal se encontra na solução e é passível de ser absorvido pelas plantas. Alguns autores consideram o que $\mathrm{Cd}$ é o metal que apresenta os riscos mais sérios para a saúde humana (Kabata-Pendias \& Pendias, 1987; Smith, 1994b). Porém, embora a mobilidade do Cd seja altamente dependente do $\mathrm{pH}$, a natureza da superfície sorvente e os ligantes orgânicos são fatores importantes na lixiviação do metal no perfil (Kabata-Pendias \& Pendias, 1987). Esses autores apontam que o Cd encontra-se em formas móveis em solos ácidos na faixa de $\mathrm{pH}$ entre 4,5 e 5,5. Com a elevação do pH, há tendência de formar em espécies iônicas tais como $\mathrm{CdOH}^{+}$, que podem ser facilmente retidas no complexo de troca.

O aumento na força iônica da solução não proporcionou maior concentração de $\mathrm{Cd}$ em solução e, em geral, as quantidades do metal retidas no biossólido ou adsorvidas pelos solos foram semelhantes às do tratamento no pH 6 (Figuras 20 e 21). Nessas condições, o aumento do íon $\mathrm{Cl}$ não ocasionou maior dessorção do $\mathrm{Cd}$ do biossólido como observado por Sauvé et al. (2000), que estudando métodos de extração de solução de solo, observaram maior quantidade de Cd extraído quando o CI estava presente na solução. Nos solos, o aumento na força iônica da solução promoveu incremento na porcentagem de $\mathrm{Cd}$ associado à MO e um decréscimo na porcentagem do metal trocável.

Nas amostras originais de ambos os solos, o $\mathrm{Cd}$ foi encontrado principalmente nas frações Superf.Ox e MO (Figura 20). Com o aumento na acidez da solução, a maior parte do Cd estava presente na forma trocável. Esse resultado foi acompanhado de uma diminuição na fração Superf. Ox. em ambos os solos. Na amostra original do LVwf, 46 \% do Cd estava associado com a fração Superf.Ox. e 22 \% com a MO. A fração Res na amostra original foi responsável por reter $16 \%$ do $\mathrm{Cd}$ total; porém a participação relativa dessa fração em reter o metal após a incubação com biossólido foi menor do que $1 \%$ do $\mathrm{Cd}$ total. Isso se deve a menor afinidade da fração mineral, nesse caso representado principalmente pela caulinita, em reter o $\mathrm{Cd}$ em relação ao $\mathrm{Zn}$ e ao $\mathrm{Cu}$ (Alloway, 1990). Após a incubação com o biossólido, no pH 7, foi encontrado 76 \% do Cd total apenas na fração Superf.Ox., sem aumento significativo na fração Troc., o que ocorreu porque em $\mathrm{pHs}$ elevados (ao redor de 7,5) o $\mathrm{Cd}$ encontra-se em formas pouco móveis (Kabata-Pendias \& Pendias, 1987). Porém, no pH mais baixo $(\mathrm{pH}=4)$, cerca de 
$75 \%$ do metal estava na fração Troc. e apenas $17 \%$ do total na Superf.Ox. Esses resultados foram superiores aos obtidos por Kuo et al. (1983), que encontraram de 30 a $60 \%$ do Cd total na fração trocável, em solos com menores teores do metal. Esses resultados confirmam as conclusões de Abd-Elfattah \& Wada (1981) que, em alguns casos, o Cd era retido nos solos, principalmente, por reações de troca iônica. Porém, Morera et al. (2001) não detectaram Cd extraído com o mesmo reagente utilizado para acessar a fração Superf. Ox. e/ou associado à fração trocável. A diferença nos resultados pode ser devida à concentração de Cd bastante inferior nos solos estudados por Morera et al. (2001) em comparação a dos Latossolos tratados com biossólido. Essa hipótese se confirmou quando esses autores adicionaram doses conhecidas de $\mathrm{Cd}$, o que ocasionou na mudança na distribuição na fase sólida, ou seja, parte do metal estava associado à fração trocável nos solos. Esses autores sugerem que os metais, dentre eles o $\mathrm{Cd}$, quando adicionados em doses elevadas apresentam menor afinidade de retenção pelos colóides (verificado pelo menor valor do coeficiente de distribuição- $\mathrm{K}_{\mathrm{d}}$ ), e que os sítios com elevada energia de adsorção estão presentes em menor quantidade nos solo do que os de baixa energia de ligação.

Embora os Latossolos exibam atributos contrastantes e diferentes capacidades em adsorver o $\mathrm{Cd}$, a distribuição desse metal, em termos percentuais, foi bastante semelhante em ambos os solos. Assim como no LVwf, o Cd na amostra original do LAd foi encontrado principalmente nas frações Superf.Ox. e MO (82 \% do Cd total). Mesmo nas amostras originais dos solos, o $\mathrm{Cd}$ esteve associado a frações potencialmente biodisponíveis. Além disso, as frações Superf. Ox. e MO e, conseqüentemente, a distribuição de $\mathrm{Cd}$ nos solos pode ser modificada pela acidificação do solo e/ou mineralização da matéria orgânica. Portanto, nesses solos, os mecanismos de retenção de Cd provavelmente não são estáveis e podem ser capazes de disponibilizar o elemento para solução. Nas frações Superf. Ox. e MO, o Cd pode ser absorvido pelas plantas, causando o acúmulo do metal no tecido vegetal. Kuo et al. (1983) sugeriram que a ligação entre o $\mathrm{Cd}$ e os complexos orgânicos não era estável nos colóides dos solos, e que poderia ser facilmente absorvido pelas plantas. A adição do biossólido ocasionou a elevação na concentração de Cd-Troc., e como esperado, nos valores mais baixos de pH, 
maior quantidade do metal foi retido nessa fração. Esse aumento na fração Troc. foi da ordem de $4 \% \mathrm{Cd}$ do total na amostra original para $11 \%$ no $\mathrm{pH} 7$; no $\mathrm{pH} 4$ esse valor foi igual a $80 \%$ do total. $\mathrm{O}$ aumento na quantidade de Cd-Troc. foi semelhante ao observado no LVwf, embora a quantidade do metal retido nesse último solo tenha sido superior.

\subsubsection{Especiação dos metais em solução}

A especiação dos metais mostrou que os três metais estudados, em geral, encontraram-se na forma livre (Tabela 15). Para ambos os solos, o aumento na acidez ocasionou maior concentração das "espécies-livres". Essa correlação negativa entre o pH e a atividade de íons-livres foi observada por Salam \& Helmke (1998) e Wu et al. (2000). A redução na atividade dos metais livres na solução com a elevação do pH pode ser devida à maior capacidade dos solos em adsorvê-los em meios alcalinos (Salam \& Helmke, 1998). Porém, a porcentagem de íons-livres nos pHs mais elevados foi maior para $\mathrm{Cd}$ do que $\mathrm{Zn}$ e $\mathrm{Cu}$. No $\mathrm{pH} 7$, no $\mathrm{LAd}$, apenas $2 \%$ do $\mathrm{Cu}$ estava presente como metal-livre, enquanto no LVwf não foi detectado $\mathrm{Cu}$ em solução. Em contrapartida, nesse mesmo valor de $\mathrm{pH}$, a porcentagem de metais-livres foi ao redor de $82 \%$ para o $\mathrm{Zn}$ e $88 \%$ para o $\mathrm{Cd}$. A menor quantidade de $\mathrm{Cu}$ em solução em relação aos demais metais pode ser devida à precipitação do mesmo na superfície dos colóides, resultando na redução do seu produto de solubilidade (Cavallaro \& McBride, 1980). Salam \& Helmke (1998) concluíram que a porcentagem de $\mathrm{Cu}^{2+}$ em solução era de 2 a 20 vezes inferior à de Cd. Wu et al. (2000), estudando solos contaminados por metais, observaram comportamento semelhante, ou seja, dentre vários metais, o $\mathrm{Cu}$ estava presente em menor concentração na forma livre. Em contrapartida, Jeffery \& Uren (1983) encontram a maior parte do Zn em solução encontrava-se como íon-livre ou complexos lábeis, porém o $\mathrm{Cu}$ estava presente, principalmente, como espécies não-lábeis ou moderadamente lábeis. Esses autores sugeriram que a explicação para essa diferença no comportamento desses metais em solução deve-se ao efeito diferenciado do $\mathrm{pH}$ na disponibilidade dos mesmos. Sauvé et al. (2000) observaram entre 0 a 60 \% (média igual 
Tabela 15 . Especiação iônica da solução após o equilíbrio nas câmaras-duplas de difusão

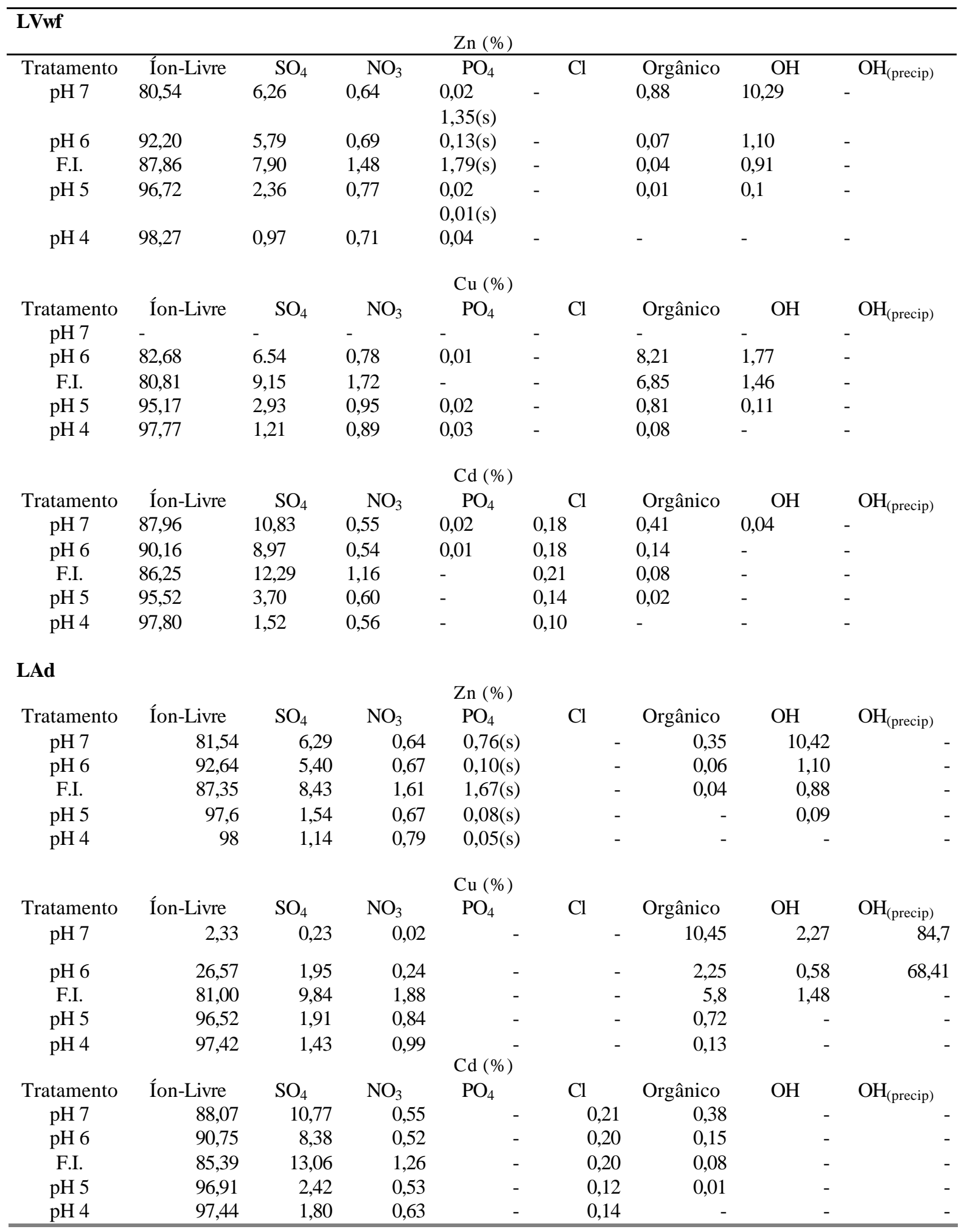


a $20 \%$ ) do $\mathrm{Cd}$ presente em solução na forma livre, e sugeriram que a dose do metal aplicada e o $\mathrm{pH}$ do solo foram os principais fatores que melhor explicaram a variação nos teores de Cd-livre em solução. Além do efeito direto do $\mathrm{pH}$ na especiação dos metais em solução nos Latossolos, o aumento na acidez do meio resultou em maior quantidade de metais disponibilizados do biossólido para a solução.

A maior quantidade de metais em solução nos $\mathrm{pHs}$ mais baixos pode ter sido importante na especiação dos mesmos, uma vez que, dependendo da concentração do metal em solução, a distribuição das espécies químicas em pode ser alterada (Percival et al., 1999). Por exemplo, o aumento na concentração de Cd favoreceu a formação de pares iônicos, mesmo com a redução do $\mathrm{pH}$ da solução. Isso pode ter ocorrido devido à hidrólise e ao deslocamento dos prótons do complexo de troca (Percival et al., 1999).

Os ligantes inorgânicos foram mais importantes na retenção dos metais estudados do que os orgânicos, com exceção do $\mathrm{Cu}$, no pH 7 (Tabela 15). Resultados semelhantes foram obtidos por Percival et al. (1999), que encontraram entre 90 a $95 \%$ dos complexos formados com os metais estavam associados com ligantes inorgânicos. Em geral, $\mathrm{o} \mathrm{SO}_{4}{ }^{2-}$ foi o ligante mais importante na formação de complexos com os três metais. Em contrapartida, a formação de complexos dos metais com o $\mathrm{NO}_{3}{ }^{-}$e o $\mathrm{Cl}^{-}$foi menos marcante, devido à menor habilidade desses ânions em ligar-se com os metais (Msaky \& Calvet, 1990). O íon $\mathrm{PO}_{4}{ }^{3-}$ ligou-se, preferencialmente, ao $\mathrm{Zn}$, resultando na formação de complexos e precipitados com esse metal. A afinidade do $\mathrm{Zn}$ em ligar-se com o $\mathrm{PO}_{4}{ }^{3-}$ foi reportada por Xu \& Schwartz (1994). Em ambos os solos, de 5 a $8 \%$ do $\mathrm{Zn}$ e entre 8 a $10 \%$ do $\mathrm{Cu}$ estavam ligados com o $\mathrm{SO}_{4}{ }^{2-}$ nos valores mais altos de $\mathrm{pH}(6$ e 7). Esse comportamento dos metais em ligar-se com o íon $\mathrm{SO}_{4}{ }^{2-}$ está de acordo com as informações de Sposito (1983), para quem, em solos ácidos o Cd e o Zn encontram-se principalmente como íons livres e, em menor proporção, complexados pelo $\mathrm{SO}_{4}{ }^{2-}$. Isso se deve a maior abundância desse ânion em solução em meios ácidos. Porém, à medida que o $\mathrm{pH}$ é aumentado, a formação de complexos com $\mathrm{CO}_{3}$ e $\mathrm{HCO}_{3}$ passa a ser mais importante (Sposito, 1983). Taylor \& Percival (2001) observaram que o Cd encontravase associado, principalmente, com $\mathrm{SO}_{4}{ }^{2-}$ e $\mathrm{CI}$, e que a associação com $\mathrm{NO}_{3}{ }^{-}$e $\mathrm{PO}_{4}{ }^{3-}$ era 
menos importante devido à menor habilidade desses últimos ligantes em complexar o metal. O aumento na força iônica favoreceu a formação de complexos com o $\mathrm{SO}_{4}{ }^{2-}$ para os três metais estudados e redução das formas livres, com exceção do LVwf. Nessa amostra, a porcentagem e Cu-livre foi aumentada no tratamento F.I. em relação ao pH 6. A elevação da força iônica resultou em aumento nas quantidade dos íons $\mathrm{SO}_{4}{ }^{2-}$ e $\mathrm{NO}_{3}{ }^{-}$, favorecendo a formação de complexos com os metais. Ao contrário do observado por Fotovat \& Naidu (1998), o aumento na força iônica da solução não ocasionou maior concentração de carbono orgânico dissolvido (COD).

$\mathrm{O} \mathrm{Cu}$, como esperado, apresentou maior afinidade em formar complexos orgânicos do que o $\mathrm{Zn}$ e o $\mathrm{Cd}$, sobretudo nos valores mais elevados de $\mathrm{pH}$ (Tabela 15). A afinidade do $\mathrm{Cu}$ em formar complexos com ligantes orgânicos em solução foi observada em diversos trabalhos (McBride \& Blasiak, 1979; Sposito, 1983; Ge et al., 2000). No pH 7, cerca de $10 \%$ do Cu estava associado a ligantes orgânicos no LAd. Percival et al. (1999) encontraram valores próximos, ou seja, aproximadamente $10 \%$ do $\mathrm{Cu}$ complexado por ligantes orgânicos. A associação de $\mathrm{Cu}$ com ligantes orgânicos em solução, especificamente com ácidos fúlvicos (CuFA) foi também observada por Ge et al. (2000). No LAd, nos pHs 6 e 7, parte do $\mathrm{Cu}$ foi precipitado na forma de $\mathrm{Cu}(\mathrm{OH})_{2}$, possivelmente pela menor concentração de ligantes orgânicos e de sulfato em relação ao LVwf. $\mathrm{Na}$ ausência de substâncias complexantes, o $\mathrm{Cu}$ em pHs elevados pode ser precipitado na forma de $\mathrm{Cu}(\mathrm{OH})_{2}$ (Cavallaro \& McBride, 1980).

$\mathrm{O}$ aumento dos ligantes em solução e a redução da atividade de $\mathrm{Cu}^{2+}$ pode ser evidenciado quando se comparam as porcentagens do metal livre no $\mathrm{pH} 6$ com o tratamento F.I., que apresentou o mesmo valor de pH. No LVwf, o tratamento F.I. ocasionou uma redução na porcentagem de $\mathrm{Cu}^{2+}$ de 83 para $81 \%$, enquanto no LAd a quantidade do metal livre foi aumentada de 27 para $81 \%$, acompanhado da eliminação do precipitado $\mathrm{Cu}(\mathrm{OH})_{2}$. Corroborando esses resultados, Salam \& Helmke (1998) observaram que a distribuição de $\mathrm{Cu}$ na solução foi mais acentuadamente afetada em relação aos demais metais, quando se compararam solos com diferentes quantidades de ligantes orgânicos. Da mesma forma como ocorreu com o tratamento F.I., à medida que $\mathrm{o} \mathrm{pH}$ foi aumentado, o $\mathrm{Cu}$ tende a estar presente, principalmente, na forma de 
complexos. McBride \& Blasiak (1979) observaram que com o aumento do $\mathrm{pH}$ houve correspondente aumento na concentração de $\mathrm{Cu}$ em solução, porém esse efeito não foi acompanhado por uma elevação na atividade do metal. Esses autores sugeriram que, acima de $\mathrm{pH} 5$, a maior parte do $\mathrm{Cu}^{2+}$ estava complexado. McBride \& Blasiak (1979) encontraram $99 \%$ do $\mathrm{Cu}$ total complexado em $\mathrm{pH}$ 8. Ao contrário do $\mathrm{Zn}$, o $\mathrm{Cu}$ encontrava-se em espécies moderadamente lábeis ou não-lábeis na solução, mesmo quando o solo foi tratado com o metal (Jeffery \& Uren, 1983).

Ao contrário do $\mathrm{Cu}$, o $\mathrm{Zn}$ e o $\mathrm{Cd}$ apresentaram-se na solução, principalmente na forma de íons-livres em ambos os solos. Aproximadamente 81 a $98 \%$ do $\mathrm{Zn}$ total e de 88 a $98 \%$ do Cd total estavam na forma livre em ambos os solos. Lorenz et al. (1997) observaram que a maior parte do $\mathrm{Zn}$ e do $\mathrm{Cd}$ estava presente na forma livre. Candelaria \& Chang (1997) encontraram que a maior parte do Cd estava presente na forma livre em solução (mais do que $50 \%$ do $\mathrm{Cd}$ total), quer o metal fosse adicionado via sal solúvel, quer via biossólido. Isso demonstra que, nas condições estudadas por esses autores, o biossólido não contribuiu no aumento de ligantes orgânicos e inorgânicos para solução que pudessem complexar o metal. Entretanto, Salam \& Helmke (1998) observaram que a adição de biossólidos nos solos promoveu o aumento da quantidade de $\mathrm{Cu}$ e $\mathrm{Cd}$ livres em solução, devido a protonação dos agentes complexantes em pHs inferiores a 5,5. Esse fenômeno pode ter ocorrido no experimento, uma vez que no valor mais baixo de $\mathrm{pH}$ foram encontrados as maiores quantidades de $\mathrm{Cu}, \mathrm{Zn}$ e $\mathrm{Cd}$ livres. Porém, os resultados da distribuição das espécies de $\mathrm{Cd}$ em solução discordam dos obtidos por Sauvé et al. (2000), que estudando 64 solos com atributos contrastantes, observaram que a maior parte do $\mathrm{Cd}$ em solução estava complexado com ligantes orgânicos. Entretanto, esses autores afirmaram que à medida que $\mathrm{o} \mathrm{pH}$ do solo se torna mais baixo, as forma de Cd livre e complexado com ligantes inorgânicos se tornam mais importantes.

Ao contrário do observado por Sauvé et al. (2000), Lorenz et al. (1997) não observaram relação entre o aumento do COD na região da rizosfera e menor quantidade das formas livres de $\mathrm{Zn}$ e $\mathrm{Cd}$. No $\mathrm{pH} 7$, ao redor de 87 a $88 \%$ do $\mathrm{Cd}$ em solução estava presente como íon-livre. Esses valores são superiores aos encontrados por Ge et al. (2000), que estudando solos com pH entre 6,39 a 8,55 encontraram 32 a $60 \%$ do Cd em 
solução na forma livre. Porém, Taylor \& Percival (2001) observaram entre 55 a $90 \%$ do $\mathrm{Cd}$ na forma livre em solos com pHs mais próximos ao dos Latossolos estudados. Essa diferença nos resultados obtidos nesses trabalhos indica que o $\mathrm{pH}$ do solo influenciou marcadamente a quantidade Cd-livre em solução. Contrariando os resultados de Sauvé et al. (2000), que observaram maior formação de complexos entre o $\mathrm{Cd}$ e os ligantes orgânicos em $\mathrm{pH} 6$, a porcentagem desses complexos foi menor do que 0,5 \% no pH 7 e ao redor de $0,15 \%$ no $\mathrm{pH} 6$ em ambos os solos. $\mathrm{O}$ Cd foi o único metal capaz de formar complexos com o $\mathrm{Cl}$, o que se deveu a maior valor da constante de formação de complexos entre Cd e o íon CI $(1,97)$ em relação ao Zn $(0,49)$ e ao Cu $(0,40)$ (Evans et al., 1995). A formação do complexo Cd-cloreto deve ser destacada, uma vez que ele é considerado biodisponível e que a absorção de Cd pela planta é aumentada na presença desse ligante (Sauvé et al., 2000). Esses autores afirmaram que não se sabe se a absorção do metal é favorecida devido à maior difusão do $\mathrm{Cd}$ nas raízes das plantas na presença do cloreto ou se o complexo é, por si só, mais biodisponível em relação às demais complexos em solução. A maior disponibilidade do Cd complexado com CI foi também reportada por Weggler-Beaton et al. (2000), que sugeriram que as formas $\mathrm{CdCl}$ e $\mathrm{CdCl}_{2}{ }^{0}$ são mais móveis e podem difundir-se mais facilmente para a rizosfera.

$\mathrm{Na}$ faixa de $\mathrm{pH}$ estudada, o $\mathrm{Zn}$ foi encontrado sobretudo como íon-livre. McBride \& Blasiak (1979) observaram que, em valores de $\mathrm{pH}$ inferiores a 6,5, o $\mathrm{Zn}$ foi encontrado, principalmente, como íon-livre. Para valores de $\mathrm{pH}$ inferiores a 5, Jeffery \& Uren (1983) encontraram cerca de $99 \%$ do $\mathrm{Zn}$ na forma livre. Nesse mesmo $\mathrm{pH}$, cerca de $96 \%$ do $\mathrm{Zn}$ em solução foi encontrado na forma livre. Embora Kabata-Pendias \& Pendias (1987) afirmem que o aumento do $\mathrm{pH}$ resulte em maior concentração de compostos orgânicos no solo e, conseqüentemente, a associação $\mathrm{Zn}$-complexos orgânicos seja favorecida, apenas 0,88 e $0,35 \%$ do $\mathrm{Zn}$ total estava complexado com ligante orgânicos no pH 7 nas amostras LVwf e LAd, respectivamente. Nesse pH, a formação de $\mathrm{Zn}(\mathrm{OH})^{+}$foi importante. Os resultados discordam dos obtidos por Ge et al (2000), que encontraram aproximadamente $93 \%$ do $\mathrm{Zn}$ associado com ácidos fúlvicos em solução. Essa diferença pode ser devida aos maiores teores de $\mathrm{Zn}$ nos solos estudados por esses autores e ao $\mathrm{pH}$ dos solos ser superior a 7. A menor porcentagem de 
Zn ligado a compostos orgânicos pode ter ocorrido devido às baixas concentrações desses em solução para esses solos. A dissolução do biossólido possivelmente não promoveu aumento significativo na quantidade de COD.

\subsection{Conclusões}

$\mathrm{O}$ pH teve efeito marcante na disponibilização de $\mathrm{Zn}, \mathrm{Cu}$ e $\mathrm{Cd}$ do biossólido e na distribuição dos metais na fase sólida e em solução em ambos os solos. $\mathrm{O} \mathrm{Cu}$ foi menos afetado pela variação do $\mathrm{pH}$ da solução do que o $\mathrm{Zn}$ e o $\mathrm{Cd}$. Os mecanismos nos quais os metais são retidos no biossólido e no solo parecem ser diferenciados, e as respostas às variações no meio, tais como $\mathrm{pH}$ e força iônica da solução, dependem do metal em questão. O aumento na força iônica em dez vezes em relação ao valor original da solução do solo não proporcionou diferenças na quantidade disponiblizada e/ou na distribuição dos metais em ambos os solos. Os resultados apontam para riscos potenciais da aplicação de biossólidos com elevada concentração de metais em solos com pH ácidos, uma vez que esses se encontram, na sua maior parte, em formas móveis e biodisponíveis. 


\section{CONDICIONADORES QUÍMICOS NA RETENÇÃO E DISTRIBUIÇÃO DE METAIS PESADOS EM LATOSSOLOS E EM BIOSSÓLIDO}

\section{Resumo}

A aplicação agrícola de biossólidos é uma das alternativas eficientes de manejo desse resíduo. Porém, dependendo da origem e do sistema de tratamento, os biossólidos podem conter elevadas concentrações de metais pesados, que podem acumular-se nos solos. O uso de condicionadores químicos de solos contaminados por metais pode reduzir a biodisponibilidade e a mobilidade dos metais nos solos e, consequentemente, os riscos ao meio ambiente. O objetivo desse trabalho foi estudar os efeito de condicionadores de solos na retenção e distribuição de $\mathrm{Zn}, \mathrm{Cu}$ e $\mathrm{Cd}$ em Latossolos tratados com biossólidos. Utilizaram-se amostras superficiais $(0-20 \mathrm{~cm})$ de dois solos do Estado de São Paulo: Latossolo Vermelho acriférrico (LVwf) e Latossolo Amarelo distrófico (LAd). Dois gramas de terra foram colocados para reagir nas câmaras-duplas de difusão com $2 \mathrm{~g}$ de biossólido, proveniente de Chicago, EUA. Os condicionadores foram adicionados nas câmaras, e consistiram dos seguintes materiais: a) $\mathrm{CaCO}_{3}$; b) $\mathrm{KH}_{2} \mathrm{PO}_{4}$; c) hidroxiapatita sintética (HA) nos $\mathrm{pHs} 4,5$ e 6; e d) $\mathrm{CaSO}_{4}$. Após o equilíbrio nas câmaras, a solução foi centrifugada, filtrada e acidificada. A fase sólida (solo e biossólido) foi seca e procedeu-se a extração seqüencial de $\mathrm{Zn}, \mathrm{Cu}$ e $\mathrm{Cd}$. Os condicionadores testados foram eficientes na remoção de $\mathrm{Zn}, \mathrm{Cd}$ e, em menor proporção,

$\mathrm{Cu}$ da solução. Em geral, o $\mathrm{CaCO}_{3}$ foi o mais eficiente na imobilização dos metais, seguido da HA (pH6). O pH teve efeito marcante no comportamento desses materiais. A 
HA foi totalmente dissolvida nos $\mathrm{pHs}$ testados, porém a eficiência na imobilização dos metais foi mais acentuada no $\mathrm{pH}$ 6. A quantidade de metais ligados à fração trocável foi sensivelmente reduzida, e os metais ligados à superfície dos óxidos/carbonatos foram aumentados com a introdução dos condicionadores no solo, principalmente nos pHs mais elevados. Entretanto, essa fração pode ser facilmente solubilizada com a acidificação do meio, e os metais associados à ela podem ser novamente disponiblizados para solução.

\section{Summary: AMENDEMENTS AND HEAVY METAL RETENTION AND DISTRIBUITION IN OXISOLS AND BIOSOLID}

Land application of biosolids in agricultural areas is an efficient alternative for

their use. However, depending on the origin and the treatment system, biosolids might have high contents of heavy metals, which may accumulate in soils. The use of amendments in contaminated areas may reduce the bioavailability and the mobility of heavy metals in soils and, consequently, the risks to the environment. The objective of this work was to study the effect of amendments in the $\mathrm{Zn}, \mathrm{Cu}$ and $\mathrm{Cd}$ retention and distribution in Oxisols treated with biosolids. Surface soil samples $(0-20 \mathrm{~cm})$ from a Rhodic Acrudox (RA) and a Typic Haplorthox (HP) were used. Two grams of each soil sample were equilibrated in a dual-chamber diffusion with $2 \mathrm{~g}$ of biosolid from Sewage Sludge Treatment Facility from Chicago, USA. The amendments were: a) $\mathrm{CaCO}_{3}$, b) $\mathrm{KH}_{2} \mathrm{PO}_{4}$, c) synthetic hydroxyapatita (HP) at $\mathrm{pHs} 4,5$ e 6, d) $\mathrm{CaSO}_{4}$. After equilibrium, the solution was centrifuged, filtered and acidified. The solid phase (soil and biosolid) was dried and the sequential extraction of $\mathrm{Zn}, \mathrm{Cu}$ and $\mathrm{Cd}$ was performed. The amendments were efficient in immobilizing $\mathrm{Zn}$ and $\mathrm{Cd}$, and in smaller proportion. The effect was less pronounced for $\mathrm{Cu}$. Generally, the $\mathrm{CaCO}_{3}$ removed higher amounts of metals in solution, followed by the HA ( $\mathrm{pH} \mathrm{6).} \mathrm{The} \mathrm{pH}$ influenced the efficiency of the amendments. The HP was completely dissolved at the tested $\mathrm{pHs}$, however, the metal immobilization was higher at $\mathrm{pH}$ 6. The amendments reduced markedly the metals associated with the exchangeable fraction, and increased the surface oxides/carbonate 
fraction, especially at high $\mathrm{pH}$ values. However, this fraction may be easily dissolved with the acidification, and the metals may be readily available.

\subsection{Introdução}

O acúmulo de metais pesados em solos agrícolas tem se tornado um problema ambiental crítico nos últimos anos. Os metais podem ser introduzidos nos solos devido à deposição atmosférica, aplicação de fertilizantes, esterco animal, pesticidas e resíduos provenientes de estações de tratamento de água e esgoto. As quantidades de resíduos produzidas diariamente exigem que sejam adotadas alternativas de uso desses materiais, visando à proteção ao meio ambiente. Com relação ao resíduo resultante do tratamento de esgoto, também referido como biossólido, no Brasil atualmente são tratados $35 \%$ do esgoto coletado, ou seja, aproximadamente 1,8 milhões de $\mathrm{m}^{3} / \mathrm{dia}$ (Brasil..., 2002). Nos últimos quatro anos, esse número vem crescendo, porém a tendência é aumentar ainda mais, uma vez que apenas $42 \%$ da população brasileira possuem rede coletora de esgoto. O manejo e a disposição do biossólido, levando em consideração aspectos econômicos e ambientais, é atualmente um dos maiores problemas das sociedades industrializadas (Oberle \& Keeney, 1994). Uma das alternativas para o uso desse resíduo é o uso agrícola. Na China, por exemplo, são produzidos $2 \times 10^{5}$ milhões de toneladas (base seca) de biossólido por ano, com um crescimento anual de $20 \%$, e a aplicação em áreas agrícolas tem se tornado uma alternativa viável para uso desse resíduo (Wong \& Fang, 2000). Na França, dos 900 milhões toneladas de biossólido produzidos anualmente, cerca de 60 \% são reciclados em áreas agrícolas (Maisonnave et al., 2001). Na Comunidade Européia, $60 \%$ do biossólido produzido é aplicado na agricultura, o que significa quantidades ao redor de 750 mil toneladas (base seca) ou aproximadamente 18 milhões de toneladas (base úmida) (McGrath, 1987). Porém, os riscos a longo prazo devido ao uso agrícola de biossólidos são desconhecidos (Maisonnave et al., 2001).

Quando aplicados em área agrícola, os biossólidos podem influenciar os processos químicos, físicos e biológicos nos solos, alterando a relação solo-água-planta (Oberle \& Keeney, 1994). Os biossólidos podem promover a melhoria de alguns 
atributos químicos do solo, tais como $\mathrm{pH}$, teores de matéria orgânica, nitrogênio, fósforo disponível, além de fornecer nutrientes às culturas (Tsadilas et al., 1995; LópezMosquera et al., 2000; Sastre et al., 2001). A porosidade, estabilidade de agregados, densidade, movimento e retenção de água também são favorecidos (Karapanagiotis et al., 1991). Porém, dependendo da origem e do sistema de tratamento do biossólido, seu uso pode ser limitado devido às concentrações de metais pesados presentes nesse resíduo. O uso contínuo de biossólidos contendo metais pesados pode levar ao acúmulo nos solos agrícolas. A concentração de metais nos biossólidos depende de diversos fatores, como a fonte do resíduo, do sistema de tratamento, do período no qual o material é digerido e estabilizado e de como o material é transportado e aplicado ao solo (Orbele \& Keeney, 1994). Um aumento gradual na concentração total e/ou disponível de elementos traços tem sido reportada nas últimas décadas em países industrializados (Kabata-Pendias \& Pendias, 1987; McBride \& Spiers, 2001). Esse acúmulo, embora lento, pode causar em problemas sérios na fertilidade do solo, na qualidade das águas de subsuperfície e na cadeia alimentar (Keller et al., 2001). Embora os solos atuem na regulação e controle do transporte de elementos químicos em vários compartimentos do ecossistema, a persistência dos contaminantes no solo, especialmente os metais pesados, é mais longa do que nos outros componentes da biosfera (Kabata-Pendias \& Pendias, 1987).

Os limites para aplicação de metais pesados aos solos ainda parece ser controverso, uma vez que, dependendo dos país, as regras são mais permissivas. Por exemplo, o limite máximo de metais presentes no biossólido permitido pela Comunidade Européia, em mg kg-1, é de até 40 de Cd, 400 de Ni, 1000 de Pb, 3000 de Zn e 1500 de Cu. Em contrapartida, a legislação americana (EPA 503) (Estados Unidos, 1993) e a brasileira promulgada pela companhia de tecnologia de saneamento ambiental CETESB (norma P 4.230) (CETESB, 1999) permitem, em mg kg Cd, 420 de Ni, 840 de $\mathrm{Pb}, 7500$ de Zn e 4300 de Cu. Nota-se que, para alguns metais, os limites são contraditórios. Para Zn, por exemplo, a EPA-503 e a P 4.230 permitem uma concentração desse metal no lodo 2,5 vezes superior à da norma da Comunidade Européia. Não existem conclusões definitivas sobre os riscos do uso de biossólidos na 
agricultura, os efeitos dessa prática a longo prazo e os resultados das alterações dos atributos do solo, tal como o pH e a mineralização da matéria orgânica. (McBride, 1995, 1997; Chang et al., 1997).

Nos solos, a mobilidade dos metais pesados adicionados via biossólido depende da dinâmica da água no perfil do solo e da interação química dos metais pesados com a fase sólida do solo, por meio das reações de sorção/desorção, precipitação/dissolução e complexação (Cornu et al., 2001). Além desses fatores, o pH, a concentração iônica da solução do solo e a presença de ligantes orgânicos e inorgânicos pode influenciar a disponibilidade de metais às plantas (Ross, 1994). Os metais são geralmente menos solúveis em altos valores de pH ou em estado de oxidação mas elevado (Ross, 1994).

As reações de precipitação/dissolução e os mecanismos de adsorção/dessorção são os principais processos físico-químicos que controlam as concentrações de espécies metálicas na solução do solo (Ross, 1994). As reações de adsorção, em particular, controlam a mobilidade e a biodisponibilidade de metais pesados nos solos e representam um importante mecanismo regulador do ciclo geoquímico desses elementos no ecossistema. $\mathrm{Na}$ solução do solo, os metais-traços, como o $\mathrm{Cd}, \mathrm{Pb}$ e $\mathrm{Cu}$, tem que competir pelos sítios de troca com cátions presentes em maior abundância na solução, como o $\mathrm{Ca}$ e $\mathrm{Na}$, e/ou podem ser adsorvido especificamente (Ross, 1994). Os principais componentes do solo envolvidos na adsorção de metais pesados são as formas hidratadas dos óxidos de Fe e Mn, a matéria orgânica e os minerais de argila (Kabata-Pendias \& Pendias, 1987). Nesse processo estão envolvidas forças físicas (van der Waals e ligações eletrostáticas) e químicas (complexos de esfera interna) (Sparks, 1995). Em geral, Cd e $\mathrm{Zn}$ tendem a ser mais móveis no solo do que o $\mathrm{Pb}$ e o $\mathrm{Cu}$, pois os primeiros são retidos, principalmente, por forças eletrostáticas, e sofrem influencia da competição dos íons em solução, incluindo o $\mathrm{H}^{+}$(Ross, 1994). Embora seja difícil de distinguir experimentalmente qual processo é predominante, sabe-se que a interação entre o metal e a fase sólida depende de diversos fatores, dentre eles da quantidade e do tipo de sítios associados com a fase sólida do solo, da concentração do metal e dos ligantes capazes de formar complexos organo-minerais, do $\mathrm{pH}$, da condutividade elétrica e do potencial 
redox do solo (Kiekens, 1983). Porém, o $\mathrm{pH}$ do solo parece ser o principal fator controlando a solubilidade e a adsorção dos metais no solo (Ross, 1994).

A remediação de solos contaminados por metais pesados, envolvendo processos de escavação e remoção do material contaminado, embora possa ser a melhor opção em alguns casos, pode não ser viável em vastas áreas poluídas (Boisson et al., 1999). A escavação, além de onerosa, resulta em outro problema, ou seja, a alocação do material poluído (Pearson et al., 2000). Estima-se que os custos das técnicas de remediação, destinadas às áreas de mineração, agrícolas e industriais, excedam um milhão de dólares apenas nos Estados Unidos. Porém, muitas das técnicas empregadas nesse país com o objetivo de reduzir os níveis dos metais para teores aceitáveis pela legislação não foram bem sucedidas, pois cada metal exibe uma solubilidade e propriedades de sorção características em determinadas condições ambientais.

Uma alternativa economicamente mais adequada é a remediação in situ, promovendo a estabilização e reduzindo os riscos de contaminação do lençol freático (Boisson et al., 1999). Nesse processo podem ser utilizados microrganismos (bioremediação), plantas com características específicas (fitoremediação) ou compostos químicos (condicionadores de solos). Diversos materiais têm sido utilizados nos últimos anos como condicionadores de solos contaminados por metais pesados, dentre eles calcário, gesso agrícola, hidroxiapatita e outras fontes solúveis de $\mathrm{P}$, materiais ricos em Fe ou Mn, e argilas (Boisson et al., 2001; Hamon et al., 2002). Calcário, fosfatos e matéria orgânica estabilizam os metais por meio de ligações químicas, e o resultado é a formação de novos compostos estáveis, menos móveis ou tóxicos, prevenindo a sua lixiviação para o lençol freático ou para outros compartimentos do ecossistema (KabataPendias \& Pendias, 1987). Os condicionadores de solos contaminados atuam no solo alterando o pH da solução ou formando ligações com os metais em formas não prontamente disponíveis (Hamon et al., 2002). Os metais mais eficientemente estabilizados em fases insolúveis no solo são o chumbo, zinco, cobre, cádmio, níquel, urânio e bário.

Uma das técnicas para redução da disponiblidade de metais pesados no solo é o uso de $\mathrm{CaCO}_{3}$ ou calcário. $\mathrm{O}$ carbonato de cálcio promove a elevação do $\mathrm{pH}$ do solo e, 
conseqüentemente, a redução na mobilidade de metais, uma vez que esses tendem a estar em formas mais solúveis em ambientes ácidos. A elevação do $\mathrm{pH}$ do solo é apontada como um dos principais fatores associados à redução das frações biodisponíveis de metais em solos tratados com biossólidos (Wong \& Fang, 2000). Shuman (1986), estudando solos arenosos tratados com calcário, encontrou sintomas de deficiência de micronutrientes nas plantas, principalmente $\mathrm{Zn}$ e $\mathrm{Mn}$, e redução nos teores trocáveis desses metais. Porém, a aplicação de calcário, embora promova a elevação do $\mathrm{pH}$, pode não resultar na imobilização de alguns metais presentes no solo como quelatos orgânicos (Kabata-Pendias \& Pendias, 1987). Além da redução na disponibilidade dos metais, em valores mais elevados de $\mathrm{pH}$ ocorre a desprotonação dos colóides dos solos com cargas variáveis e a redução na competição dos íons $H^{\dagger}$ pelos sítios de carga, favorecendo a adsorção de metais (Impellitteri et al., 2001). Em áreas poluídas por metais e tratadas com calcário, o pH deve ser continuamente monitorado para evitar os riscos de contaminação das plantas (Hamon et al., 2002). O princípio de imobilizar os metais pesados em pHs elevados pode ser utilizado no processo de tratamento dos biossólidos (Fang \& Wong, 1997; Wong \& Fang, 2000). Nesse caso, utilizam-se materiais alcalinos como a cal virgem ou hidratada, calcário e cinzas para diminuição na quantidade de metais trocáveis no biossólido. Fang \& Wong (1997) encontraram que o tratamento de biossólidos com calcário reduziu os teores de $\mathrm{Cu}$ e Mn trocáveis de forma mais evidente do que para $\mathrm{Ni}, \mathrm{Pb}$ e $\mathrm{Zn}$, porém os teores totais dos metais não foram alterados. Outra vantagem do aumento do $\mathrm{pH}$ no processo de tratamento de biossólidos é o controle de microrganismos patogênicos nesse material. Porém, o efeito do uso de calcário em solos contaminados pode ser efêmero, uma vez que a posterior acidificação pode tornar os metais disponíveis novamente (Hamon et al., 2002).

Diversas fontes de $\mathrm{P}$ são utilizadas para reduzir a disponibilidade de metais em solos (Xu \& Schwartz, 1994; Ma et al., 1995; Pearson, et al., 2000). Pearson et al. (2000) utilizaram $\mathrm{KH}_{2} \mathrm{PO}_{4}$ como fonte de $\mathrm{P}$, com o objetivo de reduzir a disponibilidade de $\mathrm{Pb}, \mathrm{Zn}$ e $\mathrm{Cd}$ para minhocas (E. fetida). O mecanismo no qual o $\mathrm{P}$ reduz a disponibilidade de metais, sobretudo $\mathrm{Pb}$, é devido a formação de piromorfitas $\left(\mathrm{Pb}_{5}\left(\mathrm{PO}_{4}\right)_{3} \mathrm{X}\right)$, no qual $\mathrm{X}$ pode ser $\mathrm{OH}, \mathrm{Cl}$ ou $\mathrm{F}$. 
A hidroxiapatita, $\left(\mathrm{Ca}_{10}\left(\mathrm{PO}_{4}\right)_{6}(\mathrm{OH})_{2}\right)$, outra fonte de $\mathrm{P}$, é também utilizada na remediação de solos contaminados por metais (Xu \& Schwartz, 1994; Ma et al., 1995; Boisson et al., 1999). A hidroxiapatita é um mineral encontrado em solos, sedimentos, partículas suspensas e no corpo humano. As formas desse mineral no corpo humano, principalmente nos dentes e ossos, são responsáveis pelo controle ou redução dos níveis de metais pesados, tais como o Zn e Cd no organismo (Xu \& Schwartz, 1994). Alguns metais, como o chumbo, podem entrar na estrutura mineral da apatita durante a formação da nova fase sólida, por exemplo, chumbo-apatita, ou apenas deslocar o cálcio da superfície desse mineral. Devido a estabilidade da apatita em diversas condições ambientais (pHs entre 2 a 12), os metais sequiestrados no interior do mineral apresentam longa durabilidade e resistência quando comparados a outros estabilizadores químicos. Outra vantagem desse tratamento é que a reação entre a apatita e os metais é rápida (Ma et al., 1993) e apenas $1 \%$ desse material (em base de massa) pode ser capaz de remediar solos extremamente contaminados por metais. Embora existam diversas fontes naturais de apatita, com diferentes propriedades de reatividade, nem todas são recomendáveis para uso como condicionador de solos contaminados. Alguns dos requisitos para esse mineral ser utilizado são: a) apresentar os sítios de substituição totalmente preenchidos com carbonatos, b) não apresentar substituição de fluoreto na posição das hidroxilas, c) não ser contaminado com metais pesados inicialmente na sua estrutura, d) apresentar elevada porosidade interna

Diversos autores utilizaram a hidroxiapatita como condicionador de solos contaminados por metais. Boisson et al. (1999) encontraram redução nas concentrações de $\mathrm{Cd}, \mathrm{Pb}, \mathrm{Cu}$ e $\mathrm{Zn}$ extraídas com $0,1 \mathrm{~mol} \mathrm{~L}^{-1}$ de $\mathrm{Ca}\left(\mathrm{NO}_{3}\right)$ em solos contaminados por metais e tratados com hidroxiapatita. Alguns mecanismos foram propostos por Ma et al. (1994) e Xu \& Schwartz (1994) para explicar a redução nas formas solúveis de metais quando tratados com hidroxiapatita, dentre eles: a) processo de troca iônica na superfície da hidroxiapatita; 2) complexação dos metais; 3) precipitação de formas amorfas ou pouco cristalinas. Porém, esses processos ocorrem concomitantemente e é difícil distinguir o predominante (Xu \& Schwartz, 1994). Dependendo do metal, essa interação pode promover a formação de um mineral mais estável do que a hidroxiapatita, tal como 
ocorre com o $\mathrm{Pb}$, resultando na precipitação de piromorfitas ( $\mathrm{Pb}$-apatita). Ma et al. (1995) sugeriram que a interação entre $\mathrm{Pb}$ e $\mathrm{P}$ nos solos pode resultar na precipitação de hidroxipiromorfita, cloropiromorfita ou fluorpiromorfita e que esse mecanismo foi importante no controle da solubilidade e biodisponibilidade de $\mathrm{Pb}$ na água, no solo e em resíduos. A cloropiromorfita $\left(\mathrm{Pb}_{5}\left(\mathrm{PO}_{4}\right)_{3} \mathrm{Cl}\right)$ é considerada a forma mais estável e eficiente em "sequiestrar" Pb em solos (Pearson et al., 2000). Xu \& Schwartz (1994) observaram que a hidroxiapatita foi capaz de remover mais do que $99 \%$ do $\mathrm{Zn}$ e do $\mathrm{Cd}$ presente numa solução com pH variando de 5,64 a 7,22. A adição de hidroxiapatita nos solos promove a elevação nos valores de $\mathrm{pH}$, favorecendo a imobilização dos metais (Boisson et al., 1999). Porém, Xu \& Schwartz (1994) observaram que a adsorção de Zn e Cd na superfície da hidroxiapatita resultou na produção de prótons, confirmando que não apenas mecanismos de troca iônica estavam envolvidos na retenção desses metais. Boisson et al. (1999) encontram uma desvantagem no uso de hidroxiapatita em solos contaminados. Esses autores observaram maior produção de matéria seca de plantas de milho e feijão em solos tratados com hidroxiapatita quando comparadas a cultivos sem tratamento, porém em doses elevadas de hidroxiapatita, os níveis de As no tecido foliar foram aumentados. Esse efeito foi devido a interação competitiva entre $\mathrm{o}^{\mathrm{PO}_{4}}$ da hidroxiapatita e $\mathrm{o}^{\mathrm{AsO}_{4}}$ presente no solo pelos sítios de adsorção. Outras rochas fosfatadas, tal como a fluorapatita, podem ser utilizadas na imobilização de metais em solos contaminados. Ma et al. (1995) demonstraram que rochas fosfáticas foram capazes de reduzir o 38-100 \% do $\mathrm{Pb}$ em solução e que, quanto maior a solubilidade desse material, maior foi a redução de $\mathrm{Pb}$ na solução. Esses autores sugeriram que em concentrações semelhantes de $\mathrm{PO}_{4}{ }^{3-}, \mathrm{CO}_{3}{ }^{2-}$ e $\mathrm{OH}^{-}$o mecanismo de precipitação de $\mathrm{Pb}$ pode ser descrito como:

$$
\begin{aligned}
& \mathrm{Ca}_{10}\left(\mathrm{PO}_{4}\right)_{3}\left(\mathrm{CO}_{3}\right)_{3} \mathrm{FOH}(\mathrm{s})+6 \mathrm{H}^{+} \stackrel{\text { dissolução }}{\longrightarrow} 10 \mathrm{Ca}^{2+}+3 \mathrm{H}_{2} \mathrm{PO}_{4}{ }^{-}+3 \mathrm{CO}_{3}{ }^{2-}+\mathrm{F}^{-}+\mathrm{OH}^{-} \\
& 10 \mathrm{~Pb}^{2+}+3 \mathrm{H}_{2} \mathrm{PO}_{4}^{-}+3 \mathrm{CO}_{3}{ }^{2-}+\mathrm{F}^{-}+\mathrm{OH}^{-} \stackrel{\text { precipitação }}{\longrightarrow} \mathrm{Pb}_{10}\left(\mathrm{PO}_{4}\right)_{3}\left(\mathrm{CO}_{3}\right)_{3} \mathrm{FOH}(\mathrm{s})+6 \mathrm{H}^{+}
\end{aligned}
$$


Baseado nessas equações, Ma et al. (1995) concluíram que a hidroxiapatita, por ser mais solúvel e, conseqüentemente, fornecer mais $\mathrm{P}$ para precipitar com $\mathrm{Pb}$, foi mais eficiente que as demais rochas fosfáticas estudadas por esses autores.

Embora não existam muitos trabalhos publicados a esse respeito, o gesso agrícola $\left(\mathrm{CaSO}_{4} \cdot 2 \mathrm{H}_{2} \mathrm{O}\right)$ pode ser utilizado como condicionador em áreas contaminadas por metais. Normalmente o gesso é utilizado em solos ácidos, como os Ultisols e Oxisols, com o objetivo de reduzir os efeitos tóxicos do Al livre na solução. Em geral, o gesso não altera o $\mathrm{pH}$ do solo mais do que 0,3 unidade (Sposito, 1989). Peacock \& Rimmer (2000), utilizando gesso conhecido como gesso-vermelho, o qual difere do gesso puro branco apenas devido ao $\mathrm{pH}$ mais elevado no qual é precipitado, obtiveram que a afinidade de adsorção desse material foi: $\mathrm{Pb}>\mathrm{Zn}>\mathrm{Cd}>\mathrm{Cu}>\mathrm{Ni}$. Esses autores sugeriram que esse material poderia ser utilizado como condicionador em áreas contaminadas por metais, principalmente por $\mathrm{Pb}$.

A principal limitação das técnicas de remediação é o desconhecimento se estes mecanismos são reversíveis com o tempo (Hamon et al., 2002). Por exemplo, em áreas tratadas com calcário ainda é incerto o efeito da posterior reacidificação do solo. Mudanças nas condições de oxidação no solo para ambientes nos quais as reações de redução são predominantes, podem levar à dissolução de componentes importantes na retenção de metais, tais como os óxidos de $\mathrm{Fe}$ e $\mathrm{Mn}$, resultando numa remobilização e liberação dos metais para solução (Davranche \& Bollinger, 2000). Outra crítica que deve ser apontada é que, embora existam diversos trabalhos sobre o uso de condicionadores em solos contaminados por metais pesados, a maioria deles foi desenvolvida para solos de clima temperado. Nos solos tropicais, que exibem pHs baixos $(\leq 5)$, além de reduzido teor de nutrientes, em especial P, e matéria orgânica, além de elevados conteúdos de óxidos de $\mathrm{Fe}$, a resposta desses materiais com relação a mobilidade e disponibilidade de metais pesados pode ser diferenciada. Nos Latossolos, por exemplo, os óxidos e hidróxidos de $\mathrm{Fe}$ influenciam nas características adsortivas desses solos e, conseqüentemente, na retenção de metais (Silveira et al., 2002).

Paralelamente, sabe-se que o teor total dos metais pesados no solo não reflete sua biodisponibilidade. A importância do impacto dos metais pesados no ambiente é 
determinado pela forma e reatividade desses elementos na solução do solo e em equilíbrio com a fase sólida (Krishnamurti \& Naidu, 2002). Em geral, as espécies de metais mais móveis nos solos correspondem às mais disponíveis às plantas, porém essa relação pode ser válida apenas para alguns metais no solo (Ross, 1994). Os diversos procedimentos para realizar a extração seqüencial de metais nas frações da fase sólida, de modo geral, utilizam reagentes para acessar os metais ligados às frações solúvel, trocável, ligado aos carbonatos ou às superfícies dos óxidos, matéria orgânica, facilmente redutível (associado aos óxidos de $\mathrm{Mn}$ ), moderadamente redutível (associada aos óxidos de $\mathrm{Fe}$ ) e residual. Um dos procedimentos utilizados mais freqüentemente é o proposto por Tessier et al. (1979).

Uma das vantagens da extração seqüencial é identificar os principais atributos do solo importantes na retenção de metais, bem como analisar a alteração na distribuição dos metais nos solos em resposta às mudanças no meio, tal como a redução do pH e/ou a utilização de condicionadores de solo. Shuman (1986) destacou a importância de se conhecer a distribuição de micronutrientes nas frações do solo em função do $\mathrm{pH}$, uma vez que esse parâmetro influencia direta e indiretamente a disponibilidade dos mesmos. Ainda, as características adsortivas dos solos com cargas variáveis podem ser alteradas devido à utilização de fontes de $\mathrm{P}$ para remediação de áreas contaminadas. Por exemplo, as quantidades de metais solúveis e trocáveis podem ser diminuídas devido ao aumento na adsorção de metais na superfície dos óxidos de Fe após o equilíbrio com o P.

O objetivo desse trabalho foi avaliar o efeito da utilização de condicionadores de

solos na retenção e distribuição de $\mathrm{Zn}, \mathrm{Cu}$ e $\mathrm{Cd}$ em Latossolos equilibrados com biossólido.

\subsection{Material e Métodos}

Utilizaram-se amostras superficiais $(0-20 \mathrm{~cm})$ de dois solos do Estado de São Paulo: Latossolo Vermelho acriférrico (LVwf) e Latossolo Amarelo distrófico (LAd). Os solos foram escolhidos com base nas diferenças nos teores de argila e de óxidos de Fe. Destaca-se a importância econômica desses solos, uma vez que são intensamente 
cultivados com a cultura da cana-de-açúcar no Estado de São Paulo. O biossólido utilizado foi proveniente da estação de tratamento da cidade de Chicago, EUA, coletado em 1974, e apresenta teores elevados de metais, sobretudo Zn.

Após a coleta, as amostras de terra e biossólido foram secas ao ar, moídas em mortar de ágata e peneiradas em peneiras de 100 mesh. Aproximadamente 0,250 g de terra e 0,100 g de biossólido foram pesados e procedeu-se a digestão completa da amostra em microondas, utilizando o método EPA $3052\left(\mathrm{HNO}_{3}, \mathrm{HF}\right.$ e água deionizada) (Estados Unidos, 1996). No caso da amostra de biossólido, antes da adição do ácido nítrico, adicionou-se $1 \mathrm{~mL}$ de $\mathrm{H}_{2} \mathrm{O}_{2} 30 \%$ para solubilizar o material orgânico. A concentração de metais nas amostras de terra e de biossólido está apresentado na Tabela 12 (capítulo 4).

As amostras de terra e de biossólido foram equilibradas, utilizando o aparato experimental designado como câmaras-duplas de difusão (CDD), modificado de De Pinto (1982), que consiste de duas unidades de policarbonato separadas por uma membrana diâmetro 0,45 $\mu \mathrm{m}$ (Figuras 9 a 11). Em uma das unidades da câmara foram adicionados o equivalente a $2 \mathrm{~g}$ da amostra de terra e, na outra, $2 \mathrm{~g}$ de biossólido. $\mathrm{O}$ experimento foi conduzido como descrito no capítulo 4.

Foram testados os seguintes condicionadores de solo: a) $\mathrm{CaCO}_{3}$, b) $\mathrm{KH}_{2} \mathrm{PO}_{4}$, c) hidroxiapatita sintética (HA), d) $\mathrm{CaSO}_{4}$. As doses utilizadas foram de aproximadamente $1 \%$ (em peso) para o $\mathrm{CaCO}_{3}$, para o $\mathrm{CaSO}_{4}$ e para a $\mathrm{HA}$. A quantidade de $\mathrm{KH}_{2} \mathrm{PO}_{4}$ adicionada foi baseada na porcentagem de $\mathrm{P}$ presente nos tratamentos com HA. Devido à baixa solubilidade, a HA foi equilibrada em três valores de $\mathrm{pH}(4,5$ e 6), para verificar o efeito da sua dissolução na retenção e distribuição de metais nos solos. Paralelamente, o $\mathrm{KH}_{2} \mathrm{PO}_{4}$ foi escolhido por ser uma fonte de $\mathrm{P}$ mais solúvel. Um conjunto testemunha, foi conduzido paralelamente, composto apenas pelo solo e o biossólido equilibrados sem adição dos condicionadores.

Uma vez que as quantidades de HA utilizadas em áreas contaminadas não são bem definidas na literatura, foram testadas as doses de $1 \%$ e $2 \%$ (base massa) de HA na unidade da câmara que continha a amostra de terra e, num terceiro tratamento foi aplicado $1 \%$ de HA em cada um das unidades da câmara (terra e lodo). A quantidade de 
Zn em solução foi utilizada como indicativo da eficiência da dose aplicada. As hipóteses dessa etapa do estudo foram: a) a HA pode influenciar a dissolução do biossólido (eq. 6); b) a HA pode reduzir a quantidade do metal em solução devido à precipitação de nova fase sólida e/ou reações de troca com entre o metal e o $\mathrm{Ca}$ da superfície desse material (eq. 7); c) a HA pode favorecer a adsorção do metal no solo (eq.8).

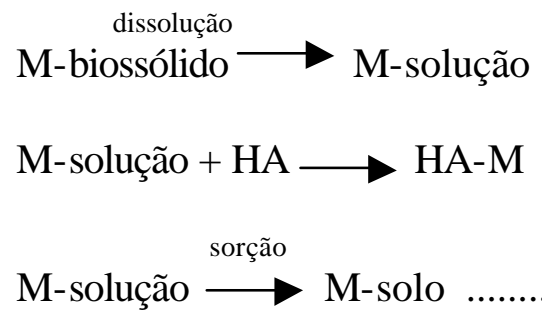

Baseado na composição da solução eletrolítica utilizada nas câmaras, foram calculadas as quantidades de hidroxiapatita solubilizadas nos valores de $\mathrm{pH} 4,5$ e 6, com auxílio do programa de especiação iônica Visual Minteq. Esse programa foi escolhido devido à possibilidade da inclusão da hidroxiapatita (sólida) no cálculo da especiação.

Após atingir o equilíbrio, as câmaras foram desmontadas, as amostras de terra e biossólido foram secas por meio de congelamento e em seguida separaram-se duas subamostras uma delas para realizar a digestão completa e a outra para proceder a extração sequiencial detalhado na Tabela 13 do capítulo 4. A solução das câmaras foi centrifugada a $3500 \mathrm{rpm}$ por 10 minutos e filtrada em papel de filtro Whatman \#42 e, posteriormente acidificada a $1 \%$ com $\mathrm{HNO}$. As leituras de $\mathrm{Zn}$ e $\mathrm{Cu}$ foram realizadas no espectrofotômetro de absorção atômica e o $\mathrm{Cd}$ foi determinado com auxílio do forno de grafite.

No preparo das soluções foi utilizada água deionizada-destilada e os reagentes foram livres de impurezas (trace metal grade). Todas as vidrarias foram mergulhadas em solução de $\mathrm{HNO}_{3} 2 \mathrm{~mol} \mathrm{~L}^{-1}$ por pelo menos 16 horas antes da utilização. 


\subsection{Resultados e Discussão}

\subsubsection{Efeito da dose de HA e do modo de tratamento das amostras}

O aumento na dose de HA de $1 \%$ para $2 \%$ não resultou em uma redução na concentração de Zn em solução (Tabela 16). Boisson et al. (1999) encontraram que doses até $1 \%$ de HA foram eficientes na imobilização de metais em solos contaminados e que doses superiores (até $5 \%$ de HA) promoviam a redução no crescimento das plantas devido à deficiência de nutrientes. Não foi observado efeito do modo de aplicação da HA nesse experimento, ou seja, metade da dose em cada um dos lados da câmara, pois as quantidades de $\mathrm{Zn}$ disponibilizadas pelo biossólido que continha HA foram semelhantes às do tratamento em que a HA foi aplicada apenas no lado do solo. Isso foi um indicativo que, ras doses utilizadas, a HA não promoveu maior adsorção de Zn nos solos e/ou houve menor dissolução desse metal no biossólido. No LVwf, cerca de 81 a $83 \%$ do Zn total ficou retido no biossólido após os tratamentos com HA, enquanto no LAd, esse valor foi ao redor de 95-96 \%. Essa diferença pode ser devida a maior habilidade do LVwf em adsorver o metal e, conseqüentemente, deslocar o equilíbrio da reação de dissolução do biossólido para a fase líquida (eq. 6). A maior capacidade adsortiva do LVwf em relação ao LAd se deve, possivelmente, aos maiores conteúdos de argila (Tabela 4) e de óxidos de Fe exibidos (Tabela 5) no primeiro solo. Baseado nesses resultados, nos ensaios posteriores optou-se pela dose de HA de $1 \%$ (base massa) e a aplicação da HA na unidade da câmara que continha o solo.

\subsubsection{Efeito do pH na quantidade de HA dissolvida}

Nos três valores de pHs estudados a hidroxiapatita foi completamente dissolvida em solução, uma vez que o índice de saturação, calculado pelo Visual Minteq, foi negativo nos três valores de $\mathrm{pH}$. Xu \& Schwartz (1994) observaram índice de saturação negativo em soluções contendo HA e metais. Porém, na ausência dos metais, a solução 
Tabela 16. Quantidade de $\mathrm{Zn}$, em $\mu \mathrm{g}$, nas amostras de terra tratadas com hidroxiapatita (HA), após o equilíbrio com o biossólido

\begin{tabular}{lcccc}
\hline Tratamento & \multicolumn{2}{c}{ LVwf } & \multicolumn{2}{c}{ LAd } \\
\hline & Solo* & Solução** & Solo & Solução \\
$1 \%$ HA & 545 & 222 & 96 & 83 \\
$2 \%$ HA & 525 & 181 & 78 & 91 \\
$2 \%$ HA & 512 & 165 & 88 & 83 \\
$(1 / 2$ solo + 1/Biossólido $)$ & & & & \\
\hline
\end{tabular}

* quantidade de Zn no solo refere-se a 2 g do material; ** quantidade em solução referese a um volume de $500 \mathrm{~mL}$.

de $\mathrm{HA}$ contendo cerca de $0,5 \mathrm{~g}$ de $\mathrm{HA}$ em $150 \mathrm{~mL}$ de $\mathrm{KNO}_{3}\left(0,1 \mathrm{mo} \mathrm{L}{ }^{-1}\right)$ estava saturada. O mesmo não foi observado nesse trabalho, possivelmente pela maior relação entre HA e solução empregada. Ma et al. (1993) observaram que a variação do pH da solução, numa faixa de 3 a 7, resultou em maior dissolução da HA e, conseqüentemente maior quantidade de $\mathrm{P}$ em solução. A diferença nos resultados pode ser devido às maiores quantidades de HA utilizadas por Ma et al. (1993) $(0,2 \mathrm{~g}$ de HA em $150 \mathrm{~mL}$ de solução).

A distribuição das espécies iônicas foi semelhante nos três valores de pH (Tabela $17)$.

Tabela 17. Especiação química da solução eletrolítica após a adição da hidroxiapatita.

\begin{tabular}{ll}
\hline Íons & Espécies químicas \\
\hline $\mathrm{Ca}^{2+}$ & $86 \% \mathrm{Ca}^{2+}, 13 \% \mathrm{CaSO}_{4}(\mathrm{aq}), 1 \% \mathrm{CaNO}_{3}{ }^{+}$ \\
$\mathrm{NO}_{3}{ }^{-}$ & $99 \% \mathrm{NO}_{3}{ }^{-}, 1 \% \mathrm{CaNO}_{3}{ }^{+}$ \\
$\mathrm{SO}_{4}{ }^{2-}$ & $67 \% \mathrm{SO}_{4}{ }^{2-}, 33 \% \mathrm{CaSO}_{4}(\mathrm{aq})$ \\
$\mathrm{PO}_{4}{ }^{3-}$ & $\mathrm{pH} 6: 78 \% \mathrm{H}_{2} \mathrm{PO}_{4}{ }^{-} ; 7,7 \% \mathrm{HPO}_{4}{ }^{2-} ; 7,5 \% \mathrm{CaHPO}_{4}{ }^{-} ; 6,7 \% \mathrm{CaH}_{2} \mathrm{PO}_{4}{ }^{+}$ \\
& $\mathrm{pH} 5: 90 \% \mathrm{H}_{2} \mathrm{PO}_{4}{ }^{-} ; 8 \% \mathrm{CaH}_{2} \mathrm{PO}_{4}{ }^{+} ; 0,9 \% \mathrm{HPO}_{4}{ }^{2-}$ \\
& $\mathrm{pH} 4: 91 \% \mathrm{H}_{2} \mathrm{PO}_{4}{ }^{-} ; 8 \% \mathrm{CaH}_{2} \mathrm{PO}_{4}{ }^{+} ; 1 \% \mathrm{HPO}_{4}{ }^{2-}$ \\
\hline
\end{tabular}


A maior parte dos ânions $\mathrm{NO}_{3}{ }^{-}$e $\mathrm{SO}_{4}{ }^{2-}$ estavam presentes na forma livre. As formas de $\mathrm{P}$ em solução dependeram do $\mathrm{pH}$ do meio. Em pHs próximos 7,2, existem quantidades equivalentes de $\mathrm{HPO}_{4}{ }^{2-}$ e $\mathrm{HPO}_{4}{ }^{-}$, porém a medida que o $\mathrm{pH}$ é reduzido o $\mathrm{H}_{2} \mathrm{PO}_{4}{ }^{2-}$ passa a espécie química mais importante em solução (Tisdale et al., 1993). Esse comportamento foi evidente para $\mathrm{O}_{2} \mathrm{PO}_{4}{ }^{2-}$, que foi a espécie de $\mathrm{P}$ predominante na solução e sofreu um ligeiro aumento na sua concentração com a diminuição do $\mathrm{pH}$. Xu \& Schwatz (1994) observaram que $\mathrm{H}_{2} \mathrm{PO}_{4}{ }^{2-}$ era a espécie solúvel de $\mathrm{P}$ predominante em soluções com pH entre 5,62-6,24. Para valores de $\mathrm{pH}$ mais elevados, superiores a 6,99, o íon $\mathrm{HPO}_{4}{ }^{-}$foi predominante.

\subsubsection{Balanço de massa nas câmaras}

A recuperação de $\mathrm{Cu}, \mathrm{Zn}$ e $\mathrm{Cd}$ antes e após o equilíbrio nas câmaras-dupla de difusão foi entre $87-117 \%$ (Tabela 18).

Tabela 18. Recuperação dos metais nas amostras (\%)

\begin{tabular}{|c|c|c|c|c|}
\hline & Tratamento & $\mathrm{Zn}$ & $\mathrm{Cu}$ & $\mathrm{Cd}$ \\
\hline Câmara 1 & $\mathrm{CaSO}_{4}$ & 88 & 95 & 107 \\
\hline \multirow[t]{4}{*}{ (LAd+biossólido) } & $\mathrm{KH}_{2} \mathrm{PO}_{4}$ & 88 & 89 & 113 \\
\hline & HA-pH 6 & 93 & 80 & 99 \\
\hline & HA-pH 5 & 88 & 86 & 112 \\
\hline & HA-pH 4 & 100 & 91 & 117 \\
\hline Câmara 2 & $\mathrm{CaSO}_{4}$ & 95 & 95 & 118 \\
\hline \multirow[t]{4}{*}{ (LVwf+biossólido) } & $\mathrm{KH}_{2} \mathrm{PO}_{4}$ & 90 & 87 & 105 \\
\hline & HA-pH 6 & 90 & 88 & \\
\hline & HA-pH 5 & 100 & 88 & 109 \\
\hline & HA-pH 4 & 87 & 95 & 112 \\
\hline
\end{tabular}


Em todas as amostras, os valores de recuperação de Cd foram superiores a 100 \%. Uma vez que a concentração de $\mathrm{Cd}$ na solução eletrolítica na qual as câmaras foram equilibradas, bem como nos ácidos usados na digestão foi igual a zero, exclui-se a possibilidade de contaminação das amostras com Cd. Foi também verificada a possível contaminação da amostra em virtude dos materiais utilizados como remediadores e não foram encontrados metais associados a esses componentes. Possivelmente, a recuperação de $\mathrm{Cd}$ superior a $100 \%$ nas amostras após o equilíbrio deve-se a interferência de algum íon presente em solução no processo de leitura, uma vez que os resultados de Cd do NIST em água atenderam os limites certificados. Uma vez atendido o critério de exigência em relação ao balanço de massa, a distribuição dos metais nas fases sólida e líquida foi calculada em termos de porcentagem do total.

\subsubsection{Distribuição dos metais nas fases sólida e líquida após o equilíbrio nas câmaras}

Em geral, a adição dos condicionadores alterou a distribuição de $\mathrm{Zn}$ e $\mathrm{Cd}$ nas fases sólidas e em solução (Figura 22). Esse efeito foi menos acentuado para o $\mathrm{Cu}$, que por sua vez, não teve sua disponibilidade afetada pelo uso de condicionadores. Esses resultados corroboram as conclusões obtidas por Smith (1994a), que não encontrou aumento na concentração de $\mathrm{Cu}$ no tecido foliar com o aumento na da acidez em solos tratados com biossólidos. $\mathrm{O} \mathrm{Cu}$ parece ser retido mais fortemente na matriz do biossólido em relação aos demais metais (Smith, 1994a), possivelmente pela sua forte interação com os óxidos de Fe e com a matéria orgânica presente nesse resíduo. Quando comparadas às amostras que receberam tratamento e a testemunha, num mesmo valor de

$\mathrm{pH}$ (5), as quantidades de $\mathrm{Zn}$ e $\mathrm{Cd}$ retidas no biossólido mudaram com a adição de $\mathrm{CaSO}_{4}, \mathrm{KH}_{2} \mathrm{PO}_{4}$ ou HA. As quantidades dos metais em solução foram também alteradas com a utilização dos condicionadores. Por exemplo, cerca de $48 \%$ do $\mathrm{Zn}$ total estava presente em solução na câmara equilibrada sem o uso de condicionadores com o LAd, porém com a introdução de $\mathrm{CaSO}_{4}, \mathrm{KH}_{2} \mathrm{PO}_{4}$ e $\mathrm{HA}$, esse valor foi ao redor de 20, 32 e 28 $\%$ do $\mathrm{Zn}$ total, respectivamente. Resultados semelhantes foram obtidos para Cd, e em 


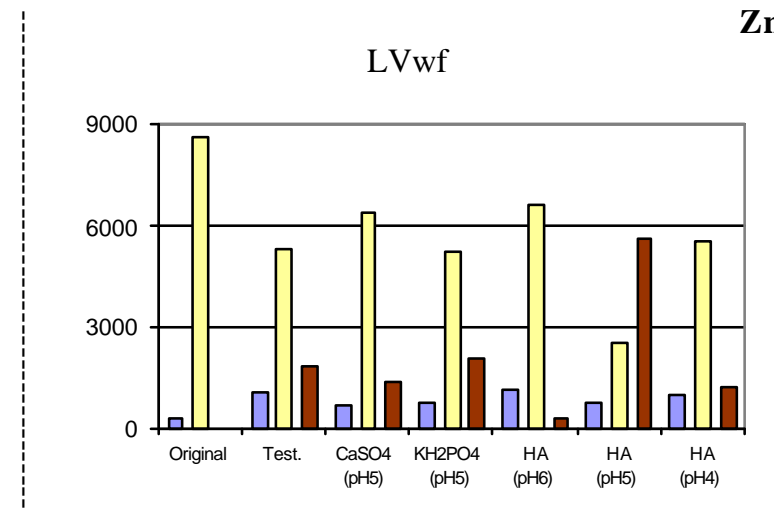

Zn

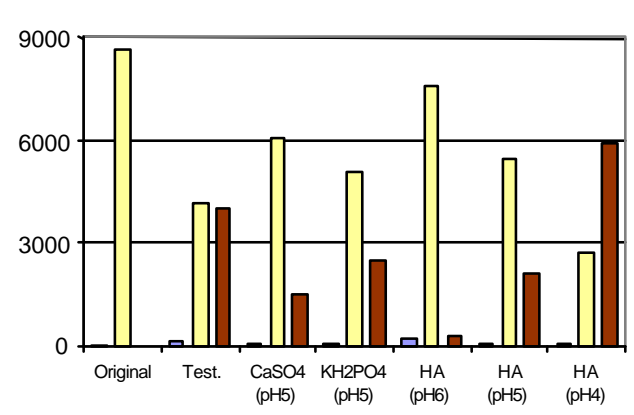

LVwf

$\mathbf{C u}$

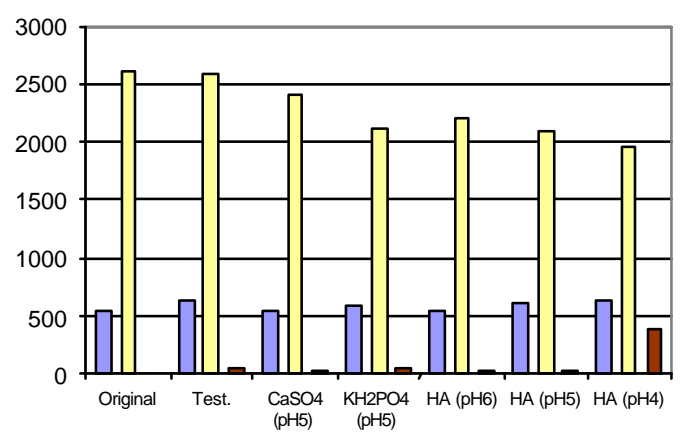

Cd

LVwf

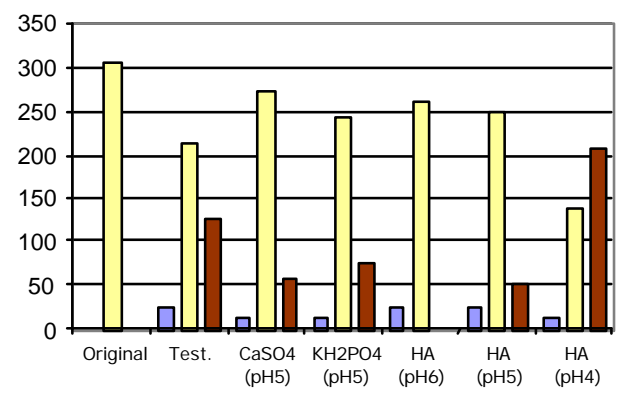

LAd

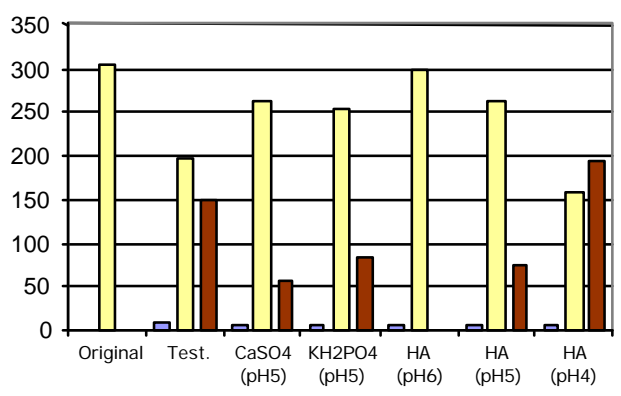

Figura 22 - Distribuição de Zn, Cu e Cd nas fases sólida (2 g de terra e de biossólido) e em solução $(500 \mathrm{~mL})$. Original $=$ amostras antes do equilíbrio nas câmaras; Testemunha = após o equilíbrio nas câmaras, porém sem adição de condicionadores.

\begin{tabular}{|l|l|l|l|l|l}
$\square$ Solo $\square$ Biossólido $\square$ Solução \\
\hline
\end{tabular}


geral, houve uma redução de $51 \%$ na quantidade do metal em solução com a adição de condicionadores no mesmo valor de $\mathrm{pH}$ da amostra testemunha ( $\mathrm{pH}$ 5). Ma et al. (1994), estudando o efeito dos metais na imobilização de $\mathrm{Pb}$, observaram que a $\mathrm{HA}$ apresentava capacidade de reter esses metais na ordem: $\mathrm{Al}>\mathrm{Zn}>\mathrm{Fe}(\mathrm{II})>\mathrm{Cd}>\mathrm{Cu}>\mathrm{Ni}$. Concordando com essa seqüência de afinidade proposta por Ma et al. (1994), as quantidades de Zn e o $\mathrm{Cd}$ em solução foram afetadas mais acentuadamente do que o $\mathrm{Cu}$ quando se adicionou HA. Sugere-se que a redução nas quantidades dos metais em solução foi devida à incorporação ou coprecipitação desses elementos nos sítios de adsorção de Ca da HA ou nos radicais hidroxílicos da superfície da HA. Possivelmente, o Ca foi deslocado do complexo de troca da HA e foi substituído pelo $\mathrm{Zn}$ ou pelo $\mathrm{Cd}$. Esse fenômeno de coprecipitação pode ser descrito para o Zn como (eq. 9) (Xu\& Schwartz, 1994):

$$
\begin{aligned}
& -\mathrm{CaOH}+\mathrm{Zn}^{2+}=-\mathrm{CaOZn}^{+}+\mathrm{H}^{+} \\
& -\mathrm{POH}+\mathrm{Zn}^{2+}=-\mathrm{POZn}^{+}+\mathrm{H}^{+} \ldots .
\end{aligned}
$$

Xu \& Schwartz (1994) ressaltam que o mecanismo de coprecipitação descrito na equação 9 é mais importante na faixa de $\mathrm{pH}$ entre 6,85 a 7,22, porém, em pHs inferiores (entre 5,64 a 6,85) a reação do $\mathrm{Zn}$ com a superfície -POH é mais importante (eq. 10). Esses autores explicaram que esse comportamento se deve ao ponto de carga zero da HA. Em pHs inferiores ao PCZ da HA, a forma $-\mathrm{POH}$ se torna predominante em relação às demais espécies químicas, porém, nos $\mathrm{pHs}>\mathrm{PCZ}$ a forma $-\mathrm{CaOH}$ é mais importante.

A elevação do $\mathrm{pH}$ com $\mathrm{CaCO}_{3}$ e no tratamento $\mathrm{HA}(\mathrm{pH}$ 6) resultou em menor disponibilização dos metais do biossólido e, consequientemente, em solução. Para ambos os solos, a porcentagem de $\mathrm{Zn}, \mathrm{Cu}$ e $\mathrm{Cd}$ em solução variou entre 0 a 3 do total nas amostras tratadas com $\mathrm{CaCO}_{3}$ e entre 0 a 4 no tratamento com HA (pH 6). Fang \& Wong (1999) observaram que o tratamento de biossólidos com $\mathrm{CaCO}_{3}$ reduziu as quantidades de metais solúveis e trocáveis. Porém, esses autores sugerem que sejam utilizadas doses de $\mathrm{CaCO}_{3}$ inferiores a $1 \%$ (base massa), pois doses mais elevadas podem promover perdas de nitrogênio do biossólido via volatilização. A redução nos 
teores dos metais em solução em resposta ao uso de $\mathrm{CaCO}_{3}$ deve-se ao aumento no número de sítios na fase sólida capazes de retê-los ou a elevação na energia da ligação (Hamon et al., 2002). A redução nos níveis de $\mathrm{Cu}$ e $\mathrm{Zn}$ trocáveis devido ao tratamento com $\mathrm{CaCO}_{3}$ obtidos por Fang \& Wong (1999) foram iguais a 45 e $70 \%$, respectivamente, quando comparados à amostra sem tratamento e, para $\mathrm{o} \mathrm{Cd}$, não foi detectada a presença desse metal na fração trocável após o tratamento. Hamon et al. (2002) observaram que o $\mathrm{KH}_{2} \mathrm{PO}_{4}$ foi mais eficiente na diminuição da concentração de $\mathrm{Cd}$ e $\mathrm{Zn}$ em solução do que o $\mathrm{CaCO}_{3}$. Esses resultados diferem dos obtidos no presente trabalho. Possivelmente, a maior quantidade de $\mathrm{KH}_{2} \mathrm{PO}_{4}$ utilizada no trabalho de Hamon et al. (2002) (20 $\mathrm{g} \mathrm{P} \mathrm{kg}^{-1}$ solo) e a correção do $\mathrm{pH}$ com $\mathrm{CaO}$ para 7,2, resultaram em maior imobilização de metais. Porém, esses autores ressaltam que as quantidades de metais em solos tratados com $\mathrm{KH}_{2} \mathrm{PO}_{4}$ aumentam exponencialmente com a redução do $\mathrm{pH}$.

Assim como observado por Hamon et al. (2002), o pH da solução afetou os tratamentos. Ao contrário do observado por Ma et al. (1993), a redução do pH não resultou em maior imobilização dos metais em solução. A diminuição do pH para 4 no tratamento com HA resultou em dissolução mais acentuada sobretudo de $\mathrm{Zn}$ e $\mathrm{Cd}$ e, em menor proporção, $\mathrm{Cu}$ do biossólido. Como consequiência houve maior concentração desses metais em solução nesse tratamento em relação aos demais. Esses resultados descartam a hipótese de que, em menores valores de $\mathrm{pH}$, a dissolução da HA é favorecida, resultando em maior concentração de $\mathrm{PO}_{4}$ e, conseqüentemente, maior complexação dos metais em solução. No presente trabalho o efeito do $\mathrm{pH}$ pareceu ser mais importante, uma vez que a HA estava totalmente dissolvida, mesmo em valores de $\mathrm{pH}$ mais elevados (Tabela 17). Esse efeito poderia ter sido evidenciado se fossem utilizadas doses mais elevadas de HA e/ou de metais em solução. Por exemplo, Ma et al. (1993) observaram que $0,2 \mathrm{~g}$ de HA reagindo com uma solução contendo $500 \mathrm{mg} \mathrm{Pb} \mathrm{L}^{-1}$ foi suficiente para haver a formação de hidroxipiromorfita, e a redução do $\mathrm{pH}$ da solução favoreceu a formação desse mineral. Porém, Boisson et al. (1999) encontraram que o aumento no $\mathrm{pH}$ da solução favorecia os mecanismos de troca iônica e complexação de superfície entre os metais e a HA, e que a dose de $1 \%$ a HA $(\mathrm{pH} 5,6)$ foi capaz de 
reduzir significativamente os teores trocáveis de $\mathrm{Cd}, \mathrm{Pb}, \mathrm{Cu}$ e $\mathrm{Zn}$ no solo. $\mathrm{Xu}$ \& Schwartz (1994) observaram maior adsorção de Cd e Zn devido ao tratamento com HA em pHs mais elevados na solução. Portanto, o efeito do $\mathrm{pH}$ parece depender das quantidades de HA e de metais em solução. $\mathrm{O}$ aumento na acidez pode favorecer a dissolução da HA e, contrariamente, a elevação do pH favorece os mecanismos de troca nesse material. Uma vez que a dose de HA foi totalmente dissolvida, mesmo nos $\mathrm{pHs}$ mais elevados (Tabela 17), sugere-se que o segundo mecanismo foi mais importante nesse experimento.

\subsubsection{Efeito dos condicionadores na retenção dos metais no biossólido}

De forma geral, as quantidades de metais solubilizadas do biossólido foram superiores na amostra equilibrada com o LVwf quando comparada ao LAd, sobretudo para $\mathrm{Cu}$ e $\mathrm{Cd}$ (Figura 23). Isso pode ter ocorrido devido maior capacidade em adsorver metais do LVwf e/ou maior quantidade de ligantes orgânicos e inorgânicos capazes de deslocar o equilíbrio em solução (eq. 6). A menor concentração de metais em solução no LVwf (Figuras 22) confirma a hipótese de que os atributos do solo podem influenciar a reação de dissolução do biossólido.Em termos gerais, o $\mathrm{CaCO}_{3}$ foi o condicionador mais eficiente na redução da disponibilização de metais do biossólido, sobretudo $\mathrm{Zn}$ e $\mathrm{Cd}$, para solução (Figura 23). A capacidade de adsorção do solo não foi afetada significativamente com a variação do $\mathrm{pH}$ da solução e/ou com a incorporação dos condicionadores. Para os três metais estudados o LVwf apresentou maior capacidade em adsorvê-los em comparação ao LAd. Isso se deve, possivelmente, aos maiores conteúdos de óxidos de Fe e argila presentes no LVwf.

Para o $\mathrm{Zn}$, cerca de 65-79 \% do total permaneceu no biossólido nos tratamentos

equilibrados no pH $5\left(\mathrm{CaSO}_{4}, \mathrm{KH}_{2} \mathrm{PO}_{4}\right.$ e $\left.\mathrm{HA}\right)$ em ambos os solos (Figura 23A). A adição dos condicionadores reduziu a disponibilização de metais no biossólido equilibrado com o LAd. Nesse solo, a pH 5, ficaram retidos $50 \% \mathrm{Zn}$ total na amostra testemunha e, em contrapartida, quando se utilizaram $\mathrm{CaSO}_{4}, \mathrm{KH}_{2} \mathrm{PO}_{4}$ e $\mathrm{HA}$, nesse mesmo $\mathrm{pH}$, os valores foram aumentados para cerca de 66-79 \% do total. Em geral, as 
A

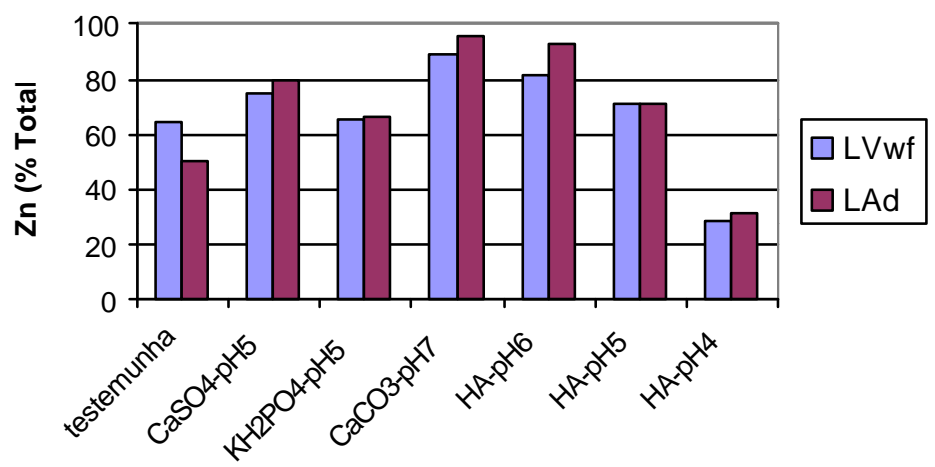

B

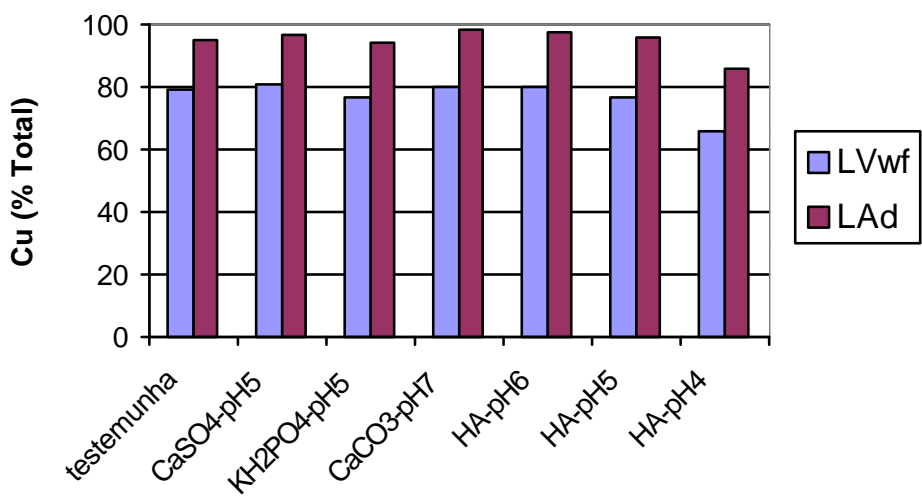

C

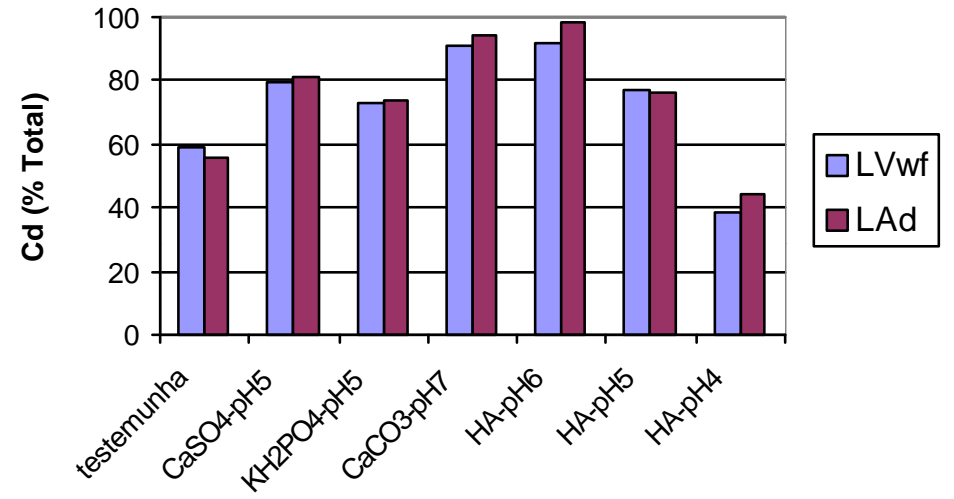

Figura 23 - Porcentagem dos metais retidos nas amostras de biossólido após o equilíbrio com as amostras de terra. 
quantidades de $\mathrm{Zn}$ solubilizadas no biossólido equilibrado com o LVwf foram superiores quando comparadas à amostra que reagiu com o LAd. Por exemplo, nos tratamentos com HA (pHs 6 e 4), as quantidades do metal retidas no biossólido foram ao redor de 82 e $28 \%$ no LVwf e 93 e $31 \%$ no LAd, respectivamente. Possivelmente, devido a maior capacidade de adsorção do LVwf, o equilíbrio da reação foi deslocado, favorecendo a maior dissolução do biossólido. No tratamento com $\mathrm{CaCO}_{3}$ a maior parte do $\mathrm{Zn}$ ficou no biossólido (96 \% do total no LAd e $89 \%$ no LVwf).

Para o $\mathrm{Cu}$, o efeito dos condicionadores e/ou do $\mathrm{pH}$ da solução não alterou a dissolução do biossólido (Figura 23B). Na amostra equilibrada com o LVwf, cerca de 79 $\%$ do metal ficou retido na amostra testemunha e $77-81 \%$ nas amostras tratadas com os condicionadores, com exceção do tratamento HA ( $\mathrm{pH} 4)$, no qual ficaram retidos $66 \%$ do $\mathrm{Cu}$ total no biossólido. Na amostra que reagiu com o LAd, ao redor de 95-97\% ficaram retidos no biossólido sem e com tratamento e, aproximadamente $86 \%$ do $\mathrm{Cu}$ total no HA ( $\mathrm{pH} 4)$. O cobre foi menos afetado em resposta ao uso dos condicionadores e/ou da variação do pH da solução, em relação aos demais metais. Isso se deve, possivelmente, à elevada afinidade da superfície dos colóides em reter esse metal e ao efeito menos acentuado das mudanças no $\mathrm{pH}$ na disponibilização de $\mathrm{Cu}$ em solos tratados com biossólidos (Smith, 1994a). Porém, novamente a quantidade de $\mathrm{Cu}$ disponibilizada pelo biossólido equilibrado com o LVwf foi superior em todos tratamentos quando comparado ao LAd. Embora ambos os Latossolos apresentem baixos teores de $\mathrm{C}$ orgânico, possivelmente a maior concentração no LVwf pode ter resultado em maior quantidade de ligantes orgânicos em solução, o que favoreceu a dissolução do $\mathrm{Cu}$ do biossólido. Salam \& Helmke (1998) observaram que a quantidade de $\mathrm{Cu}$ em solução era mais afetada em relação aos demais metais dependendo da quantidade de ligantes orgânicos em solução.

Com relação ao $\mathrm{Cd}$, todos os tratamentos, com exceção do $\mathrm{HA}$ (pH 4), resultou em menor disponibilização do metal do biossólido (Figura 23C). Cerca de 56-59 \% do Cd estava presente nas amostras de biossólido sem adição dos condicionadores. Porém, com a adição de $\mathrm{CaSO}_{4}, \mathrm{KH}_{2} \mathrm{PO}_{4}$ e $\mathrm{HA}(\mathrm{pH} 5)$ esse valor variou entre 73-79 \% no LVwf 
e 74-81 \% no LAd. $\mathrm{O}$ aumento no $\mathrm{pH}$ (tratamentos $\mathrm{HA}-\mathrm{pH} 6$ e $\mathrm{CaCO}_{3}$ ) elevou a quantidade de Cd retida no biossólido para até $98 \%$ do total.

\subsubsection{Distribuição de Zn na fase sólida}

Nas amostras testemunha, o $\mathrm{Zn}$ foi encontrado principalmente na fração residual e Fe crist. no LVwf (44\% do total) e na forma trocável no LAd (78 \% do Zn total) (Figura 24). A maior capacidade do LVwf em reter o $\mathrm{Zn}$ em formas pouco móveis se deve, sobretudo à presença de caulinita na fração mineralógica desse solo (Figura 3), além do maior teor de óxidos de Fe cristalino (Tabela 5). A capacidade de adsorção de Zn foi superior no LVwf (Figura 24). A aplicação dos condicionadores não resultou em incremento significativo na adsorção de Zn pelos solos. Apenas no LAd houve um ligeiro aumento na adsorção desse metal nos tratamentos com $\mathrm{pHs}$ mais elevados $\left(\mathrm{CaCO}_{3}\right.$ e HA-pH 6), provavelmente devido a maior afinidade da superfície adsorvente em adsorver o $\mathrm{Zn}$ nessas condições.

A adição dos condicionadores resultou numa diminuição nas quantidades de $\mathrm{Zn}$ retidas na fração trocável em ambos os solos e elevação nos teores do metal obtidos na fração Superf. Ox. (Figura 24). Esse efeito foi mais pronunciado quando se utilizou $\mathrm{CaCO}_{3}$. Após a adição desse condicionador, o LVwf teve uma redução de $22 \%$ para 0 $\%$ do $\mathrm{Zn}$ associado à fração Troc. e de $78 \%$ para $3 \%$ no LAd. Paralelamente, houve um aumento de 10-27 \% e de 13-68 \% do Zn total retido na fração Superf.Ox. no LVwf e no LAd, respectivamente. A elevação do $\mathrm{pH}$ devido ao uso de $\mathrm{CaCO}_{3}$ resulta na transferência dos metais para formas moderadamente lábeis que apenas são presentes em pHs elevados, tais como a fração carbonato (Hamon et al., 2002). Portanto, devido às formas de $\mathrm{Zn}$ predominantes no tratamento com $\mathrm{CaCO}_{3}$, a possível reacidificação posterior pode resultar na disponibilização do $\mathrm{Zn}$ para solução.

Em seguida ao $\mathrm{CaCO}_{3}$, o tratamento HA-pH 6 foi o que ocasionou maior redução na porcentagem de $\mathrm{Zn}$ retido na forma trocável. Após a adição da HA-pH 6 ao redor de $12 \%$ e $40 \%$ do Zn total estavam retidos na fração Troc. no LVwf e no LAd, 


\section{LVwf}
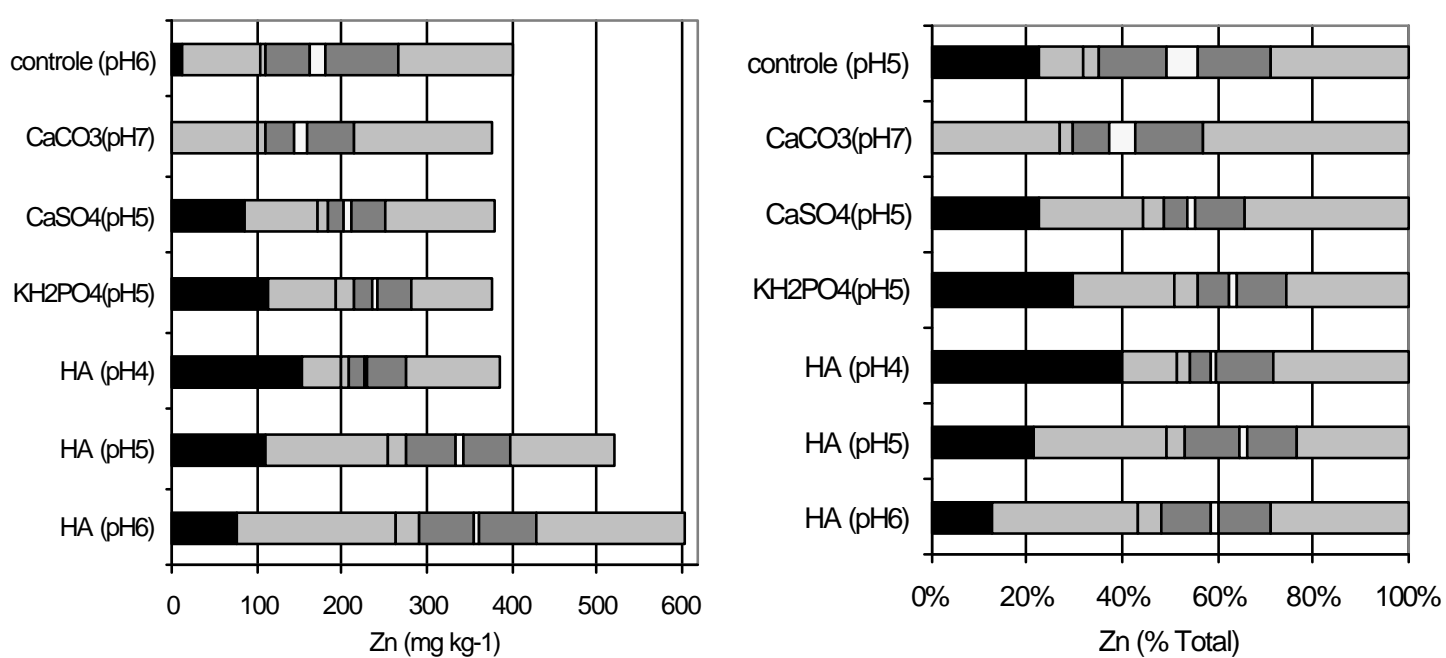

LAd
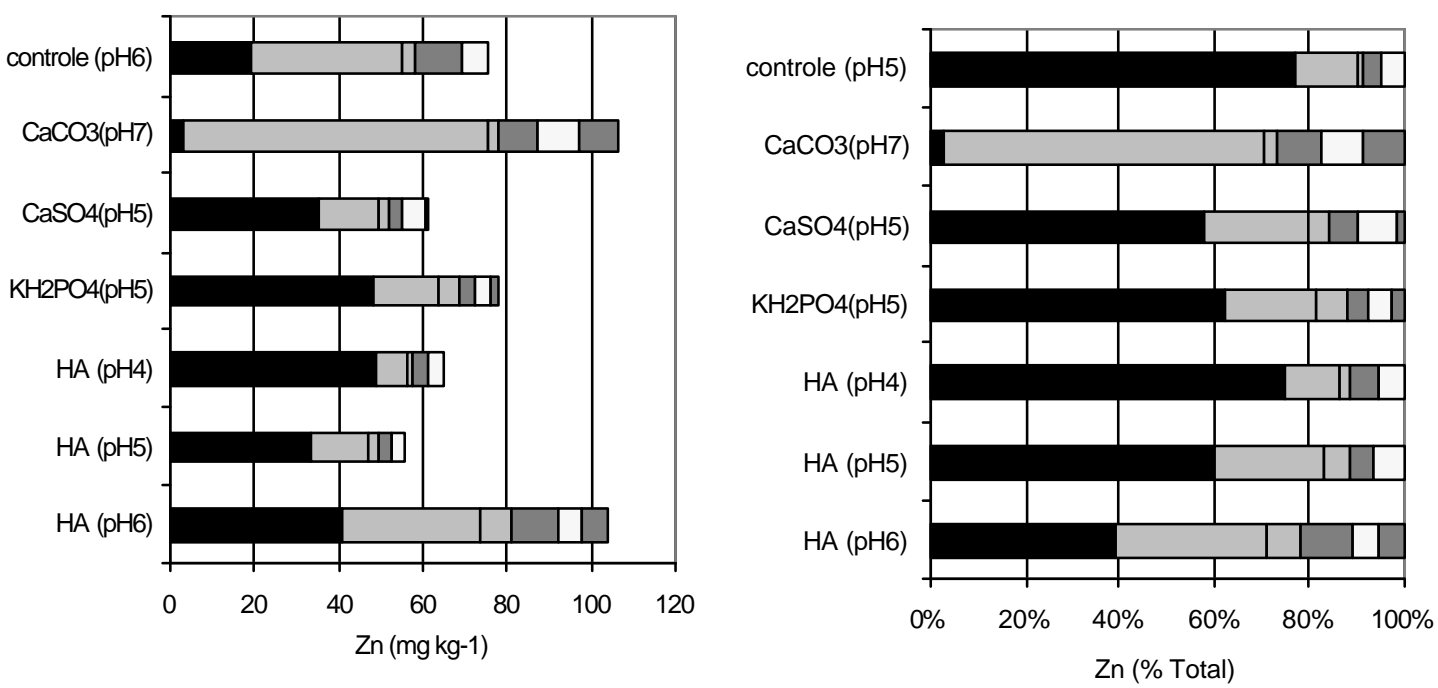

Figura 24 - Distribuição de Zn nas amostras de terra.

=Troc. $\square=$ =Superf.Ox. $\square=$ MO $\square=$ Ox.Mn $\square$ = Fe Ox. $\square$ = Fe crist. $\square=$ Res 
respectivamente. As demais frações não sofreram alterações com a adição dos condicionadores. Boisson et al. (1999) observaram que o uso da HA foi capaz de reduzir os teores trocáveis dos metais em solos contaminados para níveis inferiores aos encontrados em amostras controle (não contaminadas). Esse efeito foi mais acentuado para $\mathrm{Zn}$ e $\mathrm{Cd}$ em relação ao $\mathrm{Cu}$. Isso se deve por ao raio iônico do $\mathrm{Cd}(0,097 \mathrm{~nm})$ ser mais próximo ao raio iônico do $\mathrm{Ca}(0,094 \mathrm{~nm})$, o que favorece a substituição isomórfica entre esses cátions em relação ao $\mathrm{Zn}$, cujo raio iônico é ao redor de $0,074 \mathrm{~nm}$ e ao $\mathrm{Cu}$ (0,069 nm) (Boisson, et al., 1999). Corroborando com esses resultados, Xu \& Schwartz (1994) observaram que, em condições experimentais específicas, maiores quantidades de $\mathrm{Cd}$ eram retidas na $\mathrm{HA}$ em relação ao $\mathrm{Zn}$. Porém, embora o $\mathrm{Cd}$ fosse retido em maior proporção, a quantidade de $\mathrm{Zn}$ desorvida era menor, sugerindo que esse último metal era retido mais fortemente na $\mathrm{HA}$.

Num mesmo pH, a adição de $\mathrm{CaSO}_{4}, \mathrm{KH}_{2} \mathrm{PO}_{4}$ e $\mathrm{HA}$ resultou em menor quantidade de Zn-Troc. apenas no LAd, onde a redução foi ao redor de $20 \%$ na fração trocável, seguida de um aumento médio de 70 \% na fração Superf. Ox. (Figura 24). Já para o LVwf não foi observada diferença na distribuição de $\mathrm{Zn}$ com a adição de $\mathrm{CaSO}_{4}$, $\mathrm{KH}_{2} \mathrm{PO}_{4}$ e HA no $\mathrm{pH} 5$, possivelmente pela participação da fração residual e ligado aos óxidos de $\mathrm{Fe}$ na retenção desse metal. $\mathrm{O}$ tratamento com $\mathrm{KH}_{2} \mathrm{PO}_{4}$ no $\mathrm{LVwf}$ resultou num ligeiro aumento na quantidade de Zn-Troc. de $22 \%$ para $30 \%$ (amostra testemunha e tratada, respectivamente). Resultados semelhantes foram observados por Shuman (1988), que concluiu que a adição de $\mathrm{KH}_{2} \mathrm{PO}_{4}$, nas doses de $30-60 \mathrm{mg} \mathrm{kg}$, era capaz de aumentar a quantidade do metal trocável em solos com $\mathrm{pH}$ próximos ao encontrado no LVWf. Quando comparada à distribuição de $\mathrm{Zn}$ nas amostras de terra submetidas ao tratamento com $\mathrm{CaSO}_{4}, \mathrm{KH}_{2} \mathrm{PO}_{4}$ ou $\mathrm{HA}$, notou-se que não houve diferença dentre esses condicionadores. Em todos os casos, a fração Superf. Ox. foi aumentada em relação à amostra original. $\mathrm{O}$ tratamento $\mathrm{HA}-\mathrm{pH} 4$ resultou numa distribuição de $\mathrm{Zn}$ semelhante à amostra testemunha em ambos os solos

A distribuição de $\mathrm{Zn}$ nas frações foi bastante semelhante nas amostras de biossólido equlibradas com o LVwf ou com o LAd (Figura 25). A maior parte do metal ficou retido nas frações Superf. Ox. e Ox. Mn. O efeito dos condicionadores foi mais 


\section{Biossólido 1*}
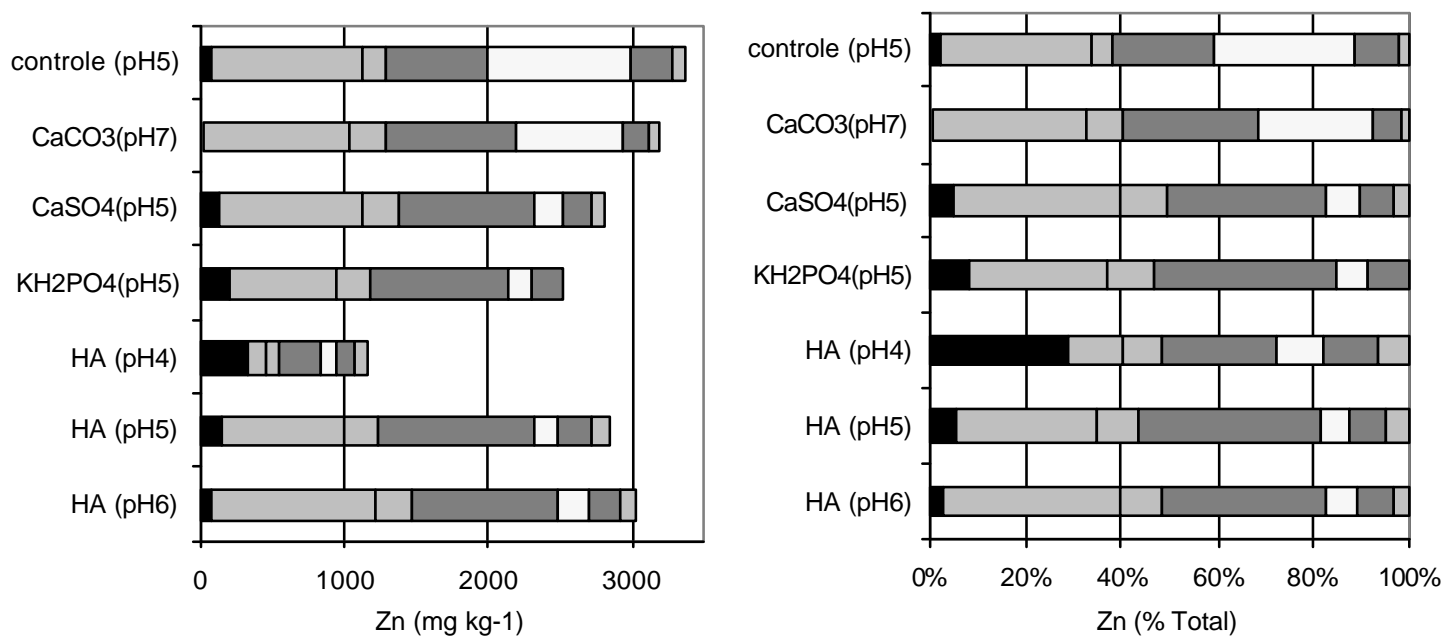

Biossólido 2**
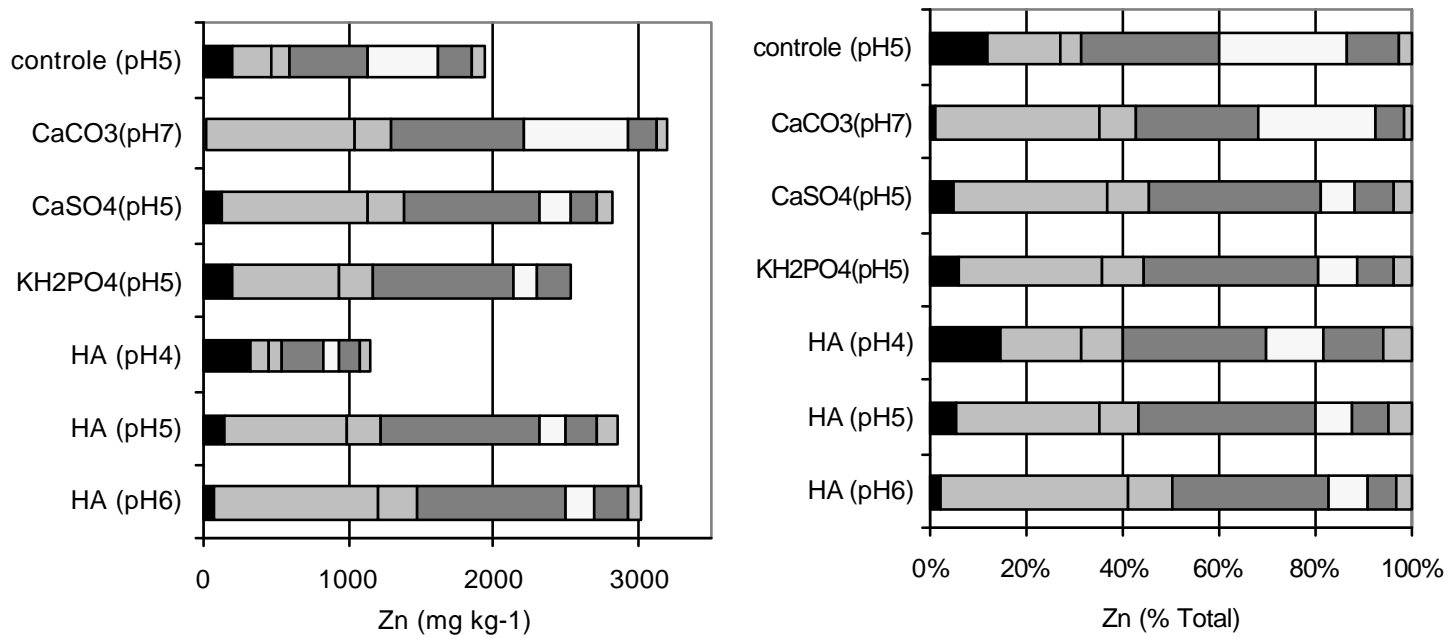

Figura 25 - Distribuição de Zn nas amostras de biossólido. *Biossólido 1 = equilibrado com o LVwf; **Biossólido 2 = equilibrado com o LAd.

=Troc. $\square=$ =Superf.Ox. $\square=$ MO $\square=$ Ox.Mn $\square=$ Fe Ox. $\square$ = Fe crist. $\square=$ Res 
evidente no tratamento com $\mathrm{CaCO}_{3}$, que resultou na diminuição da fração $\mathrm{Zn}$-Troc. (11 $\%$ para $1 \%$ do Zn total) (Figura 25). Resultados semelhantes foram obtidos por Fang \& Wong (1999) e Wong \& Fang (2000). Os autores encontraram significativa redução nos teores de Zn-trocável em amostras de biossólido tratadas com $\mathrm{CaCO}_{3}$. Os demais tratamentos não alteraram significativamente a distribuição de Zn no biossólido.

\subsubsection{Distribuição de Cu na fase sólida}

Em ambos os solos, o $\mathrm{Cu}$ foi encontrado principalmente nas frações residual, ligados aos óxidos de $\mathrm{Mn}$ e/ou adsorvido na superfície dos óxidos (Figura 26). Na amostra testemunha do LVwf, cerca de $53 \%$ do $\mathrm{Cu}$ total estava retido na fração Res e 16 \% na Ox. Mn. Já no LAd, 50 \% do Cu total foi encontrado na fração Superf. Ox. e 23 $\%$ na Ox. Mn. Morera et al. (2001) encontraram distribuição de $\mathrm{Cu}$ semelhante à encontrada no LAd, ou seja, cerca de $56 \%$ do Cu estava retido na fração extraída com o mesmo reagente da denominada como Superf. Ox. A maior importância da fração residual na retenção de $\mathrm{Cu}$ no LVwf, deve-se ao maior teor de argila (Tabela 4 ) e a presença de caulinita na fração mineralógica desse solo (Figura 3). A adição dos condicionadores não alterou a distribuição de $\mathrm{Cu}$ nos solos. Isso ocorreu, provavelmente, porque o $\mathrm{Cu}$ encontrava-se em formas pouco móveis nas amostras testemunha. Nessa situação, o efeito dos condicionadores foi menos acentuado. A disponiblidade de $\mathrm{Cu}$ parece pouco afetada em resposta às variações do meio (Smith, 1994a), tal como a adição de condicionadores, devido a elevada afinidade dos colóides em adsorvê-lo (Morera et al. 2991). No LAd, a adição dos condicionadores resultou no aumento da quantidade do metal retido na fração Res (0 \% na amostra testemunha para ao redor de 10-17\% do $\mathrm{Cu}$ total nas amostras tratadas), enquanto no LVwf esse aumento foi de 53 \% para 63-70 \% do $\mathrm{Cu}$ total. Shuman (1988) encontrou que em solos tratados com $\mathrm{KH}_{2} \mathrm{PO}_{4}$ a quantidade de $\mathrm{Cu}$ retida na fração trocável foi ligeiramente diminuída, seguida de um aumento na fração residual.

Nos biossólidos, o $\mathrm{Cu}$ estava retido nas frações Fe Ox., Ox. Mn, Superf. Ox. e MO (Figura 27). 


\section{LVwf}
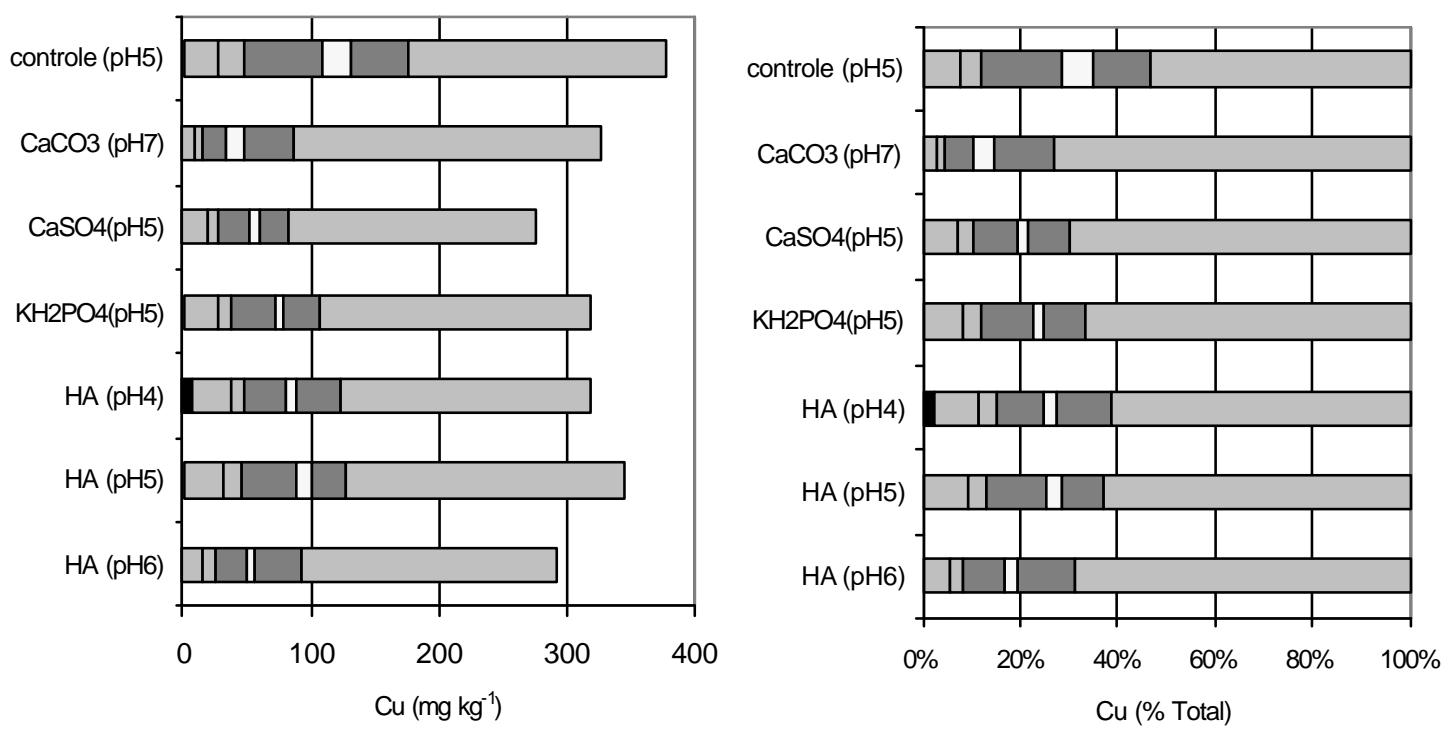

\section{LAd}
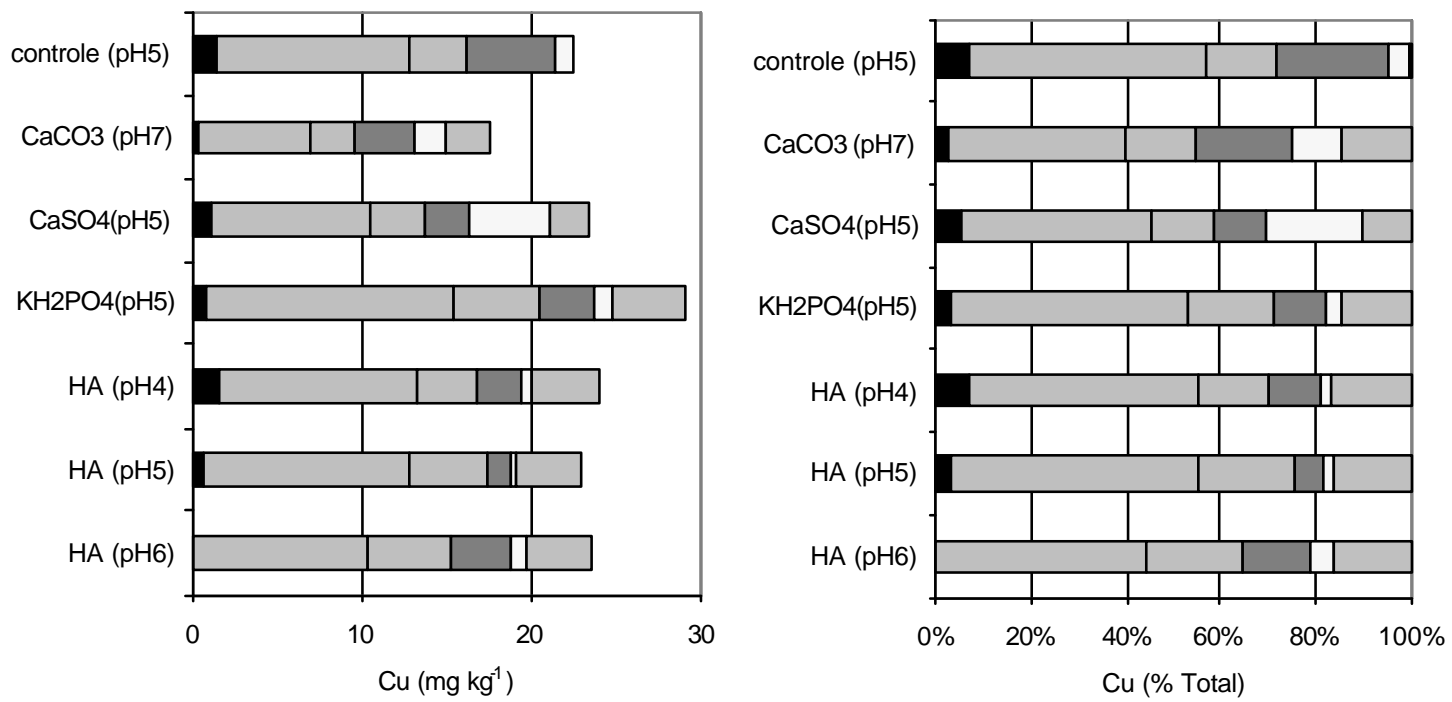

Figura 26 - Distribuição de Cu nas amostras de terra.

=Troc. $\square=$ =Superf.Ox. $\square=$ MO $\square=$ Ox.Mn $\square=$ Fe Ox. $\square=$ Fe crist. $\square=$ Res 


\section{Biossólido 1*}
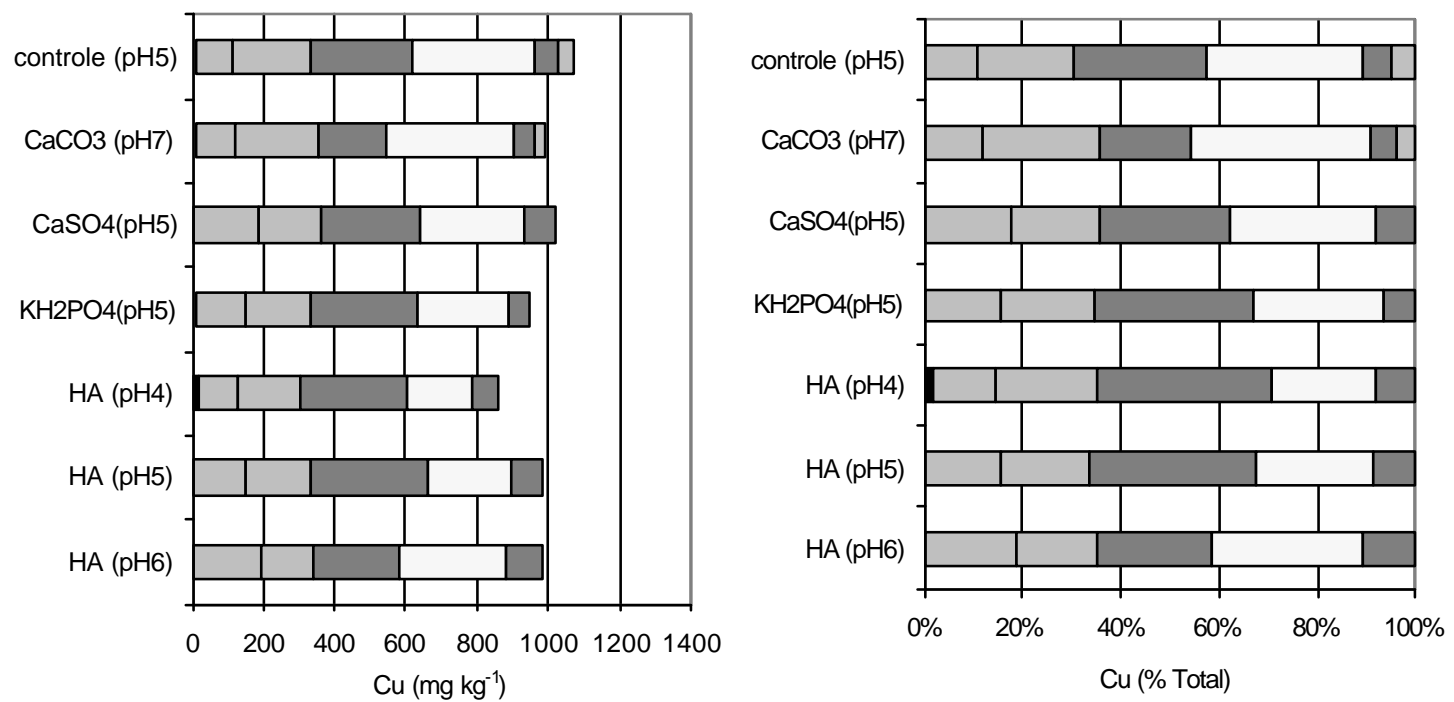

Biossólido 2**
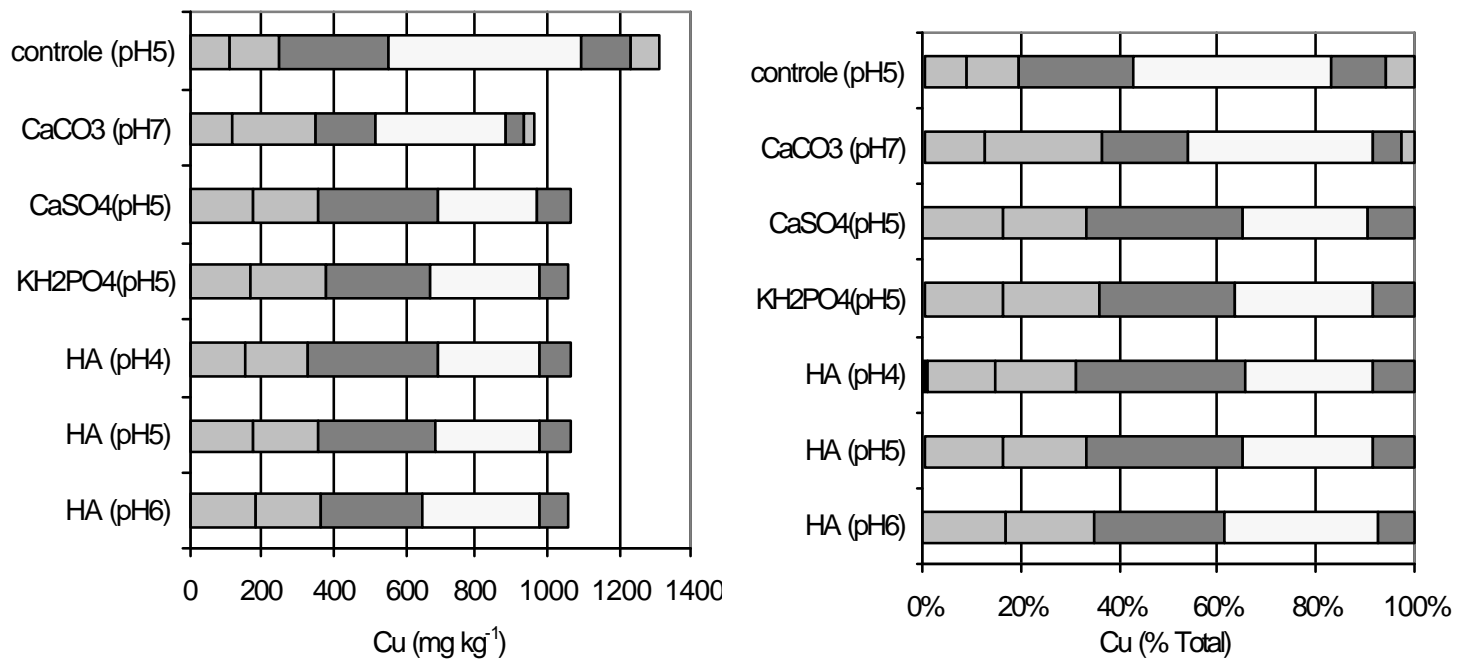

Figura 27 - Distribuição de Cu nas amostras de biossólido. *Biossólido 1 = equilibrado com o LVwf; **Biossólido 2 = equilibrado com o LAd.

=Troc. $\square$ =Superf.Ox. $\square=$ MO $\square=$ Ox.Mn $\square=$ Fe Ox. $\square$ = Fe crist. $\square=$ Res 
Não houve alteração na distribuição de $\mathrm{Cu}$ com a adição dos condicionadores. Assim como ocorreu nos solos, a fração residual foi ligeiramente aumentada de 0 para $46 \%$ do $\mathrm{Cu}$ total. $\mathrm{O} \mathrm{Cu}$ foi encontrado associado principalmente às fações $\mathrm{Fe} \mathrm{Ox}$ e $\mathrm{Ox}$. Mn e, em menor importância, a Superf.Ox. e MO.

\subsubsection{Distribuição de Cd na fase sólida}

Em ambos os solos o Cd foi encontrado, sobretudo, nas frações Superf. Ox. e Troc. (Figura 28). No LVwf, essas frações corresponderam à cerca de $64 \%$ do Cd total e no LAd ao redor de $96 \%$. O uso dos condicionadores reduziu as quantidades desse metal na forma trocável e aumentou, principalmente, a fração Superf. Ox. Isso significou uma redução na disponiblidade do metal às plantas, uma vez que, embora a fração Superf. Ox. possa ser solublizada, a fração trocável consiste numa forma mais prontamente disponível. Quando comparado à amostra testemunha, o tratamento com $\mathrm{CaCO}_{3}$, por exemplo, resultou na redução do Cd-Troc. de $45 \%$ do total para zero no LVwf e de $82 \%$ do total para $11 \%$. Embora apresente eficiência menos marcante que o $\mathrm{CaCO}_{3}$, a $\mathrm{HA}$, o $\mathrm{CaSO}_{4}$ e o $\mathrm{KH}_{2} \mathrm{PO}_{4}$ também promoveram a redução nas quantidades trocáveis de $\mathrm{Cd}$. A HA ( $\mathrm{pH}$ 6), por exemplo, reduziu as porcentagens de Cd-Troc. em 42 e $28 \%$ no LVwf e no LAd, respectivamente, em relação à amostra testemunha. Isso significa que, dependendo do nível de contaminação dos solos e dos metais presentes, a escolha do condicionador pode ser realizada em função do custo ou das práticas de manejo adotadas na áreas, tal como a necessidade de calagem e/ou correção com $\mathrm{CaSO}_{4}$. Assim como o observado por Xu \& Schwartz (1994), nos valores mais elevados de pH houve maior sorção de $\mathrm{Cd}$. No pH 5 não houve diferenças marcantes na distribuição de $\mathrm{Cd}$ nas amostras tratadas com $\mathrm{HA}, \mathrm{CaSO}_{4}$ ou $\mathrm{KH}_{2} \mathrm{PO}_{4}$. Porém, a redução do $\mathrm{pH}$ para 4 no tratamento com HA resultou em maior quantidade de Cd-Troc. em relação à amostra testemunha, possivelmente pelo efeito do $\mathrm{pH}$. No $\mathrm{pH} 4$ houve maior dissolução do biossólido em relação ao $\mathrm{pH}$ da amostra testemunha e, conseqüentemente, maior 


\section{LVwf}
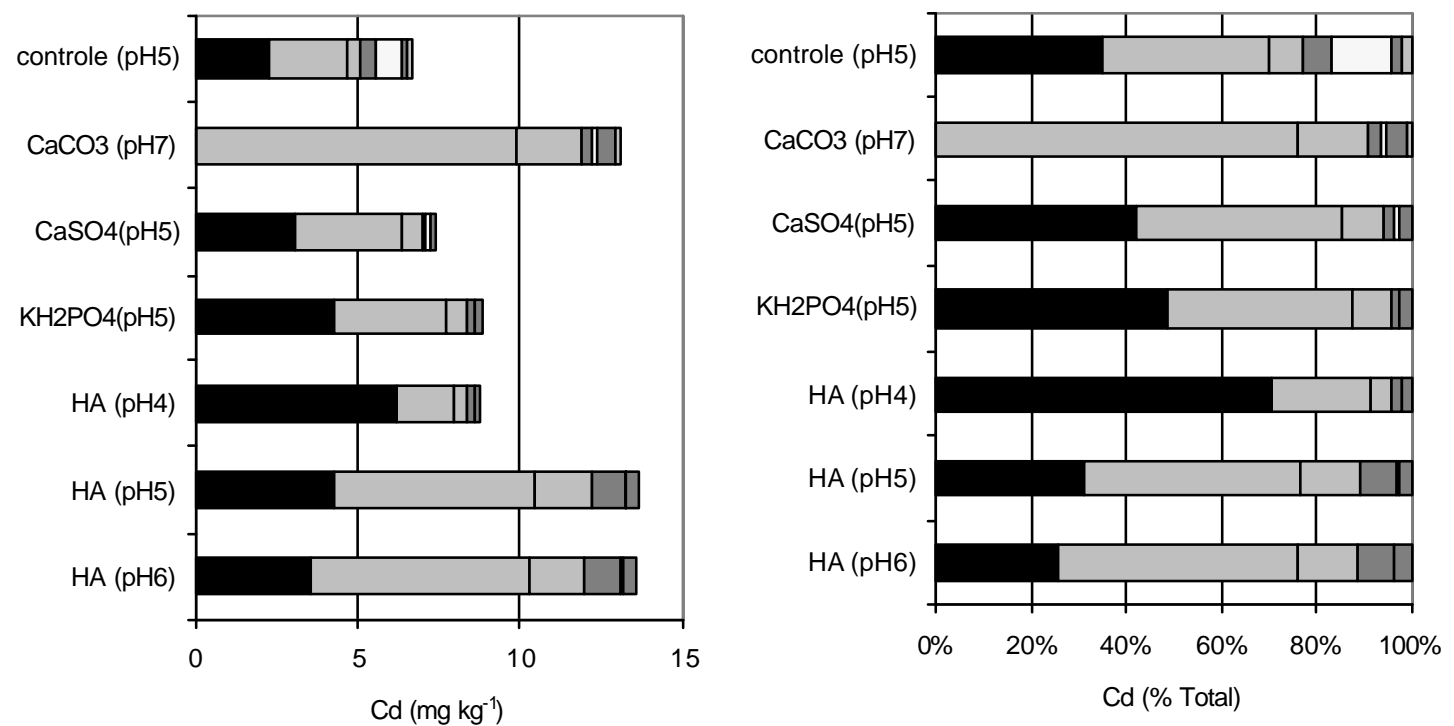

\section{LAd}
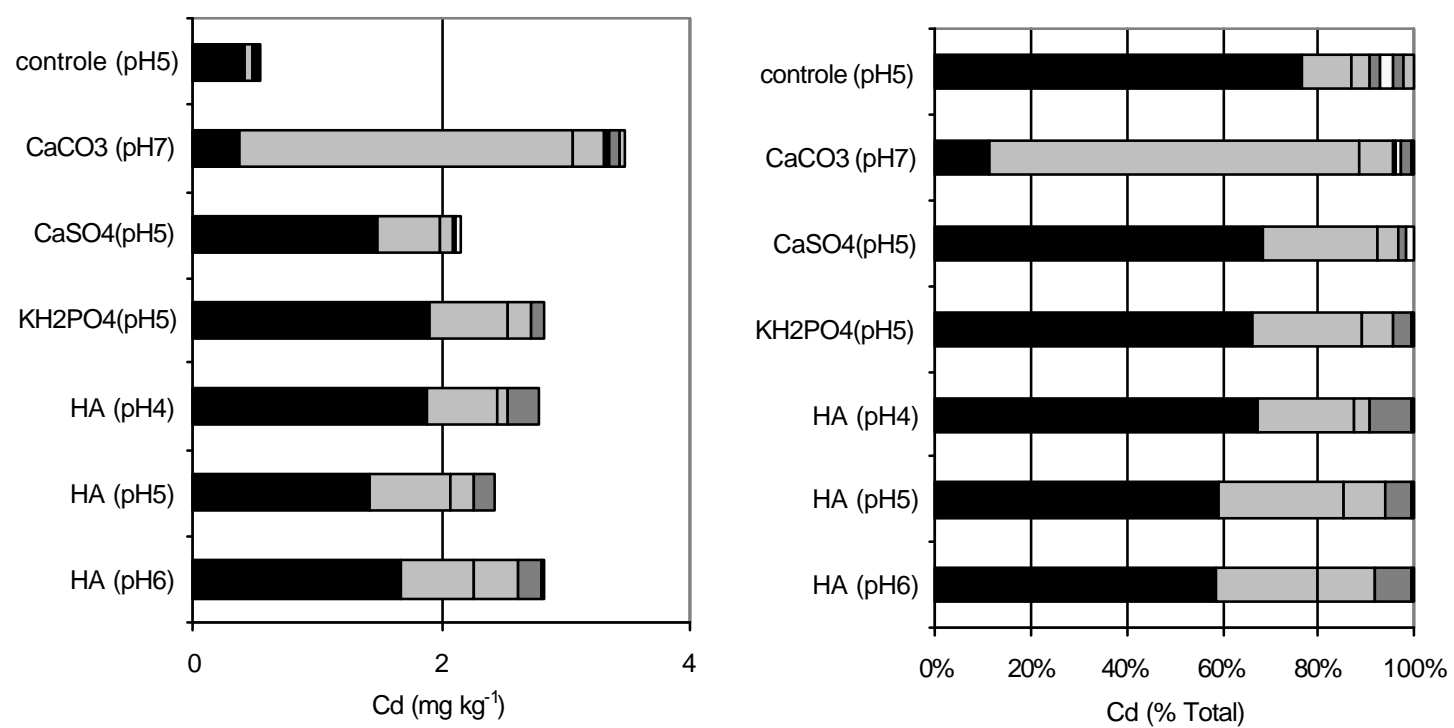

Figura 28 - Distribuição de Cd nas amostras de terra.

=Troc. $\square=$ =Superf.Ox. $\square$ = MO $\square=$ Ox.Mn $\square=$ Fe Ox. $\square$ = Fe crist. $\square=$ Res 


\section{Biossólido 1*}
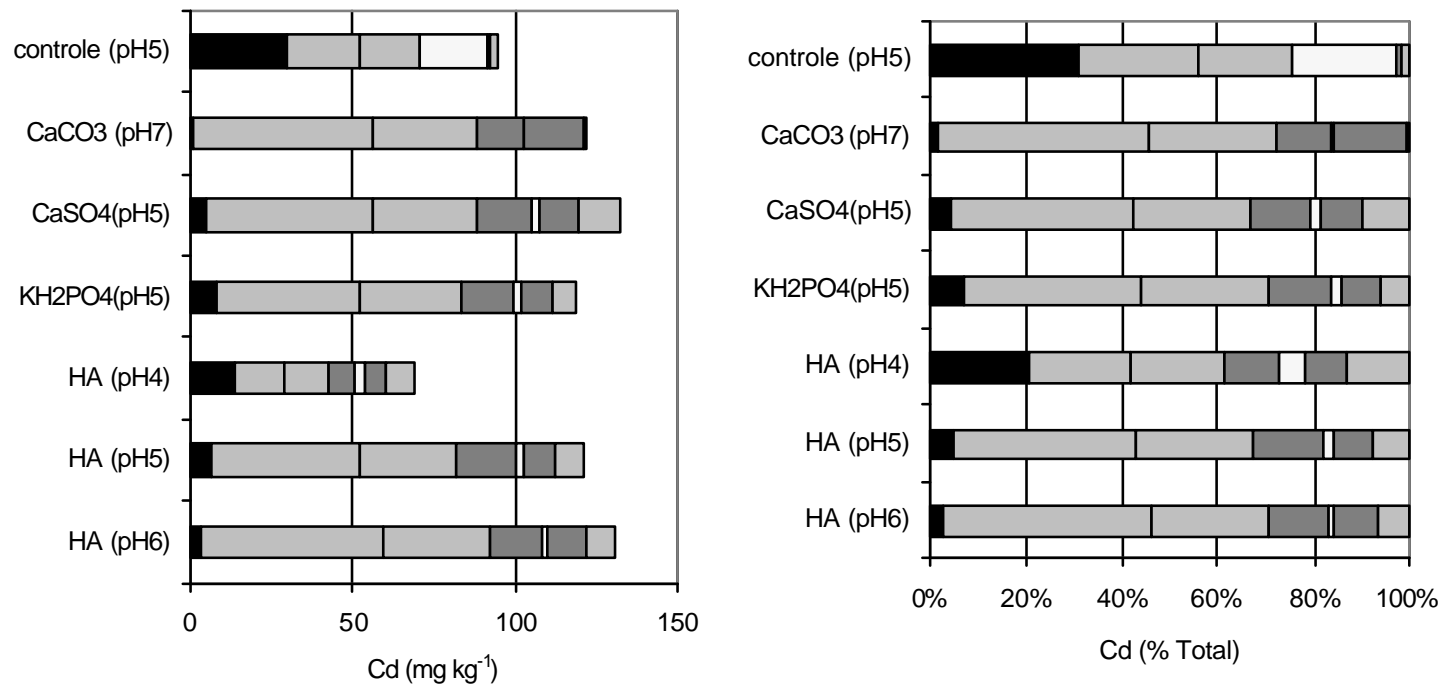

Biossólido 2**
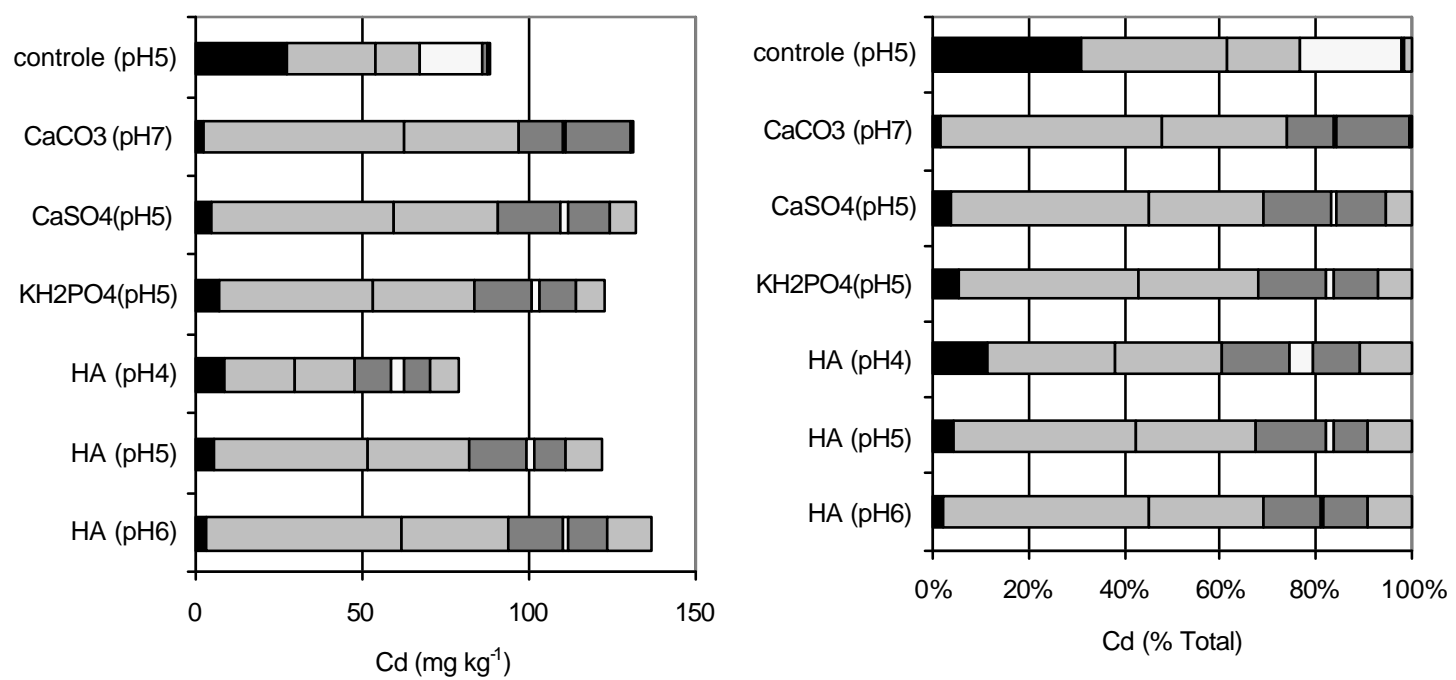

Figura 29 - Distribuição de Cd nas amostras de biossólido. *Biossólido 1 = equilibrado com o LVwf; **Biossólido 2 = equilibrado com o LAd.

=Troc. $\square=$ =Superf.Ox. $\square=$ MO $\square=$ Ox.Mn $\square=$ Fe Ox. $\square$ = Fe crist. $\square=$ Res 
quantidade de $\mathrm{Cd}$ foi disponibilizada do biossólido para solução. Nessas condições, o Cd foi retido nos solos, principalmente, na forma trocável.

No biossólido, embora os valores absolutos de Cd não tenham sido alterados com a adição dos condicionadores, sua distribuição foi afetada sensivelmente (Figura 29). Assim como observado por Fang \& Wong (1999), o tratamento com $\mathrm{CaCO}_{3}$ resultou na redução na porcentagem de $\mathrm{Cd}$ retido na fração trocável. $\mathrm{Na}$ amostra testemunha cerca de 10-12 \% do Cd total estava presente na fração Troc., enquanto na amostra tratada com $\mathrm{CaCO}_{3}$ esse valor foi ao redor para $2 \%$. Apenas na amostra equilibrada com o LVwf que recebeu o tratamento $\mathrm{HA}(\mathrm{pH} 4)$, a quantidade de $\mathrm{Cd}$ na fração Troc. foi superior à amostra testemunha $(12 \%$ do $\mathrm{Cd}$ total na testemunha e $21 \%$ na amostra tratada com HA-pH 4).

\subsection{Conclusões}

Os condicionadores testados foram eficientes na remoção de $\mathrm{Zn}, \mathrm{Cd}$ e, em menor proporção, $\mathrm{Cu}$ da solução. $\mathrm{O}$ pH tem efeito marcante no comportamento desses materiais. $\mathrm{O} \mathrm{CaCO}_{3}$ foi o mais eficiente na imobilização dos metais, seguido da $\mathrm{HA}$ (pH6). Porém, deve-se ressaltar que além da quantidade de metais imobilizados, a escolha de condicionadores para remediação de solos contaminados por metais pesados deve considerar a persistência desse efeito no solo.

Com relação à distribuição dos metais na fase sólida, a fração trocável foi sensivelmente diminuída e os metais ligados à superfície dos óxidos/carbonatos foram aumentados com a introdução dos condicionadores no solo. $\mathrm{O}$ aumento na porcentagem de metais ligados à superfície dos óxidos/carbonatos não garante que esses serão retidos definitivamente, uma vez que essa fração é considerada biodisponível e que fatores ambientais, tais como a acidificação do solo, podem solubilizá-la e os metais podem tornar-se disponíveis novamente. 


\section{CONCLUSÕES GERAIS}

A extração seqüencial de metais foi ferramenta útil para avaliar os efeitos da aplicação de biossólidos e das mudanças no meio, tais como redução no pH, aumento na força iônica e introdução de condicionadores químicos, na distribuição de $\mathrm{Zn}, \mathrm{Cu}$ e $\mathrm{Cd}$ em Latossolos e em biossólidos. Em pHs mais elevados, a solubilização do biossólido e disponibilização dos metais para solução foi reduzida. Quando aplicados via biossólido, os metais em solução encontram-se, principalmente, na forma de íons-livres. $\mathrm{O}$ pH inicial do solo deve ser levado em conta em áreas que recebem resíduos contendo metais pesados, uma vez que a disponibilização desses elementos pode ser favorecida em meios ácidos.

Ao contrário do $\mathrm{Zn}$ e do $\mathrm{Cd}$, a distribuição de $\mathrm{Cu}$ nas amostras de terra tratadas com biossólido foi semelhante às amostras testemunha. A redução no $\mathrm{pH}$ da solução promoveu maior mobilização dos metais na fração trocável. Esse efeito foi mais acentuado para $\mathrm{Cu}$ do que para $\mathrm{Zn}$ e $\mathrm{Cd}$, o que sugere que os mecanismos nos quais esses elementos são retidos nos solos e no biossólido são diferenciados dependendo do metal. Embora os condicionadores químicos de solo reduzam as quantidades de metais disponíveis, sua eficiência depende do $\mathrm{pH}$ da solução. 


\section{REFERÊNCIAS BIBLIOGRÁFICAS}

ABD-ELFATTHAT, A.; WADA, K. Adsorption of lead, copper, zinc, cobalt and cadmium by soils that differ in cation exchange materials. Journal of Soil Science, v.32, p.271-284, 1981.

AHNSTROM, Z.S.; PARKER, D.R. Development and assessment of a sequential extraction procedure for the fractionation of soil cadmium. Soil Science Society of America Journal, v.63, p.1650-1658, 1999.

AKHTER, M.S. Trace metal analysis of sewage sludge and soils in Bahrain. Water, Air and Soil Pollution, v. 51, p.147-152, 1990.

ALLOWAY, B.J. Heavy metals in soils. New York: Wiley, 1990. 339p.

AMACHER, M.C. Determination of ionic activities in soil solutions and suspensions: principal limitations. Soil Science Society of America Journal, v. 48, p.519-524, 1984.

ARUNACHALAM, J.; EMONS, H.; KRASNODEBSKA, B.; MOHL, C. Sequential extraction studies on homogenized forest soil samples. The Science of the Total Environment, v. 181, p.147-159, 1996. 
BAKER, D.E.; AMACHER, M.C.; DOTY, W.T. Monitoring sewage sludge, soils and crops for zinc and cadmium. In: LOEHR, R.C. (Ed.). Land as a waste management alternative. Ann Arbor: Ann Arbor Scientific, 1977. p.261-281.

BARROW, N.J. Reactions of anions and cations with variable-charge soils. Advances in Agronomy, v.38, p.183-229, 1985.

BARROW, N.J.; BOWDEN, J.W.; POSNER, A.M.; QUIRK, J.P. Describing the adsorption of copper, zinc and lead on a variable charge mineral surface. Australian Journal of Soil Research, v.19, p.309-321, 1981.

BARRY, G.A.; CHUDEK, P.J.; BEST E.K.; MOODY, P.W. Estimating sludge application rates to land based on heavy metal and phosphorus sorption characteristics of soil. Water Research, v.29, p.2031-2034, 1995.

BENJAMIN, M.M; LECKIE, J.O. Multiple-site adsorption of $\mathrm{Cd}, \mathrm{Cu}, \mathrm{Zn}$, and $\mathrm{Pb}$ on amorphous iron oxyhydroxide. Journal of Colloid and Interface Science, v.79, n.1, p.209-221, 1981.

BERGLUND, S.; DAVIS, R.D.; L'HERMITE, P. Utilization of sewage sludge on land: rates of application and long-term effects of metals. Dordrecht: D. Reidel Publ., 1984. 216p.

BERTON, R.S.; CHANG, A.C.; PAGE, A.L. Metal ion activities in long-term biosolid amended soils. In: INTERNATIONAL CONFERENCE ON THE BIOGHEOCHEMISTRY OF TRACE ELEMENTS, 5., Vienna, 1999. Proceedings. Vienna: International Society for Trace Elements Research, 1999. p. 292-293. 
BIBAK, A. Cobalt, copper and manganese adsorption by aluminum and iron oxides and humic acid. Communications in Soil Science and Plant Analysis, v.25, p.32293239, 1994.

BOISSON, J.; RUTTENS, A.; MENCH, M.; VANGRONSVELD, J. Evaluation of hydroxiapatite as a metal immobilizing soil additive for the remediation of polluted soils. Part 1. Influence of hydroxiapatite on metal exchangeability in soil, plant growth and plant metal accumulation. Environmental Pollution, v. 104, p.225-233, 1999.

BORGGAARD, O.K. Phase identification by selective dissolution techniques. In: STUCKI, J.W.; GOODMAN, B.A.; SCHWERTMANN, U. (Ed.). Iron in soils and clay minerals. Dordrecht: D. Reidel Publ., 1985. p.83-98.

BRADLEY, S.B.; COX. J.J. Heavy metals the Hamps and Manifold Valleys, North Staffordshire, U.K.: Partitioning of metals in floodplain soils. The Science of the Total Environment, v.65, p.135-153, 1987.

BRASIL trata $35 \%$ do esgoto coletado. Revista Brasileira de Saneamento e Meio Ambiente, v.21, n.22, p.30-31, abr./jun.2002.

CAMARGO, O.A.; MONIZ, A.C.; JORGE, J.A.; VALADARES, J.M.A.S. Métodos de análise química, mineralógica e física de solos do IAC. Campinas: IAC, 1986. $94 \mathrm{p}$.

CANDELARIA, L.M.; CHANG, A.C. Cadmium activities, solution speciation, and solid phase distribution of $\mathrm{Cd}$ in cadmium nitrate and sewage sludge-treated soil systems. Soil Science, v. 162, p.722-732, 1997. 
CANDELARIA, L.M.; CHANG, A.C.; AMRHEIN, C. Measuring cadmium ion activities in sludge-amended soil. Soil Science, v. 159, p.162-175, 1995.

CARLSON-EKVALL, C.E.A.; MORRISON, G.M. Metal partitioning and toxicity in sewage sludge. Environmental Technology, v.18, p.489-497, 1997.

CAVALlARO, N.; McBRIDE, M.B. Activities of $\mathrm{Cu}$ and $\mathrm{Cd}$ in soil solutions as affected by pH. Soil Science Society of America Journal, v.44, p.729-732, 1980.

CHANEY, R.L.; RYAN, J.A. Regulating Residual Management Practices. Water Environment Technology, v. 4, p.36-41, 1992.

CHANG, A. C.; HYUN, H; PAGE, .L. Cadmium uptake for swiss chard grown on composted sewage sludge treated field plots: plateau or time bomb?. Journal of Environmental Quality, v.26, p.11-19, 1997.

CHAO, T.T. Selective dissolution of manganese oxides from soils and sediments with acidified hydroxilamine hydrochloride. Soil Science Society of America Journal, v.36, p.764-768, 1972.

CHAO, T.T.; ZHUO, L. Extraction techniques for selective dissolution of amorphous iron oxides from soils and sediments. Soil Science Society of America Journal, v.47, p.225-232, 1983.

COMPANHIA DE TECNOLOGIA DE SANEAMENTO AMBIENTAL. Aplicação de lodos de sistemas de tratamento biológico em áreas agrícolas: critérios para projeto e operação: manual técnico. São Paulo, 1999, 32p. 
COREY, R.B.; HELMKE, P.A.; KEENEY, D.R.; GERLOFF, G.C.; CHECHKAI, R.T. EPA-600-2-87-002. Cincinnati: USEPA, Water Engineering Research Laboratory, 1987. 322p.

CORNELL, R.M.; SCHWERTMANN, U. The iron oxides. Weinheim: VHC Publ., 1996. 573p.

CORNU, S.; NEAL, C.; AMBROSI, J.P.; WHITE HEAD, P.; NEAL, M.; SIGOLO, J.; VACHIER, P. The environment impact of heavy metals from sewage sludge in ferrasols (São Paulo, Brazil). The Science of the Total Environment, v. 271, p.2748, 2001.

DAVRANCHE, M.; BOLLINGER, J.C. Heavy metal desorption from synthesized and natural iron and manganese oxyhydroxides: effect of reductive conditions. Journal of Colloid and Interface Science, v. 227, p.531-539, 2000.

DePINTO, J.V. An experimental apparatus for evaluating kinetics of available phosphorus release from aquatic particulates. Water Research, v.16, p.1065-1070, 1982.

DONER, H.E. Chloride as a factor in mobilities of $\mathrm{Ni}(\mathrm{II}), \mathrm{Cu}(\mathrm{II})$ and $\mathrm{Cd}(\mathrm{II})$ in soil. Soil Science Society of America Journal, v. 42, p.882-885, 1978.

EMPRESA BRASILEIRA DE PESQUISA AGROPECUÁRIA. Sstema brasileiro de classificação de solo. Rio de Janeiro, 1999. 390p.

ESTADOS UNIDOS. Environmental Protection Agency. Standards for the use or disposal of sewage sludge: final rules. Federal Register, v. 59, p. 9248-9404, 1993. 
ESTADOS UNIDOS. Environmental Protection Agency. A plain english guide to the EPA part 503 biosolids rule. Washington: Environmental Protection Agency Office of Wastewater Management, 1994.

ESTADOS UNIDOS. Environmental Protection Agency. Method 3052: microwave assisted acid digestion of siliceous and organically based matrices(compact disc). Washington, 1996.

EVANS, L.J.; SPIERS, G.A.; ZHAO, G. Chemical aspects of heavy metal solubility with reference to sewage sludge amended soils. International Journal of Analytical Chemistry, v.59, p.291-302, 1995.

FANG, M.; WONG, J.W.C. Effects of lime amendment on availability of heavy metals and maturation in sewage sludge composting. Environmental Pollution, v.106, p.83-89, 1997.

FILEP, G. Soil chemistry: processes and constituents. Budapeste: Akadémiai Kiadó, 1999. 330p.

FITCH, A.; HELMKE, P. Donan equilibrium/graphite furnace atomic absorption estimates of soil extract complexation capacities. Analytica Chimica Acta, v. 61, p.1295-1298, 1989.

FORBES, E.A.; POSNER, A.M.; QUIRK, J.P. The specific adsorption of divalent Cd, $\mathrm{Co}, \mathrm{Cu}, \mathrm{Pb}$ and $\mathrm{Zn}$ on goethite. Journal of Soil Science, v.27, p.154-166, 1976.

FORSTNER, U. Metal speciation- General concepts and application. International Journal of Environmental Analytical Chemistry, v. 51, p.5-23, 1993 
FOTOVAT, A.; NAIDU, R. Changes in composition of soil aqueous phase influence chemistry of indigenous heavy metals in alkaline sodic and acidic soils. Geoderma, v.84, p.213-234, 1998.

FUJII, R.; HENDRICKSON, L.L.; COREY,R.B. Ionic activities of trace metals in sludge-amended soils. Science Total Environment, v.28, p. 179-190, 1983.

GARDINER, J. The chemistry of cadmium in natural water -I . A study of cadmium complex formation using the cadmium specific - ion electrode. Water Research, v.8, p.23-30, 1974.

GE, Y.; MURRAY, P.; HENDERSHOT, W.H. Trace metal speciation and bioavailability in urban soils. Environmental Pollution, v.107, p.137-144, 2000.

GILKES, R.J.; McKENZIE, R.M. Geochemistry and mineralogy of manganese in soils. In: GRAHAM, R.D.; HANNAM, R.J.; UREN, N.C. (Ed.). Manganese in soils and plants. Dordrecht: Kluwer Academic, 1988. p.23-35.

HAMON, R.E.; McLAUGHLIN, M.J.; COZENS, G. Mechanisms of attenuation of metal availability in situ remediation treatments. Environmental Science Technology, v.36, p.3991-3996, 2002.

HARMSEN, K.; VLEK, P.L.G. The chemistry of micronutrients cations in a group of loessial grassland soils of New Zealand. Geoderma, v.83, p.53-62, 1985.

HIRSCH, D.; BONIN, A. Cadmium speciation in soil solutions. Journal of Environmental Quality, v. 19, p. 366-372, 1990. 
HOELGREM, G.G.S.; MEYER, M.W.; CHANEY, R.L.; DANIELS, R.B. Cd, Pb, Zn, $\mathrm{Cu}$ and $\mathrm{Ni}$ in agricultural soils of the United States of America. Journal of Environmental Quality, v.22, p.335-348, 1993.

IMPELLITTERI, C.A.; ALLEN, H.E.; YIN, Y.; YOU, S.J.; SAXE, J.K. Soil properties controlling metal partitioning. In: SELIM, H.M.; SPARKS, D.L. (Ed.) Heavy metals release in soils. Lewis Publishers, 2001. p.149-165.

IYENGAR, S.S.; MARTENS, D.C.; MILLER, W.P. Distribution and plant availability of soil zinc fractions. Soil Science Society of America Journal, v. 45, p.735-739, 1981.

JEANROY, E.; RAJOT, J.L.; PILLON, P.; HERBILlON, A.J. Differential dissolution of hematite and goethite in dithionite and its implication on soil yellowing. Geoderma, v.50, p.79-94, 1991.

JEFFERY, J.J.; UREN, N.C. Copper and zinc species in the solution and the effects of soil pH. Australian Journal of Soil Research, v.21, p.479-488, 1983

JI, G.L.; LI, H.Y. Electrostatic adsorption of cations. In: YU, T.R. (Ed.). Chemistry of variable charge soils. New York: Oxford University Press, 1997. p.64-111.

JING, J.; LOGAN, T.J. Effects of sewage sludge cadmium concentration on chemical extractability and plant uptake. Journal of Environmental Quality, v. 21, p.73-81, 1992.

KABATA-PENDIAS, A.; PENDIAS, H. Trace elements in soils and plants. Boca Raton: CRR Press, 1987. 315p. 
KALBASI, M.; RACZ, G.J. Association of zinc with oxides of iron and aluminum in some Manitoba soils. Canadian Journal of Soil Science, v. 58, p.61-68, 1978.

KALBASI, M.; RACZ, G.J.; LOEWEN-RUDGERS, L.A. Mechanism of zinc adsorption by iron and aluminum oxides. Soil Science, v. 125, p.146-150, 1978.

KARAPANAGIOTIS, N.; STERRITT, R.; LESTER, J.N. Heavy metals complexation in sludge-amended soil. The role of organic matter in metal retention. Environmental Technology, v.12, p.1107-1116, 1991.

KELLER, A., STEIGER, B.V; VAN DER ZEE, S.E.A.T.M.; SCHULIN, R. A stochastic empirical model for regional heavy-metal balances in agroecosystems. Journal of Environmental Quality, v.30, p.1976-1989, 2001.

KHEBOIAN, C.; BEAUR, C.F. Accuracy of selective extraction procedure for metal separation in model aquatic sediments. Analytica Chimica Acta, v. 59, p.1417$1423,1987$.

KIEKENS, L. Behaviour of heavy metals in soils. In: BERGLUND, S.; DAVIS, R.D.; L'HERMITE, P (Ed.). Utilization of sewage sludge on land: rates of application and long-term effects of metals. Dordrecht: D. Reidel Publ., 1983. p.126-134.

KOECKRITZ, T.; THOMING, J.; GLEYZES, C.; ODEGARD, K.E. Simplification of a sequential extraction scheme to determine the mobilisable heavy metal pool in soils. Acta Hydrochimica Hydrobiology, v. 29, n.4, p.197-205, 2001.

KRASNODEBSKA-OSTREGA， B.; EMONS， H.; GOLIMOWSKI，J. Selective leaching of elements associated with $\mathrm{Mn}-\mathrm{Fe}$ oxides in Forest soil, and comparison of two sequential extraction methods. Frenesius Journal Analytical Chemistry., v.371, p.385-390, 2001. 
KRISHNAMURTI, G.S.R.; NAIDU, R. Solid-solution speciation and phytoavailability of copper and zinc in soils. Environmental Science Technology, v.36, p.26452651, 2002.

KUO, S.; HEILMAN, P.E.; BAKER, A.S. Distribution and forms of copper, zinc, cadmium, iron and manganese in soils near a copper smelter. Soil Science, v.135, p.101-109, 1983.

LINDSAY, W.L. Chemical equilibria in soils. New York: Wiley, 1979. 450p.

LOMBI, E.; GERZABEK, M.H. Determination of mobile heavy metal fraction in soil: result of a plot experiment with sewage sludge. Communications in Soil Science and Plant Analysis, v.29, p.2545-2556, 1998.

LÓPEZ-MOSQUERA, M.E; MOIRÓN, C.; CARRAL, E. Use of dairy-industry sludge as fetiliser for grasslands in northwest Spain: heavy metal level in the soil and plant. Resource, Conservation and Recycling, v.30, p.95-109, 2000.

LÓPES-SÁNCHES, J.F.; RUBIO, R.; RAURET, G. Comparison of two sequential extraction procedures for trace metal partitioning in sediments. Journal of Environmental Analytical Chemistry, v.51, p.113-121, 1993.

LORENZ, S.E.; HAMON, R.E.; HOLM, P.E.; DOMINGUES, H.C.; SEQUEIRA, E.M. Cadmium and zinc in plants and soil solutions from contaminated soils. Plant and Soil, v. 189, p.21-31, 1997.

LUM, K.R.; BETTERIDGE, J.S.; McDONALD, R.R. The potential availability of P, $\mathrm{Al}, \mathrm{Cd}, \mathrm{Co}, \mathrm{Cr}, \mathrm{Cu}, \mathrm{Fe}, \mathrm{Mn}, \mathrm{Ni}, \mathrm{Pb}$ and $\mathrm{Zn}$ in urban particulate matter. Science and Technology Letters, v.3, p57-62, 1982. 
MA, Q.Y.; TRAINA, S.J.; LOGAN, T.J. In situ lead immobilization by apatite. Environmental Science and Technology, v. 27, p.1803-1810, 1993.

MA, Q.Y.; LOGAN, T.J.; TRAINA, S.J. Lead immobilization from aqueous solutions and contaminated soils using phosphate rocks. Environmental Science Technology, v.29, p.118-1126, 1995.

MA, Q.Y.; TRAINA, S.J.; LOGAN, T.J.; RYAN, J.A. Effects of aqueous Al, Cd, Cu, $\mathrm{Fe}(\mathrm{II}), \mathrm{Ni}$ and $\mathrm{Zn}$ on $\mathrm{Pb}$ immobilization by hyfroxiapatite. Environmental Science and Technology, v. 28, p.1219-1228, 1994.

MA, Y.B.; UREN, N.C. Transformations of heavy metals added to soil application of a new sequential extraction procedure. Geoderma, v. 84, p.157-168, 1998.

MAISONNAVE, V.; MONTREJAUD-VIGNOLES, M.; BONNIN, C.; REVEL, J.C.; VIGNOLES, C. The influence of biosolids treatment files on the mobility of metal trace elements. Water Science and Technology, v.44, p.381-387, 2001.

MARTINÉZ, C.E.; McBRIDE, M.B. Solubility of $\mathrm{Cd}, \mathrm{Cu}, \mathrm{Pb}$ and $\mathrm{Zn}$ in aged coprecipitates with amorphous iron hydroxides. Environmental Science Technology, v.32, p.743-748, 1998.

MATTIGOD, S.V.; PAGE, A.L. Assessment of metal pollution in soil. In: THORTON, I. (Ed.). Applied environmental geochemistry. New York: Academic Press, 1983. cap.12, p.355-394.

MATTIGOD, S.V.; SPOSITO, G. Chemical modeling of trace metal equilibria in contaminated soil solutions using the computer program GEOCHEM. In: JENNE, 
E.A. (Ed.). Chemical modeling in aqueous systems. Washington: American Chemical Society, 1979. p.837-856. (ACS Symposium Series, 9).

MATTIGOD, S.V.; SPOSITO, G.; PAGE, A.L. Factors affecting the solubilities of trace metals in soils. In: DOWDY, R.H.; RYAN, J.A.; VOLK, V.V.; BAKER, D.E. (Ed.). Chemistry in the soil environment. Wiscosin: American Society of Agronomy; American Soil Science Society, 1981. p.203-221. (Special Publication, 40).

McBRIDE, M.B. Toxic metal accumulation from agricultural use of sludge: are USEPA regulations protective?. Journal of Environmental Quality, v. 24, p. 5-18, 1995.

McBRIDE, M.B. Growing food crops on sludge-amended soils: problems with U.S. environmental protection agency method of estimating toxic metal transfer. Environmental toxicology and chemistry, v.17, p.2274-2281, 1998.

McBRIDE, M.B.; BLASIAK, J.J. Zinc and copper solubility as a function of $\mathrm{pH}$ in an Acid soil. Soil Science Society of America Journal, v. 43, p.866-870, 1979.

McBRIDE, M.B.; SPIERS, G. Trace element content of selected fertilizes and dairy manures determined by ICP-MS. Communications in Soil and Plant Analysis, v.32, p.139-156, 2001.

McBRIDE, M.B.; RICHARDS, B.K.; STEENHUIS, T.; RUSSO, J.J.; SAUVE, S. Mobility and solubility of toxic metals and nutrients in soil fifteen years after sludge application. Soil Science, v.162, n.7, p.487-500, 1997.

McGRATH, S.P. Long-term studies of metal transfers following application of sewage sludge. In: COUGHTREY, P.J.; MARTIN, M.H.; UNSWWORTH, M.H. (Ed.). 
Pollution transport and fate in ecosystems. Oxford: Blackwell Scientific, 1987. p.301-317. (British Ecological Society. Special Publication, 6).

McLAREN, R.G.; CRAWFORD, D.V. Studies on soil copper. 1- The fractionation of copper in soils. Journal of Soil Science, v.24, p.172-181, 1973.

MEHA, O.P.; JACKSON, M.L. Iron oxide removal from soils and clays by a dithionitecitrate system buffered with sodium bicarbonate. In: National Conference on Clays and Clay Minerals, 7., Washington, 1960. Proceedings. Washington: National Academy Science and Natural Research,1960. p.317-327.

MOOLENAAR, S.W.; BELTRAMI, P. Heavy metals in the environment. Heavy metal blances of an Italian soil as affect by sewage sludge and Bordeaux misture applications. Journal of Environmental Quality, v.27, p.828-835, 1998.

MORERA, M.T.; ECHEVERRÍA, J.C.; MAZKIARÁN, C.; GARRIDO, J.J. Isotherms and sequential extraction foe evaluating sorption and distribution of heavy metals in soils. Environmental Pollution, v. 113, p.135-144, 2001.

MSAKY, J.J.; CALVET, R. Adsorption behavior of copper and zinc in soils: influence of $\mathrm{pH}$ on adsorption characteristics. Soil Science, v.150, p.513-522, 1990.

NORVELL, W.A. Equilibria of metal chelates in soil solution. In: MORTVEDT, J.J.; GIORDANO, P. M.; LINDSAY, W. L.(Ed.). Micronutrients in agriculture. Madison: Soil Science Society America , 1971. p. 115-138.

NORVELL, W.A. Inorganic reaction of manganese in soils. In: GRAHAM, R.D.; HANNAM, R.J.; UREN, N.C. (Ed.). Manganese in soils and plants. Boston: Kluwer Academic, 1988. p.37-58. 
OBERLE, S.L.; KEENEY, D.R. Interactions of sewage sludge with soil-crop-water system. In: CLAPP, C.E.; LARSON, W.E.; DOWDY, R.H. (Ed.). Sewage sludge: land utilization and the environment. Madison: Soil Science Society of America, 1994. p.17-25.

OBRADOR, A.; RICO, M.I.; MINGOT, J.I.; ALVAREZ, J.M. Metal mobility and potential bioavailability in organic matter-rich soil-sludge mixtures: effect of soil type and contact time. The Science of the Total Environment, v. 206, p.117-126, 1997.

OORSCHOT, I.H.M.; DEKKERS, M.J. Dissolution of fine-grained magnetite and maghemite in citrate-bicarbonate-dithionite extraction method. Earth and Planetary Science Letters, v.167, p.283-295, 1999.

PALAZZO, A.J.; REYNOLDS, C.M. Long-term changes in soil and plant metal concentrations in an acid dredge disposal site receiving sewage sludge. Water, Air and Soil Pollution, v.57, p.839-848, 1991.

PARKER, D.R.; NORVELL, W.A.; CHANEY, R.L. GEOCHEM-PC: A chemical speciation program for IBM and compatible personal computers. In: LIPPERT, R.H. (Ed.). Soil chemical equilibria and reaction models. Madison: Soil Science Society America, 1995. p.253-169. (Special Publication, 42).

PEACOCK, S.; RIMMER, D.L. The suitability of an iron-rich gypsum by product as a soil amendment. Journal of Environmental Quality, v. 29, 1969-1975, 2000. 
PEARSON, M.S.; MAENPAA, K.; PIERZYNSKI, G.M.; LIDY, M.J. Effects of soil amendments on the availability of lead, zinc, and cadmium to earthworms. Journal of Environmental Quality, v.29, p.1611-1617, 2000.

PERCIVAL, H.J.; SPEIR, T.W.; PARSHOTAM, A. Soil solution chemistry of contrasting soils amended with heavy metals. Australian Journal of Soil Research, v.37, p.993-1004, 1999.

PETRUZZELLI, G.; GUIDI, G.; LUBRANO, L. Ionic strength effect on heavy metal adsorption by soil. Communications in Soil Science and Plant Analysis, v.16, p.971-986, 1985.

PETRUZZELLI, G.; OTTAVIANI, M.; LUBRANO, L.; VESCHETTI, E. Characterization of heavy metal mobile species in sewage sludge for agricultural utilization. Agrochimica, v.38, p.277-284, 1994.

PINHEIRO-DICK, D.; SCHWERTMANN, U. Microagregates from Oxisols and Inceptisols: dispersion through selective dissolutions and physicochemical treatments. Geoderma, v.74, p.49-63, 1996.

ROSS, S.M. retention, transformation and mobility of toxic metals in soil-plant systems. In: ROSS, S.M. (Ed.). Toxic metals in soil-plant system. Chichester: John Wiley, 1994. p.63-152.

RYAN, J.A.; CHANEY, R.L. Development of limits for land application of municipal sewage sludge: risk assessment. In: WORLD CONGRESS OF SOIL SCIENCE, 15., Acapulco, 1994. Transactions. Acapulco: International Society of Soil Science, 1994. v. 3, p. 534-553. 
SALAM, A.K.; HELMKE, P.A. The $\mathrm{pH}$ dependence of free ionic activities and total dissolved concentrations of copper and cadmium in soil solution. Geoderma, v.83, p.281-291, 1998.

SASTRE, I,; VICENTE, M.A.; LOBO, M.C. Behaviour of cadmium and nickel in a soil amended with sewage sludge. Land Degradation and Development, v.12, p.27-33, 2001.

SAUVÉ, S.; NORVELL, W.A.; McBRIDE, M.; HNDERSHOT, W. Speciation and complexation of cadmium in extracted soil solutions. Environmental Science Technology, v.34, p.291-296, 2000.

SCHMIDT, J.P. Understanding phytotoxicity thresholds for trace elements in landapplied sewage-sludge. Journal of Environmental Quality, v.26, p.4-10, 1997.

SCHWERTMANN, U. Die fraktionierte extraction der freien eisenoxyde in boden, ihre mineralogischen formen und ihre entste-hungsweisen, Zeitung Pflanzenernähr Düng Bodenkontrolle, v.84 p.194-204, 1959.

SCHWERTMANN, U. Differezierung der eisenoxide des bodens durch photochemische extraktion mit saurer ammoniumoxalate-lösung Zeitung Pflanzenernähr Düng Bodenkontrolle, v.105, p.194-202, 1964.

SCHWERTMANN, U. The influence of aluminium on iron oxides: IX. Dissolution of Al-goethites in 6M HCl. Clay Minerals, v.19, p.9-19, 1984.

SCHWERTMANN, U. Solubility and dissolution of iron oxides. Plant and Soil, v. 130, p.1-25, 1991. 
SCHWERTMANN, U.; MURAD, E. Effect of $\mathrm{pH}$ on the formation of goethite and hematite from ferrydrite. Clays and Clay Minerals, v.31, p.277-284, 1983.

SHANON, R.D.; WHITE, J.R. The selectivity sequential extraction procedure for the determination of iron hydroxides and iron sulfites in lake sediments. Biogeochemistry, v. 14, p.193-208, 1991.

SHUKLA, U.C.; MITTAL, S.B.; GUPTA, R.K. Zinc adsorption in some soils as affected by exchangeable cations. Soil Science, v.129, p.366-370, 1980.

SHUMAN, L.M. Zinc, manganese and copper in soil fractions. Soil Science, v.127, p.10-17, 1979.

SHUMAN, L.M. Separating soil iron- and manganese-oxide fractions for microelement analysis. Soil Science Society of America Journal, v.46, p.1099-1102, 1982.

SHUMAN, L.M. Fractionation method for soil microelements. Soil Science, v.140, p.11-22, 1985.

SHUMAN, L.M. Effect of liming on the distribution of manganese copper, iron, and zinc among soil fractions. Soil Science Society of America Journal, v.50, p.1236$1240,1986$.

SHUMAN, L.M. Effect of phosphorus level on extractable micronutrients and their distribution among soil fractions. Soil Science of America Journal, v.52, p.136$141,1988$.

SHUMAN, L.M. Chemical forms of micronutrients in soils. In : MICKELSON, S.H. (Ed.), Micronutrients in agriculture. 2.ed. Madison: Soil Science Society of America, 1991. p. 113-183. 
SIDHU, P.S.; GILKES, R.J.; CORNELL, R.M.; POSNER, A.M.; QUIRK, J.P. Dissolution of iron oxides and oxyhydroxides in hydrochloric and perchloric acids. Clay and Clays Minerals, v.29, p.269-276, 1981.

SILVEIRA, M.L.A.; ALLEONI, L.R.F.; CASAGRANDE, J.C.; CAMARGO, O.A. Energia livre da reação de adsorção de cobre em latossolos ácricos. Scientia Agricola, v.56, p.1117-1122, 1999.

SILVEIRA, M.L.A.; ALLEONI, L.R.F.; CASAGRANDE, J.C.; CAMARGO, O.A. Copper adsorption in oxidic soils after removal of organic matter and iron oxides. Communications in Soil Science and Plant Analysis, v.33, p.3581-3592, 2002.

SIMS, J.T. Soil $\mathrm{pH}$ effects on the distribution and plant availability of manganese, copper and zinc. Soil Science Society of America Journal, v. 50, p.367-373, 1986.

SINGH, B.; GILKES, R.J. Properties and distribution of iron oxides and their association with minor elements in the soils of South-Western Australia. Journal of Soil Science, v.43, p.77-98, 1992.

SINGH, M. Retention of added copper by two soils as affected by organic matter, $\mathrm{CaCO}_{3}$ and exchangeable ions. Geoderma, v.5, p.219-227, 1971.

SMITH, S.R. Agricultural recycling of sewage sludge and the environment. London: CAB International, 1996. cap.5, p.59-79: Factors influencing the bioavalability of PTEs to crop plants.

SMITH, S.T. Effect of soil $\mathrm{pH}$ on availability to crops of metals in sewage sludgetreated soils. I. Nickel, copper and zinc uptake and toxicity to ryegrass. Environmental Pollution, v.85, p.321-327, 1994a. 
SMITH, S.T. Effect of soil $\mathrm{pH}$ on availability to crops of metals in sewage sludgetreated soils. II. Cadmium uptake by crops and implications for human dietary intake. Environmental Pollution, v.86, p.5-13, 1994b.

SPARKS, D.L. Environmental soil chemistry. San Diego: Academic Press, 1995. $267 \mathrm{p}$.

SPOSITO, G. Solubility equilibria in soil solutions. In: SPOSITO, G. (Ed.). The thermodynamics of soil solution. New York: Oxford Clarendon Press, 1981. p.66101.

SPOSITO, G. The chemical forms of trace metals in soils. In: THORNTON, I. (Ed.). Applied environmental geochemistry. London: Academic Press, 1983. p.123-170. (Geology Series).

SPOSITO, G. The chemistry of soils. New York: Oxford University Press, 1989. 277p.

SPOSITO, G. Chemical equilibria and kinetics in soils. New York: Oxford University Press, 1994. 288p.

SPOSITO, G.; COVES, J. A computer program for the calculation of chemical speciation in soils. Riverside: University of California, The Kearney Foundation of Soil Science, 1988. 92p.

SPOSITO, G.; MATTIGOD, S.V. A computer program for the calculation of chemical equilibria in soil solutions and other natural water systems. Riverside: University of California, The Kearney Foundation of Soil Science, 1980. 92p. 
SPOSITO, G.; BINGHAM, F.T.; YADAV, S.S.; UNOUYE, C.A. Trace metal complexation by fulvic acid extracted from sewage sludge: II Development of chemical models. Soil Science Society of America Journal, v. 46, p.51-56, 1982a.

SPOSITO, G.; LUND, L.J.; CHANG, A.C. Trace metal chemistry in arid-zone field soils amended with sewage sludge: I. Fractionation of $\mathrm{Ni}, \mathrm{Cu}, \mathrm{Zn}, \mathrm{Cd}$, and $\mathrm{Pb}$ in solid phases. Soil Science Society of America Journal, v. 46, p.260-264, 1982 b.

TAMM, O. Eine methode zur bestimmung der anorganischen komponenten des gelkomplexes in Boden, Medd. Statens Skogsförsöksanstalt, v. 19, p. 385-404, 1922.

TAYLOR, M.D.; PERCIVAL, H.J. Cadmium in soil solutions from a transect of soils away from a fertilizer bin. Environmental Pollution, v.113, p.35-40, 2001.

TEMMINGHOFF, E.J.M.; VAN DER ZEE, S.E.A.T.M.; DE HAAN, F.A.M. Speciation and calcium competition effects on cadmium sorption by sandy soil at various pHs. European Journal of Soil Science, v. 46, p.649-655, 1995.

TESSIER, A.; CAMPBELL, P.G.C.; BISSON, M. Sequential extraction procedure for the speciation of particulate trace metals. Analytical Chemistry, v.51, p.844-851, 1979.

TIPPING, E.; HETHERINGTON, N.B.; HILTON, J. Artifacts in the use of selective chemical extraction to determine distributions of metals between oxides of manganese and iron. Analytical Chemistry, v.57, 1944-1946, 1985.

TISDALE, S.L.; NELSON, W.L.; BEATON, J.D.; HAVLIN, J.L. Soil fertility and fertilizers. New York: MacMillan, 1993, p.176-229. 
TOMLIN, A.D.; PROTZ, R.; MARTIN, R.R.; McCABE D.C. Relationships amongst organic matter content, heavy metal concentrations, earthworm activity and soil microfabric on a sewage sludge disposal site. Geoderma, v.57, p.89-103, 1993.

TSADILAS, C.D.; MATSI, T.; BARBAYIANNIS, N.; DIMOYIANNIS, D. Influence of sewage sludge application on soil properties and on the distribution and availability of heavy metal fractions. Communications in Soil Science and Plant Analysis, v.26, p.2603-2619, 1995.

WEGGLER-BEATON, K.; McLAUGHLIN, M.J.; GRAHAM, R.D. Salinity increases cadmium uptake by wheat and Swiss chard from soil amended with biosolids. Australian Journal of Soil Research, v. 38, p.37-45, 2000.

WONG, J.W.; FANG, M. Effects of lime addition on sewage sludge composting process. Water Research, v.34, p.3691-3698, 2000.

WU, Q.; HENDERSHOT, W.H.; MARSHALL, W.D.; GE, Y. Speciation of cadmium, copper, lead, and zinc in contaminated soils. Communications in Soil Science and Plant Analysis, v.31, p.1129-1144, 2000.

XU, Y.; SCHWARTZ, F.W. Sorption of $\mathrm{Zn}^{2+}$ and $\mathrm{Cd}^{2+}$ on hydroxyapatite surfaces. Environmental Science Technology, v.28, p.1472-1480, 1994.

YIN, Y.; IMPELLITERI, C.A.; YOU, S.J.; ALLEN, H.E. The importance of organic matter distribution and extract soil:solution on the desorption of heavy metals from soils. The Science of the Total Environment, v.287, p.107-119, 2002. 
YU, T.R.; SUN, H.Y.; ZHANG, H. Specific adsorption of cations. In: YU, T.R. (Ed.). Chemistry of variable charge soils. New York: Oxford University Press, 1997, p.140-174.

ZHANG, T.; SHAN, X.; FULIANG, L. Comparison of two sequential extraction procedures for speciation analysis of metals in soils and plant availability. Communications in Soil Science and Plant Analysis, v. 29, p. 1023-1034, 1998.

ZHU, B.; ALVA, A.K. Differential adsorption of trace metals by soils as influenced by exchangeable cations and ionic strength. Soil Science, v.155, p.61-66, 1993. 